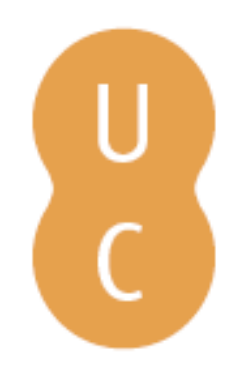

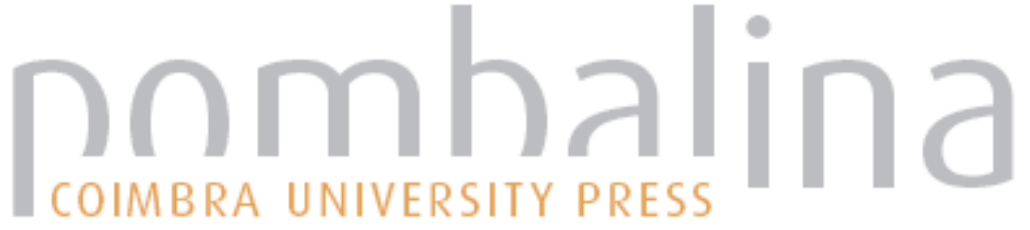

Fraude e plágio na Universidade: a urgência de uma cultura de integridade no Ensino Superior

\begin{tabular}{|c|c|}
\hline Autor(es): & $\begin{array}{l}\text { Almeida, Filipe, ed. lit;; Seixas, Ana, ed. lit.; Gama, Paulo, ed. lit.; } \\
\text { Peixoto, Paulo, ed. lit.; Esteves, Denise, ed. lit. }\end{array}$ \\
\hline Publicado por: & Imprensa da Universidade de Coimbra \\
\hline $\begin{array}{l}\text { URL } \\
\text { persistente: }\end{array}$ & URI:http://hdl.handle.net/10316.2/38804 \\
\hline DOI: & DOI:http://dx.doi.org/10.14195/978-989-26-1123-5 \\
\hline Accessed : & 16-Dec-2016 15:40:36 \\
\hline
\end{tabular}

A navegação consulta e descarregamento dos títulos inseridos nas Bibliotecas Digitais UC Digitalis, UC Pombalina e UC Impactum, pressupõem a aceitação plena e sem reservas dos Termos e Condições de Uso destas Bibliotecas Digitais, disponíveis em https://digitalis.uc.pt/pt-pt/termos.

Conforme exposto nos referidos Termos e Condições de Uso, o descarregamento de títulos de acesso restrito requer uma licença válida de autorização devendo o utilizador aceder ao(s) documento(s) a partir de um endereço de IP da instituição detentora da supramencionada licença.

Ao utilizador é apenas permitido o descarregamento para uso pessoal, pelo que o emprego do(s) título(s) descarregado(s) para outro fim, designadamente comercial, carece de autorização do respetivo autor ou editor da obra.

Na medida em que todas as obras da UC Digitalis se encontram protegidas pelo Código do Direito de Autor e Direitos Conexos e demais legislação aplicável, toda a cópia, parcial ou total, deste documento, nos casos em que é legalmente admitida, deverá conter ou fazer-se acompanhar por este aviso.

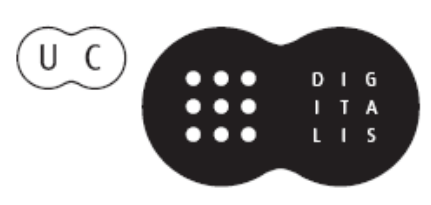


Esta obra junta-se a uma outra (também editada pela IUC) para ambas se constituírem como duas faces de uma mesma moeda. Tendo um alcance distinto, as duas resultam de um mesmo projeto de investigação centrado na temática da fraude académica e complementam-se mutuamente. Nesta obra reunimos alguns dos textos que sustentaram as intervenções feitas pelos seus autores no colóquio final do projeto, que teve lugar na Faculdade de Economia da Universidade de Coimbra a 8 e 9 de maio de 2014. Trata-se de autores cujas reflexões foram muito importantes para a conceção e o desenvolvimento do projeto. Alguns deles assumiram a função de consultores externos e o seu contributo estende-se muito para lá das reflexões que aqui deixam escritas.

Esta é uma obra eminentemente teórica, ao contrário da outra (que sistematiza os resultados empíricos, alcançados no âmbito do projeto, relativos à fraude académica cometida pelos estudantes em Portugal). A fraude académica e as suas variantes e dimensões; as suas causas e consequências; os obstáculos e as soluções inerentes ao seu enfrentamento; os atores envolvidos e os contextos da sua ocorrência são, entre outros, alvos de conceptualização, de escrutínio e de discussão. Discussão que aqui fica também expressa pela publicação, em tom coloquial, dos debates ocorridos entre os participantes ao longo dos dois dias do colóquio.

Este livro resulta do projeto de investigação "A ética dos alunos e a tolerância de professores e instituições perante a fraude académica no ensino superior" (PTDC/ CPE-CED/115915/2009 - FCOMP-01-0124-FEDER-014424), financiado, através da FCT - Fundação para a Ciência e a Tecnologia, no âmbito do Programa Operacional Temático Fatores de Competitividade (COMPETE) e comparticipado pelo Fundo Comunitário Europeu FEDER. 
悬

$\frac{\mathrm{I}}{\mathrm{U}}$ 
EDIÇÃo

Imprensa da Universidade de Coimbra

Email: imprensa@uc.pt

URL: http//www.uc.pt/imprensa_uc

Vendas online: http://livrariadaimprensa.uc.pt

\author{
COORDENAĈ̣̃O EDITORIAL \\ Imprensa da Universidade de Coimbra
}

ConceÇão gráfica

António Barros

INFOGRAFIA

Carlos Costa

REVISÃo

Maria da Graça Pericão

EXECUÇ̃̃o GRÁFICA

Simões \& Linhares, Lda

ISBN

978-989-26-1122-8

ISBN DigItAL

978-989-26-1123-5

DOI

http://dx.doi.org/10.14195/978-989-26-1123-5

\author{
Depósito legal
}

$406347 / 16$ 


\section{FRAUDE E PLÁGIO NA UNIVERSIDADE}

A URGÊNCIA DE UMA CULTURA DE

INTEGRIDADE NO ENSINO SUPERIOR

FILIPE ALMEIDA

ANA SEIXAS

PAULO GAMA

PAULO PEIXOTO

DENISE ESTEVES

COORDENAÇÃO

IMPRENSA DA UNIVERSIDADE DE COIMBRA 
(Página deixada propositadamente em branco.) 


\section{SUMÁRIO}

1. UMA CULTURA DE INTEGRIDADE PARA O ENSINO SUPERIOR 11

Filipe Almeida, Paulo Peixoto, Ana Seixas, Denise Esteves e Paulo Gama

1.1. Referências bibliográficas .26

2. ÉTICA E FRAUDE NO ENSINO SUPERIOR: À PROCURA

DE NOVOS MODOS DE REGULAÇÃO.

Jacques Hallak

2.1. Ética e fraude no ensino superior .33

2.2. A fraude académica participa na regulação do ensino superior ... 34

2.2.1. As fraudes nos exames .35

2.2.2. O plágio 37

2.2.3. A obtenção de títulos ou de validações

através de meios ilegais 38

2.2.4. As falsificações (irregularidades nas inscrições, produção de falsos documentos administrativos). .39

2.3. As políticas de luta contra a fraude académica: management e ética

2.3.1. Prevenção através de informação e sensibilização:

o papel central da ética .41

2.3.2. Vigilância, deteção das fraudes: gerir da melhor forma os ficheiros das universidades e as provas de exames 
2.4 Sanções e penalidades: "um pau de dois bicos?"

2.5. Regular o funcionamento ou adaptar as finalidades

e os métodos de ensino superior? Pistas para a reflexão .50

2.6. Referências bibliográficas. .56

\section{PARA QUE NÃO SE CONFUNDA A GESTÃo DO PLÁGIO}

ESTUDANTIL COM QUESTÕES DE ÉTICA, FRAUDE E LUDÍBRIO:

O QUE NOS ENSINA A EXPERIÊNCIA DO ENSINO

SUPERIOR EUROPEU

Jude Carroll

3.1. Introdução 61

3.2. Distinções necessárias.

3.2.1. Distinção entre plágio e ludíbrio

3.2.2. Definição de ludíbrio..... 67

3.2.3. Plágio, ou ludíbrio com recurso ao plágio? .68

3.2.4. As complexidades do mal-entendido .69

3.2.5. Os estudantes que não seguem as normas

depois de compreendidas .71

3.2.6. Identificação dos casos de infração grave .72

3.2.7. Distinção entre ludíbrio e fraude .77

3.3. Guia de boas práticas das políticas e procedimentos

a seguir na gestão do plágio estudantil .78

3.4. Caraterísticas de uma política eficaz de gestão do plágio .80

3.4.1. A gestão do plágio requer uma abordagem de tipo holístico .80

3.5. A gestão do plágio requer que as decisões do foro pedagógico pertençam aos docentes. .83

3.6. A gestão do plágio requer uma utilização hábil das estratégias de deteção .85

3.6.1. A gestão dos casos detetados tem de ser eficiente. .85 
3.6.2. Os procedimentos de gestão dos processos têm de ser justos, coerentes e defensáveis

3.6.3. A gestão do plágio estudantil requer

um arquivo de registos de qualidade

3.6.4. A gestão do plágio deve enquadrar-se

nos procedimentos de gestão da qualidade (GQ)

em vigor na universidade .87

3.7. A adoção de uma abordagem holística: por onde começar? ........87

3.8. Linhas gerais do sistema do academic conduct officer ............. 89

3.9. Conclusão..................................................................94

3.10 Referências bibliográficas......................................... 95

4. PRODUÇÃO DE MONOGRAFIAS E DE TESES:

A TENTAÇÃO DO PLÁGIO. .99

Michelle Bergadaà

4.1. Produção de monografias e de teses 101

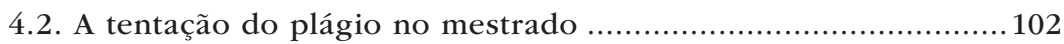

4.3. A tentação do plágio no doutoramento .................................106

4.4. A tentação de reagir ................................................... 110

4.5. Conclusão ................................................................... 113

5. FRAUDE ACADÉMICA DISCENTE E CONTEXTO MORAL................. 115 Hermano Thiry-Cherques

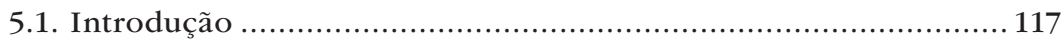

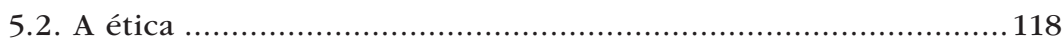

5.3. As fraudes académicas............................................... 121

5.3.1. Fraudes de reprodução ........................................... 121

5.3.2. Fraudes de pilhagem ............................................ 123 


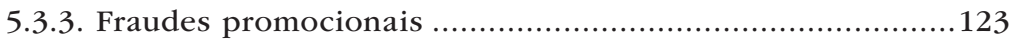

5.3.4. Fraudes de conteúdo .........................................124

5.3.5. Fraudes de produto........................................... 126

5.3.6. Fraudes de generalização .......................................... 127

5.4. A Academia .................................................................... 128

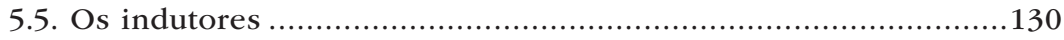

5.5.1. A liberdade condicionada ............................................ 131

5.5.2. A individualização equalizada ..................................... 134

5.5.3. A racionalização paradigmática ..................................... 137

5.6. Tolerância ....................................................................138

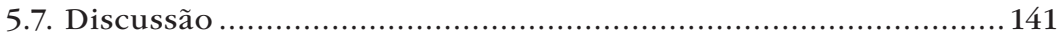

5.8. Referências bibliográficas........................................ 142

6. A ÉTICA COMO OBJETO DE ENSINO.................................... 145

Luís Adriano Oliveira e José Luís Afonso

6.1. Referências bibliográficas................................................ 152

7. A ÉTICA NA DOCÊNCIA UNIVERSITÁRIA:

ENTRE O IDEAL E O REAL ............................................. 153

Maria Teresa Estrela

7.1. Introdução................................................................... 155

7.2 Desafios éticos postos aos docentes................................ 160

7.2.1. Os contextos de mudança ........................................ 160

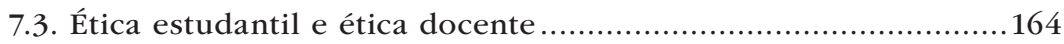

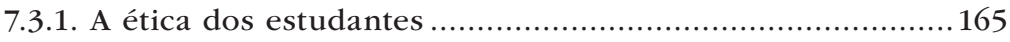

7.3.1.1. Outras temáticas de investigação sobre a ética dos estudantes.....................................169

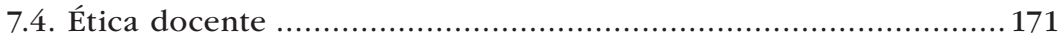


7.4.1. A ética docente no ensino superior em Portugal, essa desconhecida ............................................. 174

7.4.2. Alguns dados baseados na experiência......................... 175

7.4.3. A ética docente vista através das queixas dos alunos ........177

7.4.4. Os Estatutos das Universidades Públicas......................... 178

7.4.5. Um estudo exploratório e qualitativo sobre

a ética docente no ensino superior.................................. 182

7.5. Conclusão - Entre ideal e real, os professores,

a sua ética e os seus dilemas ............................................. 185

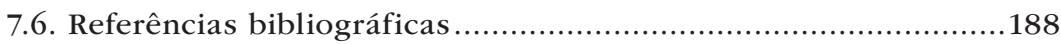

8. POLÍTICAS INSTITUCIONAIS, EM PORTUGAL, RELATIVAS À FRAUDE ACADÉMICA.......................................... 195

Paulo Peixoto, Denise Esteves, Ana Seixas, Filipe Almeida e Paulo Gama

8.1. A cultura da integridade académica 197

8.2. A integridade académica nos códigos das instituições de ensino superior em Portugal............................................200

8.3. Natureza dos documentos analisados ................................209

8.4. O enquadramento institucional da fraude académica ...............214

8.5. Comissões de ética ..................................................... 216

8.6. Códigos de conduta ..................................................... 218

8.7. Um olhar mais detalhado sobre os códigos de conduta ............218

8.8. Considerações finais ..................................................236

8.9. Referências bibliográficas .........................................238

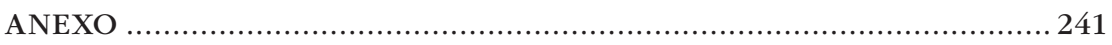

Transcrição, abreviada e editada, mas mantendo o tom coloquial, dos debates do Colóquio "A ética dos alunos e a tolerância de professores e instituições perante a fraude académica no ensino superior" 
(Página deixada propositadamente em branco.) 


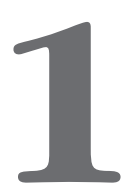

\title{
UMA CULTURA DE INTEGRIDADE PARA O ENSINO SUPERIOR
}

\author{
Filipe Almeida \\ Paulo Peixoto \\ Ana Seixas \\ Denise Esteves \\ Paulo Gama
}

Universidade de Coimbra

http://dx.doi.org/10.14195/978-989-26-1123-5_1 
(Página deixada propositadamente em branco.) 
Esta obra junta-se a uma outra (Almeida et al., 2015) para ambas se constituirem como duas faces de uma mesma moeda. Tendo um alcance distinto, as duas resultam de um mesmo projeto de investigação centrado na temática da fraude académica ${ }^{1}$ e complementam-se mutuamente. Nesta obra reunimos alguns dos textos que sustentaram as intervenções feitas pelos seus autores no colóquio final do projeto, que teve lugar na Faculdade de Economia da Universidade de Coimbra a 8 e 9 de maio de 2014. Trata-se de autores cujas reflexões foram muito importantes para a conceção e desenvolvimento do projeto. Alguns deles assumiram a função de consultores externos e o seu contributo estende-se muito para lá das reflexões que aqui deixam escritas.

Esta é uma obra eminentemente teórica, ao contrário da outra (que sistematiza os resultados empíricos, alcançados no âmbito do projeto, relativos à fraude académica cometida pelos estudantes em Portugal). A fraude académica e as suas variantes e dimensões; as suas causas e consequências; os obstáculos e as soluções inerentes ao seu enfrentamento; os atores envolvidos e os contextos da sua ocorrência são, entre outros, alvos de conceptualização, de escrutínio e de discussão. Discussão que aqui fica também expressa pela publicação, em tom coloquial, dos debates ocorridos entre os participantes ao longo dos dois dias do colóquio.

\footnotetext{
1 "A ética dos alunos e a tolerância de professores e instituições perante a fraude académica no ensino superior" (PTDC/CPE-CED/115915/2009), financiado no âmbito do Programa Operacional Temático Fatores de Competitividade (COMPETE) e comparticipado pelo Fundo Comunitário Europeu FEDER. O estudo foi desenvolvido no Centro de Estudos Sociais da Universidade de Coimbra.
} 
A ética e a moral são conceitos charneira desta obra, atravessando, sustendo e ligando as reflexões elaboradas nos capítulos que aqui reunimos. A ética é uma dimensão determinante das sociedades complexas atuais - multiculturais, multiétnicas, religiosamente plurais, marcadas por uma forte recomposição dos papéis sexuais, etc. (May e Delston, 2015). As instituições de ensino superior, com a massificação e a universalização deste nível de ensino, mas também devido à intensificação dos processos de internacionalização, enfrentam, também elas, de um modo crescente, os desafios da diversidade e da complexidade (Smith, 2015). Quer no plano institucional, quer no plano individual relativo às condutas dos seus diversos agentes, as intituições de ensino superior movem-se num contexto ético complexo que tem de ser problematizado, de modo a garantir uma qualificação generalizada de padrões comportamentais. Perseguindo esse desiderato, esta obra foca-se em várias dimensões da ética individual e institucional inerente às instituições de ensino superior.

Analisando a incidência da corrupção no ensino superior, Temple e Petrov (2004) sustentam que a ética e os padrões morais observáveis na esfera profissional têm origens diversas, destacando, em particular, a importância da cultura; seja a cultura nacional, seja a cultura organizacional, ou sejam ainda os traços culturais que decorrem da socialização familiar. O cruzamento de influências oriundas destas três áreas gera contextos e padrões diferenciados de tolerância à fraude. Numa perspetiva menos macroanalítica, poderíamos acrescentar a esses fatores transversais, entre outros, a educação formal, as trajetórias de vida ou as exigências e idiossincrasias de cada setor de atividade ou esfera profissional.

A educação formal merece uma atenção particular atendendo a que, neste âmbito, nos preocupamos com os fatores decisivos para a formatação de uma cultura de integridade no ensino superior. Como nota Tricia Bertram Gallant (2007), o conceito de integridade académica foi sendo retomado com a progressiva tomada de consciência 
do agravamento das práticas académicas desonestas cometidas pelos estudantes. Atendendo aos fatores elencados no parágrafo anterior, a questão que se coloca é, desde logo, a de saber se, e até que ponto, as instituições de ensino superior são capazes de alterar padrões éticos que são moldados e inculcados num quadro mais amplo. Nesta obra, a título de exemplo de uma primeira remissão para os conteúdos deste livro, a questão expressamente colocada por Luís Adriano Oliveira e José Luís Afonso é se a ética deve ou não deve (e, devendo, como) ser ensinada nas instituições de ensino superior. Esta é uma questão atual e pertinente que vem adquirindo relevância no contexto do estudo da ética no ensino superior (Löfström et al., 2015). Embora a pergunta de Luís Adriano Oliveira e José Luís Afonso e as respostas à pergunta não suscitem consensos, é fundamental questionar a ética pessoal que orienta o julgamento que os estudantes e professores fazem em relação à moralidade das suas ações e das intenções que lhe subjazem. Se relacionarmos a ética pessoal com a ética profissional, com a ética nos negócios ou com qualquer outra dimensão ética, dar-nos-emos conta que - para além dos dilemas e conflitos éticos que revelam que a ética não assenta em padrões comportamentais cristalizados e claramente assumidos - qualquer tentativa concreta para mudar eticamente os comportamentos, atuando diretamente sobre os indivíduos ou sobre um determinado contexto, no melhor, garante resultados positivos marginais e, por vezes, pode até gerar efeitos contraproducentes (Weave, 2014: 293). A complexidade da ética está precisamente neste seu caráter que a torna, ao mesmo tempo, rígida numas circunstâncias e flexível noutras circunstâncias.

A relevância da ética no ensino superior não se estende apenas à dimensão interna do sistema. Ainda que, nesta dimensão, a noção de justiça (nos domínios da avaliação dos estudantes; da avaliação e da promoção dos docentes; da gestão de diferenças culturais dos membros, cada vez mais heterogéneos, da Academia; da hierarquização de instituições e de cursos etc.) seja transversal e incontornável para 
o bom funcionamento do sistema. Mas a educação formal ministrada e obtida no ensino superior merece uma atenção particular, sobretudo, por causa da dimensão externa do sistema. O ensino superior forma para a vida e para a profissão e, nessa medida, porque contribui para transformar, padronizar e legitimar comportamentos, ainda que os impactes de uma formação ética sejam marginalmente positivos, não se pode perder de vista que a instrução de nível superior ocupa uma função decisiva na formatação do sistema de valores que enquadra a conduta moral no contexto social e profissional futuro.

Numa época em que as instituições de ensino superior portuguesas procuram reinventar a sua missão (Carvalho e Bruckmann, 2014) e redefinem o seu quadro de governação (Oliveira, Peixoto e Silva, 2014), depois de terem concluído - ainda que mais na forma do que na substância - um amplo processo de reformas curriculares (Veiga e Amaral, 2009), estranhamos que a questão da ética e da fraude não se constituam como matérias centrais desse vasto processo. Olhando para o plano formal, poder-se-ia argumentar o contrário, dada a profusão da adoção de códigos com preocupações de natureza ética. No último capítulo desta obra procedemos a um levantamento e caraterização desses códigos no panorama do ensino superior em Portugal. Para já, partilhamos o argumento de Weaver (2014: 293), que se mostra válido para a discussão que atravessa este livro, segundo o qual, por si só, um código de conduta tem um efeito limitado ou nulo nos comportamentos de natureza ética. Sendo importante notar, de acordo com o mesmo argumento, que, no contexto de uma qualquer organização onde predomine um clima fortemente orientado para as questões éticas, um código de conduta, ou qualquer outra medida formal, já tem condições para se tornar efetivo, na medida em que se converte num gerador e num difusor de valores amplamente partilhados.

Tratando-se de um problema de natureza ética com causas e consequências variadas, dentro e fora do sistema de ensino superior, 
em Portugal, a fraude académica cometida pelos estudantes não tem sido objeto de estudos amplos ou sistemáticos que permitam criar um corpo de conhecimento crítico e substantivo sobre o seu significado, as suas fronteiras e as suas controvérsias teóricas. Os trabalhos de Maria de Fátima Rocha e de Aurora Teixeira (2010), muito particularmente a Tese de Doutoramento realizada pela primeira das autoras (Rocha, 2006), assim como o trabalho de Ivo Domingues (2006) sobre o copianço, são pioneiros e lançam pistas e desafios importantes relativamente ao comportamento ético dos estudantes do ensino superior. Todavia, são abordagens que apenas se aproximam lateralmente de um fenómeno complexo, cuja extensão e diversidade estão longe de ser conhecidas. Como também se aproximam lateralmente os trabalhos de Luís de Sousa e de João Triães (2008) sobre corrupção. Isso não significa, pelo contrário - como o testemunham a nossa pesquisa e a nossa prática profissional, enquanto docentes do ensino superior - , que não haja crescentes preocupações e atitudes de vigilância junto da comunidade académica relativamente à fraude. Preocupações que se afiguram tanto mais prementes quanto as questões de natureza ética no domínio profissional estão cada vez mais na ordem do dia e quanto a fraude no ensino superior se reveste de especificidades próprias (Rumyantseva, 2005). Os dois livros que publicamos no âmbito do projeto referido visam contribuir para um debate e um conhecimento mais profundos de uma questão que vem ganhando relevância social e científica. O contributo mais teórico deixado nesta obra e os resultados da pesquisa vertidos no outro livro (Almeida et al., 2015) - combinando o olhar dos estudantes, dos docentes e das instituições - pretendem constituir-se como uma base de promoção de uma cultura de integridade para o ensino superior português.

Do vulgar "copiar nos exames" ao plágio mais ou menos sofisticado, do recurso ao trabalho académico realizado por familiares e amigos à compra anónima de trabalhos na Internet, da facilitação 
da fraude por inexistência de denúncia ou de vigilância à ausência de mecanismos externos de punição, são várias as evidências que revelam a permeabilidade do sistema de ensino superior à fraude (Noah e Eckstein, 2001). E, ainda assim, estaríamos aqui apenas a referir-nos à fraude cometida pelos estudantes. Para lá da existência de códigos de ética (Rezaee, Elmore e Szendi, 2001) e de outras medidas preventivas e punitivas, a realização de estudos sobre a ética no ensino superior é uma condição fundamental para combater a fraude (Heyneman, Anderson e Nuraliyeva, 2008). Por isso, quando e onde os estudos são raros, as políticas de prevenção e de combate à fraude são esparsas.

Os estudos sobre fraude académica, de que destacamos particularmente os trabalhos de Jacques Hallak e Muriel Poisson (2005, 2006 e 2007), que participaram no programa de pesquisa na qualidade de consultores (publicando esta obra uma reflexão sobre fraude de Jacques Hallak), mostram que o estudo da fraude se revela particularmente pertinente em termos da incidência do fenómeno, dos fatores que lhe estão associados e das soluções que têm vindo a ser encontradas por docentes e instituições (Lathrop e Foss, 2005; Almeida et al., 2014). A questão das novas tecnologias, enquanto motivador ou facilitador da fraude, mas também enquanto dispositivo que a pode inibir, está presente ao longo desta obra e tem vindo a constituir-se como um eixo recorrente das pesquisas mais recentes ( $C f r$. Penketh e Beaumont, 2014; Bruton e Childers, 2015).

A corrosão do caráter nas sociedades atuais, de que fala Richard Sennett (2001), poderia fazer supor uma incidência generalizada da fraude académica. Todavia, o que várias pesquisas têm vindo a revelar é que, não obstante a elevada frequência de atos de fraude (Blankenship e Whitley, 2000), as evidências do crescimento global deste fenómeno nas últimas décadas não são avassaladoras. Isso não significa que o fenómeno não tenha vindo a transformar-se (Eckstein, 2003), sendo essa transformação mais visível na relevância e na 
irrelevância que assumem certos modos de concretização da fraude (aparecendo a Internet como um dos instrumentos que mais receios transporta de difusão da fraude académica) e na maneira diferenciada como ela se dissemina socialmente e por áreas disciplinares. Mas também no modo como a questão da integridade académica tem vindo a formatar-se no âmbito da complexificação dos papéis desempenhados pelos docentes/investigadores, traçando linhas indefinidas e obscuras entre comportamentos éticos e não éticos (Macfarlane, Zhang e Pun, 2014).

Procurar e consolidar uma cultura de integridade para o ensino superior obriga-nos a olhar em várias direções. As políticas das instituições de ensino superior e as atitudes dos docentes perante a fraude, por configurarem "culturas de fraude", apresentam-se como dois dos fatores mais relevantes de análise da fraude académica (Ashworth, Bannister e Thorne, 1997). Por isso mesmo são consideradas nesta obra, sendo abordadas em várias dimensões. Num aparte, cabe destacar que a questão das políticas institucionais não tem só a ver com práticas de prevenção e de punição da fraude dos estudantes e docentes/investigadores, mas também com políticas institucionais que podem ser, elas próprias, enganadoras e ancorar-se em padrões éticos criticáveis ou reprováveis, como é o caso das políticas levadas a cabo no âmbito do marketing educativo (Bradley, 2013), do posicionamento em rankings (Erkkilä, 2014; Mok, 2015), do planeamento estratégico (Mueller, 2015) ou ainda da prospeção de novas fontes de financiamento (Nkrumah-Young e Powell, 2011). Por outro lado, independentemente de recorrerem ou não à fraude, os próprios estudantes não manifestam uma aversão deliberada e premeditada a medidas punitivas de fraude académica (Roig e Ballew, 1994). Pelo contrário, são eles, sobretudo os que obtêm melhores classificações, que exigem medidas mais ativas de prevenção e, sobretudo, de punição. Sendo uma parte incontornável da promoção de uma cultura 
de integridade, os estudantes e a sua ética são também objeto dos olhares dos capítulos que dão forma a esta obra.

Ainda assim, para lá das políticas institucionais, é a conduta dos docentes e o grau de identificação dos estudantes com as matérias ensinadas que muitas vezes se convertem em fatores inibidores ou potenciadores da fraude (Kerkvliet e Sigmund, 1999). Contextos de maior proximidade professor-aluno, com turmas mais pequenas que potenciem um maior envolvimento em sala de aula, com modalidades de avaliação que combatam o absentismo, ou com assuntos que sejam percebidos como importantes, tendem a reduzir o recurso à fraude. Além disso, as pesquisas mostram igualmente que professores que têm preocupações com o espaço onde se realiza o exame, que evitam exames de escolha múltipla e que desenvolvem várias versões de um mesmo exame conseguem mais facilmente inibir a fraude. $\mathrm{Na}$ verdade, são muitos e muito diversos os fatores que enquadram as possíveis justificações de ocorrência de fraude académica cometida por estudantes, quer essas justificações remetam para decisões racionais, quer para mecanismos de racionalização definidos a posteriori (Brent e Atkisson, 2011).

A literatura tem vindo a mostrar que a fraude académica é uma variável dependente da área disciplinar em que se estuda, do sucesso académico, da realização ou não de atividades extracurriculares, da idade e do sexo, mas também de fatores externos ligados a um mercado que disponibiliza crescentemente canais de disseminação da fraude (McCabe e Trevino, 1997; Osipian, 2012). Áreas científicas como o direito e as ciências económicas ou empresariais tendem a ser, em regra, mais vulneráveis à fraude académica. O insucesso escolar ou a tendência para obter maus resultados é um fator indutor da fraude. Esta tendência manifesta-se igualmente junto dos estudantes mais envolvidos em atividades extracurriculares. Menos evidente, mas por vezes referenciada, é a tendência para que os homens mais que as mulheres manifestem propensão para a fraude académica. 
Contudo, é a influência do grupo de pares, em termos de comportamentos (recorrer ou não recorrer à fraude de modo generalizado) e de atitudes (condenar ou tolerar a fraude, por exemplo) que, dando corpo a uma "cultura de fraude", mais parece inibir ou potenciar a fraude. As diferentes preponderâncias destes fatores e os modos como se concretizam mostram, por si mesmos, a complexidade do fenómeno. Essa complexidade pode ser levada ao extremo se considerarmos o argumento de Bruun (2014), segundo o qual uma política de tolerância zero em relação ao plágio é contraproducente com a lógica académica, uma vez que essa política aniquila a inspiração e a criatividade. A relevância deste argumento atravessa o debate sobre a questão de saber se o plágio é predominantemente uma questão ética ou um problema comportamental (East, 2010). Embora conheçamos as teorias que apontam a pirataria como uma fonte de inovação, não vamos tão longe quanto o argumento de Bruun. Mas reunimos alguns textos que nos ajudam a enfrentar a complexidade do fenómeno. Estamos certos que a sua leitura será produtiva para todos aqueles que estiverem empenhados em promover uma cultura de integridade no ensino superior.

Jacques Hallak reflete sobre novos modos de regulação da ética e da fraude no ensino superior. A fraude académica é um fenómeno amplo e deve ser abordado nessa sua amplitude. Os dois modos tradicionais de expressão das políticas de combate à fraude académica comportam limites e virtudes que, devidamente ponderados, exigem uma nova modalidade de regulação. Nas suas múltiplas formas de manifestação (e Jacques Hallak considera 5), a fraude académica é algo que resulta do desajustamento entre aquilo que se espera das instituições de ensino superior e aquilo que elas têm para oferecer. Nessa medida, há políticas institucionais que se apresentam como necessárias para regular esse desajustamento. Sobretudo porque as políticas de enfrentamento da fraude académica baseadas no modelo "transitivo" (informação, prevenção, vigilância/deteção, sanções/ 
penalidades) funcionam de modo limitado e podem ter resultados contraproducentes. Hallak destaca 4 vetores para repensar as políticas institucionais e promover uma política integrada de enfrentamento. Esta política integrada passa por redefinir os objetivos, os métodos e as modalidades de organização da oferta de formação a nível superior.

Procurando debater o que deve ser a gestão do plágio estudantil e os modos de lidar com as questões de ética, de fraude e de ludíbrio, Jude Carroll traz-nos uma interessante tipificação da fraude, ao mesmo tempo que apresenta um modelo de gestão para diferentes manifestações da fraude académica. Partindo da constatação que o plágio estudantil é uma preocupação crescente no domínio do ensino superior, e elencando algumas das razões da sua manifestação, Jude Carroll propõe uma política institucional e um instrumento concreto que encaram o plágio como uma prioridade maior das instituições de ensino superior. Nessa perspetiva parte de uma distinção concetual que separa plágio, ludíbrio e fraude, o que coloca a intencionalidade e a necessidade de desenvolver competências no centro nevrálgico das políticas institucionais. O eixo operacionalizador de uma política institucional é o "Gabinete para a Conduta Académica", cujos objetivos principais passam por: elaborar políticas concretizáveis e assentes em procedimentos entendidos como justos, quer na sua definição e alcance, quer na sua aplicação concreta; garantir que os procedimentos são suficientemente simples e abrangentes para gerir grandes quantidades de casos; e assegurar que os docentes possam eles mesmos, no vasto conjunto de incumbências que lhe são reservadas e num quadro de prioridades que concorrem umas com as outras, aplicar esses procedimentos.

O plágio concretizado na realização de dissertações de mestrado e de teses de doutoramento, e as diferentes razões de ocorrência de plágios nestes dois níveis académicos, são o objeto do texto de Michelle Bergadaà. A autora parte da análise de casos reais e de comentários a esses casos para, através de uma análise de 
conteúdo, referenciar as transversalidades e isolar os significados comuns atribuídos a cada caso. O que parece ser muito claro é que os comportamentos fraudulentos previamente adquiridos tendem a repetir-se sucessivamente. As "Teses de complacência" mostram que, ao nível do doutoramento, as implicações são de outra ordem, pois as fraudes dos estudantes não são meramente individuais e não podem ser separadas dos seus orientadores e do contexto institucional. Por outro lado, é neste nível de formação que as instituições, por tudo o que está em causa, têm nitidamente mais dificuldades em reagir ao plágio e, paradoxalmente, parece ser neste nível que a impunidade é maior. Esta questão permite problematizar a necessidade em desenvolver uma política diferenciada de prevenção e de combate à fraude em diferentes níveis de ensino. E permite também questionar em que medida a profusão de códigos e de regulamentos excessivamente genéricos e de políticas institucionais insuficientemente desenvolvidas não se constitui como elemento estratégico de silenciamento de uma dimensão incómoda para as instituições de ensino superior.

Hermano Thiry-Cherques começa por situar a fraude académica por referência às correntes do pensamento ético contemporâneo. Apresenta, de seguida, 6 formas de fraude comuns na Academia (fraude de reprodução, fraudes de pilhagem, fraudes promocionais, fraudes de conteúdo, fraudes de produto e fraudes de generalização). Considerando e discutindo algumas especificidades da Academia, analisa os indutores da fraude numa perspetiva societal. Termina com uma proposta que visa atuar sobre as causas e os móbeis de modo a atenuar os efeitos e a diminuir a incidência da fraude académica discente. Com uma abordagem envolvente, fundada na filosofia, Thiry-Cherques traz-nos uma discussão sobre fraude que transcende a fraude meramente académica. Mas mostra que a fraude académica tem muito a ver com a própria transformação do papel da Academia ao longo de séculos e que a Academia e sociedade são indissociáveis. 
Nesse contexto, e na perspetiva da regeneração da Academia, a fraude pode não ser um fenómeno meramente negativo.

A ética como objeto de ensino na educação de nível superior, já o dissemos em cima, é uma questão que levanta fortes discussões. Todavia, Luís Adriano Oliveira e José Luís Afonso, recorrendo aos ensinamentos retirados da sua experiência e prática profissional, advogam as virtualidades de introdução do ensino específico da ética nas instituições de ensino superior. Mas sublinham a necessidade em promover um ensino em que a ética normativa se conjuga com ética da responsabilidade, com claro predomínio para a segunda.

O texto de Maria Teresa Estrela, incidindo sobre a ética na docência universitária, complementa as análises precedentes. Numa época de grande transformação das universidades, as funções dos professores não ficam à margem dessa transformação. A questão essencial é que se os contextos e as características particulares dessa transformação exigem um reforço da ética e da moral, o que se verifica é uma progressiva ausência de padrões éticos. Considerando este panorama, Maria Teresa Estrela aborda os problemas éticos mais comuns que se colocam aos professores do ensino superior, procura dar conta do modo como os docentes representam esses problemas e examina as respostas que algumas investigações empíricas têm dado em relação ao pensamento e ao agir ético dos docentes, assim como as interrogações que delas decorrem. Por outro lado, a autora olha também para a ética dos estudantes, pois, sendo evidente que as pesquisas sobre a ética estudantil cresceram a um ritmo muito superior às pesquisas sobre ética docente, é notório que as falhas éticas dos estudantes desafiam também a ética docente. Uma outra questão pertinente, levantada pela autora, e que faz a ponte com o capítulo seguinte, resulta do facto de os professores serem encarados como o eixo estruturante que assegura a ética universitária, esperando-se que eles sejam exemplares, independentemente de existirem ou não códigos éticos formais; 
observando Maria Teresa Estrela que as instituições têm vindo a investir em códigos de boas práticas.

$\mathrm{O}$ que fazemos no capítulo 8 é precisamente um levantamento sistemático e uma caraterização dos códigos e regulamentos relativos a questões de ética e de integridade nas instituições portuguesas de ensino superior. O resultado mais visível desse levantamento é a constatação de que, num panorama tendencial de ausência de códigos de ética e de integridade académica, se assiste à emergência de preocupações dessa natureza, ainda que os códigos existentes assumam um caráter predominantemente genérico. Ou seja, em rigor, a formalização das preocupações com a ética e com a integridade académica existe, mas os códigos não são suficientemente abrangentes (restringem-se aos alunos e a formas restritas de fraude) e não alcançam um nível instrumental e de operacionalização, limitando-se a cumprir a função básica de regulamentação nesta matéria. Aliás, como constatamos noutro lugar (Almeida et al., 2015), o desconhecimento dos estudantes e dos professores portugueses do ensino superior sobre a existência ou inexistência dos próprios códigos é elevado. Ainda assim, deve assinalar-se que é nas instituições e nos cursos da área da saúde (medicina, farmácia, enfermagem) que o nível de formalização é maior.

A cultura de integridade é um tema abrangente que não se retringe ao ensino superior. Aparece muitas vezes como um conjunto de medidas que pode ser imposto por uma liderança forte ou por uma regulamentação detalhada. Porém, como qualquer cultura, exige uma ampla partilha e envolvimento social daqueles a quem se dirige, sob pena de fazer apenas parte da arquitetura formal das instituições. As instituições de ensino superior não estão hoje à margem da cultura da instrumentalização que parece invadir todas as esferas, convidando à naturalização da ideia de que os meios justificam os fins. Essa generalizada cultura da instrumentalização concorre com a cultura da integridade. E no ensino superior, devemos sublinhá-lo, ela 
estende-se às práticas de todos os agentes, começando pelas práticas das próprias instituições. Todavia, a complexidade inerente a este contexto não impede a necessidade e a possibilidade de desenvolver uma cultura de integridade no universo do ensino superior.

\subsection{Referências bibliográficas}

Almeida, F.; Seixas, A.; Gama, P. e Peixoto, P. (2015), A Fraude Académica no Ensino Superior em Portugal - um estudo sobre a ética dos alunos portugueses. Coimbra: Imprensa da Universidade de Coimbra.

Almeida, F.; Seixas, A.; Gama, P.; Peixoto, P. e Esteves, D. (2014), Academic Fraud Higher Education Students in Portugal: A Study of Types, Practices and Tolerance of Fraud. In Aurora A. C. Teixeira, António Maia, José António Moreira e Carlos Pimenta. (Orgs.). Interdisciplinary Insights on Fraud. Newcastle upon Tyne: Cambridge Scholars Publishing, pp. 169-192.

Ashworth, P.; Bannister, P. e Thorne, P. (1997), Guilty in whose eyes? University Students' Perceptions of Cheating and Plagiarism in Academic Work and Assessment. Studies in Higher Education, 22(2), pp. 187-203.

Blankenship, K. L. e Whitley Jr., B. E. (2000), The relation of general deviance to academic dishonesty. Ethics \& Behavior, 10, pp. 1-12.

Bradley, J. (2013), Integrity in higher education marketing? A typology of misleading data-based claims in the university prospectus. International Journal for Educational Integrity, 9(2), pp. 74-88.

Brent, E., e Atkisson C. (2011), Accounting for Cheating: An Evolving Theory and Emergent Themes. Research in Higher Education, 52(6), pp. 640-658.

Bruton S. e Childers, D. (2015), The ethics and politics of policing plagiarism: a qualitative study of faculty views on student plagiarism and Turnitin®. Assessment E Evaluation in Higher Education, publicado online.

Bruun, H. H. (2014), Zero Tolerance to Plagiarism Will Kill Inspiration: a Critique for Academic Meritocracy. Ideas in Ecology and Evolution, 7(1), 34-37. 
Carvalho, T. e Bruckmann, S. (2014), Reforming Portuguese Public Sector: A Route from Health to Higher Education. Higher Education Dynamics, 41, pp. 83-102. Domingues, I. (2006), O copianço na Universidade. O grau zero da qualidade. Lisboa: Media XXI.

East, J. (2010), Judging plagiarism: a problem of morality and convention. Higher Education, 59(1), pp. 69-83.

Eckstein, M. A. (2003), Combating Academic Fraud. Towards a Culture of Integrity. Paris: Unesco - International Institute for Educational Planning.

Erkkilä, T. (2014), Global University Rankings, Transnational Policy Discourse and Higher Education in Europe. European Journal of Education, 49(1), pp. 91-101. Gallant, T. B. (2007), The Complexity of Integrity Culture Change: A Case Study of a Liberal Arts College. The Review of Higher Education, 30(4), pp. 391-411.

Hallak, J. e Poisson, M. (2005), Ethics and corruption in education: an overview. Journal of Education for International Development, 1(1). Obtido em 26 de abril de 2014 em http://www.equip123.net/JEID/articles/1/1-3.pdf

Hallak, J. e Poisson, M. (2006), Academic Fraud, Accreditation and Quality Assurance: Learning from the Past and Challenges for the Future, in GUNI (Global University Network for innovation), Higher education in the world 2007: Accreditation for quality assurance: What is at stake? New York: Palgrave Macmillan, pp 109-123.

Hallak, J. e Poisson, M. (2007), Corrupt Schools, Corrupt Universities: What Can Be Done? Paris: Unesco - International Institute for Educational Planning.

Heyneman, S. P.; Anderson, K. H. e Nuraliyeva, N. (2008), The Cost of Corruption in Higher Education. Comparative Education Review, 1(52), pp. 1-25.

Kerkvliet, J. e Sigmund, S. L. (1999), Can We Control Cheating in the Classroom? Journal of Economic Education, 30(4), pp. 331-343.

Lathrop, A. e Foss, K. (2005), Guiding Students from Cheating and Plagiarism to Honesty and Integrity: Strategies for Change. Westport: Libraries Unlimited.

Löfström E.; Trotman, T.; Furnari, Mary e Shephard, Kerry (2015), Who teaches academic integrity and how do they teach it? Higher Education, 69(3), pp. 435-448.

Macfarlane B., Zhang J. e Pun A. (2014), Academic integrity: a review of the literature. Studies in Higher Education, 39(2), pp. 339-358. 
May, L. e Delston, J. B. (Orgs.), (2015), Applied Ethics: A Multicultural Approach. Londres: Routledge, $\sigma^{\mathrm{a}}$ edição.

McCabe, D. L. e Trevino, L. K. (1997), Individual and contextual influences on academic dishonesty: A multicampus investigation. Research in Higher Education, 38(3), pp. 379-396.

Mok, K. H. (2015), Higher Education Transformations for Global Competitiveness: Policy Responses, Social Consequences and Impact on the Academic Profession in Asia. Higher Education Policy, 28(1), pp. 1-15.

Mueller, R. A. (2015), Do values drive the plan? Investigating the nature and role of organizational values in university strategic planning. Tertiary Education and Management, 21(1), pp. 41-55.

Nkrumah-Young, K. K. e Powell P. (2011), Exploring higher education financing options. European Journal of Higher Education, 1(1), pp. 3-21.

Noah, H. J. e Eckstein M. A. (2001), Fraud and Education. The Worm in the Apple. Lanham: Rowman \& Littlefield Publishers, Inc.

Oliveira, A. C.; Peixoto, P. e Silva, S. (2014), O papel dos Conselhos Gerais no Governo das Universidades Públicas Portuguesas: a lei e a prática. Coimbra: Imprensa da Universidade de Coimbra.

Osipian, A. L. (2012), Economics of Corruption in Doctoral Education: The Dissertations Market. Economics of Education Review, 31(1), pp. 76-83.

Penketh, C. e Beaumont, C. (2014), 'Turnitin said it wasn't happy': can the regulatory discourse of plagiarism detection operate as a change artefact for writing development? Innovations in Education and Teaching International, 51(1), pp. 95-104.

Rezaee, Z.; Elmore, R. C. e Szendi, J. (2001), Ethical behavior in higher educational institutions: The role of the code of conduct. Journal of Business and Ethics, 30(2), pp. 171-183.

Rocha, M. de F. (2006), Stock de Capital Humano, Fraude Académica e Corrupção. Uma Análise Intra e Inter Países. Tese de doutoramento: Universidade do Porto.

Roig, M. e Ballew, C. (1994), Attitudes toward cheating of self and others by college students and professors. Psychological Record, 44(1), pp. 3-12.

Rumyantseva, N. L. (2005), Taxonomy of corruption in higher education. Peabody Journal of Education, 80(1), pp. 81-92. 
Sennett, R. (2001), A Corrosão do Caráter: As Consequências Pessoais do Trabalbo no Novo Capitalismo. Lisboa: Terramar.

Smith D. G. (2015), Diversity's Promise for Higher Education - Making it Work. Baltimore: John Hopkings University Press, $2^{\mathrm{a}}$ edição.

Sousa, L. e Triães, J. (2008), Corrupção e os portugueses-atitudes, práticas e valores. Lisboa: RCP Edições.

Teixeira, A. A. C. e Rocha, M. F. (2010), Academic misconduct in Portugal: results from a large scale survey to university economics/business students. Journal of Academic Ethics, 8(1), pp. 21-41.

Temple, P. e Petrov, G. (2004), Corruption in Higher Education: Some Findings from the States of the Former Soviet Union. Higher Education Management and Policy, 1(16), pp. 83-99.

Veiga, A. e Amaral, A. (2009), Survey on the implementation of the Bologna process in Portugal. Higher Education, 57(1), pp. 57-69.

Weave, G. R. (2014), Encouraging Ethics in Organizations: A Review of Some Key Research Findings. American Criminal Law Review, 51, pp. 293-317. 
(Página deixada propositadamente em branco.) 


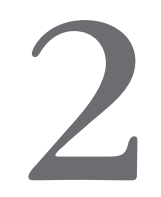

ÉTICA E FRAUDE NO ENSINO SUPERIOR:

À PROCURA DE NOVOS MODOS DE REGULAÇÃo

\author{
Jacques Hallak
}

Consultor Internacional Universidade Jules Verne

bttp://dx.doi.org/10.14195/978-989-26-1123-5_2 
(Página deixada propositadamente em branco.) 


\section{1. Ética e fraude no ensino superior}

Há uma dezena de anos, verificava-se um certo prazer a citar casos de fraude académica que passavam por verdadeiros escândalos, afetando o mundo da educação. Hoje os exemplos de fraude académica tornaram-se de tal modo numerosos que as informações que lhes dizem respeito passam quase despercebidas. É verdade que a fraude académica - contrariamente ao que é suposto - não é monopólio dos estudantes. É um "desporto" praticado por todos os protagonistas do campo educativo. Mesmo se a fraude é provavelmente mais importante entre os estudantes, ela é praticada pelos professores, os investigadores, as universidades e até mesmo, em certos países, pelos sindicatos e as administrações centrais e locais.

A generalização das práticas de fraude académica interpela os cidadãos bem como os parceiros e os elementos responsáveis pela educação. Depois de relembrar a definição de fraude académica, a primeira parte deste trabalho vai mostrar que a fraude académica contribui em certa medida para a regulação do funcionamento do setor de ensino e em particular do ensino superior, apresentando alguns exemplos de fraudes praticadas pelos diferentes atores da educação.

No entanto, porque se trata de um desvio, um desrespeito das normas e dos códigos em vigor no setor da educação, a fraude tem um custo económico, social e moral muito elevado e convoca medidas de luta para impedir a sua prática e evitar o seu desenvolvimento. A observação das políticas levadas a cabo em diferentes países mostra que estas relevam ora de abordagens de "management" (baseadas em princípios jurídicos de direito de prevenção e de sanção), ora 
de abordagens "éticas" (como agir sobre comportamentos insistindo nas dimensões morais: princípios de responsabilidade e de dever).

Na segunda parte, serão analisados os méritos e os limites destas abordagens que, no essencial, estão centradas no melhoramento da integridade do ensino superior e que, nem sempre, parecem eficazes. A reflexão conduzir-nos-á a perguntar se não será necessário interrogarmo-nos sobre os conteúdos, os métodos e as finalidades do ensino superior. Com efeito, se a fraude académica exprime um ajustamento, uma reação de adaptação entre o que é esperado da universidade e a realidade do que é a sua oferta, lutar contra a fraude passa então por um esforço de dar coerência às práticas em vigor no ensino superior para responder à evolução das expectativas dos estudantes e, de modo geral, de toda a sociedade.

Na terceira e última parte, em jeito de conclusão, serão apresentadas algumas pistas de reflexão para procurar conciliar as tensões observadas entre o objetivo imperativo de redução da fraude académica - as oportunidades de comportamentos desviantes bem como as novas possibilidades de deteção e de controlo da fraude propostas pelas novas tecnologias, por um lado, e, por outro lado, um ambiente caracterizado por uma superabundância de dados e de fontes de saber relativamente a quase todas as disciplinas acessíveis sem entraves e sem necessidade de mediação pelas instituições de ensino superior.

\subsection{A fraude académica participa na regulação do ensino superior}

Embora haja tendência para considerar que a fraude académica corresponde à fraude nos exames e nos diplomas, na verdade, devem acrescentar-se mais três manifestações da fraude académica: o plágio, a obtenção de validações e as falsificações (irregularidades nas inscrições e nos documentos emitidos pela administração). 
Importa assinalar, desde já, que os dados estatísticos sobre a fraude académica são raros, resultando por vezes de inquéritos junto de estudantes ou de instituições de ensino específicas, muitas vezes limitados a exemplos de fraudes reveladas por denúncias ou artigos de jornais. As informações são pontuais e não permitem generalizações baseadas em trabalhos estatísticos consistentes. Com exceção feita, sem dúvida, dos resultados de trabalhos de auditoria levados a cabo regularmente pelas entidades administrativas (por exemplo: Tribunais de Contas, em França; Auditoría Geral, na América Latina; Gabinete do Auditor Geral, no Nepal) e que podem dar conta de irregularidades no funcionamento do setor, as informações reveladas não podem justificar - com todo o rigor - ações de luta contra a fraude unicamente ao nível dos indivíduos, dos grupos, ou das administrações a que a fraude diz respeito. Isso não significa que os efeitos sobre as opiniões públicas - que entendem que o significado destes desvios de comportamento vão para além das entidades sobre as quais recaem - não provoquem pressões a favor de ações de política geral de luta contra a fraude, recaindo por vezes sobre o conjunto do setor da educação.

\subsubsection{As fraudes nos exames}

Os casos a seguir indicados constituem uma fraude nos exames em todos os níveis de ensino: (i) pelos professores ou pelas instituições de ensino: a aceitação de irregularidades nas inscrições; os enunciados de provas; a tolerância em relação a fraudes cometidas pelos estudantes; a admissão com sucesso apesar dos resultados abaixo das normas pré estabelecidas; (ii) pelos estudantes: a comunicação entre os candidatos durante as provas; a utilização de informações ou de documentos não autorizados no decorrer das provas; a utilização de documentos pessoais, nomeadamente de cábulas, ou de meios de 
comunicação informáticos - a substituição da identidade aquando da realização das provas; qualquer falsificação ou uso de falsificação de um documento emitido pela administração, incluindo documentos de identidade ou diplomas. Assim, a fraude nos exames pode ser um facto levado a cabo pelos estudantes, pelos examinadores e pelos professores. São apresentados em seguida alguns exemplos disso:

(i) fraudes levadas a cabo pelos professores e pelas instituições: Foi possível observar que em certas circunstâncias, os professores admitem a exame estudantes que não estão no nível pretendido. O caso acontece particularmente nos estudos de master especializados, cuja sobrevivência (e financiamento) depende da capacidade dos professores atraírem um número suficiente de estudantes. Não é raro observar que relatórios de estágio medíocres ou que monografias de qualidade duvidosa sejam validados. Até ao nível das defesas de teses de doutoramento, as oportunidades de fraude são utilizadas com a cumplicidade passiva ou ativa dos orientadores de tese e/ou da universidade. Em certos casos, a admissão e a escolha da menção atribuída podem depender de fatores que estão relacionados mais com as expetativas da universidade do que com a simples qualidade do relatório de tese. Estes casos de fraude podem ser considerados como modos de regulação das tensões/conflitos entre a necessidade financeira de assegurar um mínimo de inscrições de estudantes e a integridade das instituições, entre uma qualidade insuficiente das monografias de masters ou de teses e o imperativo de obtenção de bolsas ou de assegurar estágios no mundo do trabalho.

(ii) fraudes nos exames levadas a cabo pelos estudantes: As fraudes nos exames fornecem todos os anos a possibilidade de a Imprensa (jornais e revistas) produzir uma quantidade considerável de artigos de informação sobre o tema. Um inquérito relativamente recente (2010), 
levado a cabo por Pascal Guibert e Christophe Michaut junto de 1815 estudantes inscritos numa universidade pluridisciplinar francesa, dá uma ideia da amplitude do fenómeno: mais de $70 \%$ dos estudantes interrogados confessam ter feito batota ao longo da sua escolaridade. $4,7 \%$ dos estudantes interrogados admitem ter feito batota na escola primária, 48,3\% no ensino básico, 35,6\% no secundário e 11,4\% na universidade (Pech, 2010). É evidente que estes números não podem ser considerados como representativos da fraude relativamente ao conjunto da população de alunos e estudantes de França. Os números podem estar a sobrestimar a média nacional. No entanto, a amplitude da fraude revelada sugere que ela tem um efeito "regulador por defeito" dos fluxos de alunos e de estudantes ao longo da escolaridade, porque as taxas de fraude podem contribuir para aumentar as taxas de transição entre classes. Assim, taxas muito elevadas de fraude (não sancionada) no básico e no secundário têm por efeito mecânico aumentar a pressão com vista às inscrições em estudos superiores. É evidente que a relativa modéstia dessas taxas reduz o efeito mecânico.

\subsubsection{O plágio}

De acordo com uma definição dada pela universidade de Genebra, o plágio

\footnotetext{
"consiste em inserir, num trabalho académico, formulações, frases, passagens, imagens, ou capítulos inteiros, bem como ideias ou análises retiradas de trabalhos de outros autores, fazendo-os passar por seus. O plágio é realizado por parte do autor do trabalho, ora pela apropriação ativa dos ditos textos ou ideias de outrem, ora pela omissão da referência correta aos textos ou às ideias de outrem e às suas fontes." (Universidade de Genebra, 2013)
} 
Também não existem informações sobre o plágio que permitam medir a importância do fenómeno. Mas existem indicações parciais convergentes que deixam transparecer que este tipo de fraude está relativamente desenvolvido e terá aumentado ao longo dos últimos anos, nomeadamente em virtude das facilidades oferecidas pela Internet. Investigadores, redatores de teses, ou mesmo alunos do secundário e estudantes do superior cometem plágio (por vezes sem o saber), recorrendo simplesmente à riqueza da documentação acessível, utilizando os motores de busca. Nas atividades de formação e de investigação, o plágio coloca um triplo problema: (i) definições de limites: a partir de que momento a não indicação da origem de uma citação ou de um trabalho pode ser considerada como plágio?; (ii) de propriedade intelectual: a apropriação para interesse próprio de um trabalho feito por outrem equivale quase a um roubo; (iii) de regulação do sistema de ensino: por exemplo, o mercado de teses vendidas "chave na mão" fragiliza a apreciação que recai sobre os doutoramentos atribuídos pelas instituições de ensino superior. $\mathrm{Na}$ prática, só os "plágios grosseiros" são por vezes detetados e dão lugar a recusas de certificação dos trabalhos de investigação ou de formação. É provável que na sua grande maioria os plágios não sejam detetados; em consequência, as avaliações dos trabalhos de investigação e/ou os controlos de qualidade dos resultados dos estudos são frágeis, afetando ao mesmo tempo as condições de regulação do sistema de formação. No entanto - como adiante se verá - têm vindo a promover-se iniciativas para melhor detetar o plágio e assegurar uma maior integridade neste domínio.

\subsubsection{A obtenção de títulos ou de validações através de meios ilegais}

A fraude académica adquire aqui a forma de obtenção de notas, certificados, diplomas, ou de documentos utilizados nos exames 
mediante a aceitação de remunerações, de favores sexuais, ou sim-

plesmente de nepotismo. A fraude resulta, de certo modo de uma transação. Este tipo de fraude, que pode desenvolver-se em todos os níveis e tipos de ensino, não dá lugar a inquéritos sistemáticos e representativos, suscetíveis de medir a importância do fenómeno. Mas existem indicações, por vezes anedóticas, que permitem avaliar a diversidade das oportunidades de fraude, dando lugar a distorções na regulação do sistema de educação: em alguns países do Sahel, as chefias de estabelecimentos escolares rurais queixam-se da rigidez da organização do calendário do ano letivo que impede as crianças de estarem presentes nas aulas durante o período das colheitas; alguns pais ganham o hábito de pagar aos professores ou aos responsáveis dos estabelecimentos de ensino para que estes falsifiquem o número de faltas nas pautas de presença (obrigatória), declarando que o seu educando esteve presente nas aulas (quando, na verdade, estava no campo). Em certos países da África Central, os diretores de departamentos universitários declaram que o acesso a um determinado curso não é sempre em função do nível académico dos candidatos mas da sua disponibilidade para pagar um direito (ilegal).

\subsubsection{As falsificações (irregularidades nas inscrições, produção de falsos documentos administrativos)}

Neste caso, a fraude académica não dá lugar a uma transação entre corruptor e corrompido. A produção por um candidato a um emprego de documentos falsos não detetados, atestando a sua elegibilidade para determinada função (professor, inspetor...), a não inscrição de um estudante que pagou os direitos a um secretário da administração universitária, a produção de um certificado que atesta o domínio da língua inglesa por parte de um candidato estrangeiro à admissão numa instituição universitária britânica, a ausência 
de rigor na verificação de um dossier de validação de um projeto de curso de mestrado apresentado por uma universidade, etc. são alguns dos exemplos, entre muitos outros deste tipo, de fraude académica. É claro que as falsificações afetam diretamente a regulação do sistema: elas têm como efeito fragilizar a qualidade da formação, reduzir a eficácia dos recursos utilizados e pôr em causa o princípio de igualdade de acesso à educação. Para ilustrar este fenómeno de falsificação, limitar-nos-emos a citar aqui o exemplo de um país da África subsaariana, o Mali onde, por ocasião de um seminário nacional de alto nível que teve lugar em 2009, o reitor da Universidade de Ciências Jurídicas e Políticas denunciou a presença de mais de 3200 estudantes ilegais, "porque não estão inscritos em lugar nenhum", pedindo a sua exclusão. Os líderes estudantis rejeitaram a afirmação do reitor, produzindo documentos administrativos emitidos pela administração universitária para esses estudantes. $O$ inquérito posto em marcha para resolver este conflito revelou a existência de numerosas irregularidades: inscrições, cobrança de direitos, registos dos estudantes, etc. Podemos imaginar os riscos de paralisação (infelizmente justificados) do ano universitário provocado por um conflito desta natureza (FMPOS, 2013).

Estas diferentes manifestações da fraude académica, que não podem dar lugar a medidas quantitativas precisas e representativas, contribuem no entanto para a regulação do setor de ensino superior e fazem apelo a políticas voluntaristas para lhes fazer frente, tendo em conta os objetivos deste tipo de ensino.

\subsection{As políticas de luta contra a fraude académica: management e ética}

Simplificando, podemos considerar que se distinguem geralmente três etapas nas abordagens para travar a fraude: a) prevenção através 
de informação e sensibilização; b) observação, vigilância e deteção de fraudes; c) anulação dos efeitos da fraude e sanções. O que poderíamos designar por "triângulo virtuoso". É evidente que as políticas a pôr em prática devem estar adaptadas a cada tipo de fraude académica. Assim, uma fraude cometida por ignorância (o que é por vezes o caso quando um estudante obtém do vizinho uma resposta a uma questão prática divulgada nas salas de exame) não pode dar lugar a uma sanção da mesma natureza que uma fraude em que um professor é pago para rever em alta a nota de um aluno, ou ainda a fraude em que um estudante submete formalmente um relatório ou uma tese comprados pela Internet num "site especializado". Contudo, alguns princípios gerais inspiram as escolhas das políticas de luta contra a fraude académica.

\subsubsection{Prevenção através de informação e sensibilização: o papel central da ética}

Numerosas universidades lançaram-se, ao longo dos últimos quinze anos, no aperfeiçoamento e adoção da carta ética (Alger, Bordéus, Friburgo, Genebra, Monash-Austrália, Pretória; Rabat, Singapura...). Geralmente, estas cartas têm por objetivo regular a vida na universidade nomeadamente através do estabelecimento de códigos de comportamento (profissional e ético) a respeitar por todos os parceiros da instituição: administradores, investigadores, professores, estudantes, técnicos e pessoal administrativo e dos diversos serviços; mesmo quando certas universidades - como a norte-americana do Arizona - limitam a carta ética apenas ao comportamento dos estudantes. Esta evolução que começou em algumas instituições de formação jurídica e depois se estendeu a algumas universidades dos países da Europa e da América do Norte é doravante adotada em diversas universidades noutras regiões do mundo. 
Todavia, os estudos dos conteúdos das cartas éticas (por vezes designadas por "regulamentos ou códigos") de algumas universidades mostram que não há uma definição amplamente partilhada sobre o que é (deve ser) a ética universitária. Faz-se por vezes confusão entre moral e ética, entre deontologia ${ }^{2}$ e ética e por vezes observa-se uma vontade de reduzir a ética ao contributo de valores universalistas subentendidos por uma tradição religiosa. Há, pois, ainda necessidade de prosseguir a reflexão sobre a ética universitária e tirar partido das experiências adquiridas com a implementação das cartas éticas para melhor delimitar o campo da ética.

Seja como for, sendo a fraude considerada como um comportamento desviante, uma desonestidade, um não respeito das normas, promover a formação ética e impor a carta ética como fonte de referência dos comportamentos aceitáveis no seio da universidade significa incentivar professores e estudantes a não cometerem fraudes. A hipótese considerada pelos responsáveis é a de que, se o documento da carta explicita "as permissões e as proibições", ela pode contribuir eficazmente para reduzir a fraude daqueles (numerosos) que são culpados de comportamentos desviantes por ignorância.

E em relação aos outros - estudantes e professores investigadores - que praticam a fraude com conhecimento de causa? Relativamente a esses, a existência de uma carta não é suficiente, mesmo no caso de ela dever ser assinada pelo estudante para poder ser admitido na universidade. É preciso, sem dúvida, ir mais longe e obter uma adesão do pessoal ao conteúdo da carta, e assegurar-se de uma apropriação dos valores éticos. É por isso que, em certas instituições, é proposto

\footnotetext{
2 "Antes de mais, a deontologia é da ordem do direito. 'Ciência dos deveres' na origem, tornou-se, em França, direito positivo, codificação dos deveres que se impunham a uma profissão, a partir de 1947 com a criação do Código de deontologia médica. O direito profissional faz doravante parte integral do direito público. O Estado, através da lei - os decretos e o exame do Conselho de Estado - suscita, organiza, controla e garante a sua existência e a sua autonomia" (Obin, 1994).
} 
dar uma formação para a ética, insistindo no contributo da "reflexão ética que é suportada por uma disciplina técnica que se chama filosofia moral que tem os seus conceitos, os seus argumentos, os seus procedimentos de deliberação e de decisão" (Canto-Sperber apud Quinton, 2002, p.1). Em concreto, não se trata, como é evidente, de ministrar cursos de formação moral ou cívica: trata-se antes de sensibilizar os estudantes para a "ética da responsabilidade" no sentido que lhe é dado por Hans Jonas e até de ir mais longe, sensibilizando-os para "a ética de convicção", de acordo com a definição que lhe deu Max Weber: "é imperativo não praticar a fraude porque cada indivíduo se sente responsável em relação aos outros estudantes e em relação à universidade; e até mesmo não praticar a fraude porque não se deve praticar a fraude".

Apesar de um contexto cada vez menos favorável caracterizado por um sentimento difuso de que a sociedade dos nossos dias sofre de uma degradação do sistema de valores e de uma tendência para se fechar sobre si mesma, é possível constatar ao mesmo tempo a existência de numerosas iniciativas levadas a cabo por uma juventude empenhada em causas universalistas (tais como as que são sustentadas por organizações como a UNESCO, a UNICEF, a AICF etc.). Tal constatação permite-nos ter esperança de que a promoção dos princípios éticos pode encontrar ecos favoráveis junto da população estudantil. É interessante notar que um inquérito recente realizado em França sobre a fraude nos exames mostrou que a atitude dos professores e dos inspetores de educação face à fraude era relativamente tolerante enquanto os estudantes se mostravam bem mais rigorosos. O mesmo inquérito revela pelo contrário que, do ponto de vista dos estudantes, o plágio parece ser menos considerado como uma fraude grave, uma vez que entendem que a utilização dos resultados dos trabalhos dos outros faz parte do trabalho de investigação. A julgar pelo número de artigos vindos a lume em publicações especializadas (como The Times Educational 
Supplement), estas constatações apresentam-se como sendo passíveis de generalização a outros países.

Em síntese, as cartas éticas e as formações para a ética cobrem todos os domínios da fraude académica, mesmo quando se dá particular atenção à fraude aos exames e ao plágio. Ainda não estão disponíveis avaliações sistemáticas relativamente aos efeitos da adoção destas cartas nem relativamente à eficácia dos programas de formação para a ética levados a cabo por algumas faculdades de direito e pelas business schools. É verdade que a eliminação ou a redução da fraude obriga a pôr em prática de estratégias integradas que associem prevenção, vigilância/deteção e sanção (Hallak e Poisson, 2012).

\subsubsection{Vigilância, deteção das fraudes: gerir da melbor forma os ficheiros das universidades e as provas de exames}

Evitar as irregularidades nas inscrições supõe uma gestão rigorosa dos ficheiros dos estudantes (validação dos dossiers após a verificação dos documentos, teste de conformidade dando direito de acesso a tal ou tal programa, faturação e pagamento de eventuais direitos). Limitar as fraudes às provas de exame presume a elaboração de um guião detalhado de organização das provas (controlo da identidade à entrada na sala, presença de vigilantes, confidencialidade dos documentos das provas, acesso limitado ou proibido a fontes de informação na sala e fora da sala, etc...) e, consequentemente, o respeito pelas normas nele estabelecidas. Em certos países, apesar dos progressos observados nas administrações dos ministérios do interior, geralmente encarregados da emissão e gestão dos bilhetes de identidade [cartões de cidadão], as taxas de fraude no exame final do ensino secundário são muito elevadas porque a usurpação de identidade organizada em grande escala continua a ser um dos meios utilizados, dada a dificuldade de 
controlar a identidade. Garantir a originalidade de uma contribuição científica supõe nomeadamente que ela seja objeto de uma crítica e de uma avaliação por, pelo menos, três especialistas do campo científico abrangido; é o que fazem os responsáveis das revistas científicas para se protegerem dos riscos de plágio.

Estas abordagens clássicas de vigilância e de deteção foram consideravelmente melhoradas com o desenvolvimento e a implementação de programas (aplicações informáticas) suscetíveis de reforçar consideravelmente os meios de gestão dos ficheiros e sobretudo de detetar os plágios nos documentos entregues pelos estudantes (provas escritas de exame, relatórios de estágio, monografias, teses, etc.). É certo que os observadores constataram que as novas tecnologias favoreceram o desenvolvimento da fraude académica (Mazodier et al., 2012). A utilização dos smartphones, com a sua capacidade de armazenamento e de acesso à informação, constituiu (constitui ainda), de modo muito particular, um problema sério no que diz respeito à vigilância dos exames.

A fraude facilitada pela tecnologia gerou meios de prevenção adaptados. Não é suficiente, com efeito, proibir os $i$-phones e outros aparelhos similares que integrem telefonia, Internet, bases de dados e possibilidades de troca de mensagens entre grupos na sala de exame, pois não é possível garantir que um candidato não poderá dissimular um desses objetos e consultá-lo numa ida à casa de banho. Todavia, existem meios técnicos cada vez mais acessíveis para fazer face a este tipo de fraudes. A Inglaterra, a Coreia ou a China utilizam por exemplo portais detetores de metais, aparelhos de interferência de ondas ou ainda detetores permitindo revelar a presença de micros ou de ondas $w i$-fi. "A China pôs também em prática a utilização de dispositivos de video vigilância durante as provas do GaoKao. Embora este tipo de medidas coloque questões de liberdade individual e de direito à imagem, existe de certo modo uma extrapolação de um dos métodos de prevenção mais eficazes: 
o de dotar as provas de vigilantes atentos e em número suficiente" (Orientations, 2011).

A disponibilização de manuais, livros, tribunas de publicação de caráter científico etc. em linha, fez também disparar o plágio. Com os programas informáticos de tratamento de texto acoplados à Internet, plagiar, copiando passagens completas de textos ou documentos para os inserir no seu próprio texto (omitindo citar a fonte), torna-se quase um reflexo, uma prática corrente. Também a generalização do uso de aparelhos e suportes informáticos levou ao mesmo tempo ao aumento das oportunidades de fraude académica e à abertura de possibilidades de criar e desenvolver meios de as detetar e, por consequência, de as reduzir. Daí o desafio essencial que se coloca aos softwares antiplágio propostos: identificar os plágios com uma quase total certeza para impedir acusaçãos ilegítimas de plágio. Num estudo comparativo de softwares antiplágio, Olivier Duteille (2012) comparou dez softwares (Article checker, Copyscape, Compilatio, Duplicheker, Ephorus, Plagaware, Turnitin, Urkund, Viper, WCopyfind, etc.): as conclusões mostram um número crescente de softwares de fácil acesso ou mesmo gratuitos. Certos softwares são mais eficazes do que outros mas algumas pessoas que os põem em prática consideram que um recurso sistemático ao software antiplágio pode dissuadir os estudantes e os professores de praticar a fraude. Outros investigadores, professores e examinadores pensam que qualquer que seja a eficácia do software, é sempre possível evitar a deteção do plágio nas monografias de mestrados ou nas teses de doutoramentos mediante modificações "calculadas" dos textos de origem; para estes investigadores, professores e examinadores, o único método considerado válido é o controlo sistemático tradicional; recomendam o acompanhamento regular e assíduo por parte do tutor (orientador de tese) relativamente ao trabalho do estudante, acompanhamento que tem simultaneamente o objetivo de aconselhar e de acompanhar de perto os progressos do trabalho do estudante-investigador. 


\subsection{Sanções e penalidades: "um pau de dois bicos?"}

A opinião geralmente partilhada é a de que a simples publicação da proibição da prática de fraude nos regulamentos de exame e/ ou de uma universidade, mesmo quando acoplada a uma formação para a ética, não basta para impedir a fraude. É também necessário afixar e praticar uma bateria de sanções e penalidades para obter um efeito dissuasor e contribuir desse modo para a redução da fraude académica. De acordo com esta lógica, foram diversos os países que adotaram medidas para esse efeito ${ }^{3}$.

É um pouco isto que pode ser observado quando uma fraude é do interesse de uma personagem política ou quando existe um conjunto de provas que afetam vários candidatos. A pressão exercida pela opinião pública e sustentada pelos media leva geralmente a determinar sanções disciplinares, e/ou a perseguições de caráter judicial. Um grande número de exemplos recentes de plágio por parte de ministros (e de outras personalidades representativas da vida política) em certos países europeus e norte americanos levou à demissão das pessoas em causa. Do mesmo modo, atendendo a que afetam um grande número de candidatos, também as "fugas" de informação sobre os conteúdos e temas de exames tiveram como desfecho a anulação das provas e a perseguição penal dos presumíveis responsáveis por essas fugas.

Contudo, a experiência da China bem como de outros países mostra que a instituição e publicitação de um sistema de sanções e de penalidades não funcionam necessariamente como dissuasores.

\footnotetext{
3 Assim, por exemplo, a China adotou, há alguns anos, novas medidas que visavam a redução da fraude e do plágio no ensino superior. Numa circular publicada recentemente, a Comissão dos diplomas universitários do Conselho dos Assuntos do Estado enumera as sanções a aplicar aos estudantes culpados de fraude ou de plágio: relatório da entrega de um diploma; recusa de passar um diploma, revogação dos diplomas já obtidos; suspensão dos tutores e orientadores dos alunos fraudulentos; publicação dos resultados dos inquéritos sobre a fraude académica acompanhada da lista dos nomes dos prevaricadores; etc.
} 
Correndo o risco de exagerar na comparação, podemos ser tentados a citar aqui Benjamin Franklin: "Se as pessoas desonestas compreendessem as vantagens de ser honestas, tornar-se-iam honestas por desonestidade" (Brooks, 2011).

De acordo com o relatório Mazodier (2012), sobre a fraude nos exames em França, existe um arsenal jurídico (que remonta aliás ao século xix) que organiza as sanções disciplinares internas e chega mesmo a propor a via penal para os casos mais graves. No entanto, este arsenal é pouco utilizado. O mesmo relatório faz notar, com efeito, que por um lado os estudantes são raramente informados dos riscos de sanções disciplinares em que incorrem; e por outro lado, que não existe automaticidade entre a constatação da fraude cometida e a comunicação às autoridades competentes. Tolerância? (i) O mesmo acontece noutros países?; (ii) Como explicar a não aplicação das medidas consideradas dissuasoras?

(i) A tolerância perante a fraude varia provavelmente de acordo com o país. Não há informações estatísticas comparativas internacionais disponíveis que permitam documentar a primeira questão. Mas existem indicações parciais que parecem sugerir que um mesmo comportamento considerado desviante num determinado país não o é necessariamente noutro. Veja-se o caso da Dinamarca que autoriza, desde o ano 2010, o acesso à Internet em certos exames. Cada estabelecimento de ensino decide se os seus estudantes usam ou não o computador. É uma maneira de procurar informação e de a avaliar de forma crítica, defende o Ministério da Educação. Todavia, os professores fizeram notar a grande dificuldade de verificar se os jovens não comunicam entre eles durante as provas, via $e$-mail por exemplo (RTS, 2013). Nos Estados Unidos, pelo contrário, 92 oficiais da Força Aérea do exército americano - ou seja, quase metade de uma equipa de lançamento de armas nucleares pertencentes à base de Malmstrom - foram suspensos das suas funções por terem feito 
batota nos exames ao utilizar os smartphones durante as provas. Para as autoridades militares, tratou-se de um problema sistemático na cultura de uma equipa encarregada da gestão de mísseis balísticos (The Times of India, 2014). Pode finalmente supor-se que certas universidades preocupadas em privilegiar o acolhimento dos estudantes originários de certos países tenham tendência para "fechar os olhos" aquando da realização de testes de domínio linguístico.

(ii) O contributo dos sociólogos é pertinente para documentar a segunda questão. Assim, em primeiro lugar, aplicar uma sanção requer um trabalho suplementar que pode ser consequente (Mchawrab, Rouquet e Suquet, 2014) e isso pode ser dissuasor. Começar por "lembrar as regras", assegurar a vigilância de modo continuado, constatar objetivamente a fraude, produzir um relatório para justificar a sanção são ações que representam um esforço importante para desencorajar o favorecimento da tolerância. Em segundo lugar, existem hoje novos instrumentos de comunicação, tais como o telefone móvel e a Internet que, ao transformar os meios de praticar a fraude, modificaram também a perceção da fraude pelos diferentes protagonistas. Assim, de acordo com um relatório da Inspeção Geral sobre a avaliação na universidade em França em 2007 (Gauthier et al., 2007), existe um desvio importante de perceção do fenómeno da fraude: quando se interrogam os professores e o pessoal administrativo, verifica-se que há tendência para "minimizar" a fraude, enquanto que quando se interrogam os estudantes, a fraude é evocada de forma inquietante no que diz respeito aos exames realizados "em cima da mesa". No tocante à fraude por plágio na Internet, as apreciações são invertidas: os estudantes não estão convencidos de que se trata de um comportamento desviante enquanto para os professores e mesmo para a opinião pública o plágio é considerado como uma fraude caracterizada. Em terceiro lugar, de acordo com os trabalhos de certos sociólogos, a fraude é o resultado de um equívoco, de 
uma falta de comunicação entre os protagonistas do setor educativo. Na perspetiva de Anne Guardiola (apud Molénat, 2011), a fraude no ensino superior pode ser encarada como sendo o resultado de um "desconhecimento sistémico" entre estudantes e professores ${ }^{4}$. Dito de outro modo, a fraude permite encontrar o ponto de equilíbrio entre o que os estudantes procuram e o que lhes é oferecido pelos professores. Por analogia com o que fazem os economistas, poder-se-ia considerar que a fraude corresponderia ao ponto de interseção entre as duas curvas da oferta e da procura.

\subsection{Regular o funcionamento ou adaptar as finalidades e os méto- dos de ensino superior? Pistas para a reflexão}

Em resumo, parece que as ações políticas de luta contra a fraude académica baseadas no modelo (de tipo "transitivo") - informação, prevenção, vigilância/deteção, sanções/penalidades - não parecem funcionar e nem sempre dão resultados.

A informação pode ser eficaz junto dos prevaricadores desconhecedores dos códigos e das normas, do significado da fraude, das sanções aplicáveis e dos custos que a fraude pode ter para eles, para a sua instituição e para a sociedade. A formação ética e a adoção

\footnotetext{
4 "Os estudantes do primeiro ano que fazem exames consideram ser mal avaliados e incentivados a 'despejar a matéria dada nas aulas' quando gostariam que fossem tomados em consideração o seu empenhamento pessoal (seriedade, honestidade, sinceridade), a sua vontade (paciência, perseverança, esforço), a sua curiosidade... O exame é visto como uma prova aleatória (ausência de um barómetro de critérios de correção) relativamente à qual eles não dominam as regras o que os leva a recorrer ao 'copianço'. Os professores, por seu turno, investem pouco na tarefa de vigilância dos exames e pensam que isso deveria ser da responsabilidade da administração. Constata-se da sua parte uma certa distância relativamente a esse papel, distância essa evidenciada através de alguns sinais como: correção de testes, leitura, escrita, etc., sendo que cada um desses sinais é interpretado pelos estudantes como um sinal de indulgência. Por fim, o pessoal administrativo vê na fraude 'uma condenação, uma marca difamatória para o serviço organizativo da universidade'... e as fraudes, quando são averiguadas, não são nem divulgadas nem sancionadas." (Molénat, 2011)
} 
de códigos de conduta podem contribuir para a promoção de uma verdadeira cultura ética e favorecer a prevenção da fraude (Eckstein, 2003; Poisson, 2011). Isto pressupõe uma apropriação dos valores éticos pela comunidade universitária e implica que isso vá, por exemplo, para além do simples comprometimento (mediante assinatura), incentivando o respeito por uma carta de princípios da universidade em causa. Convém que cada um dos parceiros, estudantes, professores, investigadores, pessoal administrativo, aceite o princípio ético como fundamental para o sucesso da missão da universidade. As informações disponíveis permitem pensar que há ainda que fazer muitos esforços e que as experiências levadas a cabo por diferentes instituições (como é o caso do Juramento de Arquimedes adotado em 1990, com base no modelo do Juramento de Hipócrates, por um grupo de estudantes da Escola Politécnica de Lausanne EPFL, do qual constam as responsabilidades e os deveres de engenheiros e técnicos) devem ser saudadas e ao mesmo tempo avaliadas quanto ao seu impacto na melhoria dos nossos conhecimentos sobre a questão.

A vigilância conhece um período difícil, sobretudo por causa das oportunidades de fraude proporcionadas pelos smartphones e outros meios informáticos. A vigilância padece igualmente de um estatuto pouco invejável junto dos professores e do pessoal administrativo. Mas as consequências políticas das fraudes nos exames, que têm revelado uma organização deficiente da vigilância, têm levado certos países (como é o caso da China) a adotar medidas, por vezes extremamente severas, que fazem com que algumas pessoas não hesitem em denunciá-las como sendo atentatórias da liberdade individual. E, no entanto, como vigiar uma sala de exame - respeitando a dignidade dos candidatos - num tempo em que a miniaturização dos aparelhos informáticos torna cada vez mais fácil a obtenção de qualquer informação pertinente?

A deteção do plágio torna-se cada vez mais banal e fácil graças ao número crescente de softwares disponíveis (e muitas vezes gratuitos). 
Todavia, os professores chamam a atenção para o facto de que os softwares mais eficazes podem ser contornados por um estudante ou um investigador habilidosos e que a garantia de autenticidade do trabalho só pode ser assegurada por um enquadramento rigoroso e regular. Também em relação a este aspeto, devido ao facto de o rápido aumento da população estudantil não ser acompanhado de um crescente recrutamento de professores a um ritmo suficiente, observa-se que, em numerosas instituições, os estudantes de mestrado e os doutorandos não beneficiam do apoio intelectual a que teriam direito.

As sanções/penalidades podem, em teoria, ser sistematicamente aplicadas e tal acontece em certas instituições, sobretudo devido à pressão mediática quando a fraude atinge pessoas que ocupam funções políticas ou de representação, ou/ e quando a fraude interessa a um grande número de pessoas. Mas os inquéritos (infelizmente em pequena quantidade) deixam pensar que tanto as instituições como os elementos do corpo docente preferem evitar o lançamento dos procedimentos que dão azo a uma sanção e/ou uma condenação: receio pela reputação da instituição? Peso do procedimento que leva à rejeição? Tradição de tolerância alimentada pelo sentimento de que a fraude significa de certo modo o insucesso do professor e da instituição? Sem dúvida. Mas há talvez outros fatores que levam a não recorrer à sanção fazendo com que a reflexão necessária ao conhecimento dos bloqueios relativamente às decisões de sanções a aplicar continue por fazer.

Ao fim e ao cabo, podemos perguntar-nos se o modelo "transitivo" (informar, vigiar, punir) contribui realmente para a regulação do sistema. No fundo, podemos perguntar-nos se o desafio a enfrentar não é sobre-humano: tratando-se da procura de um irresistível e quase impossível equilíbrio entre os custos éticos, sociais, pedagógicos e económicos da luta contra a fraude e dos custos, da mesma natureza, de políticas de "laissez faire", de tolerância e de ausência 
de intervenções dos poderes públicos. Será talvez necessário interrogarmo-nos sobre a fragilidade de certas hipóteses subjacentes ao modelo transitivo. Os elementos a seguir apresentados, que não constituem recomendações, visam apenas traçar algumas pistas de reflexão:

1) Sobre o caráter cumulativo da fraude nos exames. Correndo o risco de simplificar, a experiência parece mostrar que "quem prevaricou voltará a fazê-lo". A esse respeito, um inquérito recente (2009) mostrou que "A intensidade da fraude nos exames depende fortemente da experiência já adquirida neste domínio" (Guibert e Michaut, 2009). Quem fez batota no básico ou no secundário vai continuar a fazê-lo de forma sistemática na universidade; sem dúvida, porque a experiência lhe terá mostrado que os riscos que se correm ao fazê-lo são fracos e que as vantagens podem ser reais. Isto sugere que a luta contra a fraude no ensino superior deve começar no ensino básico ou mesmo no primeiro ciclo;

2) Sobre a oportunidade de deteção das fraudes 5 . Dado o custo e os limites da eficácia da vigilância e tendo em conta a fragilidade das técnicas de deteção, podemos perguntar se não seria conveniente encarar a possibilidade de "socializar" a vigilância, procurando formas de mutualização. Estas abordagens que ainda é preciso experimentar e afinar são já aceites por equipas de investigação, como é possível confirmar através das publicações que validam os resultados; ("Fala-se de uma experiência levada a cabo com sucesso por uma equipa dirigida pelo senhor ou pela senhora $\mathrm{X}$ ). Se nos inspirarmos nas práticas de pesquisa, talvez fosse igualmente necessário prever que os exames fossem realizados em equipa; complementados com

\footnotetext{
5 De acordo com a ACFE (Association of Certified Fraud Examiners, Inquérito 2006), a primeira fonte de deteção da fraude era a denúncia $(34,2 \%)$, depois o acaso $(25,4 \%)$, a auditoria interna $(20,2 \%)$ e o controlo interno $(19,2 \%)$.
} 
interrogações orais individuais. Pode, por outro lado, adotar-se o princípio de que na entrega de monografias de estágio, de teses ou outros relatórios escritos seja permitido anexar os resultados de testes anti plágio ou/e relatórios de avaliação de painéis de "pares". Relembramos que se trata aqui mais de pistas de reflexão do que de recomendações.

3) Seguindo a mesma ordem de ideias, podemos interrogar-nos se não será necessário tentar confiar a responsabilidade da verificação de conhecimento a entidades independentes da instituição universitária. É provavelmente mais fácil admitir que, em caso de fraude, as entidades independentes da instituição universitária se sintam mais livres para aplicar as sanções, evitando assim aos professores e aos estudantes a incursão no "risco de conflito de interesses" no decurso dos exames. É, de certo modo, o tipo de abordagem utilizada na acreditação dos cursos de instituições de formação. A experiência mostrou, no entanto, que os riscos reais de fraude afetam os próprios procedimentos de acreditação e a pergunta que surgiu na sequência disso foi: "Quem acredita os órgãos de acreditação?". Pode observar-se que também aí a reflexão deve continuar a procurar formas de neutralidade e de autonomia das entidades encarregadas da verificação de conhecimentos.

4) sobre a certificação mediante os exames: regressar às finalidades de base da educação. Relembremos aqui os quatro objetivos atribuídos pela Unesco à educação (Faure, 1972): "aprender a ser, aprender a viver com os outros, aprender a aprender e aprender a fazer". Geralmente, os exames não contemplam os dois primeiros objetivos porque eles só podem ser avaliados posteriormente à conclusão dos estudos, na vida pessoal e social; é evidente que a avaliação dos resultados relativamente aos dois primeiros objetivos ultrapassa, em parte, a questão da fraude académica de que é objeto este texto; 
apenas em parte, porque a questão ética é central no que diz respeito a estes objetivos e trabalhar para os atingir pode contribuir para a redução da fraude. Pelo contrário, pode considerar-se que o terceiro e o quarto objetivos estão no centro das nossas preocupações.

A este respeito, tratando-se do terceiro objetivo (aprender a aprender), pode estimar-se que a abordagem "à dinamarquesa" se adapta à avaliação dos resultados. Com efeito, no mundo atual, em que os dados e a informação sobre o saber e o conhecimento estão em livre acesso, e muitas vezes de forma gratuita, pode pensar-se, como acontece na Dinamarca, que o mais importante é que os estudantes saibam procurar na Internet, de modo crítico e seletivo, as informações e que sejam capazes de as utilizar adequadamente. Neste caso, o objetivo de base é aprender a procurar na net as informações, ser capaz de as organizar em saber, transformá-las em conhecimento. Assim, ações consideradas fraudulentas deixariam de o ser. O exame terá como finalidade controlar o modo como os estudantes procedem em vez de verificar o que eles memorizaram.

Se, em contrapartida, considerarmos que é também preciso ter em conta o quarto objetivo da educação definido pela UNESCO ("aprender a fazer"), então o importante já não seria apenas procurar a informação relevante e fazer dela um saber. O objetivo da formação é poder aplicar o saber de adquirir capacidades. Nesse caso, os exames já não visam tanto controlar os conhecimentos - aliás o caso mais fácil de levar à fraude, como vimos - mas sobretudo avaliar as competências adquiridas - a capacidade de fazer, de agir, mas também de pensar, etc., tudo domínios sobre os quais é muito mais difícil de exercer a fraude. Com efeito, a verificação de competências, contrariamente à verificação de conhecimentos, não é "declarativa". Não basta dizer "eu sei"; é preciso mostrar que se sabe.

As consequências para as finalidades, os conteúdos e os métodos de ensino superior são importantes; sem ter isso em conta, será difícil direcionar a questão da fraude académica. Os responsáveis pelas 
instituições tomam consciência de que é imperativo mudar os métodos e os conteúdos. Foi possível constatar, por exemplo, a vantagem da alternância nas instituições que têm altos níveis de qualificação: por exemplo os dos masters em França. Assim, para Nathalie DrachTemam, Vice-Presidente da Universidade Pierre e Marie Curie (UMPC) "a alternância constitui uma modalidade pedagógica particular que permite ao estudante aplicar diretamente o que aprendeu" (citado em L'alternance, le must ${ }^{6}$ ). (Lewandowski, 2014).

Na sua totalidade, a problemática "ética e fraude académica" faz apelo a uma estratégia integrada que não se contenta com "o modelo transitivo" e que implica, sem dúvida, adaptações dos objetivos, dos métodos e das modalidades de organização da oferta de formação a nível superior.

\subsection{Referências bibliográficas}

Bouquet, B. (2009), La responsabilité, entre philosophie, éthique et droit. Revue Vie Sociale, 3, CEDIAS, Musée social.

Brooks, F. (2011), Quel est votre niveau d'éthique? Obtido em 23 de março de 2014 em http://www.philo5.com/Cogitations/110129QuelEstVotreNiveauEthique.htm

Duteille, O. (2012), Comparatif logiciels anti-plagiat (Logiciels conçus pour détecter les documents plagiés sur Internet). Obtido em 27 de março de 2014 em https:// webcampus.univ-pau.fr/fichiers_webcampus/divers/Logicielsantiplagiat.pdf

Eckstein, M. A. (2003), Combating Academic Fraud. Towards a Culture of Integrity. Paris: Unesco - International Institute for Educational Planning.

Faure, E. (1972), Apprendre à être. Paris: Unesco.

6 Na Alemanha, há muito que se vem favorecendo a alternância (o sistema dual), simultaneamente porque era preciso dar uma formação sobre o ambiente concreto do mundo do trabalho (e, para certos especialistas, da ética do trabalho) (Bouquet, 2009) e para "formar para fazer". 
FMPOS (2013), Le Ministre Dicko répond le General Doua. Obtido em 17 de abril de 2014 em http://www.fmpos.net/index.php/actualites/43-le-ministre-dicko-repond-le-general-doua

Gauthier, R.-F.; Caffin-Ravier, M.; Descamps, B.; Mosnier, M. e Peretti, H. (2007), L'évaluation des étudiants à l'Université: Point aveugle ou point d'appui? Paris: Ministère de l'Education Nationale. Relatório 2007-072, julho da Inspection générale de l'administration de l'Éducation nationale et de la Recherche. Obtido em 29 de março de 2014 em http://media.education.gouv.fr/file/65/5/6655.pdf

Guibert, P. e Michaut, C. (2009), Les facteurs individuels et contextuels de la fraude aux examens universitaires. Revue française de pédagogie, 169, pp. 43-52.

Hallak, J. e Poisson, M. (2012), Mapping distorted practices in higher education. Corruption Research Forum. Moscovo, 26 de setembro.

Lewandowski, J.-C.; (2014), Le master en alternance, un must. Le Monde - Education, edição de 21 de janeiro. Obtida em 4 de maio de 2014 em http://www.lemonde. fr/education/article/2014/01/21/1-alternance-le-must_4351950_1473685.html

Mazodier, M.; Blemont, P.; Foucault, M. e Kesler, S. (2012), La fraude aux examens dans l'enseignement supérieur. Rapport de l'Inspection générale de l'administration de l'éducation nationale et de la recherche en France, Relatório 2012-027, abril.

Mchawrab, S; Rouquet, A. e Suquet, J. B. (2014), Les institutions académiques face aux comportements déviants de leurs étudiants: le cas d'une business school française. Gérer et Comprendre, 115, pp. 41-53.

Molénat, X. (2011), La triche aux examens: fraude ou incompréhension? Sciences Humaines, 15 de junho de 2011. Obtido em 2 de maio de 2014 em http:// www.scienceshumaines.com/la-triche-aux-examens-fraude-ou-incomprehension_fr_22770.html

Obin, J. P. (1994), Les enseignants entre morale, éthique et déontologie. Education et management, fevereiro. Obtido em 29 de março de 2014 em http://www. jpobin.com/pdf8/1994lesenseignantsentremorale.pdf

Orientations (2011), Examens: comprendre et agir contre la fraude. Orientations, 4 de julho. Obtido em 23 de março de 2014 de http://www.e-orientations.com/ actualites/examens-comprendre-et-agir-contre-la-fraude-8237 
Pech, M-E. (2010), 70 \% des élèves trichent pendant leur scolarité. Le Figaro. Obtido em 26 de abril de 2014 em http://www.lefigaro.fr/actualite-france/2010/06/28/ 01016-20100628ARTFIG00678-70-des-eleves-trichent-pendant-leur-scolarite.php Poisson, M. (2011), Lignes directrices pour l'élaboration et l'utilisation efficace des codes de conduite des enseignants. Paris: Série de l'IIPE sur l'Ethique et la corruption dans l'éducation.

Quinton, A. (2002), Des manquements à l'éthique dans l'enseignement universitaire en France. Relatório de um colóquio realizado na Université Victor Segalen Bordeaux 2, em junho de 2001.

RTS (2013), Tour du monde de la triche aux examens scolaires et universitaires. Radio Television Suisse - Info. Obtido em 25 de março de 2014 em http://www.rts. ch/info/monde/4982393-tour-du-monde-de-la-triche-aux-examens-scolaires-et-universitaires.html

The Times of India (2014), Exam fraud: US suspends 92 N-officers. The Times of India - US, edição de 1 de fevereiro. Obtido em 12 de abril de 2014 em http:// timesofindia.indiatimes.com/world/us/Exam-fraud-US-suspends-92-N-officers/ articleshow/29687202.cms?

Universidade de Genebra (2013), Plagiat à l'université — L'université se présente-UNIGE. Obtido em 3 de maio de $2014 \mathrm{em}$ http://www.unige.ch/apropos/politique/ plagiat/edudiants.html. 


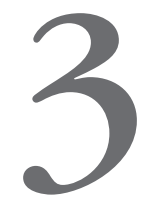

PARA QUE NÃo SE CONFUNDA A GESTÃo DO PLÁGIO ESTUdANTIL COM QUESTÕES DE ÉTICA, FRAUDE E LUDÍBRIO:

\section{O QUE NOS ENSINA A EXPERIÊNCIA DO ENSINO SUPERIOR EUROPEU}

Jude Carroll

Consultora em desenvolvimento educativo

bttp://dx.doi.org/10.14195/978-989-26-1123-5_3 
(Página deixada propositadamente em branco.) 


\subsection{Introdução}

É crescente, um pouco por toda a Europa, o interesse pelo plágio estudantil e pela sua gestão nas instituições de ensino superior, porventura fomentado pelo recurso também crescente às tarefas da componente letiva (por vezes designadas trabalhos escritos, ou simplesmente 'trabalhos', ou ainda avaliação fora da aula). O plágio começa a ser encarado como algo de importante a partir do momento em que o trabalho produzido pelos estudantes se traduz em notas e em créditos. Essa tomada de consciência é também frequentemente desencadeada pelo uso crescente do inglês. Estes são fatores passíveis de conduzir à adoção de medidas em universidades que ainda não tenham criado ou aplicado políticas de gestão do plágio. Tem-me igualmente sido possível observar que essa preocupação crescente está a fazer com que certas instituições, em que as políticas já foram criadas mas ficaram na prateleira, estejam agora, finalmente, a passar à prática. As universidades que até agora não encararam o plágio estudantil como uma prioridade precisam de o fazer, e o presente capítulo propõe-se ajudá-las a caminhar nessa direção.

Começarei por definir plágio, ludíbrio e fraude, refletindo com algum pormenor sobre aquilo que cada um destes termos quer dizer e também sobre o que não quer dizer. O leitor poderá achar esta minha reflexão despropositada - será que quem concebe e quem aplica as políticas precisa mesmo de pensar a definição de plágio e de ludíbrio com todo este pormenor? Porém a experiência ensinou-me que é geral a confusão existente em torno destes três conceitos, e que, quando ela existe, os mal-entendidos são passíveis de travar 
ou desviar os esforços no sentido da sua gestão eficaz. Um equívoco comum é considerar que todo o plágio constitui ludíbrio, ou 'batota'

De seguida farei o elenco dos aspetos que constituem uma política eficaz e eficiente de gestão do plágio estudantil, baseando-me para isso principalmente em bibliografia do contexto universitário anglófono. Enunciarei também alguns procedimentos para lidar com os casos de possível ocorrência de plágio, ludíbrio e fraude estudantis. O objetivo é a elaboração de políticas realistas e a concretização de procedimentos que sejam justos, defensáveis e coerentes na sua aplicação. Dos procedimentos, uma vez adotados, exige-se que sejam capazes de gerir quantidades relativamente elevadas de casos, que constituam um elemento normal da rotina académica, que sejam aplicados por um corpo docente já de si muito ocupado, que sejam sustentáveis num momento em que as universidades tanto carecem de recursos, e que consigam competir com inúmeras outras prioridades institucionais. Um conjunto bem exigente de condições, portanto.

Para melhor poder apoiar as instituições na adoção de políticas e procedimentos eficazes, o artigo termina com uma descrição do sistema do ACO - Academic Conduct Officer ${ }^{8}$. O sistema já se encontra em vigor em muitas universidades de todo o mundo e tenho conhecimento de que a cada dia há inúmeras outras a adotá-lo. Ao cabo de mais de uma década de utilização e avaliação, o sistema ACO (ou algo equivalente) deu provas de ser uma componente eficaz da gestão holística dos fenómenos de plágio e ludíbrio estudantis. Possuir ACOs, por si só, não resolve problema nenhum. A introdução do sistema é, por norma, acompanhada de procedimentos em que tanto docentes como estudantes confiam, que entendem e que veem que se poderão traduzir em penalizações justas e coerentes em caso de infração dos regulamentos académicos. Tenho verificado, por parte dos docentes, uma resistência

7 Em inglês, cheating. [N.T.]

8 Gabinete, ou responsável, para a conduta académica. [N.T.] 
cada vez menor a lidar com a gestão do plágio. A conclusão que daí retiro é que a utilização de um sistema como o ACO poderá funcionar como catalisador para uma aposta crescente nessa gestão.

\subsection{Distinções necessárias}

Defendo, como ponto de partida, que gerir o plágio na universidade é diferente de ter de o fazer fora dela. No seio da universidade o plágio deve ser encarado, fundamentalmente, como um problema do âmbito da aprendizagem. O plágio e a aprendizagem interligam-se de duas maneiras:

Problema de aprendizagem 1.) A maioria das universidades europeias rege-se por teorias da aprendizagem vulgarmente designadas por construtivistas. A teoria construtivista da aprendizagem parte do pressuposto de que o estudante não aprende apenas quando se defronta com, recolhe, ou replica ideias; ele aprende quando as compreende por si próprio e as domina. Do estudante que se rege por um paradigma construtivista da aprendizagem ou que trabalha em ambiente de investigação espera-se que aplique os conhecimentos adquiridos, dando mostras de que os domina. É através da utilização das ideias e da sua transformação que o estudante faz prova de que apreende. Compete-lhe igualmente ir beber às ideias de outrem para assim construir os seus argumentos e/ou achar soluções para os problemas. O plágio, enquanto algo que implica copiar, apropriar-de de, ou reciclar as ideias de outrem, rompe a conexão existente entre o esforço laborioso' ${ }^{9}$ a aprendizagem, e os créditos ou outro benefício académico.

\footnotetext{
9 O 'esforço laborioso' a que me refiro consiste na utilização e na devida sinalização, de uma maneira transparente, do trabalho de outros. Trata-se de uma forma de proceder que está longe de ser fácil ou óbvia, e que não é gerida do mesmo modo de uma universidade para outra.
} 
Problema de aprendizagem 2.) O estudante precisa de aprender a utilizar e a valorizar as convenções e as práticas pedagógicas em vigor no seio das universidades. Quando chega à universidade, a maior parte dos estudantes não traz consigo o conhecimento e as competências necessários para compreender e acatar os regulamentos e as exigências inerentes à integridade académica.

O lugar fulcral que a aprendizagem ocupa na gestão do plágio estudantil significa que há que continuar a centrar a atenção nas questões da acreditação e da garantia de qualidade. As universidades devem evitar deixar-se influenciar excessivamente pelo debate público em torno do plágio, tão comum entre jornalistas e comentadores, e tão inflamado e viciado por vezes. Fora do contexto universitário, a presunção de que o plágio implica sempre fazer juízos morais acerca da pessoa que plagia pode ou não ter cabimento (pessoalmente tenho, sobre o tema, ideias assentes, que no entanto saem do escopo deste artigo). No interior da universidade, associar o plágio a integridade revela-se, as mais das vezes, inadequado. A tentativa de compreender a lógica das infrações estudantis aos regulamentos tem, frequentemente, muito menos a ver com juízos sobre o perfil moral dos estudantes do que com o facto de estes não terem ainda interiorizado a cultura da universidade e das suas normas e de ainda não terem adotado as convenções universitárias relativas à utilização e devida sinalização do trabalho alheio (Blum, 2007; Sutherland-Smith, 2010).

\subsubsection{Distinção entre plágio e ludíbrio}

De entre as definições de plágio prefiro a de Teddi Fishman, Diretora do Centro Internacional para a Integridade Académica, sediado nos EUA. Segundo Fishman, o plágio ocorre quando alguém: 
- apresenta trabalho(s) ...

- de uma fonte nomeada ou identificável ...

- numa situação em que se espera trabalho original ...

- sem que haja uma suficiente sinalização da fonte ...

- para obtenção de créditos ou outro benefício próprio (Fishman, 2009).

Repare-se que, apesar de o nome do Centro de Fishman aludir a integridade, o mesmo não sucede com a definição de plágio proposta pela autora. Com efeito, a definição de Fishman fixa cinco condições que terão, todas elas, de estar presentes para que se possa responder à pergunta: Este trabalho contém plágio? Um trabalho que ostente alguns dos critérios mas não a sua totalidade não poderá ser considerado plágio. Assim, e por exemplo, poderá dar-se a circunstância de um estudante apresentar, para efeito de obtenção de créditos, material copiado, mas numa situação em que a originalidade ${ }^{10}$ não constitua um requisito. Será esse o caso, por exemplo, de um professor que dê como trabalho de casa uma pergunta de natureza factual ('De que modo é que o pâncreas contribui para o metabolismo do açúcar?'), quando a resposta consta do manual de apoio do curso. Se o estudante apresentar um trabalho de casa copiado do manual, ter-se-á tratado, em minha opinião, de uma má prática da parte do docente que ordenou a tarefa, da qual pouca ou nenhuma aprendizagem advirá, provavelmente, para o estudante. Contudo o trabalho por este apresentado não constitui, em si mesmo, plágio. E o motivo por que não é plágio é que estamos perante uma situação em que não se exige originalidade, além de que o trabalho finalmente apresentado (i.e., a resposta) não é algo que seja pertença de uma pessoa ou de uma fonte identificada. $O$ trabalho poderia ser

\footnotetext{
10 Note-se que a palavra 'original' não pretende designar um produto novo, exclusivo daquele aluno, ou algo de inteiramente inaudito, mas tão somente referir o ato que lhe deu origem. Ou seja, o que está em causa é o produto resultante do pensamento, esforço e ação do estudante.
} 
melhorado se fornecesse a referência bibliográfica, revelando a autoridade da fonte e a eventual atualidade da publicação que contém a resposta; tal permitiria que o docente verificasse o grau de rigor, etc. - mas essa é uma outra questão.

Eis outro exemplo de um trabalho que preenche alguns mas não todos os requisitos para que possa ser considerado plágio: Um estudante de doutoramento usa os dados e as ideias de alguém que não identifica, transcrevendo uma sequência de dez ou doze palavras do original em que a ideia vinha expressa, mas sem chegar, propriamente, a indicar a referência bibliográfica no corpo do texto - como por exemplo (Wilson, 1998: 32). No entanto, o doutorando menciona Wilson na sua tese, deixando claro que é a esta autora a que se devem as ideias e referindo-se, inclusivamente, à época em que a obra foi publicada ('...há mais de dez anos'). Ora esta utilização da obra de Wilson é inaceitável numa tese de doutoramento, porém não configura plágio, uma vez que foi sinalizada. A utilização correta traria um acréscimo de qualidade e, neste caso concreto, haveria que usar aspas e uma referência efetiva para mostrar que o autor da dissertação é competente no uso que faz das palavras alheias. Contudo as aspas e a referência explícita não constituirão uma necessidade absoluta como proteção contra o plágio se o autor se encontrar inserido num contexto em que a palavra plágio é devidamente entendida. ${ }^{11}$

Um terceiro exemplo: Um estudante apresenta, em versão preliminar, um documento do qual $80 \%$ é cópia direta, sem que no entanto forneça qualquer indicação da fonte nem qualquer sinalização de que houve utilização das palavras de outrem. Tal prática é inaceitável e

\footnotetext{
11 É de uma forma muito deliberada que recorro a este exemplo, porque o Diretor do Office of Independent Adjudicators, no Reino Unido, se referiu a um caso exatamente idêntico; ou seja, em que uma estudante de mestrado copiou 11 palavras de uma determinada fonte sem fazer qualquer menção à respetiva proveniência, com o resultado de que a universidade propôs reprovar-lhe a dissertação por motivo de plágio e recusar-lhe créditos pelo trabalho desenvolvido ao longo de todo o ano letivo (Deech, 2006). A estudante recorreu, desafiando a comunidade académica a rever os procedimentos relativos a penalizações, o que, por sua vez, conduziu ao projeto AmBer, a que adiante farei referência.
} 
merecedora de comentário que o afirme de forma inequívoca ('Isto será plágio se...'), alertando para as consequências caso o autor ou autora não proceda, antes da apresentação final, a alterações em conformidade com aquilo que são os requisitos vigentes com respeito a referenciação bibliográfica. O estudante irá necessitar de orientação específica com vista a compreender e saber interpretar os comportamentos inerentes à aprendizagem construtivista. Todavia, o trabalho, neste estádio, não é plágio, uma vez que ocorreu numa primeira versão; ou seja, ainda não foi submetido para efeito de obtenção de nota ou créditos.

Em resumo, para se determinar a ocorrência ou não ocorrência de plágio há que ter em consideração as indicações presentes no próprio trabalho em apreço, o contexto, e ainda o significado, em termos académicos, de que o ato do estudante se reveste. Determinar a ocorrência de plágio não implica emitir juízos sobre as motivações do estudante ou sobre as razões do seu comportamento. Mas a fixação de penalizações ou de consequências já implica, efetivamente, que se façam juízos quanto à gravidade (indagando, por exemplo, 'Qual o nível de gravidade deste plágio?'). Um dos critérios para aferir a gravidade é a circunstância de o trabalho em causa poder contar - ou não - para a obtenção de créditos. As penalizações e as consequências obrigam ainda à formulação de juízos sobre a intenção, incluindo juízos sobre a ocorrência ou não ocorrência de ludíbrio.

\subsubsection{Definição de ludíbrio}

O ludíbrio é difícil de definir, mas para que um comportamento seja considerado ludíbrio tem de haver algo mais do que a demonstração de que ocorreu uma infração das regras da universidade. Por norma, o ludíbrio implica que aquele que ludibria busque benefício de uma maneira desleal. É evidente que existem formas de ludíbrio 
que não envolvem plágio. Assim, os estudantes que recorrem ao ludíbrio poderão, por exemplo, levar para os exames telefones escondidos, levar as respostas escritas nos braços, conseguir previamente as perguntas de um teste, inventar mentiras sobre doenças de familiares, etc. No contexto do plágio, o ludíbrio implica que haja uma tentativa deliberada de contornar ou evitar o esforço laborioso a que a compreensão e devida sinalização do trabalho de outrem obriga. Aquele ou aquela que ludibria esconde os seus atos, tentando criar no avaliador uma impressão falsa. Quando o estudante ludibria através do recurso ao plágio, está a tentar obter créditos por uma aprendizagem que não fez e benefícios de que não é merecedor.

\subsubsection{Plágio, ou ludíbrio com recurso ao plágio?}

Há casos de plágio que não configuram ludíbrio, e são muitos os autores que defendem a necessidade de destrinçar um do outro. Vejase, por exemplo, Ashworth, Freewood e Macdonald (2003); Partridge e West (2003); Hunt (2004); Blum (2007); Yeo e Chein (2007); Howard (2008); de Lambert, Ellen e Taylor (2006), entre muitos outros. Diversos estudos mostram que o ludíbrio não ocorre senão numa minoria de casos. Um estudo australiano (Martin e Haeringen, 2011), por exemplo, analisou o trajeto dos casos ocorridos no seio de uma universidade ao longo de quatro anos, concluindo que três quartos dos casos de plágio justificavam uma 'resposta educativa'. McGowan (2005) defende com solidez esta ideia no caso de estudantes internacionais que utilizam o inglês como língua adicional. Na minha universidade, onde durante mais de uma década procedemos à gestão planeada e ao registo de muitos milhares de casos, apurámos que em cerca de metade destes se impunha a hipótese de se tratar de infração dos regulamentos académicos por parte do estudante, mas sem tentativa de obtenção de benefício injusto. Por outras palavras, em cerca de metade dos casos 
os estudantes plagiaram mas não ludibriaram. A minha experiência empírica de conversas com centenas de professores a quem, um pouco por todo o mundo, tenho feito perguntas sobre esta questão vai no mesmo sentido (embora alguns - com base numa evidência igualmente empírica e pontual - tenham uma visão acentuadamente diversa, achando que a maioria dos estudantes recorre ao ludíbrio).

Por norma, a ocorrência de plágio sem ludíbrio dá-se devido a uma falta de consciência e/ou de competência e/ou à circunstância de a quantidade de texto ou informação copiada ou não referenciada ser tão reduzida que não tem qualquer reflexo sobre a capacidade do trabalho submetido para demonstrar o saber do estudante. Ou seja, não deixa de ser plágio e não deixa de precisar de ser tratado como tal. Conheço muitas situações em que o plágio não é tratado como plágio - em que o professor porventura se limita a atribuir uma nota baixa ou a dizer aos estudantes para serem mais cuidadosos nos trabalhos, no que respeita à inclusão de referências. Quando tal sucede, o estudante não só não aprende qual o uso correto como acaba por perder a oportunidade de dominar as competências pedagógicas relacionadas com a referenciação (Bretag et al., 2011). Alguns estudos apontam para a ideia de que a tolerância e a opção por não chamar o plágio pelo nome correto poderão acentuar nos estudantes, ao invés de a diminuir, a propensão para o plágio e para cometer infrações ainda mais graves no futuro (Whitely e Keith-Spiegel, 2002; Walker, 2010).

\subsubsection{As complexidades do mal-entendido}

O mal-entendido é algo de complexo. Bretag et al. (2011) fazem notar que o estudante pode compreender o sentido da palavra 'plágio' (se bem que a evidência revele que tal não é o caso, mesmo quando o estudante afirma ter compreendido) sem que, no entanto, consiga aplicar esse conhecimento na prática. 
O mal-entendido processual (quer dizer, a ignorância sobre 'como' funciona o plágio) ocorre, frequentemente,

- quando o estudante muda de área disciplinar, defrontando-se com novas expectativas;

- quando o estudante esteve algum tempo afastado do ensino superior, visto que as normas respeitantes à referenciação bibliográfica se tornaram bem mais apertadas nesta última década;

- quando existem diferenças significativas entre as normas atuais e as precedentes no que à elaboração de trabalhos individuais diz respeito. Tal pode ocorrer no caso de estudantes oriundos de setores com uma prática profissional própria, com estudos feitos noutros países, e/ou provenientes de escalões inferiores de ensino. Neville (2009) documentou esta situação quando interrogou estudantes de pós-graduação estrangeiros a propósito da sua experiência de adaptação às práticas de referenciação bibliográfica em vigor no Reino Unido, tendo apurado que $25 \%$ dos 255 estudantes inquiridos declararam que não sentiram quaisquer dificuldades quanto ao plágio no decurso dos respetivos estudos, uma vez que as expectativas com que depararam no Reino Unido eram as mesmas que havia 'nas suas terras'. Outros $25 \%$ afirmaram não ter sido problema a mudança para as expectativas encontradas no Reino Unido, e $50 \%$ referiram ter passado por 'uma transição radical ao nível educativo e social' (p.1). Metade dos inquiridos disse-se confusa e "profundamente preocupada com as questões de plágio' mesmo após vários meses de ensino intensivo. É raro os estudantes terem a noção de que se vão confrontar com uma mudança dos requisitos quando transitam de um dado quadro de práticas pedagógicas para outro, geralmente num país diferente (Gu, Schweisfurth e Day, 2012); 
- quando o estudante, ao matricular-se, traz consigo pouca ou nenhuma experiência de escrita autónoma, de busca e utilização das fontes, ou de passar as suas ideias a escrito de uma maneira clara (Davis, 2013). Na bibliografia sobre o ensino de estudantes de mobilidade é comum observar estudantes surpresos ou mesmo chocados com as novas exigências com que se confrontam (Carroll, no prelo);

- quando o estudante participa num programa em que não esperava ter de escrever. Há professores de arquitetura, matemática, engenharia e belas-artes (entre outros) que falam do choque de estudantes seus ao descobrirem que, para além dos conhecimentos e competências na própria disciplina, têm de dominar a escrita académica.

Não sendo exaustiva, a lista justifica que se parta do princípio pragmático de que, independentemente da sua prévia experiência ou formação, todo o estudante precisa que lhe ensinem as suas responsabilidades quanto à utilização e sinalização do trabalho alheio. Ensinar competências é mais eficaz do que acenar com ameaças por motivo de ludíbrio (Sutherland-Smith, 2010).

\subsubsection{Os estudantes que não seguem as normas depois de compreendidas}

A própria transição para novos patamares de compreensão e de competência remete para a necessidade de um sistema que, sendo flexível e baseado em juízos formulados caso a caso, não deixe de ser coerente. Tal implica que haja um sistema de penalizações e que estas sejam ajustadas à gravidade das infrações, incluindo as mais ligeiras. Quanto às consequências, poderão assumir a modalidade de uma conversa com o docente, destinada a reforçar os requisitos 
pedagógicos, e devidamente gravada por forma a impedir que o estudante possa vir, posteriormente, a fazer-se de inocente. Poderá ser também a obrigatoriedade, para o estudante, de se submeter a um acompanhamento tutorial online. Nalguns casos a penalização poderá ser a correção e reapresentação do trabalho (embora muitas vezes esta medida signifique uma penalização principalmente para o professor e tenda a não ser sustentável).

A destrinça entre plágio e ludíbrio, aliada ao reconhecimento de que o plágio pode ocorrer com níveis diversos de gravidade, significa que irão, forçosamente, colocar-se casos graves de irregularidades no que respeita à conduta académica.

\subsubsection{Identificação dos casos de infração grave}

Para que um caso seja considerado uma infração académica grave, o decisor terá de dar por provado que o estudante conhece as normas e convenções da referenciação bibliográfica; que possui competência bastante para as respeitar; e que existe fundamento para se concluir que procurou deliberadamente contornar o esforço laborioso a que o respeito pelas normas obriga. Entre os exemplos de infração grave estará o caso daquele estudante que, embora conhecedor das normas relativas à utilização da citação literal, recorra à cópia sem fornecer a mínima indicação de que o texto constitui uma apropriação ipsis verbis das palavras de outrem. A infração grave assume contornos mais acentuados quando o texto copiado constitui uma porção significativa do todo que suporta a pretensão, por parte do estudante, à obtenção de créditos. A infração torna-se ainda mais grave quando o estudante procura deliberadamente fazer com que o material de que se apropriou pareça seu ou quando procura deliberadamente gerar no avaliador uma impressão falsa quanto à efetiva autoria do trabalho apresentado. Ou seja, o estudante poderá, por exemplo, retirar da 
web uma quantidade significativa de texto acerca do [tema $\mathrm{x}$ ] e usar a função 'buscar e substituir' para trocar todas as referências ao [tema x] por referências ao [tema y]. [Adiante abordar-se-á a questão de saber o que é que os termos 'porção significativa' e 'grave' poderão querer dizer em situações concretas].

Outros exemplos de atos considerados infração grave acontecem quando o estudante:

- altera uma obra ou um texto por forma a dar a ideia de que o estudante realizou uma quantidade de trabalho maior do que aquela que produziu na realidade - por exemplo acrescentando a um trabalho escrito uma lista bibliográfica descarregada algures, mas que de facto não consultou, e inserindo de seguida pretensas referências pelo meio do texto;

- volta a submeter um trabalho a que já foi atribuída nota;

- utiliza programas de tradução para alterar um texto, fazendo assim com que este 'escape ao radar' das ferramentas de cotejo textual;

- submete trabalho feito por um colega.

A infração académica grave é o atropelo a normas consideradas importantes num contexto de aprendizagem mas que poderão ou não ter idêntico significado fora dos muros da universidade. Por outro lado, todos estes exemplos configuram também casos de ludíbrio, uma vez que neles se busca obter benefício injusto [em termos de aprendizagem].

Não é fácil dizer com que frequência os casos de plágio configuram, simultaneamente, exempos de infração grave e/ou ludíbrio. Quem se quiser abalançar a medir os níveis de ocorrência entre os seus próprios estudantes terá de interpretar com cautela resultados do tipo ' $80 \%$ dos estudantes afirmam recorrer ao ludíbrio'. Uma resposta destas deixa por especificar o grau de frequência e os contextos em que 
os casos ocorrem, o peso relativo da porção do trabalho em causa, qual o impacto efetivo sobre o percurso académico do estudante, etc. A ausência de informação que seja fiável, comparável e relevante torna difícil responder a uma pergunta tão genérica como 'até que ponto deveremos preocupar-nos com a infração grave?', uma vez que toda a resposta será mera 'especulação baseada no ouvir dizer' (Scanlon apud Walker, 2010: 42). Passando em revista a ampla evidência disponível, Walker (2010) descarta os testemunhos autoparticipados, que considera problemáticos, improváveis e 'de validade reduzida' (p. 42). Ainda menos fiável é pedir aos estudantes que quantifiquem o grau de ocorrência. Um estudo regista que $8 \%$ dos estudantes inquiridos afirmaram que copiavam de fontes digitais sem indicar a proveniência, mas sugerindo, ao mesmo tempo, que mais de $50 \%$ dos colegas o faziam (Scanlon e Neuman apud Walker, 2010). Existe, no entanto, alguma investigação de pequena escala, no âmbito de estudos locais, capaz de nos fornecer respostas mais localizadas e também de menor escala. Walker levou a cabo um projeto de investigação de cinco anos sobre a prática efetiva dos seus estudantes com respeito à cópia sem referenciação bibliográfica. Utilizando programas de cotejo textual, este autor dividiu os trabalhos escritos em 'plágio moderado' (menos de 20\% de texto copiado sem atribuição da autoria) e 'plágio extenso' (casos de $20 \%$ ou mais do trabalho a ser objeto de cópia não sinalizada). Walker situa em pouco mais de um quarto (26\%) o número de trabalhos escritos considerados cópia moderada ou extensa, embora não concretize até que ponto vai essa extensão. Ainda no âmbito do mesmo estudo, este autor concluiu que, em 566 trabalhos entregues, 5 eram, 'em grande parte ou na totalidade, obra de outro estudante', e que 'numa outra tarefa dada ao mesmo grupo de estudantes, foram 6 em 532 os casos de "apropriação" registados'. Walker, que não detetou casos de trabalhos encomendados, observa ainda que não se pode generalizar a partir destes resultados, apurados na Nova Zelândia a partir de uma coorte de estudantes (um misto de nacionais e estrangeiros) de uma licenciatura em economia e gestão. 
Estudos há, também, de maior escala. Nos EUA, Donald McCabe tem levado a efeito inquéritos envolvendo centenas de milhar de estudantes, com base em relatos de auto-observação das práticas de cópia e outras formas de utilização de texto digital sem referenciação. Segundo McCabe, em 1999, 13\% dos estudantes afirmaram copiar com regularidade (sem, contudo, especificar que porção dos trabalhos apresentados tinha essa origem), sendo a percentagem de $41 \%$ em 2001. Tais resultados revelam a subida acentuada do índice de ocorrência a partir do momento em que os recursos da Internet passaram a estar mais disponíveis. No entanto, o estudo nada diz sobre a extensão ou volume da cópia (McCabe, 2003). Num estudo realizado em 2005, McCabe pediu a estudantes que indicassem quatro comportamentos considerados 'batota' ou ludíbrio grave. A lista daí resultante dá nota das respostas de estudantes de licenciatura (Lic) e de pós-graduação (PG) que revelaram ter tido estes comportamentos no ano anterior:

- 'apresentação de trabalho da autoria de outrem' - 8\% Lic / 4\% PG;

- 'cópia de grandes porções de texto escrito sem indicação da fonte' - 7\% Lic / 4\% PG;

- 'apresentação de trabalho feito por outro [estudante]' - 7\% Lic / 3\% PG;

- 'obtenção de trabalho através de uma "fábrica de ensaios para exames»' - 3\% Lic / 2\% PG.

McCabe acrescenta que 'é talvez de presumir que o nível efetivo seja mais elevado do que mostram estes resultados' (McCabe, 2005).

Na minha universidade, no Reino Unido, o conjunto das infrações aos regulamentos académicos foi classificado de acordo com três níveis, o mais gravoso dos quais recebeu a designação de falta ou 
infração grave ${ }^{12}$. Aqui, os registos coligidos ao cabo de mais de uma década mostram que as situações de infração grave se situaram, habitualmente, entre $10 \%$ e $20 \%$ do número total de casos. Desses casos, por sua vez, foi diminuto o número dos que envolveram fraude e/ou infração às normas punível com aplicação de multa, expulsão, ou recusa da outorga de habilitação profissional. Com efeito, esse número raramente atingiu os dois dígitos, entre mais de 20.000 estudantes matriculados (ver Carroll e Appleton, 2005; Carroll, 2005). Por outro lado, não há maneira de saber até que ponto estes resultados representam uma subavaliação do número de casos realmente verificados.

Voltando à questão da frequência e do nível de gravidade das infrações de natureza académica, proponho que a melhor forma de solucionar o dilema é partir do princípio de que a infração grave ocorre num número de casos significativo - suficientemente significativo para se pressupor que se trata do método preferencial de alguns estudantes na maior parte das coortes. Sempre que se verificam índices de infração baixos ou muito baixos, o mais certo é haver omissão de casos ou estes estarem a passar despercebidos. Por fim, independentemente do nível, as indicações de que dispomos já são de molde a justificar que se invistam recursos e esforços na gestão da totalidade dos casos, mas não a justificar a crença de que todos os casos configuram infração grave nem que devamos criar sistemas especificamente vocacionados para a deteção e gestão desse nível de infração. É minha experiência que a criação de sistemas primacialmente orientados para a gestão do ludíbrio leva a que os processos se tornem sobrejuridificados e burocratizados; a que as relações azedem, devido à atitude defensiva e ao ambiente de suspeição; e a que sejam adotadas medidas que ameaçam a totalidade dos estudantes

12 A divisão da classificação em três níveis é comum a muitos sistemas de gestão. Veja-se, por exemplo, Yeo e Chen (2007) e a sua descrição do procedimento em vigor na Curtin University, na Austrália, onde é utilizada uma ficha de uma só página. 
no processo de aprendizagem - tudo isso quando a verdade é que nada indica que exista melhor forma de gestão dos casos do que uma abordagem de tipo construtivo e centrada na aprendizagem. Para visões consonantes com esta, veja-se, por exemplo, Sutherland-Smith (2010); Blum (2007); Devlin (2006).

\subsubsection{Distinção entre ludíbrio e fraude}

O estudante que comete fraude é levado pelo desígnio de enganar. E quando o faz, ele está, em alguns casos, a infringir não só as normas próprias do meio universitário, como também as leis reconhecidas fora desse meio. Nos exemplos de comportamento fraudulento incluem-se a falsificação de dados, o roubo, a obtenção de dados através de ameaça ou intimidação, o fazer-se passar por outrem e/ou pagar a outrem para produzir trabalho que depois é apresentado como sendo de quem o apresenta, tudo isso para obtenção de créditos ou outro benefício próprio. Este último exemplo, frequentemente designado por encomenda e, por vezes, ludíbrio contratado (Lancaster e Clark, 2007), é também muitas vezes gerido em função das normas criadas para a gestão do plágio. A prática de lidar com o trabalho encomendado como se de plágio se tratasse deve-se, muito provavelmente, à circunstância de os produtos encomendados serem submetidos dentro do contexto letivo, assemelhando-se por isso aos trabalhos gerados pelas modalidades de infração académica grave em que se inclui o plágio. A verdade, no entanto, é que o trabalho encomendado sai, em rigor, fora do quadro das políticas de gestão do plágio. Assim, nestas deverão estar previstas maneiras de separar liminarmente os casos de encomenda, que haverá então que tratar como qualquer outra prática fraudulenta. Adiante avançam-se mais recomendações acerca da gestão da fraude.

Concluindo, uma política e um conjunto de procedimentos eficazes com vista à gestão do plágio estudantil passam, obrigatoriamente, 
por um entendimento comum e devidamente fundamentado daquilo que são as diferenças entre plágio, ludíbrio e fraude. As políticas a concretizar deverão estabelecer de maneira explícita a correlação entre, por um lado, os valores relativos à aprendizagem estudantil e, por outro, os requisitos pedagógicos respeitantes à utilização e sinalização do trabalho alheio. Elas deverão, assim, explicitar devidamente o modo como os estudantes têm de fazer prova da sua aprendizagem, bem como o modo como devem sinalizar o trabalho alheio. Há que ter o cuidado de evitar dar a ideia de que as convenções da referenciação bibliográfica são universalmente reconhecidas como uma evidência de integridade. Pelo contrário, as convenções e requisitos do foro pedagógico andam intimamente ligados àquilo que é o comportamento considerado importante num meio universitário/ de investigação específico. Já no caso do ludíbrio e da fraude, porém, são convocados os valores universais da justiça, da honestidade e da transparência.

Passo, de seguida, a ocupar-me daquilo que serão as caraterísticas de uma política institucional e os procedimentos para uma gestão justa, coerente, defensável e eficiente do plágio estudantil.

\subsection{Guia de boas práticas das políticas e procedimentos a seguir na gestão do plágio estudantil}

Para efeitos do presente capítulo, os exemplos de diretrizes e de boas práticas apontados restringem-se a autores e projetos sediados em universidades de língua inglesa. Seguramente existem outros exemplos para além da bibliografia com que estou mais familiarizada. Da lista de bibliografia fornecida no final constam as referências completas das fontes a que tive acesso. Entre as fontes anglófonas especialmente úteis para o estudo de boas práticas, contam-se as seguintes: 
- Policy Works.

Relatório publicado em 2011 pela Higher Education Academy ${ }^{13}$ do Reino Unido. Propõe um elenco de 12 aspetos para uma abordagem eficaz da gestão do plágio;

http://www.heacademy.ac.uk/assets/documents/academicintegrity/policy_works.pdf

- Bretag et al. (2011), 'Core elements of exemplary academic integrity policy in Australian higher education'.

Artigo australiano assinado por nove autores, em que se resumem os resultados de um estudo de três anos, financiado pelo Estado, sobre políticas e procedimentos destinados a estimular e apoiar a integridade académica. Os resultados baseiam-se nas respostas de mais de 15.000 estudantes a um questionário sobre as respetivas atitudes e crenças;

- Sutherland-Smith (2010), 'Retribution, deterrence and reform: the dilemmas of plagiarism'.

Artigo de uma professora universitária australiana com formação em direito, em que esta analisa o impacto que a linguagem jurídica e as metáforas da esfera do crime têm sobre a conceção e execução das estratégias para a gestão do plágio. A autora faz uma descrição das reações a situações de perceção de pânico moral, afastando qualquer receio de que o plágio seja algo de incontrolável.

- 'Defining and Avoiding Plagiarism: The WPA Statement on Best Practices'.

Documento disponibilizado no sítio eletrónico do Conselho dos Writing Program Administrators ${ }^{14}$ - WPA (2003), sediado nos EUA. Na descrição que dele é dada, lê-se que

'Academia do Ensino Superior'. [N.T.]

14 Administradores de Programas de Composição Escrita. [N.T.] 
procura 'dar resposta, em quatro vertentes, às crescentes preocupações com o plágio: definindo o que é o plágio; apontando algumas das causas do plágio; propondo um conjunto de responsabilidades (tanto de discentes como de docentes e responsáveis administrativos) para fazer frente ao problema do plágio; e recomendando um conjunto de práticas de ensino e aprendizagem passíveis de reduzir significativamente a probabilidade de ocorrência do plágio';

http://wpacouncil.org/positions/WPAo plágio.pdf.

- (Carroll, 2007) 'The Handbook for Deterring Plagiarism in Higher Education'

Nesta obra detenho-me sobre medidas e procedimentos, entendidos como parte integrante de uma abordagem holística ou concertada do problema da gestão do plágio.

Muitas universidades desenvolveram políticas que posteriormente foram revendo à luz da experiência, publicando, nalguns casos, os resultados obtidos. Veja-se, por exemplo, Park (2004) e Macdonald e Carroll (2006), no Reino Unido; Devlin (2006), Yeo e Chein (2007) e Martin e Haeringen (2011), na Austrália; de Lambert, Ellen e Taylor (2006), na Nova Zelândia.

\subsection{Caraterísticas de uma política eficaz de gestão do plágio}

\subsubsection{A gestão do plágio requer uma abordagem de tipo bolístico}

As ações a empreender, bem como as responsabilidades, devem ser partilhadas por estudantes, professores, e pela universidade no seu todo. A gestão do plágio estudantil deve, assim, procurar articular as iniciativas de maneira a: 
- passar para os estudantes a informação pertinente.

As políticas e procedimentos deverão dizer explicitamente de que modo os estudantes devem tomar conhecimento dos regulamentos e requisitos pedagógicos respeitantes à utilização e sinalização do trabalho alheio, não se ficando, assim, pela mera mecânica e pelas convenções de formatação de um dado sistema de referenciação bibliográfica;

- fomentar o desenvolvimento das competências dos estudantes. Segundo um estudo realizado na Austrália, os estudantes 'não têm falta de informação sobre a integridade académica; o que se passa é, antes, que não recorrem à vasta informação disponível' (Gullifer e Tyson apud Bretag et al., 2014: 1165). O planeamento deverá fomentar um desenvolvimento ao longo do tempo, visando uma evolução progressiva das competências neste domínio;

- assegurar que a avaliação visa promover o trabalho genuíno, desincentivando assim, por outro lado, a possibilidade de trabalho passivel de ser copiado, 'pesquisado' ou falseado.

- criar procedimentos de gestão que não prejudiquem o avaliador que deteta o plágio.

A deteção de um determinado caso não deverá 'sair cara' a quem o aponta. As modalidades de prejuízo pessoal podem traduzir-se em termos de tempo, mau relacionamento com os colegas docentes, riscos para o relacionamento com os estudantes, receio de ser contrariado ou posto em dúvida, etc. Tenho ouvido a literalmente centenas de professores, em universidades de todo o mundo, a confirmação da ideia de que, sempre que a deteção de um caso implica estas desvantagens, acabam por evitar apontá-los. McCabe (2005) refere que $41 \%$ dos professores que responderam aos seus amplos inquéritos afirmaram ignorar casos de plágio. Martin e Haerignen (2011), por seu turno, registam um aumento 
de oito vezes na comunicação de ocorrências após a introdução de um sistema em que essa comunicação passa a ser centralmente apoiada e a contar com mecanismos de participação formal claros. Outro modelo passível de poupar a figura do 'detetor' é o sistema do Academic Conduct Officer, abaixo descrito.

- apostar numa gestão coerente.

A coerência faz aumentar a probabilidade de que os procedimentos sejam vistos como justos e merecedores de confiança. Para que a coerência esteja devidamente alicerçada, as políticas adotadas deverão explicitar de que forma, por quem, e com que base em que critérios é que as decisões são tomadas. Além disso, nos procedimentos deverá estar prevista a forma como os decisores comunicam entre si, como comparam as decisões, partilham as dúvidas, etc. Os benefícios advindos da criação de toda uma comunidade em torno de uma prática constituem uma das razões pelas quais se recorre a especialistas - e não, de forma isolada, a membros do corpo docente - para emitir decisões do foro académico, porquanto é maior a probabilidade de os especialistas irem sedimentando a experiência acumulada após um número significativo de casos. Acresce que os especialistas são também de mais fácil acesso para efeito de acompanhamento e de desenvolvimento profissional (Carroll e Appleton, 2005). Tudo isto são fatores que reforçam a coerência;

- manter registos.

As políticas adotadas devem dizer explicitamente que dados devem ser guardados, de que forma e por quem;

- tornar clara a articulação com os procedimentos relativos à garantia da qualidade.

A articulação com a qualidade codifica as responsabilidades pela gestão do plágio estudantil ao mesmo tempo que 
mantém os problemas na agenda das instituições e reforça a probabilidade de aumento dos recursos a afetar.

\subsection{A gestão do plágio requer que as decisões do foro pedagógico pertençam aos docentes}

Há países em que as decisões respeitantes ao plágio cabem ao corpo docente; noutros, elas ficam fora da alçada das medidas normais em vigor no âmbito da qualidade pedagógica. Quando é esta última situação que vigora, a gestão das ocorrências torna-se bastante problemática.

O trabalho desenvolvido por Glendinning e colegas (2013) no âmbito de um estudo sobre a gestão do plágio realizado em toda a União Europeia concluiu que em muitos países se exige que o processo de decisão seja partilhado entre responsáveis académicos e outras entidades, como advogados, provedores, e defensores da causa dos estudantes. Sempre que o processo de decisão sofre alteração, tal significa, por norma, a passagem de uma ênfase na aprendizagem para uma ênfase nas responsabilidades e nos direitos legais (Carroll e Zetterling, 2009). Entre as consequências de uma eventual passagem para procedimentos de pendor legalista e com níveis de prova contam-se as seguintes:

- maior demora dos processos.

Em lugares em que trabalhei e onde a responsabilidade estava cometida a Academic Conduct Officers, por exemplo, os casos eram tratados no prazo de uma ou duas semanas; na universidade sueca em que também servi e onde a gestão das ocorrências não se encontrava sob o controlo dos docentes, a duração média de cada processo era de 11 meses;

- aumento da exigência em matéria de prova, geralmente indo muito para além do que seria um juízo com base na ponderação das probabilidades. O critério da ponderação das 
probabilidades constitui o nível normal no âmbito do direito civil, porém aqui assiste-se à introdução de um requisito de prova 'para além da dúvida', o que é completamente descabido em contexto pedagógico (Sutherland-Smith, 2010);

- aumento dos níveis de confrontação.

Sucede muitas vezes tornarem-se comuns os interrogatórios e inquirições a docentes - colocando-os na defensiva -, a contestação das decisões do foro pedagógico, etc. A título de exemplo refira-se que, antes da criação dos ACOs e da fixação de níveis de prova necessária para a produção da respetiva decisão, a documentação de uma ocorrência numa universidade do Reino Unido obrigava, em média, a 12 dias de trabalho. Após a reestruturação dos sistemas no sentido de garantir que os juízos tivessem fundamento em determinados critérios e fossem cometidos a especialistas do gabinete do ACO, o processo de averiguação e confirmação de cada caso passou a poder ser concluído, em regra, no espaço da reunião/entrevista de uma hora ou, nos casos complicados, em algumas horas apenas. Em contraste com esta situação, na Suécia os casos eram discutidos na presença de advogados e de um juiz aposentado e implicavam resmas de documentos, por vezes com mais de $10 \mathrm{cms}$;

- redução do número de processos geridos.

Não obstante a minha universidade inglesa e a minha universidade sueca terem, aproximadamente, a mesma dimensão e serem frequentadas por estudantes com perfil idêntico, os casos identificados no Reino Unido em que o plágio foi expressamente gerido e registado ascenderam a muitas centenas por ano, ao passo que na universidade sueca não passaram de poucas dezenas, havendo mesmo um ano sem qualquer ocorrência;

- inflexibilidade das decisões.

A manutenção dos processos na esfera propriamente académico-pedagógica permite a utilização de tabelas de 
penalização (abaixo descritas), que poderão variar de maneira a refletir os níveis de gravidade. Quando a gestão é feita fora desse contexto, as penalizações tendem a ser em número reduzido, não deixando, por vezes, ir além da suspensão por um período determinado. Esta circunstância pode levar a que tanto professores como estudantes sintam que as penalizações são injustas e/ou desproporcionadas.

\subsection{A gestão do plágio requer uma utilização hábil das estratégias de deteção}

Os docentes e, em geral, os corretores ou avaliadores de testes deverão lançar mão de um vasto leque de mecanismos para identificar material não original apresentado pelos estudantes. Walker (2010) observa que a competência na deteção '... tem a ver com experiência, perspicácia, domínio dos conteúdos, um bom conhecimento da turma, e bom senso' (p. 43). Constituirá má prática identificar o plágio, seja de tipo eletrónico ou outro, com base em apenas uma destas condições, tal como não será realista supor que os professores possuem, à partida, a perspicácia e as competências necessárias a um uso eficaz da metodologia usada, qualquer que ela seja (Badge, Cann e Scott, 2007). As políticas a adotar terão de acautelar a forma de prover as necessidades de desenvolvimento profissional dos professores enquanto agentes de deteção do plágio.

\subsubsection{A gestão dos casos detetados tem de ser eficiente}

Nas instituições em que os casos de plágio são geridos de maneira eficaz, a sua ocorrência é relativamente elevada. Quando o número é pequeno, é muito provável que tal se deva mais a uma 
gestão deficiente do que a um índice baixo de frequência. Daí dever concluir-se que há que conceber procedimentos no sentido de tratar os casos de plágio como um aspeto normal e de dimensão considerável da vida académica. Para serem eficientes, os procedimentos têm de ser sustentáveis e dotados dos recursos adequados, inclusivamente assegurando que as exigências em matéria de prazos têm correspondência no planeamento da carga de trabalho a distribuir e na nomeação de quem irá ser chamado a investir o seu tempo na gestão dos processos.

\subsubsection{Os procedimentos de gestão dos processos têm de ser justos, coerentes e defensáveis}

A coerência é passível de ser posta em risco em qualquer momento da abordagem holística. Assim, a incoerência poderá residir no próprio ensino ministrado, nas oportunidades de exercitar as competências, na irregularidade do contacto com formas de avaliação bem concebidas, na inconstância da disponibilidade ou abertura para a identificação de casos, etc. E no entanto parece existir, da parte tanto de estudantes como de professores, uma particular preocupação no sentido de que haja coerência nas penalizações e na sua aplicação. Com este fim em vista, Tennant e Duggan (2008) e Tennant e Rowell (2009-10) publicaram relatórios no âmbito do projeto AmBer em que se indagava que penalizações eram utilizadas, e com que frequência, nas universidades do Reino Unido, e ainda quais as penalizações preferenciais. Carroll e Appleton (2005) descrevem a utilização de uma tabela de penalizações destinada a garantir a coerência das decisões.

O requisito da defensabilidade obriga a que a informação relativa ao modo como as decisões são tomadas e ao respetivo fundamento seja explícita e transparente. 


\subsubsection{A gestão do plágio estudantil requer um arquivo de re- gistos de qualidade}

A manutenção de registos, e sobretudo a respetiva verificação e avaliação, permitem que tanto as pessoas individualmente como as instituições possam aprender com a gestão que fazem do plágio estudantil e aperfeiçoá-la. Com efeito, o registo de casos poderá levar segmentos da universidade em que não tenha sido evidenciada qualquer atividade neste âmbito a enveredar por medidas eficazes e de tipo holístico.

3.6.4. A gestão do plágio deve enquadrar-se nos procedimentos de gestão da qualidade (GQ) em vigor na universidade

Tanto os dados como as questões de gestão propriamente dita resultantes da deteção e gestão do plágio deverão articular-se com os procedimentos de gestão da qualidade seguidos na instituição. A participação formal poderá ser feita junto de comissões específicas, de pessoas, ou de estruturas de governo interno.

\subsection{A adoção de uma abordagem holística: por onde começar?}

Ao fim de mais de uma década a trabalhar com centenas de universidades no desenvolvimento e montagem de políticas para lidar com o plágio, aprendi que é possível começar em qualquer ponto da lista holística de atividades acima referida. Algumas universidades começam pela informação aos estudantes, outras começam por reelaborar as políticas em vigor, outras por rever os métodos de avaliação, e outras ainda começam por incentivar a deteção de casos e dotá-la de recursos, normalmente através da introdução de 
software de cotejo textual. A maioria das universidades parece evoluir posteriormente para outras questões constantes da lista e por vezes acaba por aplicá-las na totalidade, completando assim a abordagem holística. Geralmente esse processo leva anos.

Não obstante as universidades poderem começar em qualquer ponto, há um elemento da abordagem holística que parece especialmente apto a desbloquear a letargia e resistência institucionais. Esse elemento é a garantia, para quem deteta um caso, de que não irá, por isso, sofrer prejuízo pessoal significativo. A partir do momento em que deixam de se sentir ameaçados, pressionados, inseguros e pouco à vontade com o facto de terem de lidar com casos de plágio, os professores ficam muito mais disponíveis para se envolverem com as medidas e os procedimentos relacionados com a sua gestão. A partir do momento em que veem que o sistema é flexível sem deixar de ser capaz de gerar penalizações coerentes e adequadas, começam a confiar nele e, consequentemente, a utilizá-lo. A partir do momento em que discentes e docentes veem que os resultados são justos, é habitual assistir-se a uma subida do número de participações formais de ocorrências de todo o tipo, e com o passar do tempo fica provado que a boa gestão gera um efeito positivo no comportamento dos estudantes. O número de casos acaba, assim, por baixar (Walker, 2010; Martin e Haeringen, 2011).

Um dos mecanismos para atingir resultados positivos consiste em criar um sistema em que um pequeno número de especialistas - os 'Academic Conduct Officers' - faz a gestão dos casos de plágio, de infração grave e de ludíbrio; do cargo faz parte também a atribuição de penalizações. De acordo com este sistema, os casos de fraude têm de ser remetidos pelos ACOs para comissões disciplinares da universidade. De seguida descreve-se o modo como o sistema ACO está concebido e como, ao cabo de mais uma década de experiência, ele deu provas de resultar na prática. 


\subsection{Linhas gerais do sistema do Academic Conduct Officer}

Dito resumidamente, o sistema ACO fixa o modo como aquele ou aquela que avalia um trabalho escrito deve identificar os casos de plágio e passá-los para as mãos dos especialistas. Os ACOs averiguam os casos, confirmando-os ou indeferindo-os, atribuem a penalização respetiva, registam a decisão tomada, e asseguram que o trabalho do estudante reentra no processo de avaliação normal, de maneira a que a penalização possa ser aplicada. A presente descrição contempla apenas alguns elementos de todo este quadro. Para uma descrição mais completa, ver Carroll (2007).

O primeiro passo cabe a cada professor e consiste em decidir se um determinado caso necessita de ser remetido ao ACO ao verificar-se que reúne todos os critérios da definição acima referida (Fishman, 2009). Se tal não suceder mas se o trabalho continuar a ser insatisfatório, ele poderá ser gerido através do processo normal de avaliação. Assim, e por exemplo, se o estudante usou de forma deficiente as convenções da referenciação bibliográfica mas indicou a fonte de uma maneira informal, o respetivo avaliador poderá tratar pessoalmente do problema. E quando a parte não genuína constitui uma porção diminuta do trabalho (algumas frases apenas, por exemplo, ou 5\% do todo, em passos não fundamentais), aí o plágio não interfere na capacidade do avaliador para julgar o trabalho pelos conhecimentos nele demonstrados, e o caso pode ser gerido pelo professor. A coerência passa muito pelo treino dos professores/avaliadores de modo a saberem fazer estas distinções.

Os ACOs são nomeados pela respetiva escola ou departamento para tratarem de ocorrências 'locais'. O seu âmbito de ação é variável, podendo, nalguns casos, abranger a totalidade da instituição. Há situações em que o cargo é assumido por funcionários administrativos mais antigos, mas por norma o responsável pelo departamento ou o Diretor nomeia um dos docentes com maior antiguidade (ou vários, 
como sucede nas unidades de maior dimensão e com um grande número de estudantes). O ACO deve ser visto como alguém que está próximo das exigências e preocupações da disciplina e para elas sensibilizado, deve ter a confiança dos colegas, e não lhe devem faltar os recursos que o cargo requer. Precisa de tempo, de oportunidades de desenvolvimento profissional, e de perspetivas quanto a reconhecimento profissional e promoção. A minha universidade acabou por optar pela atribuição, ao ACO, de 2.5 horas vezes o número de casos detetados no ano anterior na unidade de responsabilidade em causa (escola, departamento, secção, etc.). Sendo o número de casos muito variável quanto ao local da ocorrência, o número de ACOs por unidade foi também muito variado. O objetivo foi garantir que as cargas do trabalho distribuído se mantivessem dentro de limites geríveis, bem como assegurar um nível de capacidade suficiente para dar resposta a picos de procura nas épocas de avaliação.

Ao receber um processo, o ACO fica com a responsabilidade da respetiva averiguação (umas vezes conjuntamente com outros, de outras vezes sozinho) e de comunicar com o estudante. Não cabe no presente resumo falar das complexidades da averiguação e dessa comunicação, no entanto há que referir que o modo como devem decorrer e como lidar com o estudante não depende do ACO, mas é sim devidamente especificado e monitorizado, obrigando ao envio e devolução, dentro de prazos predeterminados, de documentos-modelo. Os prazos para reuniões e divulgação de resultados são importantes.

Em cada processo há, obrigatoriamente, lugar a uma reunião/ entrevista com a presença do estudante, do ACO e, eventualmente, de terceiros; as reuniões duram, geralmente, cerca de uma hora. O estudante poderá fazer-se acompanhar de alguém, cujo papel de apoio, no entanto, está previsto que seja bastante limitado. O ACO inicia a reunião tentando indagar se existe fundamento para se concluir que houve infração dos regulamentos académicos e, sendo essa a 
situação, qual o nível de gravidade. Haverá um momento (geralmente cerca de 20 minutos após o início da reunião) em que o ACO decide, ou avançar, por considerar que efetivamente houve uma infração, ou devolver o processo ao docente para nova correção, já no quadro dos critérios normais da avaliação. Nessa altura a reunião é interrompida e é dado ao estudante um breve período de tempo para pensar e decidir se pretende que a reunião prossiga de imediato ou em data posterior. Caso a reunião continue de seguida, o ACO toma a sua decisão quanto ao nível de gravidade. Ao ajuizar sobre o nível de gravidade, os ACOs deverão ponderar os seguintes critérios:

- a porção do trabalho que não é da autoria do aluno.

- a importância relativa dessa parte no conjunto do trabalho. Um ACO poderá assim, por exemplo, ver se o material não genuíno se encontra num apêndice ou no corpo do trabalho; se algum desse material não genuíno chega a comprometer a autenticidade e integridade de determinado aspeto do trabalho - se, por exemplo, torna inválida a argumentação; se essa componente não genuína surge em pontos do texto em que seja tão importante a utilização de material original; etc.;

- o estádio em que o estudante se encontra no seu percurso académico.

Há que ter cautelas especiais nos primeiros tempos/meses após a matrícula. Idênticas cautelas se tornam necessárias quando se tem de levar em conta o estádio da evolução de estudantes que hajam chegado no âmbito de programas complementares ou que tenham ingressado em pós-graduações vindos de instituições com práticas e convenções pedagógicas muito diferentes;

- a circunstância de ter ou não sido concedido ao estudante suficiente ensejo para entender e aplicar as normas relativas à utilização das fontes. 
Provas de que houve 'suficiente ensejo' poderão ser a frequência de um curso de competências de estudo; a presença comprovada numa sessão de orientação oferecida pelo departamento, com posterior acompanhamento - devidamente documentado - em trabalhos entretanto apresentados; demonstração de utilização correta no resto do trabalho escrito em apreço, etc. O juízo sobre se o estudante dispôs ou não de suficiente ensejo para compreender e desenvolver as competências adequadas serve, habitualmente, de suporte indireto para as decisões respeitantes à presença de intenção. Trata-se, em ambos os casos, de juízos de natureza académica, mas na prática afigura-se mais fácil ajuizar sobre níveis de compreensão do que sobre as motivações e intentos do aluno;

- a eventual existência de provas de ludíbrio, entendido como a tentativa deliberada de enganar ou de colher benefício de forma injusta.

O ludíbrio é tratado como uma agravante da infração grave.

A utilização destes critérios tornou-se relativamente simples depois de aplicados em uma dúzia de casos aproximadamente. Não tardou, assim, que os ACOs se movessem à vontade no interior de um sistema que se revelaria suficientemente flexível para lidar com casos extremamente diferentes entre si, se bem que sujeito a um apertado leque de opções (quer dizer, a uma escolha entre não mais que três níveis de gravidade). Perante casos cuja gravidade se lhe afigurasse merecedora de penalização superior ao previsto pelo sistema, o ACO reencaminhava-os para outra instância, a Comissão Disciplinar da Universidade. Tal reencaminhamento foi o resultado habitualmente verificado nos casos de fraude (incluindo os de trabalhos encomendados), de infração grave recorrente, e de infração grave em trabalhos de valor e estatuto elevados, como teses de doutoramento ou 
trabalhos de investigação publicados. Os ACOs procederam, ainda, ao reencaminhamento dos estudantes que recorreram a métodos de fuga deliberada à deteção, como seja a retroversão ${ }^{15}$.

Voltando aos procedimentos do sistema ACO, assim que o nível (baixo, médio ou elevado) era fixado, o ACO recorria a uma tabela de penalizações em que cada nível surgia associado a determinadas consequências. Com o tempo, o número ótimo de penalizações disponíveis pareceu estabilizar em cinco ou seis e apontar para uma ou duas por nível, com algum grau de sobreposição, o que significa que a mesma penalização podia ser aplicada a níveis de gravidade diferentes. Para ajudar os ACOs a utilizar a tabela de maneira coerente, o acesso ao cargo passava por um processo de formação e de observação dos colegas, pela resolução de casos hipotéticos e pela participação num painel de discussão à porta fechada em que lhes era permitido partilhar questões e trocar pontos de vista a propósito de casos particularmente exigentes. A realização regular de reuniões - pelo menos uma por período letivo - e de conversas do âmbito profissional com especialistas do meio universitário contribuiu, ainda, para a construção de uma abordagem partilhada. Nos casos em que os ACOs funcionaram isoladamente, o fator coerência ressentiu-se (Carroll e Seymour, 2006).

Como passo seguinte, o ACO informa o estudante do resultado, fazendo-lhe o elenco das penalizações e de eventuais novas exigências em matéria de orientação ou de apoio tutorial. Além disso, deverá responder e dar solução a qualquer questão imediata e garantir que o estudante sabe onde e de que forma poderá apresentar recurso. Nesta altura o ACO procede ao registo das decisões, utiliza os procedimentos pertinentes para as comunicar a terceiros - seja o professor que fez

\footnotetext{
15 'Retroversão' designa a prática que consiste em selecionar material para uso indevido, vertê-lo para outra língua por meio de um programa como o Google Tradutor, e voltar depois a vertê-lo para a língua original. A ideia é que o texto daí resultante terá sofrido modificação suficiente para poder 'escapar ao radar' do software de cotejo textual.
} 
a participação inicial ou um painel de examinadores, por exemplo -, e remete o caso para o processo de avaliação normal. Tem então lugar, finalmente, a aplicação das consequências previstas.

Os relatórios anuais elaborados por cada um dos ACOs são fundidos num único documento respeitante a toda a universidade, que passa seguidamente para uma comissão de gestão da qualidade para efeito de análise e avaliação.

\subsection{Conclusão}

Não obstante a sua procupação com o modo de lidar com o plágio estudantil e o ludíbrio, os responsáveis pela definição das políticas e pela direção das instituições nem sempre sabem bem onde começar; alguns nem sequer se mostram dispostos a dar esse passo. Cria-se, assim, uma situação em que os professores se sentem inseguros e desapoiados e em que os estudantes se sentem vítimas injustiçadas por lhes ser imputada a responsabilidade de agir com integridade sem que lhes tenham sido fornecidos os instrumentos e o saber necessários, ao que acresce uma injustificada atribuição de culpa pela prática do ludíbrio ou por a tolerarem a outros. Sutherland-Smith (2010) apela a uma menor "ênfase sistémica na dissuasão e na penalização, [visto que] estas abordagens, só por si, têm um valor educativo questionável. A investigação académica disponível sugere que o plágio é feito de múltiplas camadas e requer toda uma variedade de estratégias dentro de um quadro global de sustentabilidade ética" (p. 13).

O presente texto vai ao encontro desta perspetiva, na medida em que propõe uma ênfase sistemática. Ou seja, ele coloca a tónica numa gestão do plágio estudantil que se deseja centrada na aprendizagem partilhada. Esta é uma causa pela qual vale a pena pugnar em nome dos nossos estudantes e que vale a pena defender com vista à preservação dos valores do estudo universitário e dos graus que ele confere. 


\subsection{Referências bibliográficas}

Ashworth P.; Freewood, M. e Macdonald, R. (2003). The student lifeworld and the meanings of plagiarism. Journal of Phenomenological Psychology, 34(2), pp. 257-278.

Badge, J.; Cann, J. e Scott, J. (2007), To cheat or not to cheat? A trial of the JISC plagiarism detection service with biological science students. Assessment and Evaluation in Higher Education, 32(4), pp. 1-7.

Blum, S. (2007), My Word! Plagiarism and College Culture. Ithaca, NY - USA: Cornell University Press.

Bretag, T.; Mahmud, S.; Wallace, M.; Walker, R.; Green, M.; East, J.; James, C.; McGowan, U. e Partridge, L. (2011), Core elements of exemplary academic integrity policy in Australian higher education. International Journal for Educational Integrity, $7(2)$, pp. 3-12.

Bretag, T.; Mahmud, S.; Wallace, M.; Walker, R.; McGowan, U.; East, J.; Green, M.; Partridge, L. e James, C. (2014), Teach us how to do it properly! An Australian academic integrity student survey. Studies in Higher Education, 39(7), pp. 1150-1169.

Carroll, J. (2005), Handling student plagiarism: moving to mainstream. Brookes eJournal of Learning and Teaching, 2(2).

Carroll, J. (2007), A Handbook for Deterring Plagiarism in Higher Education. Oxford Centre for Staff and Learning Development. Oxford, UK: Oxford Brookes University.

Carroll, J. (no prelo), Tools for Teaching in an Educationally Mobile World. Londres e Nova Iorque: Routledge.

Carroll, J. e Appleton, J. (2005), Towards consistent penalty decisions for breaches of academic regulations in one UK university. The International Journal for Educational Integrity, 1(1).

Carroll, J. e Seymour, D. (2006), The effect of a penalty tariff on consistent decision-making in cases of student plagiarism. Proceedings of the JISC International Plagiarism Conference. Obtido em http://www.jiscpas.ac.uk/2006papers.php Carroll, J. e Zetterling, C-M. (2009), Guiding Students away from Plagiarism / Hjälp studenterna att undvika plagiering, Learning Lab. Stockholm, Sweden: Royal Technical University. 
Davis, M. (2013), The development of source use by international postgraduate students. The Journal of English for Academic Purposes, 12, pp. 125-135.

de Lambert, K. ; Ellen, N. e Taylor, L. (2006), Chalkface challenges: a study of academic dishonesty amongst students in New Zealand tertiary institutions. Assessment and Evaluation in Higher Education, 31(5), pp. 485-503.

Deech, R. (2006), Plagiarism and institutional risk management, Conference for PlagiarismAdvice.org. Obtido em http://plagiarismadvice.org/research-papers/ item/plagiarism-and-institutional-risk-management

Devlin, M. (2006), Policy, preparation, and prevention: Proactive minimization of student plagiarism. Journal of Higher Education Policy and Management, 28, pp. $45-58$.

Fishman, T. (2009), "We know it when we see it" is not good enough: toward a standard definition of plagiarism that transcends theft, fraud, and copyright. $4^{\text {th }}$ Asia Pacific Conference on Educational Integrity (4APCEI) 28-30, setembro, University of Wollongong NSW Australia.

Glendinning, I. (2013), Impact of policies for plagiarism in Higher education across Europe - project results. Obtido em 3 de maio de 2014 em http://ippheae.eu/ project-results.

Gu, Q.; Schweisfurth. M. e Day. C. (2010), Learning and growing in a 'foreign' context: intercultural experiences of international students. Compare, 40(1), pp. 7-23.

Howard, R. (2008), Plagiarizing (from) graduate students. R. M. Howard e A. E. Robillard (Orgs.), Pluralizing plagiarism: Identities, contexts, pedagogies (pp. 92-100). Portsmouth, NH: Boynton/Cook.

Hunt, R. (2004), Whose silverware is this? Promoting plagiarism through pedagogy. JISC Plagiarism Advisory Service Conference, Newcastle-upon-Tyne, UK, 24-28, junho.

Lancaster, T. e Clarke, R. (2007), The phenomena of contract cheating. In T.S Roberts (Org.), Student plagiarism in an online world: Problems and solutions (pp. 144-158). Hershey, PA: Idea Group Inc.

Macdonald, R. e Carroll, J. (2006), Plagiarism - a complex issue requiring a holistic institutional approach. Assessment and Evaluation in Higher Education, 31(2), $233-245$. 
Martin, J. e Haeringen, K. (2011), Can a policy change practice? An evidence-based approach to developing policy. The International Journal for Educational Integrity, 7(2), pp. 13-22.

McCabe, D. (2003), Promoting academic integrity: a US/Canadian perspective. Educational Integrity: plagiarism and other perplexities. First Australasian Educational Integrity conference, 21-22 de novembro, Adelaide, S. Australia. McCabe, D. (2005), Cheating among college and university students: a North American perspective. International Journal for Educational Integrity, 1(1), pp. 1-11.

McGowan, U. (2005), Does educational integrity mean teaching students NOT to 'use their own words'? International Journal for Educational Integrity 1(1).

Neville, C. (2009), International Students, writing and referencing. Referencing and writing symposium. University of Bradford, UK, 9 de junho.

Park, C. (2004), Rebels without a clause: towards an institutional framework for dealing with plagiarism by students. Journal of Further and Higher Education, 28(3), pp. 291-306.

Partridge, L. e West, J. (2003), Plagiarism: perceptions and occurrence amongst transnational students in the Graduate School of Education, University of Western Australia. Educational Integrity: plagiarism and other perplexities, proceedings of the first Australasian Educational Integrity conference, Adelaide, Australia, 21-22, novembro, pp. 149-153.

Sutherland-Smith, W. (2010), Retribution, deterrence and reform: the dilemmas of plagiarism. Journal of Higher Education Policy and Management, 32(1), pp. 5-16.

Tennant, P. e Duggan, F. (2008), Academic Misconduct Benchmarking Research Project: Part 2. The Recorded Incidence of Student Plagiarism and the Penalties Applied. The Higher Education Academy and JISC. Obtido em 27 de abril de 2014 em www.heacademy.ac.uk/assets/York/documents/AMBeR_PartII_Full_Report.pdf Tennant, P. e Rowell, G. (2009-2010), Benchmark Plagiarism Tariff: A benchmark tariff for the application of penalties for student plagiarism in higher education. Relatório no âmbito do projeto AmBer. Obtido em 2 de maio de 2014 em http://www.plagiarismadvice.org/resources/institutional-approaches/item/ tennant-referencetariff 
Walker, J. (2010), Measuring plagiarism: researching what students do, not what they say they do. Studies in Higher Education, 35(1), pp. 41-50.

Whitley, B. e Keith-Spiegel, P. (2002), Academic Dishonesty: an educator's guide. Mahwah, NJ: Lawrence Erlbaum Associates.

WPA/ Council of Writing Program Administrators (2003), Defining and avoiding plagiarism: the WPA statement of best practice'. Obtido em 28 de abril de 2014 em http://wpacouncil.org/positions/WPAplagiarism.pdf.

Yeo, S. e Chien, R. (2007), Evaluation of a process and proforma for making consistent decisions about the seriousness of plagiarism incidents. Quality in Higher Education, 13(2), 187-204. 


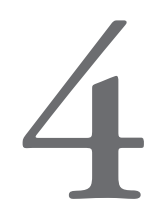

\title{
PRODUÇÃO DE MONOGRAFIAS E DE TESES:
}

A TENTAÇÃo do PLÁGIO

\author{
Michelle Bergadaà
}

Universidade de Genebra

Autora do Site "Responsable"

bttp://dx.doi.org/10.14195/978-989-26-1123-5_4 
(Página deixada propositadamente em branco.) 


\subsection{Produção de monografias e de teses}

O nosso campo de investigação diz respeito ao plágio realizado aquando da produção de trabalhos académicos, quer se trate de monografias de estudantes, de teses de doutoramento ou de artigos científicos. O que estes atos de desvio individuais revelam é a inaptidão dos nossos sistemas académicos para captar a amplitude do fenómeno, seja ao nível individual, organizacional ou societal. É por isso que todos os anos um grande número de diplomas ou teses complacentes são atribuídos com uma certa indiferença. Esta indiferença conduziu-nos a enunciar como premissa que um professor, um orientador de tese ou um júri que não garantam uma ética prática sólida, opondo-se formalmente aos comportamentos de plágio, trazem eles próprios prejuízo à nossa comunidade, às gerações de investigadores vindouros e ao saber. $\mathrm{E}$, certos casos que alimentaram recentemente a imprensa francesa fizeram disso $\mathrm{eco}^{16}$, aqueles de entre nós que, de consciência plena, contribuem para atribuir diplomas de complacência podem ser considerados como defraudadores relativamente ao nosso sistema de validação do adquirido. Não existem "pequenos prevaricadores/infratores" (i.e. prevaricadores que, por negligência, atribuem títulos de doutoramento não merecidos) e "grandes prevaricadores" (que atribuem títulos de doutoramentos com base em teses plagiadas).

Neste capítulo, ocupar-nos-emos do plágio na realização de monografias e dissertações de mestrado ou teses de doutoramento e

16 Ver o caso reportado pelo Monde Toulouse. 
não do plágio presente em certos artigos científicos. O caso dos autores de teses de doutoramento é diferente, no que diz respeito às suas razões, daquele que se refere às monografias de mestrado. No primeiro caso, todos os testemunhos que recebemos por parte dos plagiadores bem como dos seus professores, orientadores de tese e membros do júri dão a entender que o plágio nunca é senão o último recurso do doutorando confrontado com um reposicionamento da sua própria visão no que diz respeito ao seu lugar no nosso sistema e ao seu fracasso face às exigências que lhe são feitas. O sistema académico coloca fasquias elevadas a fim de poder filtrar os indivíduos que pretendem obter um título. Essas fasquias tornam-se intransponíveis para alguns doutorandos, o que se traduz na apropriação das realizações de outrem através do plágio. Pelo contrário, o modo operatório do redator que opta por um comportamento plagiador de uma monografia de mestrado ou de doutoramento é hoje semelhante e tratá-lo-emos, em seguida, integrando-o no domínio da tentação.

\subsection{A tentação do plágio no mestrado}

Mesmo antes de entrar no mestrado, o estudante que deve apresentar uma monografia de uma centena de páginas adquiriu hábitos de trabalho claramente distintos dos que eram praticados pelos estudantes do século xx. Em qualquer caso, o estudante de hoje tem sistematicamente falta de tempo para produzir esse objeto de forma paralelepipédica, incluindo, tanto quanto possível, imagens a cores, completado por uma bibliografia e apresentando uma bela encadernação, que deve entregar numa determinada data. O objetivo é sempre o de obter uma nota aceitável a fim de prosseguir da melhor forma o seu caminho; será porventura, raramente, o de adquirir alguns conhecimentos novos. O seu ato de produção vai desenrolar-se de acordo com um caminho bem rodado. 
A primeira etapa será a de analisar os termos do tema e o estudante pede informações sobre o número de páginas, o tamanho dos carateres e o número de referências bibliográficas exigidas. Dado que o professor só raramente define com clareza o seu projeto pedagógico, o aluno não se interroga por iniciativa própria sobre as virtudes de uma validação das suas aquisições mediante a realização de uma monografia relativamente a um exame clássico. Como poderia ele imaginar que o seu professor tenha escolhido deliberadamente a possibilidade de, graças a esse exercício, desenvolver qualidades cognitivas específicas?

O estudante pensará naturalmente que o seu trabalho será lido superficialmente e que o professor não se dará ao trabalho de descobrir nas entrelinhas as suas aptidões pessoais.

A segunda etapa do seu trabalho vai consistir em decompor o tema com que vai debater-se, encontrando as palavras-chave e os sinónimos para consultar (rapidamente) a Wikipedia e encontrar os textos relativos a essas palavras-chave. Raros são os professores que encontram tempo para consultar essa bíblia wikipediana a fim de verificar os conceitos relativos ao seu ensino. Encontrariam certamente grandes asneiras e poderiam debatê-las nas aulas. Mas também eles têm pouco tempo para esse trabalho suplementar. E ainda têm menos tempo para enriquecer as páginas dessa enciclopédia colaborativa com o seu saber e também não podem pedir esse contributo aos seus estudantes.

Quando o estudante já adquiriu uma visão espacial do tema, quando já conhece grosso modo as suas fronteiras, a caça ao tesouro representará uma etapa essencial do seu percurso: verificar se existe, algures, num outro país ou ali mesmo ao lado, monografias ou teses já produzidas por estudantes e disponibilizadas em livre acesso. São numerosas as universidades que colocam este tipo de documentos em linha e como tal, atendendo a que também a escolha de temas é limitada, a caça ao tesouro 
está muito facilitada. Se é certo que os professores não exercem nenhum controlo, o estudante contentar-se-á muitas vezes em descarregar integralmente uma monografia, modificando o seu nome e os agradecimentos. Se o estudante não tem qualquer interesse pela matéria ministrada pelo professor e se considerar que há uma fraca probabilidade de ser apanhado em flagrante delito de fraude poderá ainda comprar um trabalho concluído num dos sites conhecidos de "partilha de trabalhos", ou recorrer ao serviço de especialistas que oferecem os seus préstimos mediante pagamento, escrevendo a monografia completa sob encomenda. Em qualquer destes dois modelos económicos o estudante pensa estar a contribuir para um modelo colaborativo generoso. No primeiro caso, serão devidas royalties ao estudante que depositou uma monografia e a vende por intermédio desses numerosos sites que foram desabrochando na Internet. No segundo caso, permitirá a um jovem professor ou a um doutorando pouco endinheirados ganhar a vida no mercado negro. Nestes dois modelos económicos, ser-lhe-á garantido que os trabalhos não são plagiados, logo que não corre riscos.

No entanto, se o estudante se interessa pelos seus estudos evitará defraudar o sistema e construirá o seu trabalho com a ajuda da Web. Ele vai navegar livremente na rede copiando aqui e ali parágrafos que lhe servirão para preencher o seu índice temático. Isso servir-lhe-á, sem qualquer dúvida, de inspiração pois por que razão os temas tratados haveriam de ser diferentes de país para país se os professores ensinam a mesma matéria? Um percurso rápido pelas monografias disponíveis em linha permite ao estudante estruturar o seu índice. Em seguida, o estudante começará a construir o seu texto, articulando os diferentes fragmentos de texto retirados das consultas das diversas monografias consultadas. Pouco a pouco, o número de páginas colecionadas vai aumentando até ao ponto de atingir $10 \%$ a $20 \%$ a mais do número de páginas 
pretendidas. Nesse momento, o jogo de Lego está concluído e grande parte da construção está feita.

Há já algum tempo que a forma conta muito mais que o conteúdo, a marca mais que o produto. Para o estudante, a conceção de um belo trabalho corresponde a um texto cujo design implica a existência de parágrafos com o mesmo tamanho. E esse tamanho é exatamente igual ao da página do ecrã, isto é 12 a $15 \mathrm{~cm}$ de altura. Por isso, o estudante vai cortar os parágrafos demasiado longos e aumentar os que lhe parecem demasiado breves de forma a obter um documento elegante. Em seguida, vai aplicar-se na uniformização do tamanho dos carateres e na apresentação geral, escrevendo frases de transição entre os parágrafos, reescrevendo algumas passagens que não lhe convêm. Não se esquecerá da página de agradecimentos, da bibliografia e de entregar o seu trabalho, convencido de que terá feito uma boa síntese. Deste modo, os nossos estudantes já não aprendem verdadeiramente a elaborar os conhecimentos, a estruturar o seu pensamento, a destacar certos conceitos, mas antes a produzir esse objeto físico que se chama "monografia" ou "tese".

O modo de produção que acabámos de descrever já não lhes permite realmente distinguir o importante do acessório no sentido de lhes atribuir um espaço diferente. Como dar a entender que a forma está ao serviço do conteúdo, que é um simples meio relacional entre o estudante e o professor? É certo que existem ainda estudantes que têm vontade de realizar por si próprios esta prova intelectual de redigir uma monografia. Se o professor tiver a sorte de ter bons assistentes, ou se tiver tempo para receber o estudante individualmente ao longo do trabalho, então o estudante deverá modificar tanto quanto possível o seu índice para responder às novas exigências que the forem colocadas. Se assim não for, o professor viverá sempre na angústia de ser enganado pelos seus estudantes e terá que ler os trabalhos dos estudantes como se fosse um alfandegário. É fastidioso e entristecedor. 


\subsection{A tentação do plágio no doutoramento}

Quando os estudantes de doutoramento têm que começar a redação do seu manuscrito, as falhas do sistema de formação que atrás descrevemos vão com certeza refletir-se de modo flagrante. Porque num doutoramento, é realmente exigido aos doutorandos mostrar que estão em condições de fazer progredir o conhecimento. Ora, se os seus estudos anteriores não os prepararam para essa prova de escrita de um manuscrito "autêntico", como estariam à altura de realizar uma tese de doutoramento?

Mas a organização está claramente menos à vontade para tratar destes casos cada vez mais frequentes. Se é fácil excluir um estudante de mestrado apanhado em flagrante delito de plágio, a possibilidade de o mesmo acontecer no caso de doutoramentos é bastante mais delicada. Com efeito, um doutoramento implica presidências de júri, júris com vários membros eminentes, investimentos importantes, tanto do ponto de vista financeiro, como do ponto de vista do tempo despendido por parte dos diversos intervenientes. O que acontece com muita frequência é que cada um tenta mandar a bola para os outros. Num estudo específico levado a cabo junto da comunidade de académicos, os inquiridos traçam um quadro bastante negro da situação, indo ao ponto de exprimir o seu receio de se estar a pôr em causa o futuro da ciência: "Não acho que se trate de uma particularidade individual, mas quem se cala consente e toda a comunidade científica deve sentir-se atingida por este flagelo". Mesmo assim, eles próprios têm dificuldade em pôr-se pessoalmente em causa. A maioria dos inquiridos está consciente do problema de atribuição de títulos de doutoramento com base em teses complacentes, mas descartam a responsabilidade própria, fazendo-a recair exclusivamente sobre o orientador da tese. Um dos inquiridos exprime-se do seguinte modo: “O júri é certamente responsável pela validação da originalidade da investigação submetida para a obtenção do título de doutor, mas ele 
não está vocacionado para verificar a aquisição dos valores éticos. Esse é o trabalho dos orientadores de doutoramento ou mestrado e da sua universidade". No entanto, quando aceitamos ser membros de um júri de doutoramento ou presidente, nunca é por solicitude para com o doutorando, mas sim por amizade - real ou política - para com o orientador de tese. Logo, conhecemos esses colegas e sabemos muito bem o que podemos ou não esperar, porque, na nossa profissão, tudo acaba sempre por se saber. O orientador laxista, ou aquele que orienta dezanove teses com fraco acompanhamento, são perfeitamente conhecidos na comunidade. Mas que dizer do amigo que nos convida para uma defesa? O presidente do júri de tese, tal como os seus membros, não tem pura e simplesmente meios para verificar as qualidades éticas de um candidato: "Os júris de tese são muitas vezes momentos de descontração em que vamos encontrar colegas, almoçar com eles, arejar o fato e as insígnias bordadas, dar um ar de solenidade... Não é nem o momento, nem o lugar para causar problemas aos colegas".

Porque aquilo que é pedido ao júri é avaliar um documento e não o futuro do seu autor: "Não é ao júri que compete julgar se um doutorando aprendeu a ética da profissão; não é mais do que um júri de exame ou de uma etapa da escolaridade e como tal não deveria preocupar-se com essa questão (a não ser que os membros do júri desconfiem de que houve plágio na própria tese)”. Ou ainda: “Tanto quanto me é dado saber, nenhum presidente de júri de tese (eu próprio incluído) efetua esse género de verificação externa à avaliação da tese. O júri avalia um documento, não avalia a trajetória futura do seu autor”. Então, que fazer quando se dá conta um pouco tardiamente de que se está perante uma tese complacente? $\mathrm{Na}$ universidade de Toulouse, aconteceu que um membro do júri de uma tese que ia ser defendida e para a qual já tinham sido marcadas as provas públicas, identificou um plágio flagrante. Pediu-se então à pessoa plagiada que apresentasse queixa e desse modo foi possível 
recusar a tese in extremis ${ }^{17}$. Falámos longamente com o autor da tese anulada. Para ele, nunca se apercebeu de que estava a cometer plágio porque o seu orientador de tese lhe tinha dito substancialmente que, se, como era seu desejo, queria fazer carreira em empresa, devia rapidamente concluir a tese. Garantiu-nos nunca ter tido qualquer formação sobre plágio. O seu conselheiro de imagem (sic) escreveu-nos o seguinte: "Ele é muito ativo e o seu tempo disponível é muito limitado. Sinceramente, acho que ele deve ter pedido a um assistente para efetuar certas pesquisas por ele e para lhe preparar a montante, sob as suas orientações, certos trabalhos... estou horrorizado de constatar que o respeito da propriedade intelectual não é ensinado ou praticamente não é tratado no ensino superior".

Assim, face a um caso flagrante de uma tese complacente ${ }^{18}$, é muitas vezes o medo - ou o fatalismo - que impede os nossos respeitáveis pares de reagir a este problema. O seguinte trecho ilustra isso mesmo: "Um dia, o Presidente da minha universidade (atualmente já aposentado) contou-me ter ido a um júri de tese de um estudante que tinha plagiado um capítulo inteiro de um trabalho (em biologia). Perguntei-lhe o que ele fez. A sua resposta: "nada, era demasiado tarde... teria sido um golpe muito duro para o orientador da tese que é meu amigo...."

Quando, há alguns meses, eu me mostrei chocada com a atitude complacente de um júri relativamente a uma tese que não apresentava garantias de domínio da literatura sobre o assunto, foi-me ripostado de forma irónica: "Mas toda a gente sabe que existem teses de

\footnotetext{
17 Ver o nosso caso "Mesmo a tempo", maio 2012: http://responsable.unige.ch/index. php?main=b-29-21

18 Tese complacente: Atribuição de um título oficial de doutor por uma tese que não o merece, porque o manuscrito não corresponde a um conhecimento suficiente do domínio em causa, e/ou porque demonstra ausência de originalidade do pensamento, e/ou porque evidencia plágio textual e/ou de modelos apresentados, e/ou análises fraudulentas.
} 
complacência há já muito tempo nesta faculdade!” E nem sequer se tratava de uma pequena universidade desconhecida.

Estamos, pois, de regresso à premissa do problema: estes colegas consideram o seu papel na perspetiva de uma lógica de causalidade da ordem do acontecimento. O acontecimento é, obviamente, o da atribuição de um título de doutor mediante a entrega de uma tese manuscrita. O acontecimento inscreve-se numa linha temporal que vai do passado até ao presente. Desde logo, os membros do júri, incluindo o presidente, não têm o mandato de examinar o futuro do candidato. No entanto, são portadores dessa responsabilidade. Com efeito, o título de doutor consagra o direito de uma pessoa aceder a um certo poder no quadro da investigação e do ensino. E nós não podemos, ao mesmo tempo, pretender ser exemplo de moralidade nos nossos trabalhos e nos nossos laboratórios e agir com indiferença relativamente às teses de complacência validadas pelos nossos colegas.

No caso em que uma tese comporta provas tangíveis de plágio, tudo poderia parecer simples porque há aí uma prova factual. E no entanto nada é certo, como acabámos de ver, tanto por razões societais como organizacionais ou individuais. Tentemos então imaginar o que se passa quando uma tese de complacência é simplesmente nula em termos de originalidade ou muito pouco trabalhada. $\mathrm{Ou}$ ainda uma situação em que o plágio da literatura ou dos modelos é acompanhado de fraude científica ao nível dos dados do terreno ou dos resultados experimentais. Correndo o risco de parecer cínica, podemos assegurar a todos os orientadores de tese relativamente aos quais se descobre a posteriori que um dos seus antigos doutorandos plagiou um artigo científico que este terá certamente adquirido maus hábitos ao longo do processo de redação da tese. Ou melhor ainda, que os quatro ou cinco anos dedicados à aprendizagem de uma profissão não foram suficientes para corrigir os problemas de ética adquiridos anteriormente. Quanto àqueles que plagiaram de forma clara nas suas dissertações, há grandes probabilidades de 
terem também falsificado os dados ou as provas científicas. De facto, estes dois comportamentos ancoram numa mesma base de ausência de valores e de desconhecimento das nossas normas académicas.

Dentro de alguns anos, teremos que conviver com investigadores que vão conservar os seus comportamentos de plagiadores contraídos ao longo da sua vida de estudantes. E essas pessoas acabam sempre por repetir os comportamentos adquiridos. Existe uma forma de vício nos comportamentos de plágio que leva os seus autores a plagiar ou a autoplagiar-se por simples desconfiança relativamente ao sistema que nunca os integrou totalmente. Perante os imperativos de publicação é demasiado tarde e as derivas que observamos no dia a dia prejudicam tanto a publicação científica (recusa de artigos, processos...) quanto a reputação dos nossos estabelecimentos quando os casos de desvio atraem a atenção dos media.

\subsection{A tentação de reagir}

Não é nosso propósito incentivar a sanção ou a exclusão. É demasiado tarde para procurar apenas aplicar regulamentos e leis, por melhor redigidos que eles estejam. A variante entre países e estabelecimentos é considerável, e como tal este tipo de regulamentos está disponível em diversos sites institucionais. O que aqui pretendemos é propor algumas pistas que permitiriam aos estudantes tomar consciência dos seus comportamentos de plágio.

Quando chegam à universidade, os estudantes de hoje já estão formatados para copiar e colar textos. É, pois, essencial repor rapidamente o papel da biblioteca como lugar central das nossas instituições. Se a biblioteca do estabelecimento de ensino não disponibilizar as fontes documentais das revistas em linha, haverá poucas probabilidades de os estudantes se darem ao trabalho de ler os originais dos artigos que citam. Se, pelo contrário, o estabelecimento de ensino 
tiver uma dimensão suficiente para ter recursos que lhe permitam beneficiar de um bom serviço de biblioteca, é provável que tenham sido previstas sessões de formação obrigatórias para iniciar os estudantes na investigação documental, na consulta das revistas em linha, na arte da citação. Assim, na universidade de Genebra, os estudantes devem seguir um ensino obrigatório, validado por um teste, para compreender como utilizar os recursos em linha. É lamentável que o mundo das bibliotecas e o do ensino funcionem tantas vezes de modo independente. Ao participar no desenvolvimento das bibliotecas, os professores podem ajudar a organização a adaptar as suas formas de trabalhar às exigências do século WEB.

Naturalmente, a título institucional, é essencial enunciar claramente as diferenças entre plágio, batota e fraude. Importa lembrar os nossos valores de criação e de difusão de conhecimentos a fim de afirmar a igualdade de oportunidades e o mérito individual. É ainda imperioso que a instituição reforce a crença na norma de avaliação dos conhecimentos adquiridos, insistindo no tratamento de equidade. Mas trata-se também de demonstrar que cada um está em condições de confrontar qualquer plagiador com o que está regulamentado a fim de que a falta seja punida de forma justa e exemplar. Mas isso significa que cada um saiba gerir os comportamentos plagiadores (os seus, os dos que lhe são próximos, os das instâncias externas) a nível individual e institucional. A clarificação dos procedimentos de instrução dos casos de plágio, o conhecimento das composições de integridade sólidas e rápidas de exame dos casos de fraude tornam-nos atentos ao facto de o plágio poder constituir um problema.

A outra pista parece-nos incontornável, pelo menos na Europa onde a lei o autoriza. Trata-se de anunciar claramente aos estudantes que o estabelecimento que frequentam colocou à disposição dos seus professores um software de deteção das similitudes com textos disponíveis na web ou descarregados pela empresa que efetua o controle. Poder-se-á, com certeza, contestar os limites dos softwares 
de deteção, mas o seu efeito dissuasor é incontestável. Aquando da entrega do trabalho, o estudante preferirá entregar o seu trabalho em papel ou em PDF, pois sabe que um documento entregue em formato eletrónico pode ser mais facilmente controlável. Ora, é praticamente impossível um documento final estar completamente isento de plágio, atendendo ao modo de realização do trabalho.

Uma pista essencial de reação ao plágio situa-se no seio do próprio ato pedagógico. O professor pode, no próprio âmbito do seu ensino, prever a possibilidade de ensinar aos seus estudantes a criar textos com a ajuda de um dos múltiplos mapas heurísticos realizáveis graças aos softwares gratuitos, disponíveis na rede (ex. "Mind-manager"). Não é mais do que conceber as monografias de acordo com o procedimento heurístico que os próprios estudantes utilizam desde a escolaridade básica sem o saberem. Isso implica, é claro, que o professor tenha dedicado uma sessão das suas aulas a fazer descobrir aos estudantes o modo de elaborar um conhecimento com base na interligação de conceitos. O professor vai descobrir com alguma surpresa que os estudantes, na universidade, não dominam realmente as quatro etapas da escrita, a saber: classificar (precisar a ordem e estabelecer paralelo), opor (para contradizer ou retificar uma ideia), ligar (mediante a identificação de causas ou consequências), desenvolver (introduzir, acrescentar, atenuar, concluir). Lembremo-nos de que o estudante tem direito a um feed-back relativamente ao seu trabalho. É isso que o faz compreender que o exercício pedagógico não consiste em dar-lhe uma nota que sancione o seu sucesso ou o seu fracasso, mas antes formá-lo do ponto de vista cognitivo.

Uma pista que continua ainda amplamente por explorar diz respeito à possibilidade de levar a cabo seminários de aprendizagem de uma ética pragmática sobre as competências informacionais a adquirir (fiabilidade e validade das fontes em situação de obesidade informática) antes de avançar para a escrita de uma monografia. Estas competências numa ética pragmática, relativas ao saber-fazer 
e ao saber-ser do investigador, adquirem-se durante os anos de formação doutoral. No entanto, seria, com certeza, utópico querer formar para essas competências de ética pragmática todos os doutorandos: atendendo ao elevado número dos mesmos, arriscar-nos-íamos a dar-lhes apenas uma fina camada de verniz do conhecimento. Além disso, constatámos que os estudantes que se inscreviam nos nossos cursos no quadro da Conferência Universitária da Suíça Ocidental (CUSO) o faziam por iniciativa própria e não incitados pelos seus orientadores de tese. Pelo contrário, seria realista formar alguns doutorandos com vista a assegurar a passagem do testemunho em primeiro lugar junto da comunidade dos doutorandos e em seguida enquanto professores-investigadores na sua futura carreira. Essas "pessoas-testemunho" estariam aptas, no final do nosso "programa", a analisar os casos de presumíveis faltas de integridade em todas as suas dimensões e de modo desapaixonado. Para sermos mais concretos, estas "pessoas-testemunho" de integridade científica saberiam distinguir os problemas de moral, deontologia e ética, tanto do ponto de vista individual como coletivo. Saberiam ainda partilhar as suas análises, agindo não como observadores ou caçadores de fraude, mas antes como pessoas vigilantes da integridade académica.

\subsection{Conclusão}

Numerosos dirigentes de estabelecimentos universitários não estão alinhados com a mudança que tem vindo a acontecer e ficam confinados ao seu universo cultural. Quando começámos a efetuar as nossas pesquisas-intervenção sobre o tema do plágio, encontrámo-nos com numerosos dirigentes de estabelecimentos ou diretores de revistas e de associações que aceitavam mal que alguns professores denunciassem as monografias ou as teses que apresentavam evidências de plágio. Alguns dirigentes de estabelecimentos, pelo contrário, têm 
no entanto muita coragem: tratam com firmeza os casos que lhes são submetidos, pondo prontamente em campo comissões de sábios e fazendo cumprir as sanções pronunciadas. Sob a sua liderança, os procedimentos tornam-se transparentes e os queixosos, bem como os faltosos, têm acesso a todos os dados, e podem dizer o que pensam da organização e da análise. Em todas as comissões desta natureza em que fomos intervenientes, tivemos que assinar um protocolo de acordo de não-difusão das informações sensíveis.

Deste modo, a luta contra o plágio intensifica-se. Mas o nosso cartesianismo conduziu-nos durante muito tempo a isolar as fraudes dos nossos estudantes das fraudes dos investigadores, a separar o prevaricador do seu orientador e este dos seus colegas... quando, na realidade, todos estão implicados. Até ao doutoramento, um estudante pode ser considerado como estando isolado face ao seu ato. O culpado ideal, de certo modo, visto que não mancha mais ninguém a não ser ele próprio. O mesmo não acontece no doutoramento. As "teses de complacência" são uma realidade com a qual se confrontam tanto os indivíduos como os laboratórios, os estabelecimentos de ensino superior, e tanto os orientadores de tese quanto os membros do júri. Na verdade, o comportamento plagiador diz respeito a muitas pessoas que veem, não veem ou não querem ver os factos. Atualmente é preciso admitir que os procedimentos postos em marcha no século passado estão totalmente ultrapassados, porque os termos da comunicação, do poder e da ciência se modificaram. Os procedimentos são obsoletos e paralisantes; os nossos valores, esses permanecem idênticos. Temos que ser firmes nos nossos princípios morais pessoais e nunca sacrificar a nossa responsabilidade no altar dos princípios circunstanciais. Reapropriar-se de um sistema académico que traiu um grande número de pessoas entre nós, reinventar as suas normas e as suas regras em conformidade com a revolução do conhecimento que se produziu desde o aparecimento da $W E B$ exige-nos alguma coragem. 


\section{5 \\ FRAUDE ACADÉMICA DISCENTE E CONTEXTO MORAL}

Hermano Thiry-Cherques

Fundação Getúlio Vargas

bttp://dx.doi.org/10.14195/978-989-26-1123-5_5 
(Página deixada propositadamente em branco.) 


\subsection{Introdução}

Dentre as transgressões éticas menores, o ato de fraudar (lat. fraudatis ) ou de frustrar pessoas e descumprir deveres morais é tematizado em três instâncias: a tipificação do agir fraudulento; a contextualização do agente fraudador, no caso os estudantes universitários; e a entidade fraudada, pessoa, grupos ou instituição, no caso a academia como preposta da ciência.

Enquanto ação transitiva a fraude académica discente envolve ${ }^{19}$ : uma postulação da parte do fraudador que tem uma implicação falsa; o acreditar por parte da instituição académica fraudada no que julga ser verdade e efetuar ações baseadas nessa suposição; a implicação de danos da ação fraudulenta para a ciência e para a sociedade.

As formas de coibir a fraude académica discente tendem à intimidação e ao ultimato num extremo e à complacência tolerante no outro. Neste ensaio trago à discussão a possibilidade de diminuir a sua frequência e intensidade mediante o cancelamento ou atenuação das suas causas, dos móbeis que a induzem.

A fraude é o género, a académica a espécie, o discente o caso. Procurarei estabelecer um vínculo entre estas três esferas. Na primeira parte do texto exponho o que julgo ser comum às diversas correntes do pensamento ético contemporâneo. Em seguida apresento a definição dos casos mais frequentes de fraude em face do conceito basilar de academia. Na segunda parte discuto os indutores condicionantes

19 Ver resumo de David G. Mills (2003). 
das fraudes discentes. Concluo com uma sugestão sobre a forma de atenuar os seus efeitos e de diminuir a sua ocorrência.

\subsection{A ética}

Inicio com um resumo do que penso ser o consenso sobre as questões éticas nos dias que correm. Procederei por clivagem simples, partindo do ponto mais abstrato, que vem a ser a visão que a filosofia entende sobre o ser humano. Esta é uma síntese pessoal, daí a não citação de fontes, autores e correntes de pensamento.

A ciência moral da atualidade segmenta o ponto de vista das escolas filosóficas em duas vertentes. Uma, mais tradicional, vê o ser humano como um indivíduo situado em uma totalidade, em um corpo social uno. Outra, posterior à virada do século xx, vê o ser humano como pessoa situada espaço-temporalmente em uma associação mutante e de perfil irregular. O ponto de vista mais tradicional, que entende o ser moral como indivíduo particular, como o ente limite da divisão de uma totalidade, é hoje minoritário se comparado ao entendimento do ser moral como pessoa singular, o ente primário de uma sociedade. Desta evolução ou preferência resultam duas implicações: a pouca serventia hoje atribuída ao discurso sobre a conduta do ser humano em abstrato, isto é, sobre a ética normativa; e a utilidade atribuída à busca do entendimento da moralidade em termos de entes psíquicos imersos em uma cultura, isto é, em termos da eticidade das pessoas reais em sociedades e períodos estipulados.

Seguindo-se esta forma de ver, que é maioritária, mas não é exclusiva, tem-se que a definição que adotamos sobre o que vem a ser uma pessoa - o ser humano na sua integridade biológica e intelectual - é a chave para discorrer sobre os fundamentos da moralidade. A reflexão filosófica atual, incitada pelos avanços das ciências particulares, notadamente os das ciências psi e os das neurociências, veio 
maioritariamente a considerar como atributos essenciais da pessoa, além da faculdade do juízo racional, a autoconsciência e as faculdades de simbolizar e de comunicar. Este consenso ou quase consenso instrumentalizou a filosofia para equacionar problemas como os do aborto (o feto é uma pessoa?), o da eutanásia (uma pessoa tem o direito e capacidade de escolher a própria morte?) e assim por diante.

A análise do fenómeno da fraude académica, a que procedo neste texto, encara-a sob a ótica da reflexão ética contemporânea; isto é, não focada no aluno abstrato, universal, mas em entes racionais particulares dotados de autoconsciência e da capacidade de ação simbólica, ou, mais simplesmente, do domínio dos atos de fala. Em outros termos, a análise considera o fraudador, a fraude e o fraudado como entes situados, contextualizados.

A verificação que procedo na apreciação da fraude académica é, pois, situada espaço-temporalmente, posicionada em uma cultura dada. De novo aqui existem duas abordagens distintas. A mais clássica situa a pessoa moral em uma totalidade natural ou criada, a natura naturata, constante e imutável em sua essência. A mais contemporânea situa-a em um meio fluido e mutável, entendendo-se cultura como o conjunto de bens e valores dados em um espaço-tempo que construímos e reconstruímos e que nos condiciona. $\mathrm{Na}$ perspetiva mais tradicional temos o ethos, o caráter, a forma de ser constituída. Na perspetiva que adoto temos o ethos como a conduta, constituindo a cultura ou maneira de existir e sendo constituída por esta mesma cultura, por esta mesma maneira de existir determinada.

Para entender o espaço-tempo moral com que lidamos devemos proceder a uma terceira clivagem, não mais excludente, mas agora seletiva das caraterísticas e problemas dominantes do meio universitário ocidental do nosso tempo. Um meio sabidamente complexo e controverso, mas mediado por três dentre inúmeras questões e problemas da atualidade: a liberdade, a individualização e a racionalização. 
A inconstância da vida social e a questão da liberdade - eterna querela entre o livre e o servo arbítrio - são as marcas mais profundas da contemporaneidade. Como sustentar qualquer posição que seja em um mundo que reconhecemos em evidente reconstrução? Basta vermos as mutações na forma e na apreciação do erótico para constatarmos que qualquer perspetiva que possamos ter sobre o corpo, sua prática e sua imagem caducará em pouco tempo. No que se refere à mente, como sustentar que somos livres para escolher depois da psicanálise, do advento do marketing e dos avanços das ciências da mente? Por outro lado, dir-se-ia o mesmo da liberdade depois da democratização não só política, mas dos costumes e, principalmente, do livre acesso às informações? Discutir a fraude implica inquirir sobre até que ponto alguém é livre para copiar, para tomar emprestadas ideias, para se promover a si e aos amigos, para fabular e falsear, etc. Estas dúvidas sobre a liberdade conduzem a outras, entroncadas no problema da individualização.

A individualização moral se coloca sob ângulos: o da autodeterminação e o da autonomia. A autodeterminação refere à aspiração, que data dos gregos, da autarkeia, do bastar-se a si próprio, da liberação das inquietações do corpo, da mente e das convenções sociais, excluída a integração na polis; isto é, excluído o isolamento social. A autonomia se refere à busca da liberdade individual, do autogoverno. É expressa cruamente no preceito moral pragmático: "eu tenho o meu interesse, você o seu: mostre-me que o seu interesse é do meu interesse e eu me ocuparei dele". A dúvida que emana das duas formas do individualismo moral é de limite: em que ponto a autarkeia e a autonomia lidam com o egocentrismo e com o insulamento cultural? Esta dificuldade em precisar um limite que não seja puramente normativo nos leva a inquirir sobre a fronteira de determinação (os términos) e da lógica (a razão de) da fraude académica.

A racionalização em termos da ética é a redução do humano a uma ideologia, a edificação de uma lógica sobre uma ideia não fundamentada. Seja esta ideia a da naturalização do mercado, ou a do 
bem comum, ou da solidariedade, ou a do bem estar, o que sustenta uma ideologia é, por definição, uma ideia matriz, uma representação mental abstrata e, muitas vezes, quimérica. Toda a racionalização estabelece um paradigma. Pois o paradigma hoje em voga na esfera académica é o da aferição numérica, a da subordinação de tudo à ideia reducionista de que o não mensurável é especulativo e, por isto, deve ser transposto ou abandonado. A dúvida que aqui se nos apresenta na apreciação da fraude é a de como medir não a conduta humana, mas a sua causalidade e a sua intencionalidade. Em que pesem todas as estatísticas que possamos estabelecer, do ponto de vista moral pouco ou nada importa saber quantos fraudadores há e quantas infrações foram cometidas. O que importa discutir é quem fraudou a quem e por que razão, questões irredutíveis a índices. Não existe uma entidade como a fraude 3,2t, onde t é o índice diferido de transgressão moral.

\subsection{As fraudes académicas}

A primeira esfera de entendimento da fraude académica discente é, ou melhor, são os diversos tipos de fraudes no contexto analisado. Na relação que se segue, arbitrei denominações genéricas para fraudes de mesmo tipo. Inicio com as mais frequentes, relacionadas à cópia ou reprodução. Seguem-se as de pilhagem, as dirigidas a promover sem mérito, as de conteúdo e as que falseiam os resultados do esforço de investigação. A listagem é longa. Baliza a argumentação final, mas é prescindível para a sua compreensão.

\subsubsection{Fraudes de reprodução}

O plágio é certamente a mais frequente das fraudes académicas. $\mathrm{Na}$ sua forma direta, consiste em copiar uma fonte, muitas vezes o 
trabalho de um colega (a "cola", no dizer brasileiro), sub-repticiamente, sem que a fonte ou instância fraudada - a instituição ou a ciência em abstrato - tenham conhecimento. As diversas formas de plágio apresentam dois traços relevantes para a devida apreciação moral. A primeira é a sua característica atenuante, que o diferencia do roubo e do furto, já que a fonte permanece intocada e na posse de quem detinha originalmente o original copiado. A segunda é a da sua ambiguidade. Nem sempre o plágio foi ou é julgado negativamente. O King Lear de Shakespeare é uma cópia de trechos inteiros reproduzidos verbatin do anónimo King Leir.

$\mathrm{Na}$ forma do centão ou da rapsódia, o plágio consiste em copiar trechos de diversas fontes compondo-as em um texto "único". Na forma paráfrase, consiste em escrever a mesma coisa que uma fonte, mas de maneira diversa. Na forma autoplágio, consiste em reapresentar textos e pesquisas com roupagem diversa da original, ou das anteriores, em vários casos. Nenhuma destas formas é reprovável em termos absolutos. O plágio centão é usual na poesia e na música. Um centão é um conglomerado em que o escritor reordena versos de outro ou de outros poetas para criar um poema inteiramente novo. Já foi muito popular. Antônio compôs uma versão em forma de epitalâmio (hino nupcial), com versos de Virgílio, para celebrar as bodas de Valentiniano. O que tornava reprovável os centões e as paráfrases era o serem compostos principalmente de poemas indecorosos. Fora das artes, o centão e a paráfrase são, desde sempre, estratégias de aprendizagem dos trabalhos escolares, o que induz a que hoje, graças ao Google e a Wikipédia, os discentes, treinados desde a infância, estejam aptos a compor alegremente relatórios e textos diversos. A fraude académica aqui não está na composição, mas no não reconhecimento das fontes. Já o autoplágio pode ser considerado como instrumento de aperfeiçoamento e de progresso. A Investigação sobre o entendimento bumano, de David Hume, é uma reescritura do Tratado da natureza humana, que ele considerava uma obra juvenil. 


\subsubsection{Fraudes de pilhagem}

O esbulho, a apropriação de títulos e ideias de outros, embora eticamente insustentável, curiosamente não recebe a mesma atenção legal do plágio. Na maioria dos países não existe copyright para conceitos que não foram legalmente registrados. A ideia de Guerra e Paz é de Petrarca (Pace non trovo e non ho da far guerra...), não de Tolstoi. Dan Brown fez rios de dinheiro copiando o tema de dois autores ingleses de pouco êxito. Processado, venceu tranquilamente a causa. Publicações anónimas ou sob pseudónimo podem ser legalmente copiadas e títulos não estão protegidos. Se der a este texto o título de Código da Vinci ou O capital, não serei incomodado.

As fraudes de pilhagem incluem ainda a falsa adição e a deturpação. A falsa adição, caracterizada pela continuação ou complementação sem conhecimento do autor ou do recetor de um texto, é prática antiga, como prova o incompetente terceiro tomo do Quixote. A deturpação, desvirtuamento, distorção ou a deformação do discurso, fazendo o autor dizer o que não disse, se tornou comum em textos digitais, que podem ser alterados e redistribuídos facilmente. Não é uma prática nova. O que se afirma no texto bíblico é ser mais fácil uma corda - e não um camelo - passar pelo fundo de uma agulha. Uma fraude milenar de tradução, que ninguém se ocupa em corrigir.

\subsubsection{Fraudes promocionais}

As mais comuns das fraudes promocionais são a burla das citações cruzadas de grupelhos discentes e docentes que se citam mutuamente a fim de aumentar os respetivos índices, e o compadrio, o conluio, a mancomunação entre discentes e docentes, 
que vai desde o fenómeno conhecido como "banca amiga" até à glorificação de trabalhos torpes e pesquisas não fundamentadas. Junto à autopromoção, a ação de alabar, do lat. alapo, soprar, no caso soprar a própria vela, se tornara tão comum que é julgada moralmente aceitável.

\subsubsection{Fraudes de conteúdo}

As fraudes de conteúdo são as menos visíveis, e, em termos da episteme, as mais graves. Compreendem o recurso ininteligibilidade, o ressuscitamento de textos e uma série de falácias.

O texto ininteligível é, de regra, assente sobre cálculos que poucos dominam, como o cálculo vetorial, ou de termos que parecem precisos, mas cuja significação não se liga aos referentes examinados. É uma fraude tornada célebre pelo físico Alan Sokal, da Universidade de New York. Indignado com a complexidade e a forma tortuosa, às vezes ininteligível em que as ideias de Deleuze e de Guattari são expostas, Sokal escreveu um artigo, intitulado "Transgredindo fronteiras: para uma hermenêutica transformadora da gravidade quântica" que foi publicado pela prestigiosa Social Text(Sokal, 1996). Em que pese a seriedade da revista, tratava-se de uma paródia, polvilhada de absurdos, entre eles a sugestão que o valor da constante $\pi$ muda segundo as atitudes da época. A brincadeira demonstrou como parte da reflexão pós-moderna tem mais valor estético do que lógico. Como autores das ciências humanas e sociais do pós-guerra a esta parte fazem uso de conceitos que não compreendem, como /infinito/, /função/ e /catálise/, elegantemente encadeados para se parecerem com teorias profundas.

O ressuscitamento de textos é uma das práticas mais difundidas. Consiste basicamente em tomar um mesmo tema, dados, método e desenvolvimento para apresentar conclusões ligeiramente distintas 
em vários textos. O truque está na conversão de título, de terminologia e do estilo de redação dos textos.

Dentre as falácias, os recursos ao raciocínio verosímil, porém inverídico, o mais comum no meio académico é o do tipo ignoratio elenchi. A premissa do argumento é verdadeira, mas não é prova para conclusão. Por exemplo, nunca foi provado que do facto de enfermos com atitudes positivas ante a vida se sintam melhor, decorra que o bom ânimo contribua para a cura. A segunda falácia é a do falso dilema. No falso dilema, a alternativa /ou/ é entendida como incondicional. Como em /ame-o ou deixe-o/ ou em /quem não está a favor, está contra/. O dilema é falso sempre que existe uma terceira possibilidade, seja a neutralidade, seja a indiferença, seja, enfim, outra posição diversa das postuladas. A terceira falácia em que incorrem os trabalhos discentes é a do argumentum ad ignorantiam. Funda-se na ideia de que não existindo provas para sustentar uma posição, a posição é falsa. O argumento consiste em sustentar que não há alternativa às "verdades", e normas vigentes. É o mesmo que afirmar que uma vez que não é possível provar a inexistência das sereias, elas devem existir. A quarta e última falácia que citarei é a do primeiro modo das falácias causais, a post boc [post hoc ergo propter hoc, ou "depois disso donde devido a isso" - ou seja, sustentar que como $B$ sucede a $A, A$ é a causa de $B$ ]. A falácia consiste em considerar que uma singularidade, como a relação entre a renda do capital e do emprego tem permanecido constante, então ele é permanente. No ano que terminou, os dados da OCDE mostram que a constante não se sustenta, que, na verdade, é variável. Deixou uma legião de economistas perplexos, mas silentes. A falácia post hoc está por trás do raciocínio que leva a concluir que uma vez que todo banqueiro usa gravata se usarmos gravata seremos todos ricos. O engano aqui reside em que, as oscilações dos ganhos de capital e do trabalho, como a gravata e o dinheiro, são efeitos. Ambos ocorrem, mas um não é a causa do outro. 


\subsubsection{Fraudes de produto}

As fraudes de geração das pesquisas académicas tanto discentes como docentes, compreendem a fabulação, o falseamento, a contrafação e a formatação.

A fabulação, a invenção pura e simples de dados é a mais grosseira destas fraudes. Especialmente frequente em experimentos nas ciências humanas e sociais, decorre da impossibilidade de se replicar a situação espaço-temporal em que os dados foram coletados e da dificuldade em se garantir que os respondentes recordem as informações prestadas passados meses da data do experimento.

O falseamento ou deturpação de dados primários, ou sua simples invenção está muitas vezes baseada na multiplicação engenhosa. Consiste em multiplicar os resultados de uma pequena amostra por um número arbitrário. Quando bem feita, é difícil de ser identificada, já que o levantamento de facto foi feito e as informações efetivamente coletadas e sistematizadas.

A contrafação tem uma história venerável. Os mais antigos contrafatores que se têm notícia foram os evangelistas, apócrifos ou não, que copiaram a São Marcos, que, aliás, parece ter também copiado fragmentos de textos anteriores, como os encontrados nas cavernas do Mar Morto. Menos venerável, a falsa autoria, uma contrafação comum na literatura, comprovadamente utilizada por autores da estatura de um Alexandre Dumas, invadiu a academia. Na sua vertente atenuada consiste na contratação de assistentes ghost-writers. Na vertente mediana, na aquisição de pesquisas e textos prontos, incluindo-se dissertações e teses, hoje vendidas online a preços módicos. Na sua vertente mais deplorável, a contrafação da falsa autoria consiste na servidão imposta aos discentes que devem pensar e escrever segundo e para o seu feitor, uma abominação clara e abertamente incentivada pela academia e pelos órgãos oficiais de financiamento. 
A formatação, fraude que data dos monges medievais, que cristianizaram tudo o que podiam, é a forma ancestral do sistema de editoração: a harmonização ou redação de textos focadas nas exigências do mercado editorial. Prática que tornou possível que pessoas incultas e intelectualmente vazias, celebridades, bufões e magos, muito ignorantes ou muito ocupados para escreverem qualquer coisa, viessem a publicar desde best-sellers a textos científicos. Transposta para a academia, a editoração é oferecida graciosamente até por editoras de revistas científicas, que, claro, fazem da discrição o seu ponto de honra.

\subsubsection{Fraudes de generalização}

Por último, temos as fraudes decorrentes da vulnerabilidade da epistemologia da moda. As fraudes de generalização, que compreendem a estatística criativa e a generalização confirmativa.

A falcatrua representada pela estatística criativa mais grosseira consiste em estender o domínio dos resultados dos cálculos para além do que permite efetivamente a amostra. Deriva da consabida dificuldade de sustentar logicamente a generalização probabilística de caráter indutivo. O probabilismo é, em essência, generalizante. É dado a produzir uma gama infindável de generalizações a partir de associações parciais e imperfeitas entre variáveis (classe social e empregabilidade; lucro e sustentabilidade; produtividade e treinamento). Os discentes exploram o probabilismo em várias das suas fragilidades: 1) a da impossibilidade de controlar a interatuação dos fatores (as associações causais podem ser mera coincidência. Bertrand Russel gostava de citar a implicação do apito da fábrica de Manchester com o cotidiano de Cambridge); 2) a da impossibilidade de descrever o real de forma probabilística (a probabilidade de as pedras voarem em Marte, embora mínima, existe); 3) a do condicionamento na eleição 
das variáveis (trabalham exclusivamente com dados pré-existentes); 4) a variação espaço-temporal das condições no mundo social (o que foi facto nos anos 2000, não necessariamente o é hoje); 5) a multiplicidade de se aventar um número indefinido de explicações (teorias) que apreendam um mesmo fenómeno; 6) as associações, que deixam de lado exceções e particularidades; e 7) o facto de que o objeto observado pode ser uma singularidade.

A generalização confirmativa é similar à explicação estatística: estabelece uma relação não dedutiva entre premissas explicativas e uma conclusão. Por exemplo, se todo objeto que examinamos tem a propriedade $P$, e tem, igualmente, a propriedade $Q$, sustentar que todo e qualquer objeto que tem a propriedade $P$ tenha a propriedade $Q$. A inferência, no caso, é plausível, mas não é universalizável. Serve como suporte indutivo. $\mathrm{O}$ que distingue a generalização confirmativa da explicação causal e da explicação estatística é que a causal explica inteiramente porque o fenómeno explanandum se produziu, a estatística explica parcialmente (probabilisticamente) e a generalização confirmativa não o explica de forma alguma.

\subsection{A Academia}

Relacionadas as fraudes, passo agora à segunda esfera em questão: a academia.

As instituições de ensino superior, a corporação dos estudantes e dos docentes e as sociedades com caráter literário, científico ou artístico, hoje denominadas de academia, têm origem conceitual na escola fundada por Platão nas cercanias do jardim dedicado ao herói Academos.

A Academia foi mais do que um lugar. Académico foi e é o espírito, a disposição para adquirir e transmitir o conhecimento. Platão, sabemos por Aristóteles, aderira na juventude ao princípio heraclidiano 
de que todas as coisas sensíveis estão em perpétuo fluir de transformação e que, portanto, não podemos ter delas qualquer conhecimento. Não foi o desejo de resolver o enigma do Universo sensível que justificou a fundação da Academia, mas sim a necessidade da busca do saber, o exercício da episteme que esclarecesse a vida biológica, psíquica e social.

A Academia tinha o propósito de avançar na procura da sabedoria. Viveu da certeza socrática de que se os homens fossem libertados dos miasmas do preconceito e das falsas convicções veriam a verdade da vida. O seu processo educacional (educare é conduzir - duco, para fora $-e x$ ) foi o do desenvolvimento do ser humano em todas as suas potencialidades, foi o esclarecimento da Paidéia, da cultura pela educação constituída pelo legado de uma geração para a outra.

A Academia não pretendeu o saber funcional, mas a essência do saber como força dignificante da vida. Os dois sistemas educacionais que são a República e as Leis giram em torno das premissas filosóficas da crítica às potências educacionais do seu tempo, particularmente a sofística, a retórica e a religião. A Academia não se dedicou ao atual e efémero, mas ao ser, ao eterno (Platão, 1981). A "Teoria das Ideias" nada mais é do que a tentativa de desvendar o mistério de como objetos ideais do pensamento podem ser conhecidos. A resposta que dá é a da reminiscência, da anamnesis: podemos conhecer estes objetos pela reflexão, trazendo-os de novo à consciência. Os objetos ideais vêm do próprio intelecto, o conhecimento inconsciente, por um processo análogo ao que nos permite recordar algo que já conhecemos e que esquecemos.

Institucionalmente, a Academia não foi de modo algum um grupo em que um era o sábio e os outros se encontravam à procura das doutrinas ou dos serviços do mestre, mas uma comunidade de estudiosos com diferentes graus de desenvolvimento (Jaeger, 1979). As interpretações da "Sétima Carta" de Patão - escrita já em idade avançada, contra a podridão moral do "Estado do Governo dos Trinta" - 
não deixam dúvidas que ele, como a sua Academia, tinha o propósito de busca do conhecimento verdadeiro, do saber fundado, não do adestramento sofístico da conveniência.

Nos nove séculos que durou (387a.C. - 529 d.C.) a Academia muitas vezes deixou de observar este ideal. Depois da morte de Platão, a Academia Antiga (387-316 a.C.) dedicou-se ainda aos problemas sobre o homem e a existência, decaindo no final para a matematização pitagórica. Foi rendida pela Média Academia (316-241 a.C.), que também estudou a questão do conhecimento, mas que, impossibilitada logicamente de excluir a experiência sensível do saber, declinou, torando-se equívoca e probabilística. A Nova Academia (160 a.C. - 84 a.C. e, desfigurada, até 529), a de vida mais longa, que a substituiu, restaurou o dogmatismo, atribuindo valor gnosiológico à evidência. Ante a impossibilidade de fundamentar por evidência a ética, tornou-se, na sua decrepitude, eclética ao absorver o pitagorismo da Antiga e o probabilismo da Média academias. Ao cabo, foi sincrética, juntando a tudo isto o estoicismo e o peripatetismo que conformam a obscura amálgama de neoplatonismos (Cornford, 1952).

Este pequeno resumo dos zénites e nadires do ideal académico nos serve para precisar que o termo "fraude académica" não se refere aos ilícitos praticados contra uma organização ou grupo de organizações abstratas, mas ao ato de fraudar o ideal académico, expresso na episteme, na busca intencional e sistemática do conhecimento mediante a reflexão, a fundamentação, o diálogo e o convívio intelectual.

\subsection{Os indutores}

Até aqui expus uma visão razoável da ética no mundo contemporâneo, descrevi as fraudes e o contexto em que ocorrem e detalhei o quadro de referência moral que as circunscreve e as dicotomias 
que as explicam. Passo agora a examinar os possíveis indutores das fraudes académicas discentes e da forma de confrontá-las.

A fraude pode ser confrontada de muitas maneiras. As mais eficientes são aquelas que as inibem no nascedouro, mediante a supressão ou, ao menos, a atenuação dos seus indutores. Em um livro que presume a intenção de esgotar o assunto, o jurista Joseph Wells aponta como indutores da fraude as pressões psíquicas, económicas e sociais, a oportunidade e a racionalização no marco da cultura em que o ato de fraudar é praticado e julgado (Wells, 1997). Examinarei estes móbeis na forma que se apresentam face às dicotomias morais liberdade-condicionamento, individualização-equalização e racionalização-paradigma.

\subsubsection{A liberdade condicionada}

Talvez a maior contribuição de Michel Foucault para o entendimento do mundo contemporâneo tenha sido o esclarecimento de que a opressão que pesa sobre a sociedade não deriva exclusivamente dos sistemas de dominação instituídos — os governos, as igrejas, as corporações, etc. - mas de instâncias teoricamente insuspeitas, como a psiquiatria, a filosofia, as instituições, inclusive a académica. Em todas e em cada uma destas instâncias existem manifestos ou não, instituídos ou dissimulados, dispositivos - do poder, mas também do saber e da subjetividade - limitantes ou supressores da liberdade (Deleuze, 1990).

Desde meados do século $\mathrm{xx}$, principalmente a partir da obra de Arendt A condição bumana, sobre as condicionantes da cultura ocidental, que a questão da liberdade se equaciona pela busca e determinação do estatuto de pessoas e grupos com relação à sua origem, à sua situação social, profissional, económica, e assim por diante. Reduzida ao tema de que nos ocupamos, a questão da liberdade leva 
a inquirir em que medida a fraude discente resulta de uma opção livre e consciente ou de um ato condicionado pelos dispositivos sociais, de que o mais das vezes não se tem consciência.

Esta linha de indagação conduz a outra antiga querela filosófica: a que contrapõe a determinação natural à determinação cultural do agir humano. A oposição, estabelecida por Kant, entre a liberdade de escolha e a natureza constitutiva do instinto normal da espécie. A "natureza humana" abarca tudo o que é inato e espontâneo na humanidade, incluindo o que é próprio e superior à animalidade. Alia os instintos primários, comparáveis à função fisiológica, que resultam diretamente da estrutura primitiva do ser vivo e do automatismo adquirido que se tornou inconsciente. A fraude, neste caso, seria uma inclinação de uma existência que se determina a si própria, sem interveniência de uma causa externa.

Mas esta possibilidade de justificativa moral não se sustenta. O instinto, como queria Bergson (1986) se opõe à inteligência, ao propósito, à escolha que caracteriza a fraude. Atribuir a fraude à natureza humana seria afirmar o que não faz sentido, a saber: que a transgressão ética corresponde ou a tudo que é dependente da vontade - como diz Rousseau (1973): "tal é este puro movimento da natureza, anterior a toda reflexão" - ou à corrupção do natural, inato e espontâneo. Se fosse instintiva, a fraude seria a norma. Escaparia à ética e deveríamos entendê-la no marco improvável de uma etologia humana. O que poderia ser explicado pela natureza instintiva do ser humano seria a evasão do constrangimento desmesurado do meio em que vive. Um constrangimento que levasse à excitação dos desejos e à anulação das vontades individuais

Outra possibilidade é aquela em que Bernard de Mandeville (16701733), em sua Fábula das abelhas: vícios privados, beneficios públicos (1997), defendeu a dolorosa tese de que a sociedade vive em fraude, luxúria e orgulho, e de que a única forma de superar a má índole social é a de que cada indivíduo cuide apenas do seu interesse 
próprio. O esforço para ser bom e virtuoso colocaria o homem em oposição ao interesse geral e conduziria à destruição da sociedade. Adam Smith acolheu a tese de Mandeville para os bens económicos e a repeliu para os bens espirituais.

No seu rastro de Mandeville e de Smith, o liberalismo económico prega que o motor da moralidade é o altruísmo e a temperança e que o motor do progresso é o egoísmo e a cobiça. Não nota, ou finge não notar a improbabilidade da coexistência entre estas duas lógicas. Uma contradição que está na raiz da moralidade duvidosa dos que advogam a legitimação da fraude pelo imperativo de se atingir metas e índices. A instituição académica do Ocidente, originalmente emaranhada na vã tentativa de conciliar a liberdade da razão com a fé cristã, ganhou traços esquizofrénicos ao resvalar no propósito de fazer convergir o progresso do conhecimento e o utilitarismo económico. Instituiu aferidores materiais na tentativa de medir o avanço do conhecimento "útil". Decaiu ao produtivismo, a velhacaria mais tirânica do aparelho académico, que, sob o pretexto da contenção do ilícito científico, instituiu as publicações e citações como utensílio genérico de regulação, uma maquinação só comparável àquela gerida pela Igreja medieval. A regra que determina o que é ciência e quem a faz não tem o objetivo de ampliar o conhecimento, mas de preservar a quimera da mensurabilidade. Carregado da toxina botulínica, o sistema obtuso, que pretende medir o que por definição é incomensurável, vem degradando a alma da instituição académica. Bifronte como Janus, a academia no Ocidente dá-se ares. Repudia o denso e duradouro, interdita a descoberta, atem-se ao fait-divers e sufoca a inovação. Desconhece que a pior tirania não é aquela que interdita, mas a que obriga.

À dissociação entre pensamento e ação, entre a liberdade de conduta e a sua contenção pode ser atribuída parte do condicionamento que os dispositivos sociais impõem sobre os discentes. A instrumentalização mutilante da episteme anula esperanças e cria necessidades 
buropáticas. Legitima a fraude como instrumento emancipatório. O dístico "necessitas legem no habet", a esplêndida sabedoria da língua que herdamos e empobrecemos, permite duas interpretações: "a necessidade não reconhece nenhuma lei" e "a necessidade cria a sua própria lei”. Pressionados pela necessidade de sobreviver, de submeter-se à instituição que tudo regula e restringe, o discente tende instintivamente a fazer uso dos expedientes de que dispõe, ainda que de aqueles menos sustentáveis moralmente. Coloca a questão de perguntar em que medida as fraudes de reprodução e de pilhagem não seriam uma via de passagem, um meio de sair, de escapar de um mundo contraditório, hostil e injusto.

\subsubsection{A individualização equalizada}

Em pleno século das Luzes, o filósofo da educação Claude-Adrien Helvétius (Paris, 1715-1771), viu sua obra Do bomem, das faculdades intelectuais e de sua educação (Cumming, 2000) ser queimada por ordem da Sorbonne, da libertária Sorbonne. As alegações foram outras, mas quer me parecer que a instituição não pode suportar a verdade da assertiva de Helvétius que inspirará o Candide de Rousseau: ensinamos às crianças a moral que ninguém cumpre e que o adulto deve desaprender para sobreviver na nossa sociedade.

Sem poder se desembaraçar desta incongruência, o meio académico é estruturalmente controlador e avesso às exceções e aos excessos. O cômputo dos atores, dos discentes, docentes e administrativos, que alcança muitas vezes a casa das dezenas de milhares de pessoas envolvidas, e as demandas internacionais de padronização, que obedecem a critérios estranhos às culturas locais, parece não deixarem alternativa à equalização rasa de governança e procedimentos. Uma uniformidade que se contrapõe diretamente à episteme. Pior: que contradita o zeitgeist, o espírito do tempo. 
A sociedade que podemos considerar como sendo a nossa é a de uma classe média universalizada pós-pequeno burguesa que, simultaneamente, exalta e restringe a autarkeia. Uma sociedade que reverencia o empreendedorismo e censura o risco económico. A conquista da autonomia no cômputo da moral vigente é, para dizer o mínimo, espinhosa. Uma realidade comum a ideologias e regimes. O caminho que a minha geração acreditou ser emancipador, como o do festejado e ambíguo Che ("Hay que endurecerse, pero sin perder la ternura jamás."), terminou na idealização de um personagem que tirou a vida de dezenas de inimigos políticos. Ternamente. As iniciativas estudantis de 1968 na França, nos EUA e depois em todo o mundo que supusemos revolucionárias, desaguaram em meras reformas. Incitaram uma contrarreforma marcada pelo tolhimento do novo, pelo normativismo equivalente ao daquela outra, a inquisitorial. Sua mais clara expressão frauda a mais comezinha moral académica: é a escravização de estudantes, que devem pesquisar e redigir textos perfilhados pelos professores. As demais expressões do normativismo: currículos sedimentados, estruturas obsoletas, interdição da expressão individualizada instigam os discentes ao descompromisso com os processos e com os produtos da sua trajetória académica. A equalização normalizou a impudicícia. Enjeitados, desencantados, é possível que os discentes fraudem por desesperança de quem antecipa a partida.

Não por acaso uma fração considerável dos empresários de maior êxito na nossa época, dentre eles os icónicos Steve Jobs (falecido em outubro de 2011) e Mark Zuckeberg, não terminou a universidade (Issac, 2011; Rampell, 2013). A eventual imoralidade da fraude académica diz pouco aos estudantes deste nosso tempo que copertencem à cultura dos emancipados da titulação universitária, do Facebook, do Twiter, do LInkedIn. Culminâncias tecnológicas que irão desaparecer, mas que já mudaram a vida psíquica e social. As grandes universidades tentam se tornar "virais" com seus 
cursos online. Abraçam a superficialidade inutilmente porque não têm como atingir pessoas sem identidade profissional definida e que já sempre caminham à sua frente. Pessoas que investem seu tempo, seus recursos e sua vida, em startups, em redes sociais, em samarthphones, em tablets. Pessoas em permanente comunicação digital, pessoas que criam novos negócios, financiam-se por crowdfunding, comem produtos paleo. A imoralidade da fraude diz pouco também aos estudantes que pertencem à cultura dos indignados, dos manifestantes, dos occupy, ou como quer que se denominem aqueles que protestem sem um conteúdo determinado de reivindicação. Que pertencem à geração dos sem projetos, dos incodificáveis, dos irrotuláveis, dos que sentem (quase escrevi "dos que sabem") que o que aí está - normas, instituições, ideologias - está vencido, perdeu a validade.

Existe a possibilidade de que o descompromisso moral seja uma reação não só ao arcaísmo institucional, mas também à economia consumista, ao imediatismo do prazer, à subordinação ao útil e ao instrumental que vêm num crescendo alucinante desde meados do século passado. No entanto, pesando opiniões e expectativas, não restam dúvidas quanto ao divórcio entre o instituído e o vivido pelos discentes. Se tudo o que percebemos e declaramos é biograficamente determinado, se não podemos nos exilar do nosso tempo e da nossa história pessoal, cada pessoa supostamente organiza seu mundo segundo categorias de faculdade e estranhamento, de personalidade e sentimento, de intimidade e anonimato, de afastamento e de compromisso, seria de perguntar sobre em que medida o discente, fraudador ou não, imerso no espírito do seu tempo se sente comprometido com as instituições académicas. Decorre desta dúvida a questão de como reatar os laços de compromisso com um paradigma imposto, desbaratado tanto do espírito do tempo como do espírito da Academia. 


\subsubsection{A racionalização paradigmática}

Impor um paradigma é uma arbitrariedade. Estabelecer um paradigma académico é cometer o ato arbitrário de sustentar que o relevante é isto, e não aquilo, que a centralidade está nisto, e não em outra coisa. Impor um paradigma é desvalorizar o diferente. O paradigma é um exemplo, um modelo. O grego para-deigma, aquilo que se mostra ao lado, é a idealização que orienta o agir. É o exemplo a seguir, o exemplar eleito, seja uma pessoa, um grupo, uma ideia. O exemplo, lembra Agamben (2013: 18), é um caso particular do real, mas tomado como universal. O exemplo paradigmático é uma singularidade como outras, mas que não é definida por nenhuma propriedade particular. É protótipo que vale para todos os casos do mesmo género, o género em que se inclui como um mero caso dentre outros. Decorre daí que todo paradigma é falho. Algo que é e que não é ao mesmo tempo. Algo que parece genérico e atemporal, mas é particular e datado.

O paradigma positivista que aí está data do século xix. Eça de Queirós teve a ilusão de que estaria em vias de desaparecer:

\footnotetext{
"O positivismo científico considerou a imaginação como uma concubina comprometedora.... e fechou o homem em um laboratório a sós com a sua esposa clara e fria, a razão. O resultado foi que o homem começou a aborrecerse monumentalmente e a suspirar por aquela companheira tão alegre, tão inventiva, tão cheia de graça e de luminosos ímpetos... a esperança, quase a certeza... de que... ninguém mais com medo da ciência duvidará em correr aos braços da imaginação”. (Queirós, 1966)
}

Eça teve esta doce esperança em 1893. Uma esperança frustrada. O positivismo e a matematização de tudo continuam a assolar como forma paradigmática de razoabilidade. 
Desde o final do século xviII, o raciocínio matemático é um dos sustentáculos do pensamento ocidental. Nos tempos que correm tende a ser o único, fraudando o espírito académico. Traem a doutrina dos números de Platão, que está entre as àgrafa dógmata, as doutrinas não escritas, de que nos fala Aristóteles (1952), que colocou os entes matemáticos como pontos entre as ideias e o real sensível. Traem Hume, e praticamente todos os filósofos depois dele que negaram que o pensamento moral e o pensamento prático possam ser matematizados - "reason is and ought only to be the slave of the passions and can never pretend to any other office than to serve and obey them" - (Howson, 2000: 110). Traem Rousseau, que mostrou como e por que a vida só pode ser vivida de acordo com a natureza e com os afetos.

Ante esta violência contra o que deveria ser o espírito académico, não seria de se perguntar se parte das fraudes discentes não decorre do abandono forçado do que não pode ser numericamente demonstrado ou sequer discutido? Não seria o paradigma matematizante o grande indutor das fraudes de conteúdo, de produto e de generalização? Não seria de se perguntar se a tolerância com as fraudes nada mais é do que uma resposta evasiva da academia que tarda em abdicar deste paradigma?

\subsection{Tolerância}

A ilusão dos metafísicos, escreveu Nietzsche (2010), reside na sua crença na oposição dos valores. Os valores não se opõem na forma que creem os maniqueus. À coragem se opõe a covardia, mas também a temeridade. À fraude se opõe a franqueza, mas também o conformismo. Os valores morais, como quaisquer valores (Nietzsche, 1990), são criações históricas, conveniências sociais, heranças aprendidas. Sua hierarquia muda com o tempo e com a 
circunstância. Se e quando tolerada, a fraude académica discente o é por razões históricas, contextuais, presentes.

Tolerar - ensina a raiz latina tollo - denota o esforço que fazemos sobre nós mesmos. Ninguém tolera o que é bom. Toleramos ou dizemos tolerar ou, ainda, pregamos que se tolere o que é mau, o que é ruim. Nos primórdios do pensamento ocidental, com Sto. Agostinho (1952), a tolerantia tem uma aceção coletiva: a do autocontrole da cristandade ao lidar com os maus, com as pessoas imorais, com os infiéis. A da caridade, que ajuda a suportar os que são um peso para a humanidade. A tolerância com a fraude académica discente, no entanto, parece se explicar de outra maneira: ela decorreria da prudência, da indulgência e da conveniência.

A vertente prudencial da tolerância deriva do direito canónico, que pela volta do primeiro milénio já sustentava que o mal não deve ser punido quando é secular, o que não significava aprová-lo (Ecclesia non approbat, sed permittit). Permitia-se o mal pela impossibilidade de eliminá-lo - como no caso da prostituição - ou em favor do ordenamento do convívio com grupos irredutíveis à lei canónica, como o dos judeus (Bjeczvy, 1995). O paralelo com a tolerância prudencial se aplica ao caso da fraude académica na medida em que a seguir-se todas as normas burocráticas, a se aferir tudo que é copiado na época do Google e da Wikipédia, a se discutir a fragilidade dos fundamentos e dos argumentos, e, principalmente, a se alardear a baldia tolice que distingue a maior parte da produção académica da atualidade, a instituição universitária se veria em sérias dificuldades.

A tolerância passou a significar a indulgência entre os credos após as guerras religiosas dos séculos XVI e xVII. Os argumentos a seu favor são de ordem moral, de ordem eidética, de ordem utilitária, de ordem legal, de ordem política e de ordem epistemológica. O argumento moral de Erasmo (1999) e de Locke (1964), diz que a perseguição é violência e que a violência se opõe à civilidade e à caridade. $\mathrm{O}$ argumento da essência diz que se concordamos política 
ou religiosamente no fundamental (credo minimum), a razão da intolerância desaparece. Voltaire (1829) argumentou que a tolerância se opõe ao fanatismo. Que era preciso esmagar o fanatismo cristão (écraser l'Infâme) fundado na superstição e na ignorância, em nome do interesse público. Dizia ele que devemos nos tolerar porque todos somos falíveis. O argumento legalista diz que a intolerância é um mal porque produz a coalizão dos dissidentes, e porque a repressão aos hereges é contraproducente porque cria mártires. O argumento político diz que a intolerância reforça a convicção dos que discordam e gera a revolta (Espinosa, 1982). O argumento epistemológico diz que devemos ser tolerantes porque ninguém pode pretender ter a razão absoluta, só Deus. Esta longa enumeração ensina que qualquer que seja o fundamento da tolerância indulgente com a fraude dos estudantes, ela tem uma raiz clara: a instituição e os docentes toleram porque são falíveis, porque não há uma das fraudes listadas no início deste texto que não seja praticada pela academia e pelos docentes. O número de artigos retirados, as contestações não respondidas às pesquisas, o dinheiro gasto com iniciativas sem justificativa, estão aí para quem quiser ver com isenção. Criou-se até uma figura estranha, a despublicação (sic), uma tentativa de manter a aparência de seriedade científica, procedimento em que a ênfase recai nos termos "tentativa" e "aparência".

A terceira vertente explicativa da tolerância com a fraude académica discente é coeva. Herbert Marcuse (1970) sustentou que a tolerância com os dissidentes na sociedade liberal tem o propósito de servir não para a emancipação dos grupos e das pessoas explorados, mas para adormecer os impulsos libertários. Com isso, torna-se repressiva, embora sob a aparência de libertadora. Marcuse, que informou intelectualmente os movimentos rebeldes da segunda metade do século passado, trouxe à luz a ideia de que a autodeterminação é viciada pelas instituições. De que a ideologia da tolerância favorece a conservação do status quo arcaico. Uma ideia que leva a perguntar 
se a tolerância com a fraude entre os universitários não seria uma estratégia conservadora.

\subsection{Discussão}

As categorias e os argumentos que expus postulam a fraude discente como consequência de um duplo desajuste: entre a universidade e o ideal académico, entre a instituição e o mundo que a circunda. Parece-me que a universidade de há muito abandonou a figura platónica da Academia. Buscou o anedótico e o burocrático. Ao renunciar ao ideal da profundidade e da propagação, a universidade se fez barroca. Parou no tempo e transformou-se em sua própria caricatura. O fenómeno da fraude pode não ser inteiramente negativo. A sua problematização abre a oportunidade de a academia meditar seu destino, justificar-se ante o mundo, exumar seu espírito.

Um eventual esforço de regeneração do ideal académico não se dará sem perdas de energia, de comodidades e de status. Mas não vejo outra forma de desencorajar a fraude universitária discente que não seja a recuperação do espírito platónico. Não cabe propor que a academia retroaja à Academia. É tolo tentar adequar o mundo às instituições. Mas não é tolo aspirar que a academia volte a viver para suprir a dificuldade de todos e de cada um em descobrir a verdade por si mesmo.

Fraudar o arbitrariamente estabelecido, mesmo quando expressão de uma inevitabilidade ou opção discordante, não pode deixar de produzir efeitos, de ter resposta. Mas esta resposta, não deve ser um revide. A resposta coercitiva pode ter base legal, mas não tem, necessariamente, fundamento na ética, e com certeza é estéril. Reprimir e castigar o fraudador não me parece justo ou produtivo. Há que considerar que a fraude não pode ser atribuível exclusivamente àquele que frauda e que a punição contém e dissimula, mas nada cria ou transforma. 
A explicação dada por São Tomás de Aquino (2006) para a punição infligida às crianças não batizadas é que se trata de um castigo que não é aflitivo, mas privativo: o da perpétua privação da presença de Deus. No meio académico, a punição límbica é imposta àqueles que por malícia, instinto, descaso ou ingenuidade fraudam o paradigma estabelecido pelas divindades universitárias. Condenados ao Limbo do olvido, do insulamento e da exclusão, os fraudadores recebem o castigo privativo do convívio, do acesso e da certificação. Um castigo fadado à banalidade formalista. Para os jovens do nosso tempo a privação académica não é desagradável. É fora da academia que a vida está acontecendo. Depois, está-se em boa companhia. Como no Limbo, está-se com os incontaminados, com aqueles que São Tomás falhou em justificar porque deveriam ser punidos.

\subsection{Referências bibliográficas}

Agamben, G. (2013), A comunidade que vem. Belo Horizonte: Autêntica. Aristóteles (1952), The works of Aristotle. Chicago: William Benton.

Bergson, H. (1986), L'évolution créatrice. Paris: Presses Universitaires de France.

Bjeczvy, I. (1995), “Tolerantia”, a medieval concept. Journal of the History of Ideas, 58( 3), julho.

Cornford, F. M. (1952), Principiun sapientiae: the origins of Greek philosophical thought. Cambridge: Cambridge University Press.

Cumming, I. (2000), Helvetius: His life and place in the history of educational thought. Londres: Routledge.

Deleuze, G. (1990), Michel Foucault, filósofo. Barcelona: Gedisa.

Erasmo, D. (1999), Lettre à Carondelet ( 5 de janeiro de 1523). In Julie Saada-Gendron, La tolérance. Paris: Flammarion.

Espinosa, B. (1982), Ética. Madrid: Aguilar.

Howson, C. (2000), Hume's problem: induction and the justification of belief. Oxford: University of Oxford Press. 
Isaac, C. (2011), Forbes 400: The Self-Made Billionaire Entrepreneurs Who Said No To College. Forbes / Leadership. Obtido em 19 de março de 2014 em http:// www.forbes.com/sites/worldviews/2011/09/23/forbes-400-the-self-made-billionaire-entrepreneurs-who-said-no-to-college/

Jaeger, W. (1979), Paideia: a formação do homem grego. São Paulo: Livraria Martins Fontes Ltda.

Locke, J. (1964), Carta a respeito da tolerância. São Paulo: IBRASA.

Mandeville, B. de (1997), The fable of bees and other writings. Indiana: Hackett Publishing Company, Inc.

Marcuse, H. (1970), Tolerância repressiva. In Robert Paul Wolff; Barrington Moore Jr. e Herbert Marcuse, Critica da tolerância pura. Rio de Janeiro: Zahar.

Mills, D. G. (2003), Lying/Perjury vs. Fraud/Deceit - Dissident Voice. Obtido em 12 de março de 2014 em http://www.dissidentvoice.org/Articles7/Mills_BushFraud-Deceit.htm

Nietzsche, F. (1990), A genealogia da moral. Lisboa: Guimarães Editores.

Nietzsche, F. (2010), Além do bem e do mal. São Paulo: Centauro.

Platão (1981), Obras completas. Preâmbulos e notas por María Araujo, Francisco García Yague, Luis Gil, José Antonio Minguez, María Rico, Antonio Rodríguez Huescar e Francisco de P. Samarach. Introdução a Platão por José Antonio Miguez. Madrid: Aguilar.

Queirós, E. [1893], (1966), Positivismo e idealismo. Notas contemporâneas - Obras completas. Porto: Lello e Irmão.

Rampell, C. (2013), America's Biggest Entrepreneurs: High School Dropouts. Economix. Obtido em 19 de março de 2014 em http://economix.blogs.nytimes. com/2013/04/19/americas-biggest-entrepreneurs-high-school-dropouts/?_r=0

Rousseau, J. J. (1973), Discours sur l'origine et les fondements de l'inégalité parmi les hommes. Paris: Aubier Montaigne.

Santo Agostinho (1952), On Christian doctrine. Chicago: Enciclopaedia Britannica, Inc. São Tomás de Aquino (2006), Suma teológica: os sacramentos. São Paulo: Loyola, vol. 9. Sokal, A. D. (1996), Transgressing the Boundaries: Towards a Transformative Hermeneutics of Quantum Gravity. Social Text, 46/47 (primaver/verão). Duke University Press, pp. 217-252. 
Voltaire, F. M. A. (1829), Oeuvres complètes de Voltaire (com notas, prefácio, advertências, observações históricas e literárias. Paris: Armand-Aubree, Éditeur.

Wells, J. T. (1997), Occupational fraud and abuse. Londres: Obsidian Publishing Co. 


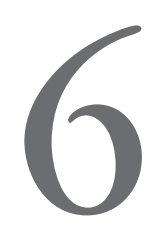

\title{
A ÉTICA COMO OBJETO DE ENSINO
}

\author{
Luís Adriano Oliveira \\ Prof. do Departamento de Engenharia Mecânica \\ da Universidade de Coimbra (DEMUC)
}

José Luís Afonso

Provedor do Estudante da Universidade

de Coimbra e Prof. do DEMUC

bttp://dx.doi.org/10.14195/978-989-26-1123-5_6 
(Página deixada propositadamente em branco.) 
Deve a ética ser ensinada ao longo da formação curricular de um estudante de nível superior, universitário ou politécnico? A questão não é consensual e merece ponderada reflexão.

Dependendo das circunstâncias em apreço - logísticas, curriculares, ou outras - o ensino de ética a estudantes de nível universitário ou politécnico pode assumir diversos formatos: disciplina específica inserida na estrutura curricular; parte do programa de unidade letiva mais abrangente; workshop; conferência ou videoconferência; seminário; curso; colóquio; ou simples debate, eventualmente promovido por estrutura representativa dos próprios estudantes.

É, hoje, unanimemente reconhecida a imperiosa necessidade de respeitar e fazer respeitar princípios de conduta ética na vivência corrente da sociedade, em geral, e, por inerência, na prática quotidiana do ensino superior, objeto central do presente seminário. Menos consensual será, entretanto, a necessidade - ou sequer a conveniência - de conferir estatuto autónomo ao ensino de ética a estudantes de nível superior.

Nomeadamente, vozes críticas do ensino explícito de ética a jovens universitários avançam argumentos como (Elliott e Stern, 1997; Oliveira, 2013): trata-se de estudantes adultos, de formação moral e ética já consolidada, pouco recetivos, portanto, a alterações comportamentais significativas; o ensino de ética tem base essencialmente genérica e teórica, enquanto a prática quotidiana suscita problemas específicos, que requerem soluções concretas; normatização excessiva retira espaço à criatividade; a conduta ética no quotidiano universitário é apenas uma particularização da conduta ética na vida, sendo que proscrever atitudes eticamente condenáveis decorre do simples 
exercício de bom senso; o tempo gasto na estruturação do que se entende por boas práticas será mais rentável se diretamente investido na concretização dessas boas práticas.

Argumentos defensáveis, sem dúvida! Porém, a simples análise dos dois estudos de caso a seguir apresentados, e de tantos outros que a realidade vivida no ensino superior poderá trazer a este debate, convidam a breve exercício de reflexão acrescida.

I) - Estudo de caso relatado por Oliveira (2013). "Em outubro de 2008, integrei um júri de dissertação de mestrado em engenharia mecânica. A dissertação tinha por tema a ventilação natural em espaços de trabalho e o candidato, José Tomás ${ }^{20}$, apresentara um trabalho que o júri considerou, de forma unânime, de muito boa qualidade. Durante as provas, porém, o examinador externo, Prof. Manuel Campos, comentou: "Ao ler, pela primeira vez, a página 34 da sua dissertação, fui invadido por uma estranha sensação de déjà $v u$. Mais tarde, voltei a ela e fez-se luz: essa página reproduz fielmente, embora sem qualquer sinal de citação, texto da minha própria tese de doutoramento. Tem consciência da gravidade de um ato de plágio como este?" Resposta do candidato: "Admito esse facto. Confesso que reproduzi o texto porque me pareceu muito oportuno e que me esqueci de referir a fonte. Na verdade, não fazia ideia de que essa omissão fosse assim tão grave!"

Pessoalmente, acreditei na sinceridade da resposta. De facto, nessa altura a sensibilização dos alunos para a questão ética limitava-se essencialmente a comunicar-lhes que não deviam "copiar" nos exames!

20 À exceção dos dois coautores do presente texto, todos os nomes aqui referidos são, naturalmente, fictícios. 
José Tomás foi significativamente penalizado, tendo obtido o grau de Mestre com a classificação mínima. Hoje, de forma mais ou menos estruturada, existe já a preocupação de incutir princípios éticos ao longo da formação curricular. Alertados que estão os alunos para a problemática da usurpação de autoria, José Tomás teria, no mínimo, sido reprovado."

II) - Desde longa data, a cadeira de Mecânica dos Fluidos, ministrada no Departamento de Engenharia Mecânica da Universidade de Coimbra (DEMUC), vem adotando a prática de disponibilizar aos alunos, via Internet, proposta de resolução de todas as questões formuladas em provas escritas (testes, frequências, exames finais...) destinadas a avaliação curricular. A resolução avançada não é, obviamente, a única possível: trata-se apenas de um exemplo de resposta que, na ótica do docente, mereceria cotação máxima.

Em avaliação recente, o exame de época de recurso continha uma pergunta já formulada oito anos atrás. Enquanto resposta a essa questão, um aluno reproduziu textualmente a proposta de resolução que tinha sido, à época, disponibilizada.

Como deverá o docente reagir, perante tal situação?

A dedicação de um espaço próprio ao ensino de ética teria, porventura, evitado a ocorrência das duas falhas comportamentais acima relatadas.

Não se preconiza, aqui, a leitura acrítica de "compêndios" sobre o assunto, ou de textos normativos mais ou menos diretamente aplicáveis. Pelo contrário, em nosso entender, o estudo de ética deverá centrar-se essencialmente na discussão de casos práticos, envolvendo mesmo a ocorrência de dilemas éticos. Nesse espaço dialogal, 
dinamizado e assistido pelo docente, e fundamentado na legislação aplicável (leis gerais, estatutos, regulamentos, normas, declarações de ética, códigos de conduta, textos de apoio...), cada aluno terá oportunidade de testemunhar o seu ponto de vista, expor as suas dúvidas ou perplexidades, sugerir formas de detetar, prevenir ou evitar a ocorrência de condutas eticamente questionáveis ou mesmo censuráveis, refletir sobre a melhor forma de reagir face ao não respeito das boas práticas.

Com efeito, nem sempre é óbvia, para um jovem universitário, a distinção entre: (i) - moral, ética, deontologia; (ii) - erro honesto, erro por negligência ou por incompetência, erro fraudulento [fabricação, falsificação, plágio (FFP)]; (iii) - conflitos de interesse, conflitos de compromisso; (iv) - boas práticas, práticas questionáveis, práticas censuráveis; (v) - denúncia interna, denúncia externa; (vi) - repreensão oral, repreensão escrita, sanção, processo disciplinar.

Como refere Oliveira (2013), as instituições federais americanas National Institutes of Health (NIH) e Alcohol, Drug Abuse, and Mental Health Administration (ADAMHA) condicionam a concessão de financiamento a programas de formação em biomedicina à garantia de que tais programas incluam instrução sobre "conduta responsável na investigação" (NAS, NAE E IOM, 1992). A crescente ocorrência de situações de natureza conflituosa decorrente de falhas éticas, que se vem registando na última década, no seio da comunidade universitária, permite antever que tal exigência de formação ética tenda a estender-se à escala planetária.

Em Portugal, nomeadamente, é notório o esforço de regulamentação que diversas entidades de ensino superior vêm desenvolvendo, com particular incidência para a elaboração de declarações de ética e de códigos de conduta.

Refletir sobre tais textos normativos, em espaço próprio dedicado ao ensino de ética, não tem por finalidade desafiar ou sequer questionar a formação humana de jovens adultos que são os estudantes 
do ensino superior. Pelo contrário, trata-se, sim, de refletir sobre a forma mais adequada de colocar essa formação ao serviço da sua vocação universitária, responsável, ao mesmo tempo que se procura promover a consciencialização para os problemas - de consequências não raro graves - que podem advir de práticas eticamente questionáveis ou mesmo censuráveis. Mais do que encarar os textos normativos como "receituários" a seguir de forma acrítica ou a aplicar cegamente, procura interiorizar-se o respetivo conteúdo, aplicando-o a casos concretos, notando que um mesmo problema de natureza ética pode conduzir a diversas soluções igualmente respeitáveis, fruto do enquadramento geográfico, científico, cultural, financeiro ou, simplesmente, temporal.

Usando a terminologia proposta por Figueiredo (2009), trata-se, em essência, de utilizar a ética normativa na promoção do que realmente se procura alcançar: a ética da responsabilidade.

A experiência que os autores deste texto vêm acumulando sobre o ensino de ética na formação universitária é, de resto, eloquente: de um modo geral, os estudantes reagem de forma claramente encorajadora, testemunhando confiança acrescida para encarar o seu quotidiano universitário, e maior sentido de responsabilidade para gerir a vertente ética inerente a esse mesmo quotidiano. Testemunho igualmente gratificante é partilhado por diversos autores/professores, nomeadamente Elliott e Stern (1997), Figueiredo (2009), ou Stewart (2011).

Pode, mesmo, sugerir-se a inclusão de matéria afim em espaço letivo opcional do último ano curricular do ensino secundário. Naturalmente adaptado às condições concretas vigentes, tal ensino de ética seria uma primeira sensibilização para o futuro percurso universitário ou politécnico, ou ainda, não sendo esse o caso, para o seguimento responsável de qualquer via profissionalizante.

Em conclusão, se o ensino de ética for encarado como espaço de diálogo centrado em questões concretas ilustrativas, onde ética normativa se conjuga com ética da responsabilidade, com claro 
predomínio para a segunda, então o espaço letivo dedicado ao ensino de ética assume a dimensão de investimento estratégico, e a resposta à questão inicialmente formulada é claramente afirmativa.

\subsection{Referências Bibliográficas:}

Elliott, D. e Stern, J. E. (Orgs.) (1997), Research Ethics: A Reader. Hanover, NH: University Press of New England for the Institute for the Study of Applied and Professional Ethics at Dartmouth College.

Figueiredo, A. D. (2009), Uma experiência do ensino da ética a futuros profissionais de tecnologias da informação. Signo y Pensamiento, 28(55), pp. 152-162.

NAS, NAE, IOM - NATIONAL ACADEMY OF SCIENCES, NATIONAL ACADEMY OF ENGINEERING, INSTITUTE OF MEDICINE (1992), Responsible Science: Ensuring the Integrity of the Research Process (Volume I). Washington, D.C.: National Academy Press

Oliveira, L. A. (2013), Ética em Investigação Científica. Lisboa: Lidel - Edições Técnicas, Lda.

Stewart, C. N. Jr. (2011), Research Etbics for Scientists: a Companion for Students. West Sussex, UK e Hoboken, NJ: Wiley-Blackwell - John Wiley \& Sons, Ltd. 


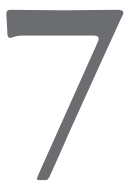

\title{
A ÉTICA NA DOCÊNCIA UNIVERSITÁRIA: ENTRE O IDEAL E O REAL
}

\author{
Maria Teresa Estrela \\ Unidade de I e D, em Educação e Formação \\ Instituto de Educação, Universidade de Lisboa
}

bttp://dx.doi.org/10.14195/978-989-26-1123-5_7 
(Página deixada propositadamente em branco.) 


\subsection{Introdução}

Este texto não pretende ser mais do que um olhar sobre a ética docente no atual contexto de mudança das instituições do ensino superior, de alguém que, tendo cessado uma longa carreira no ensino universitário, sempre trabalhou e investigou no campo da educação e na formação de professores. Por isso, partimos de uma perspetiva da universidade como uma instituição de formação ao mais alto nível, de produção e divulgação de saber, inserida numa sociedade que a mantém e com a qual se relaciona e para o progresso da qual deve contribuir. Pondo o acento tónico na instituição e não na organização que também é, queremos realçar os ideais, fins e valores partilhados que constituem sistemas de referência e lhe conferem uma identidade moral própria - a sua "alma mater" - que se vai construindo e reconfigurando ao longo do tempo em interação com a sociedade envolvente, a sua cultura, as suas instituições, necessidades e aspirações. Ora, as universidades atuais partilham de vários tipos de problemas que afetam as sociedades, atravessadas por crises de toda a ordem, que são também crises de ética e de valores. Crises acentuadas pela globalização, pelos "poderes sem rosto" que condicionam a economia e as políticas, incluindo as de educação, pelas restrições financeiras, pelas faltas de ética no trabalho, pela corrupção, pela competitividade sem regras, pelas transformações introduzidas pelas tecnologias da informação originadoras de progresso mas também de novas necessidades sociais. As universidades são pressionadas para grandes mudanças, algumas das quais interpelam a sua ética e exigem mudança dos papéis tradicionais de alunos e professores, 
multiplicando tensões, antinomias e dilemas a que se vêm juntar as que são próprias das instituições e do processo educativo.

Sendo instituições de formação, compartilhamos a conceção, hoje comummente aceite, da educação/formação como práticas sociais, posteriormente teorizadas, que visam influenciar e facilitar o desenvolvimento do ser humano, em convívio com outros seres humanos, em toda a sua possível plenitude e ao longo da sua vida. Por isso, formação e ética estão indissoluvelmente ligadas e assumem um caráter essencialmente relacional. Numa linguagem freireana, toda a formação é uma procura intencional, de um ser marcado pela incompletude, de ser e mais ser, visando a autonomia e a emancipação da pessoa. E se os estudantes são jovens adultos ou adultos menos jovens, nem por isso a sua formação ética deixa de envolver fenómenos de extrema complexidade, com os quais o professor tem de lidar, pois são atravessados por antinomias presentes nas teorias e práticas onde se entrecruzam fenómenos de caráter biopsicológico, político, ético, social, económico, cultural, pedagógico. São fenómenos localizados espacialmente e historicamente situados num presente efémero, em continuidade ou em rutura com o passado próximo e tentando preparar um futuro de cada vez mais difícil previsão. Educação/formação remetem para mundividências expressas ou ocultas, ligadas a ideologias de vária ordem, com a sua ética e os seus valores potencialmente conflituais e que procuram ganhar credibilidade argumentativa apoiando-se na filosofia, numa ciência em particular ou num conjunto daquelas ciências que permitem a inteligibilidade da vida do ser humano em convívio com outros seres humanos. Embora a educação para uma cidadania esclarecida seja uma das finalidades que as instituições do ensino superior hoje assumem, não tomaremos a cidadania como um objeto de reflexão neste texto, pois consideramos que ela só ganha sentido em relação a uma ética que a enquadra. Relembra Formosinho (2007, p. 253) que nas raízes gregas da educação moral como educação do caráter está 
a sua ligação à polis que lhe confere substancialidade. "Porquanto se a cidadania é a condição jurídica do indivíduo, mediante a qual o Estado reconhece e garante um conjunto de direitos, a sua configuração substantiva vai exigir por parte dos indivíduos a adesão a valores e padrões normativos que possibilite a assunção de deveres para com a comunidade". Padrões e normas que exigem uma fundamentação ética anterior que lhe confira coerência.

Fazemos estas considerações prévias para que fique claro que, para falarmos da ética docente no ensino superior (esclarecemos que por comodidade de escrita e por melhor conhecimento do campo falaremos geralmente em universidades), nos situamos no campo da educação e da sua articulação com a ética e em relação com contextos que a determinam ou, pelo menos, influenciam. Teríamos naturalmente outro olhar se tivéssemos outra formação académica e experiência profissional, ou se partíssemos de uma ética profissional em geral, que hoje alguns querem transformar num objeto de estudo, originando uma nova área do conhecimento com influência na sociologia das profissões (Mathenge, 2012).

Em todos os tempos houve reflexões sobre a universidade e a ética das suas missões, muitas delas por vultos eminentes da cultura mundial. Embora valorizando esses contributos, os nossos propósitos são bem mais modestos e pragmáticos. Visam apenas tentar recolher aspetos do pensamento e agir ético dos docentes, dados através de pesquisas de caráter empírico e completados, por vezes, pela nossa experiência de vida universitária. Tentámos, na medida do possível, pôr entre parênteses as nossas convicções. No entanto, porque elas podem influenciar, mesmo que inconscientemente, as nossas interpretações esclareceremos apenas dois pontos que nos parecem mais pertinentes.

Evitando imitar os cronistas medievais que começavam a História do seu tempo pelo Génesis, não iremos debater conceitos e correntes de educação/formação, nem tão pouco ir aos primórdios do 
pensamento grego, embora muitas das suas conquistas estejam ainda presentes no pensamento ético da modernidade e da pós-modernidade. Abriremos uma exceção para referirmos Aristóteles, cuja influência, independentemente das posições que cada um possa tomar, se mantém especialmente viva pela sua teorização da ação teleológica. $\mathrm{Na}$ "Ética a Nicómaco", a ação transforma-se em ação moral quando orientada para um bem supremo que é a felicidade, que não se confunde com um hedonismo primário, pois só se atinge pela razão que orienta a prática da virtude. A ética da virtude está bem presente em pensadores contemporâneos da ética que têm influenciado algum discurso sobre a ética da educação. Talvez um dos mais conhecidos em alguns meios docentes seja A. MacIntyre (1986), considerado um neoaristotélico, para quem cada comunidade pode encontrar um modelo de pessoa e padrões de excelência, mediações comparáveis a virtudes, capazes de assegurar o agir ético de uma comunidade concreta. Em vários documentos internacionais que falam da ética, encontramos traços da ética das virtudes ligada a valores de base que se deseja que o ensino superior promova, como honestidade, confiança, imparcialidade, respeito, responsabilidade, prestação de contas (accountability) (Declaração de Bucareste, 2004).

Contudo, - sem pretendermos fugir a uma tomada de posição pessoal, e não podendo apresentar uma teoria ética original integradora dos vários contributos que fomos recebendo ao longo de anos, processo de difícil construção dada a enorme diversidade de correntes e autores que se cruzam no pensamento ético nos nossos dias, sejam elas de natureza filosófica, sociológica, psicológica, a que se acrescenta ainda o novo contributo das neurociências - esclarecemos que consideramos a ontologia como a base da ética enquanto reflexão sobre os princípios orientadores da conduta humana; posição que se alicerça na filosofia, mas que não exclui contributos da psicologia, sociologia e pedagogia. Não obstante, reconhecemos o caráter inovador de alguns argumentos que sustentam a primazia 
da ética, assentes em fundamentações tão diferentes como as que podem ser exemplificadas por Levinas (1982/2007) e por Bauman (1997), que encontra uma fundamentação intrínseca da moral, vendo na responsabilidade moral o ato autoconstitutivo da vida social. Segundo Levinas é o primado da relação com o outro que está na origem de tudo e da humanidade, posição que pode transformar a relação pedagógica, conferindo-lhe outra inteligibilidade e outro tipo de responsabilidade. Como defende Afonso (2007, p.1), na reflexão que faz sobre o contributo de Levinas a propósito da relação pedagógica, há no seu pensamento, um fascínio

\footnotetext{
"que julgo tenha a ver com uma nova noção de humanidade: o ser humano é ser para o outro, não há humanidade sem relação ética, sem escuta e abertura àquilo que o rosto do outro tem para me dizer e pedir. Assim, a ética deixa de ser um conjunto de princípios morais a determinar a ação ou um conjunto de virtudes a mediar a obtenção de fins bons, para se tornar um acontecimento, um encontro quotidiano: eu e o outro face a face. Falar de ética é falar desse encontro, do modo como o eu responde ao outro que o interpela".
}

Não é, no entanto, através desta ética do rosto que pensamos a relação pedagógica, embora estejamos de acordo com o caráter relacional da ética e a responsabilidade que ele implica que encontramos noutros autores como Ricoeur (1990) e se cruza com o caráter fundamentalmente relacional da pedagogia.

Por outro lado, embora reconheçamos o caráter cultural e contextual das normas morais e de alguns valores sociais enquanto aplicação de princípios éticos a situações particulares, consideramos que não se pode, sem cair em alguma contradição, defender um relativismo axiológico radical, como acontece com alguns pensadores pós-modernistas que rejeitam o caráter universal dos princípios éticos, mas 
se batem simultaneamente pela defesa de princípios básicos como o da dignidade humana. A nosso ver, o imperativo categórico kantiano que considera a pessoa humana sempre como um fim em si e jamais como um meio é aquele que melhor define e defende essa dignidade. $\mathrm{E}$, nos tempos atuais, em que a vida do planeta se mostra ameaçada pela insensatez e ganância humana, parece-nos que o imperativo formulado por Jonas (1998), sobre o dever de agir para preservar a vida das gerações vindouras no planeta, é um belo complemento do imperativo Kantiano.

Veja-se, portanto, este texto como um intertexto onde se cruzam textos ou fragmentos de textos oriundos de várias áreas disciplinares que se foram acumulando, apagando ou reconstruindo ao longo do tempo, com as perdas e ganhos que isso implica.

Os nossos objetivos são, como se disse, pragmáticos: levantar alguns problemas éticos que se colocam aos professores de ensino superior valorizando principalmente as representações que eles têm desses problemas; averiguar que respostas encontramos na investigação empírica sobre o pensamento e o agir ético dos docentes e que interrogações delas decorrem.

\subsection{Desafios éticos postos aos docentes}

\subsubsection{Os contextos de mudança}

"In the light of the constant reconfigurations of globalization, higher education institutions are now expected to assume an even more prominent role as exponents of modern, democratic social values such as freedom of expression and association, equality of access, responsibility toward stakeholders, and the rule law (...). Yet with the emergence of the knowledge society, higher education research institutions are more 
directly implicated in economic and social life, and, in turn, more affected by it."

(...) "While most current debates on European higher education focus on topics such as institutional and management, students flows, quality assurance, and trade in educational services, academic values have been sidelined and basics principle regarding what is, and is not mere academic verbiage, as inattention to fraud, nepotism, proper governance and corruption in higher education will indeterminate its status and role in a democratic society" (...)

Sadlak and Ratajczak, 2004, p. 433.

A citação que destacámos põe sinteticamente em evidência os contextos de mudança em que a ética do ensino superior deve ser equacionada e a menor atenção que a ética e os valores que ela fundamenta têm merecido. Com efeito, basta pesquisar as bases de dados referentes à educação e às ciências sociais para se notar um claro contraste entre a crescente produção de reflexões e estudos empíricos que se têm ocupado de variados aspetos da vida das instituições de ensino superior e aqueles que tomam como foco a ética dessas instituições e dos seus atores.

$\mathrm{E}$, no entanto, pensamos que a ética deveria ocupar um lugar central nesses estudos, por várias razões. Entre elas, e em primeiro lugar, porque se trata de instituições que, como a designação de língua inglesa "higher education" bem explicita, são, como já dissemos, instituições de educação e formação ao mais alto nível. Dirigidas para o desenvolvimento de seres humanos e orientadas por princípios, fins e valores que circunscrevem as missões que lhes são definidas pelas leis gerais dos países onde se inserem, e onde elas próprias se definem dentro da autonomia que lhes é concedida, assumem, por isso, um caráter eminentemente ético. Em segundo lugar, porque devido às transformações ocorridas nos últimos decénios nas universidades em função de valores 
economicistas, as preocupações de eficácia e eficiência tornaram-se prevalecentes, acentuando a desigual competição das universidades a nível nacional e internacional. Essas preocupações desafiam a ética profissional dos docentes, pois ameaçam subverter a ética do ensino ao subordinar-lhes os valores de equidade e de solicitude em relação a todos os que participam no processo formativo (López, 2005). Por outro lado, a visão economicista levou à quase marketização do ensino, investigação e serviços (Marginson, 2007), pondo em causa muitos valores que impuseram as universidades como referências intelectuais e morais. Criam-se assim fraturas entre os docentes, ocasionadas por mundividências diferentes e, por vezes, inconciliáveis, gerando posições e atitudes não isentas de maniqueísmo; mas também se colocam em jogo interesses de difícil harmonização quando não são subordinados a preocupações éticas de bem geral, sobretudo quando as universidades são vistas como organizações técnicas. Por outro lado, a massificação do ensino superior transformou as instituições numa "large scale enterprise" (Szostek, 2004). O apelo à inclusão de novos públicos, feito em nome da democraticidade e da justiça, por vezes, mal oculta as necessidades de sobrevivência ligadas ao sistema de financiamento, com implicações éticas diretas no trabalho dos docentes e podendo eventualmente desvirtuar os processos de recrutamento que resultariam numa fraude em relação aos alunos. $\mathrm{O}$ acolhimento de novos públicos requereria necessariamente uma nova pedagogia e uma nova ética menos racionalista e formalista do que aquela que tem vigorado tradicionalmente; exigiria uma relação pedagógica de proximidade, orientada para uma ética relacional de cuidado pelo outro (que pode encontrar fundamentações teóricas diversas), que o grande número de alunos por turma não ajuda a implementar, ainda que os professores saibam e queiram implementá-la. Nova pedagogia que o Acordo de Bolonha, aliás, estipula, mas dificilmente exequível pela falta de recursos humanos e materiais, que fazem com que as tutorias em muitas escolas só existam no papel ou nem isso. 
Assim, não admira que as universidades sejam atravessadas por novas tensões decorrentes de visões mais humanistas ou mais economicistas, o que também pode explicar a ausência de debate ético envolvendo os professores das instituições. Diz Andreoti Oliveira (2012), na curta apresentação que faz da rede WERA, que se propõe estudar a ética global das instituições de ensino superior, que na literatura sobre a internacionalização se detetam duas influências principais: uma orientada para a competitividade; outra, humanista, orientada para a promoção da qualidade de vida humana das comunidades mais desfavorecidas. Considera, no entanto, que na literatura mais recente, através de conceitos como os de "cidadania global", se pretende conciliar as duas tendências, dando como exemplo, entre outros, os trabalhos de Jefferess (de 2008), de Koo (de 2011) e de Andreoti et al. (de 2010).

Há, portanto, uma ética universitária que abrange e responsabiliza a instituição no seu todo enquanto pessoa jurídica e moral que é; e responsabiliza moralmente, em particular, as pessoas que integram os vários corpos que a constituem. Por isso, mereceria constituir-se em objeto de estudos empíricos sobre o modo como aqueles que a integram estão a respeitar os princípios éticos que as suas missões implicam e como estão ou não empenhados no seu compromisso social, pondo o seu saber pedagógico e científico ao serviço do progresso e justiça social.

A ética universitária apresenta-se, pois, como uma realidade complexa, multifacetada, exigindo abordagens multidisciplinares, mas que pode sempre ser tomada num duplo ponto de vista: a ética, enquanto reflexão e fundamentação dos princípios em que assenta a moral e que se situa a montante desta última, determinando os fins e valores subjacentes às missões e envolvendo todos os que participam na realização dessas missões, prescrevendo funções e papéis àqueles que a integram; o exercício ético dessas funções e papéis nas situações do dia a dia. 
Se pode haver insuficiências ou incoerências na definição dos princípios, é no exercício dessas funções que se manifesta o caráter ético da ação e das suas consequências. Talvez seja por isso que só se fala de ética universitária quando alguma coisa corre notoriamente mal a nível social, quer se trate da gigantesca fraude que provocou a atual crise financeira, quer se trate dos abusos ou da falta de ética dos jornalistas dos diferentes meios de comunicação que se abatem como abutres sobre a desgraça alheia; ou, ainda, de acontecimentos infelizes, como a recente tragédia do Meco que vitimou 6 estudantes, que, com razão ou sem ela, levantou o problema da violência das praxes académicas e pôs em causa a responsabilidade das universidades e professores. Então questiona-se a formação ética e moral que as universidades dão aos seus estudantes e os professores tomam consciência de que, absorvidos pela sua investigação, se esquecem que são docentes e educadores (Sousa, 2011), como exprimiu recentemente um professor universitário num jornal diário, a propósito dessa tragédia.

\section{3. Ética estudantil e ética docente}

Se a ética universitária pode ser estudada e questionada a todos os níveis, é a nível da ética dos alunos e da ética dos professores que ela precisa de ser particularmente estudada, pois alunos e professores são os principais atores que conferem sentido às instituições de ensino superior. Interagindo no âmbito das situações pedagógicas, como seres de relação que são, formam-se e são formados por essa interação, pelo contacto humano que ela proporciona e pela experiência de situações que vivem em conjunto e contribuem para a construção das suas identidades profissionais, se considerarmos a identidade como um processo contínuo de construção pessoal e profissional em interação com o meio (Dubar, 1997). 
Por um lado, a ética estudantil, expressa no seu discurso e nos seus comportamentos académicos, pode constituir uma referência indireta ao modo como a universidade e os professores estão ou não a contribuir para a aprendizagem ética dos estudantes; por outro lado, dá-nos uma ideia do tipo de problemas que os professores têm de enfrentar e da sua preparação para os enfrentar. O que parece justificar que a investigação sobre a ética dos estudantes, a sua formação e as suas quebras de comportamento ético tenha conhecido um surto de desenvolvimento neste século que a investigação sobre a ética docente parece não ter conhecido, tanto quanto pudemos averiguar. Porque as falhas éticas dos estudantes enquanto estudantes desafiam também a ética docente, faremos sucintamente algumas considerações que não pretendem desculpabilizar quem as comete, mas tentar compreender os contextos de comportamentos menos éticos.

\subsubsection{A ética dos estudantes}

Os jovens que frequentam o ensino superior neste novo século foram já educados numa sociedade cheia de desequilíbrios sociais; uma sociedade globalizada, individualista, consumista e ferozmente competitiva, que apela ao sucesso fácil, despreza os perdedores e cultiva a supremacia do ter sobre o ser; os jovens vivem por vezes em famílias que, por razões várias, frequentemente opostas, os deixaram entregues a si próprios e expostos a modelos individualistas e hedonistas que os multimédia veiculam na "sociedade espetáculo", onde não raramente reina a boçalidade e se perdem noções de respeito em relação a si mesmo e aos outros, de sentido de limites e de civismo; fizeram parte da sua escolaridade numa escola em crise de valores, em que os professores viram degradar a sua imagem social, perderam parte da sua autoridade e muitas vezes foram afetados por um relativismo axiológico demolidor, que a cultura pós-moderna 
alimentou e que os faz hesitar nos valores a transmitir; têm, em geral, facilidade de acesso rápido a toda a espécie de informação e a um certo ambiente de desresponsabilização na partilha de informações, que parece imperar nos meios virtuais de informação e comunicação, não propiciando o respeito pelos outros e pelos direitos de autor. A pedagogia escolar com a moda da "pesquisa", desde os mais tenros anos, se não for devidamente controlada, poderá contribuir, para esse desrespeito, criando hábitos difíceis de corrigir.

Não admira, por isso, que os professores de ensino superior comecem a enfrentar problemas de indisciplina na sala de aula, de má educação, de bullying e de falta de civismo dentro dos espaços escolares, de aumento de violência e o primarismo das praxes; além de enfrentarem problemas de fraude que não se reduzem ao "copianço" (falsos trabalhadores-estudantes, atestados médicos falsos para justificar ausências prolongadas ou faltas aos exames, entre outras). Por outro lado, em sociedades em que o sucesso económico e político têm por vezes uma sustentação fraudulenta, e em sociedades, como a nossa, em que, além disso, parece existir uma desresponsabilização de quem a comete, a fraude académica surge como um tipo de fraude socialmente considerado menor. Aparece-nos então como uma faceta do espírito de "desenrascanço" (perdoe-se-nos o plebeísmo), de um "fazer pela vida" em que os fins legitimam os meios e que, apesar da censura daqueles que se sentem lesados, chega a causar alguma admiração dos pares que gostariam de fazer o mesmo, mas não ousam fazê-lo.

Compreende-se que a fraude nos exames em trabalhos sujeitos a avaliação assuma especial importância, dado pôr em causa o bom nome da instituição ao comprometer a credibilidade do ensino, da investigação e da formação ética que proporciona. Subjacente a qualquer tipo de fraude há sempre a violação de princípios e valores social e institucionalmente considerados, como verdade, honestidade, responsabilidade, confiança, respeito pelo outro, concorrência leal... 
Não nos iremos deter no plágio, fenómeno antigo, mas que ganhou visibilidade e que as novas tecnologias ajudam a fomentar, cuja análise é tarefa de outros mais habilitados do que nós. Permitir-nos-emos apenas sublinhar três aspetos:

a) a importância já considerável da investigação empírica que incide sobretudo nas perspetivas de estudantes sobre a diferente gravidade de tipos de fraude, causas que lhes atribuem, permitindo estudar variáveis académicas e sociais que influenciam essas perspetivas. Em relação a Portugal, veja-se o ponto da situação e os trabalhos de Almeida, Gama e Peixoto (2011);

b) algumas medidas preventivas e corretivas tomadas pelas instituições merecem-nos algumas considerações, na medida em que poderão indiciar posições mais punitivas ou mais formativas, embora todas invistam na informação aos estudantes e na clarificação das regras do jogo. Apresentamos como exemplo dados que recolhemos ocasionalmente sobre as Universidades de Bath e Nothingham. Em Bath, os estudantes de licenciatura e de pós-graduação de qualquer curso são obrigados à frequência de um curso on line em que são tratadas as diferentes modalidades de fraude e a sua gravidade intrínseca; os regulamentos da Universidade estabelecem minuciosamente os tipos de punição a que cada tipo de fraude fica sujeito, e que podem ir da dedução da cotação de uma resposta copiada à anulação do teste, passando pela reprovação na disciplina e até mesmo à perda do grau e expulsão da Universidade; só os menos graves dependem da decisão do professor. Preocupada em salvaguardar sobretudo a ética da investigação, neste caso na área da iniciação à prática de investigação, em Nothingham (Winder et al. 2007) são elaborados guias de orientação e 
de riscos a evitar na investigação desenvolvida pelos estudantes, estabelecendo esses guias protocolos de princípios que, após discussão, os estudantes e os seus supervisores deverão assinar.

Interrogamo-nos até que ponto a ênfase e o detalhe das punições será a via mais formativa e não contribuirá para uma moralidade heterónoma dos alunos, não desenvolvendo a sensibilidade ética aos princípios. Parece-nos que poderá igualmente dificultar o desenvolvimento moral dos próprios professores, limitando-lhes a liberdade do seu juízo ético-profissional e do exercício pleno da sua autonomia moral na decisão sobre a penalidade a aplicar; por outro lado, a minúcia de um regulamento essencialmente punitivo parece deixar a montante a complexa função da formação ética geral dos estudantes que a universidade enquanto instituição educativa deveria salvaguardar. O mesmo se poderia dizer de alguns códigos ditos de boas práticas.

Até que ponto esses códigos não poderiam ter origem nas associações de estudantes e serem discutidos e aprovados pelas autoridades académicas? Não sabemos se é realista, mas certamente seria um processo formativo para os estudantes.

c) Os professores e o plágio: se os estudantes são os principais autores do plágio, não são os únicos. De vez em quando chegam-nos notícias, de que os meios de comunicação se fazem eco, de plágios cometidos por professores ou candidatos a professores, sendo às vezes figuras públicas. Mas outros há, talvez a maioria, que circunscrevem a suas atividades aos meios académicos e parece-nos que o fenómeno não é tão excecional quanto se poderia julgar. A pressão na carreira tem levado alguns a desculpabilizarem-se do recurso a meios menos ortodoxos. Há também indícios de uma tolerância aparentemente incompreensível da parte 
de alguns professores a comportamentos fraudulentos dos estudantes, sobretudo em trabalhos académicos que não os exames. A razão dessa tolerância suscita algumas interrogações: porque não estão dispostos aos incómodos que uma intervenção inevitavelmente causa? Por uma questão de compaixão talvez mal compreendida? Porque se sentem relativamente responsáveis pela falta de supervisão adequada e atempada que deveriam ter exercido? Talvez porque eles próprios a praticaram?

Sabemos que a atitude dos professores perante a fraude estudantil começa a ser investigada, mas não tivemos acesso a resultados. Seja qual for a causa dessa complacência, não contribui para uma tomada de consciência da falta de ética nem fortalece o sentido de responsabilidade (Gutiérrez e Barrón, 2011).

Levanta-se a questão das relações mútuas entre ética docente e discente e seria interessante investigar como é que a ética dos alunos influencia também a do professor e como ele se forma ao formar outros. Por isso, pareceu-nos relevante recolher alguma informação sobre a ética estudantil.

\subsubsection{Outras temáticas de investigação sobre a ética dos estudantes}

Para intervir adequadamente, é preciso conhecer a realidade onde se pretende intervir. Não sendo a prevenção da fraude o único aspeto a merecer a atenção das universidades, justifica-se que a investigação sobre formação ética dos estudantes se tenha debruçado sobre outros aspetos, alguns dos quais referiremos sucintamente.

Trata-se, em geral, de investigação de caráter disciplinar ou multidisciplinar, sobre aspetos diferentes da ética estudantil. O que 
mostra que alguns investigadores, geralmente professores, estão preocupados com a formação ética dos seus estudantes. Para além dos trabalhos sobre o plágio que avultam quando consultamos bases de dados, outros problemas têm atraído a atenção dos investigadores. Um dos principais diz respeito à formação proporcionada pela universidade na área ético-deontológica relacionada com a futura profissão e a avaliação dessa formação, de que damos apenas alguns exemplos. São sobretudo as áreas do ensino e de profissões técnicas relacionadas com a economia as que suscitam mais investigação. De entre as estratégias utilizadas, talvez as mais comuns sejam a análise de situações, questionários e dilemas éticos (Oliveira, Thomé e Andrade, 2011); Murphy, E. Pinnegar e S. Pinnegar (2011); Valentini e Tsukamoto (2011); Wongchantra et al. (2008); Walker (2011); Boon (2011). Aparece também uma minoria de trabalhos de formação ética mais geral, ligada ao currículo ou à utilização de determinadas metodologias ou técnicas de ensino, como ambientes virtuais de aprendizagem (Loureiro et al.,2011; Rodrigues, Matos, e Barni, 2011; Githui, 2011; Jamil, Shah e Tariq, 2013; Oliveira, 2012). Outros trabalhos preocupam-se com o desenvolvimento moral dos alunos e/ ou com os seus valores (Alakurt, Bardakçi e Keser (2012). Outra preocupação emergente é relativa à formação ética para a investigação e que vai para além da prevenção do plágio, pois contempla outros princípios a respeitar quando a investigação se faz sobre seres humanos (Ells, 2011; Romanowski e Martins, 2011). As preocupações parecem incidir mais sobre os estudantes de pós-graduação do que sobre os próprios professores. Embora haja estudos quantitativos, é a dimensão ética dos estudos qualitativos que é salientada, assim como é constatada a influência dos comités éticos de pesquisa na aquisição pelos estudantes de princípios como consentimento livre e esclarecido, respeito pela dignidade, autonomia, vulnerabilidade da pessoa, a ponderação de riscos e benefícios e a relevância social da pesquisa (Romanowski e Martins, 2011). 
$\mathrm{O}$ que nos parece novo em relação a pesquisas anteriores é o caráter internacional da preocupação pela formação ético-deontológica dos estudantes enquanto objeto de investigação, pois os textos recolhidos relatam trabalhos empíricos oriundos de universidades de países tão diferentes como Espanha, USA, Reino Unido, Nigéria, Turquia, China (Hong Kong), México, Portugal e Tailândia.

\section{4. Ética docente}

Sendo que os professores são o principal garante da ética universitária, espera-se deles o exemplo ligado à vivência de uma ética profissional que deveria ser debatida e aceite pelo coletivo dos professores, independentemente da existência ou não de um código escrito. Por isso algumas instituições têm investido em códigos de boas práticas que regulamentam os procedimentos que os docentes devem seguir na sua atuação docente, em especial na avaliação dos estudantes. Também entre nós, algumas instituições têm investido em manuais de boas práticas, como o Instituto Superior Técnico de Lisboa e departamentos de Química da Universidade de Aveiro, o que pressupõe a existência de algum debate prévio.

Sem esse debate coletivo, intra e interinstitucional, a ética docente no ensino superior torna-se um assunto do foro puramente pessoal, de que se fala pouco dentro das instituições (a "dimensão perdida"; Macfarlane, 2004), embora noutras tenha havido um debate ativo, envolvendo toda a instituição (Moore, 2006)

Documentos provenientes de organismos internacionais, sobretudo da UNESCO (1998), têm promovido a reflexão sobre a nova universidade e a ética que ela postula, reforçando as suas dimensões formativas e de compromisso social. Compete-lhes formar eticamente os seus estudantes, tornando-os cidadãos ativos na construção de um mundo mais humano e justo. Essas recomendações refletiram-se em 
documentos sobre o ensino superior europeu. Destacamos a Magna Carta assinada pelos Reitores de Universidades Europeias (1988), que influenciou, sem dúvida, os princípios expressos nos estatutos que muitas universidades foram levadas a reformular na sequência do Acordo de Bolonha. No entanto, carecemos de informação sobre o que os professores pensam da ética ligada ao desempenho das suas novas funções, que dilemas elas lhes ocasionam, como aderem ou não à função de educadores éticos que lhes é recomendada e como se sentem preparados para a exercer.

Os trabalhos de natureza empírica sobre ética docente não têm grande visibilidade na consulta a bases de dados a que procedemos recentemente, nem nas revistas de educação e afins dos últimos três anos, embora se note um aumento de reflexões de autoria individual ou em coautoria. O xIX colóquio da AFIRSE (bilingue), realizado em Lisboa, em 2010, sobre "Deontologia, Ética e Valores. Realidade e Utopia"/ "Déontologie, Ethique et Valeurs en Education. Realité et Utopie”, confirma essa falta de visibilidade. Dada a desproporção entre o número de comunicações e o número considerável de participantes, esse colóquio mostrou que a investigação no domínio da ética educacional não é muito cultivada. Apenas $12 \%$ das comunicações apresentadas tinham como objeto de estudo a ética no ensino superior, notando-se todavia algum equilíbrio entre o número de comunicações de caráter teórico e empírico. O tema que registou maior frequência de comunicações incindiu na ética dos alunos. Apesar de haver participantes de países como o Brasil, Espanha, França, Canadá, México e Portugal, foram pouco numerosos os trabalhos empíricos referentes à ética docente no ensino superior, procedendo na quase totalidade do Brasil.

Da análise do conjunto das comunicações sobre o ensino superior a que procedemos posteriormente (Estrela e Afonso, 2012), infere-se que as investigações não decorrem de uma linha de pesquisa existente e que são os problemas percecionados nas suas instituições 
que levam à procura de quadros conceptuais, geralmente multidisciplinares, e/ou de dados empíricos que permitam compreender, contextualizar e apresentar pistas de solução. De uma forma geral, os professores sentem as suas instituições e o seu trabalho ameaçados por políticas e valores economicistas de caráter neoliberal, sentindo uma grande pressão que se exerce sobretudo através dos sistemas de avaliação do ensino e da investigação e é causadora de desgaste físico e emocional (Baldi e Barreto, 2011). Apesar disso, outros sentem-se satisfeitos com a docência, fortalecendo-se na ética que os leva a procurar a dimensão universal dos valores dos grupos e culturas (Valentini e Tsukamoto, 2011). Como forma de resistência à orientação economicista da universidade, defendem os valores de autonomia, liberdade, seriedade, justiça, igualdade de oportunidades, respeito pela diversidade ou formas de pedagogia que superem uma centração excessiva nas matérias disciplinares (Ramos, 2011).

Dos trabalhos empíricos recenseados sobre ética docente sobressaem os que encontrámos em autores de língua espanhola, em especial mexicanos, onde se constata a existência de linhas de investigação. Trata-se de estudos que, por vezes, envolvem uma dimensão comparativa: entre universidades mexicanas (Hirsch, 2006); entre universidades mexicanas e espanholas (Sales et al., 2007; entre cursos da mesma universidade (Hirsch, 2009); entre professores e alunos que apresentam grande similitude na valorização das competências éticas (Hirsch e Pérez Castro) O projeto estadual sobre saberes produzidos nas universidades originou o "Proyecto Interuniversitario sobre ética profesional" que incrementou as investigações neste campo. Parte de uma extensa revisão da literatura de vária natureza publicada sobre o tema, abrangendo vários aspetos entre eles a ética docente, a formação de professores e relação com a ética profissional.

Apesar das particularidades dos contextos em que os estudos são realizados, parece-nos que nos textos em língua espanhola se 
verifica a semelhança de problemas que as universidades enfrentam num mundo globalizado e transfronteiriço.

Assim, nota-se: algum desconforto ético e emocional entre os professores que se traduz em tensões e dilemas entre as exigências institucionais a que estão sujeitos e o seu sentido de compromisso social e dever ético; a defesa de valores como responsabilidade, compromisso, honestidade, honradez, respeito pela integridade e honra de outrem; a perceção de discrepância entre os discursos sobre as missões das universidades e as mudanças efetivas que são sentidas como impostas do exterior; o aparecimento de novos problemas éticos ligados as tutorias (Chávez e Benavides, 2011); a falta de unanimidade sobre o papel dos professores como formadores morais, argumento essencialmente apoiado na idade dos alunos, pessoas autónomas e já portadoras de valores éticos e principalmente sobre a necessidade de formação ética dos professores (Sales e al, 2007); a pouca ou relativa eficácia sobre a formação dispensada na universidade em relação à ética estudantil (Hirsch e Pérez-Castro, 2013) - não sendo os resultados consonantes com os da investigação proveniente de outros países, como o Brasil, por exemplo. Concluem os últimos autores que estão a ganhar força no campo da investigação: dilemas, condutas não éticas, ética da investigação e do desenvolvimento tecnológico, análise de valores e crenças específicas e aspetos sociais.

\subsubsection{A ética docente no ensino superior em Portugal, essa des- conbecida}

Enquanto os estudos empíricos sobre o pensamento ético dos docentes de ensino não superior começam a ter alguma visibilidade no nosso país, tal não acontece em relação aos docentes de ensino superior. Com efeito, a consulta feita a bases de dados nacionais e às listas de dissertações de mestrado e teses de doutoramento das 
diversas universidades parece confirmar a ausência de investigação empírica sobre o tema, onde só encontrámos os produzidos pela nossa equipa. Uma explicação possível é o facto das universidades portuguesas que se viram envolvidas num processo que não pediram e que exigiu mudança das suas estruturas, organização, funcionamento e filosofia de ensino, terem concentrado a sua atenção no planeamento curricular dos novos cursos - que em algumas instituições não foi totalmente pacífico - e nas novas exigências de avaliação que pesam sobre eles, deixando de lado o debate ético que poderia ser demorado e inconclusivo. Segundo o testemunho de 14 professores de várias instituições, entrevistados em 2008/09, num estudo de que adiante falaremos, tal debate não existiu nas suas escolas ou, se existiu, não tiveram dele conhecimento.

Falar de ética docente no ensino superior no nosso país torna-se então um exercício de êxito duvidoso, pois faltam-nos fontes diversificadas e fidedignas que nos permitam sustentar o nosso discurso. Corremos o risco, dificilmente evitável, de cair numa retórica bem-intencionada, não destituída de algum moralismo, que projeta mais as nossas crenças pessoais e os nossos desejos do que projeta uma realidade multifacetada que cada um perceciona e vive à sua maneira.

\subsubsection{Alguns dados baseados na experiência}

Tentando minimizar esse risco mas não o anulando, procurámos reunir indícios vários que, embora dispersos e não diretamente comparáveis, nos permitissem encontrar algumas pistas sobre o que pensam os professores portugueses em relação à sua ética profissional. $\mathrm{Na}$ falta de outros dados, não excluímos a nossa experiência de longos anos na universidade com a qual ainda mantemos alguns contactos.

Quem trabalha nas instituições de ensino superior há longo tempo sabe que, em geral, não se fala nem se debate a ética subjacente 
a certas decisões, dando razão àqueles que, como atrás referimos, consideram a ética universitária “a dimensão perdida”. Parece-nos que seria preferível falarmos da dimensão oculta que haverá todo o interesse em desocultar. Assim, essas pessoas podem testemunhar apenas o que observaram nas mais diversas circunstâncias e cuja perceção depende naturalmente dos quadros de referência e da sensibilidade que levam a apreciar eticamente um comportamento em situação. Da ética docente tem-se mais um conhecimento subjetivo das quebras de princípios que, segundo quem as avalia, deveriam orientar a conduta profissional, do que propriamente dos princípios e valores professados pelos docentes e transpostos diariamente para a sua prática profissional, por vezes com algum sofrimento e conflito entre razão e emoção. Talvez sobressaiam justamente por serem menos comuns. Apesar disso, certamente que todos também foram testemunhas de uma dedicação total à profissão e à instituição, de sentido de compromisso social, de defesa corajosa de princípios, de solidariedade, cooperação e de resistência a pressões. A vida interna das instituições universitárias parece desmentir a crença, ainda corrente, de que a cultura forma o caráter revelado no dia a dia através dos comportamentos e atitudes profissionais dos docentes. Uma elevada ética profissional apoiada na sua formação cultural pô-los-ia acima das pequenas fraquezas do cidadão comum. Mas como a universidade não é (e pensamos que ainda bem, pois se o fosse afastar-se-ia da sociedade) uma corporação de santos e aprendizes de santos, por vezes causam surpresa alguns atos ou palavras, mais vezes dirigidos a colegas do que a alunos, reveladores de alguma arbitrariedade, prepotência, parcialidade, vaidade, ódios de estimação, aceitação da lisonja, complacência perante a fraude, defesa de corporativismo institucional que se revela, por exemplo, em alguns editais de concursos que parecem redigidos pensando num possível candidato, na preferência pelos "candidatos da casa" ou na multiplicação de cursos criados por interesses dos professores, defraudando 
os dos estudantes. No entanto, não tivemos conhecimento direto (o que não significa que nunca tenham ocorrido) de algumas quebras éticas mais graves de professores de que os alunos são vítimas ou corresponsáveis, que a literatura internacional aponta, como assédio sexual, extorsão de dinheiro aos estudantes (Oghuvbu e Okpilike, 2012); nepotismo, governança incorreta, desvios nos processos de creditação, inflação de efetivos, favoritismo político no recrutamento de pessoal fraude nos exames (Poisson, 2011); abuso de confiança, nepotismo, conflito de interesses, violência, (Hirsch, 2010). Muitos destes atos inserem-se já no domínio da corrupção, definida por Hallak e Poisson (citados por Poisson, 2011), como a utilização sistemática de cargos públicos para fins privados, comprometendo o acesso, a qualidade e a equidade da educação e podendo suscitar sanções, não só académicas como penais.

\subsubsection{A ética docente vista através das queixas dos alunos}

A ética docente, vista pelo ângulo dos alunos, tal como nos é permitido avaliar pela consulta aleatória de atas dos Conselhos Pedagógicos de diferentes instituições divulgadas na Internet, não apontam muito no sentido do agir ético dos professores. As queixas dos alunos referem-se mais a problemas de organização e funcionamento dos cursos do que a atos individuais que configurem graves transgressões docentes. São, contudo, referidas algumas transgressões deontológicas, sobretudo a propósito da avaliação e algumas inconsistências normativas, sendo os docentes os primeiros a transgredir normas e procedimentos estabelecidos pela instituição e às vezes por eles próprios. Infere-se que a ética docente pode ser afetada por atos de arbitrariedade, intransigência, parcialidade e, mais frequentemente, pelo não cumprimento do dever de feedback, demorando a entrega dos testes para além do estabelecido e fazendo com que os alunos 
vão a exame final sem conhecimento dos resultados da avaliação contínua. As tomadas de posição dos professores presentes nas reuniões poderão, quando muito, indiciar princípios éticos diferentes, postos em jogo na apreciação das queixas, eventualmente orientados por uma ética racionalista do dever, que se traduz numa aplicação rígida das normas estabelecidas sem atender às circunstâncias ou por uma ética contextualizada do cuidado mais atento às necessidades específicas dos alunos.

A leitura de alguns Relatórios, divulgados na Internet, do Provedor do Estudante, entidade que tem sobretudo uma função de mediação e aconselhamento, dá-nos, quando muito, elementos sobre o tipo e a frequência das queixas, mas, como é compreensível dado o dever de confidencialidade e de proteção da privacidade, não nos dá elementos sobre o seu teor. Esses relatórios confirmam que, para além da avaliação que coloca problemas de justiça e equidade, as queixas, em geral, incidem sobre aspetos que não estão diretamente relacionados com a atividade docente; a exceção que encontrámos (Universidade de Aveiro) refere queixas relativas à relação pedagógica, mas não é referido o seu conteúdo. Note-se, porém, que a nossa pesquisa não foi exaustiva por concluirmos ser de reduzido interesse para o nosso objetivo.

\subsubsection{Os Estatutos das Universidades Públicas}

Relembramos que a necessidade de reformulação dos Estatutos das instituições surge como consequência imediata da uniformização pretendida para a criação de um espaço europeu do ensino superior. Por ignorar tradições e condicionalismos nacionais e locais, foi vista como uma imposição vinda de cima que muitos docentes aplaudiram e outros criticaram e rejeitaram, o que aconteceu em muitos outros países. A elaboração dos Estatutos seria, em princípio, uma 
oportunidade de reafirmação e de adaptação de princípios e valores tradicionais às novas exigências postas pelo Acordo de Bolonha.

Como critério de seleção dos Estatutos, retivemos para análise dos princípios éticos assumidos explicitamente, os Estatutos das quatro maiores universidades e uma das de menor dimensão situada no interior do país. Embora as comissões estatutárias tenham representantes de outros setores, pensamos que a influência dos docentes terá sido preponderante na sua elaboração. Nessa medida, os Estatutos poderiam refletir a ética dos professores como uma das dimensões de afirmação pública do seu profissionalismo. Com efeito, é a eles que compete em grande parte serem o garante da ética da sua universidade. Por outro lado, os Estatutos gerais servem de quadro inspirador e limitador dos Estatutos das várias escolas, onde é suposto ser maior a participação dos docentes na sua elaboração e aprovação. Contudo, não somos tão ingénuas que não saibamos que em muitos casos os representantes dos docentes não se representam senão a si próprios, deixando os seus colegas e as suas escolas à margem do debate que provavelmente existiu no interior das comissões. Por outro lado, não é crível que os defensores de uma universidade humboldtiana mais elitista e mais ciosa da sua ética se tenham convertido, de um dia para o outro e sem reserva interior, em apologistas de uma universidade mais pragmática e aberta à sociedade, mas também aos valores economicistas que o Acordo de Bolonha, apesar da retórica progressista, também veicula. Até que ponto esses professores estarão disponíveis para uma conversão das suas convicções abrindo-se a uma visão mais utilitarista e a uma ética relacional mais contextualizada, capaz de acolher e proporcionar sucesso aos estudantes que tiveram percursos de vida diferentes daqueles que seguem percursos tradicionais? É uma questão que fica em aberto.

Os Estatutos examinados diferem muito na sua organização interna e no grau de explicitação de princípios que aparecem ligados à apresentação da instituição, às suas missões ou aos seus objetivos e 
antecedem a definição de órgãos, funções e princípios do funcionamento. Se isso não facilita a comparação, permite contudo constatar algumas preocupações éticas dessas instituições.

Nos Estatutos da Universidade de Coimbra (2008), a Universidade assume como matriz identitária os princípios proclamados na Magna Carta dos Reitores Europeus, onde é claro o espírito de uma ética humanista assente em princípios de defesa da dignidade humana, de liberdade, tolerância, responsabilidade, compromisso social, prevalência do interesse geral... Por isso, a Universidade propõe-se promover o desenvolvimento económico e social, a justiça social e a cidadania esclarecida e responsável, com base no conhecimento construído dentro de princípios de rigor, verdade e humildade científica.

Idêntico desejo de intervenção social está expresso nos Estatutos da Universidade do Minho (2008), que se propõe contribuir para a construção de um modelo de sociedade baseada em princípios humanistas e incluindo a formação ética no âmbito das formações que a Universidade deve proporcionar (cultural, científica, artística, cidadã). O respeito pela dignidade humana é um dos princípios básicos da Universidade que defende igualmente a prevalência do interesse geral e os princípios democráticos de participação, pluralismo e liberdade de opinião. Os Estatutos da Universidade do Porto (2009), além de outras responsabilidades, como a de cooperação entre os povos, atribuem-lhe a de formação global - cultural, científica, técnica, artística, cívica e ética e tem um artigo intitulado "Valores". Entre alguns mais comuns, como a transparência, a qualidade, a ausência de discriminação, contém outros valores e princípios que, julgamos, só essa Universidade enuncia e que parecem revelar preocupações de uma educação inclusiva, assente numa ética do cuidado: a preocupação de assegurar a realização pessoal a todos os que a integram e a eliminação de obstáculos que constituam desvantagem para os portadores de deficiência.

Os Estatutos da nova Universidade de Lisboa, resultante da fusão da antiga Universidade de Lisboa e da Universidade Técnica de Lisboa, 
são um pouco mais parcos em termos de enunciação de princípios e valores de caráter ético. Se a primazia é concedida à investigação científica e inovação, dentro de um espírito de valorização económica e social do conhecimento como fazendo parte da sua matriz identitária, não estão ausentes princípios comuns a outras universidades, como a liberdade intelectual, respeito pela ética e pela pessoa. Como nota digna de menção, sobretudo no atual contexto de avaliação da investigação, está explícito o princípio de defesa da língua portuguesa.

A Universidade de Trás os Montes e Alto Douro afirma o seu propósito de contribuir para o progresso da região onde se insere e para o progresso do país, através da realização das suas missões de ensino, investigação e serviços à comunidade. Na perspetiva de uma cultura humanista, valoriza a formação contínua como elemento de desenvolvimento profissional e pessoal.

Em síntese, com matizes não negligenciáveis na enunciação das suas missões e na hierarquia e ênfase dada a cada uma delas, há em comum aos diferentes Estatutos a abertura à sociedade, o sentido de compromisso ético-social e de contributo para o progresso do país através da investigação e inovação. No caso das universidades mais recentes, dá-se especial relevo à intervenção nas regiões onde se inserem. E numa época em que alguns valores da investigação, que reputamos básicos num investigador, começam a ser desrespeitados, parece-nos particularmente pertinente que a Universidade de Coimbra venha lembrar o rigor, a verdade e a humildade científica que dá solidez ao conhecimento científico.

Seria interessante conhecermos até que ponto os professores das universidades conhecem os princípios éticos definidos nos seus Estatutos, os fazem seus e os transferem para a sua prática de ensino, investigação e serviços à comunidade. Sem essa interiorização pode acontecer que não resistam aos constrangimentos do real. A História da Educação em Portugal é fértil em generosas ideias reformadoras que são traídas na sua aplicação, pois carecem da implementação 
das condições materiais e humanas que as tornariam possíveis. E receamos que a História se repita.

\subsubsection{Um estudo exploratório e qualitativo sobre a ética docente no ensino superior}

Enquanto que os estudos empíricos sobre a ética docente no ensino não superior começam a ter alguma visibilidade, o mesmo não acontece relativamente ao ensino superior. Uma pesquisa em bases de dados e a consulta da lista de dissertações de mestrado e teses de doutoramento nas bibliotecas universitárias revelou-se improdutiva. Por isso, resolvemos apresentar algumas conclusões de um pequeno estudo de caráter exploratório que se enquadrava num projeto mais amplo ${ }^{21}$.

Apresentaremos de modo muito sucinto algumas conclusões da análise das entrevistas realizadas, uma vez que aspetos diferentes do estudo originaram algumas publicações. As conclusões que tirámos são apenas válidas para este grupo de professores, não se pretendendo qualquer generalização.

Como seria expectável, os dados revelam diferentes sensibilidades éticas que se manifestam nos seguintes aspetos e estão, em geral, em consonância com posições (e o tipo de argumentos nelas utilizados) detetadas a nível internacional: i) recusa, por uma minoria, do papel de formação ética dos estudantes em função do seu nível

\footnotetext{
${ }^{21}$ O projeto "Pensamento e formação ético-deontológica de docentes", financiado pela FCT, envolveu docentes de todos os graus de ensino. As entrevistas visavam a construção de um questionário. Constatando-se, após as entrevistas no ensino superior, que não havia condições para o concretizarmos, o projeto acabou por ser desenvolvido apenas no ensino não superior. Entrevistas semi-estruturadas foram feitas a 14 docentes do ensino universitário e politécnico públicos, de duas cidades (Lisboa e Bragança) e ligados a várias áreas do conhecimento: ciências sociais, filosofia, saúde, engenharia e ciências exatas. Os protocolos obtidos foram objeto de uma análise de conteúdo categorial.
} 
etário, redução desse papel à formação deontológica relativa à futura profissão, por outra minoria, e aceitação pela maioria; ii) atitudes de rejeição minoritárias, adesão e adesão condicional ("que não caia na endoutrinação", "que não seja dada por professores de filosofia"...) relativamente à necessidade de formação ética dos professores e, também, à eventual elaboração de um código deontológico; iii) conceções diferentes do bem do aluno visto em termos instrumentais e relativos por uns, em termos absolutos por outros (preparação para a vida, felicidade, realização humana; justiça como igualdade orientada por uma ética universalista do dever / ética contextualizada do cuidado, orientada por princípios de caring). Distinguindo os professores, na sua maioria, a ética, como reflexão sobre a conduta humana, da moral, enquanto campo de aplicação da ética a situações concretas, a ética surge como uma construção pessoal assente em várias fontes de socialização, numa cultura de caráter geral e na experiência profissional; e raramente na influência de pensadores da ética. Daí uma grande sobreposição entre ética pessoal e profissional, existindo essa distinção para uma minoria. Verificou-se uma consonância total em relação aos valores orientadores da investigação que os seus alunos deverão também adotar: rigor, objetividade, verdade e honestidade. Quanto ao ensino, se há valores que todos os entrevistados mencionam - respeito, autonomia, justiça — já outros acrescentam valores como liberdade, bem, competência, dignidade. Aos alunos exige-se honestidade, responsabilidade e respeito, a que outros docentes acrescentam justiça, bem, liberdade.

Não podemos esquecer que o discurso dos entrevistados se vai construindo na interação com o entrevistador e traduz um espaço momentâneo de racionalização de um tema complexo que interpela a razão mas não deixa de fora a emoção. Se as respostas do tópico do guião tivessem sido dadas por escrito, é natural que os níveis de reflexividade e de fundamentação do discurso tivessem sido diferentes. Assim, os discursos revelam algumas hesitações e, uma vez por 
outra, contradições. Contudo, apesar da diversidade das posições assumidas, podem encontrar-se algumas linhas de coerência.

\footnotetext{
"Por exemplo: uma linha de coerência entre conceções universalistas e inatistas da ética e a negação da necessidade de formação ética de professores e estudantes do ensino superior, por um lado, as conceções contextuais e adquiridas da ética e a aceitação da necessidade de formação de professores e alunos, por outro; entre uma visão do profissionalismo mais orientada para as competências científicas e técnicas, e outra que, sem desprezar a competência científica e técnica, é orientada para a formação humana em geral, o que poderá denotar diferentes configurações de identidade profissional determinadas pela interação do eu com diferentes meios de trabalho e com as áreas de ensino. Coexistem, portanto, diferentes posturas éticas (num universo de muitas outras possíveis), umas baseadas no racionalismo da modernidade, outras que se aproximam, em graus diferentes, de algumas posições pós-modernistas sobre a ética e os valores" (Estrela, 2010, p.10).
}

Os dados analisados levaram-nos a considerar a hipótese da influência do género no discurso dos nossos entrevistados, apesar da investigação ter encontrado resultados pouco consistentes nos estudos empíricos (Acker, 1995-1996; Sabbe e Aelterman, 2007). Por um lado, a sustentar teoricamente a hipótese, há os trabalhos feministas, representados principalmente por Gilligan (1997) e Noddings (2001) que afirmam a existência de uma orientação ética diferente entre homens e mulheres, caracterizando-se estas por uma orientação para o cuidado (caring). Criticam Kohlberg pelo racionalismo e formalismo da teorização das etapas de desenvolvimento ético ou moral assente em populações masculinas. Tratando-se de estudantes 
do ensino superior, jovem adultos ou adultos que aparentam não requerer tanto dos seus professores essa orientação para o caring, pareceu-nos interessante aprofundar essa hipótese nos nossos dados. Uma análise de conteúdo pelo programa informático AQUAD, realizada por um membro da equipa (Alves, 2009), sobre 5 entrevistas femininas e 5 masculinas incidindo apenas nas categorias de discurso que nos pareciam diferentes, (a justiça no ensino e o bem do aluno), mostrou, através do coeficiente Tanimoto, que os discursos eram dissemelhantes. É claro que se trata ainda de uma hipótese que carece de confirmação em estudos futuros.

Outra hipótese que emergiu do estudo, mas que não foi aprofundada, refere-se a eventuais diferenças entre os professores do ensino universitário e do politécnico. As diferenças mais aparentes dizem respeito à valorização da ciência que começa por se revelar na sua forma de apresentação profissional ("investigador e professor" e "professor e investigador"), mas também parecem existir sobretudo na conceção do bem do aluno e de justiça no ensino. Bem e justiça são as chaves do pensamento ético e são fins consensuais da formação universitária, mas consenso apenas sobre os termos, pois os conteúdos que contêm geram os maiores desacordos por serem aqueles onde ética e política mais se imbricam. Por todas as razões, as instituições de ensino superior carecem de um debate sobre a ética que lhes é proposta pelas instâncias internacionais e que as transformações das universidades exigem.

\subsection{Conclusão - Entre ideal e real, os professores, a sua ética e os seus dilemas}

Não há dúvida que as universidades mudaram para dar resposta aos desafios que a sociedade do conhecimento lhes coloca, redefinindo as suas missões e os seus papéis, com repercussão direta no trabalho 
dos docentes/investigadores e na ética que o orienta. Aumentaram as expectativas públicas quanto ao investimento do seu conhecimento na prossecução do progresso e justiça social. Princípios humanistas proclamam ainda a sua independência em relação aos poderes políticos e económicos (Magna Carta), intenção piedosa que choca com uma realidade impiedosa. Por isso, a Declaração de Budapeste (2004) incentiva a um novo equilíbrio entre a Universidade como instituição de serviço público e uma organização empresarial. Equilíbrio que exige às instituições e aos docentes escolhas éticas, principalmente difíceis quando está em jogo a sobrevivência de umas e de outros.

Os professores poderão não perder tempo a pensar nos problemas que hoje se levantam à ética da universidade e à ética docente, conformando-se com uma situação que não foi criada por eles. Fugindo aos problemas, poderão continuar a funcionar de forma individualista e rotineira, centrados na sua investigação e nos aspetos científicos e técnicos das matérias que lecionam, empenhando-se na competição como defesa da sua carreira, feita por vezes a qualquer preço. Embora não seja essa a postura crítica que se espera dos universitários, dela não só lhes não advirá qualquer prejuízo, como até é provável que tenham mais êxito do que aqueles que se debatem com dilemas éticos e se implicam em ultrapassar os condicionalismos que pesam sobre eles. Por exemplo, esforçando-se por atenuar a despersonalização da relação pedagógica que a massificação propicia ou criando métodos de ensino baseados na diferenciação pedagógica possível, especialmente necessários para atender às necessidades dos estudantes com percursos académicos não tradicionais.

Num momento em que já se fala da ética dos robots, os professores não podem deixar de se interrogarem, nas suas instituições, sobre a ética que salvaguarde o bem social e sem se deixarem transformar em funcionários acríticos e subservientes. Por isso, terminamos, pondo ou repetindo algumas questões que se levantam cada vez com maior acuidade. 
Até que ponto a resiliência dos princípios éticos se manterá perante a intensificação do trabalho, as pressões para a excelência, as turmas numerosas que impedem o uso de metodologias de ensino mais formativas, a heterogeneidade dos alunos nas universidades, todas elas a exigirem uma postura e atuação ética dos docentes que para muitos não fazia parte das suas práticas? Como é que se posicionam os docentes entre a equidade e a eficácia? A excelência para todos em termos de processo - levando cada um à máxima perfeição possível, em acordo com o pensamento Kantiano sobre a educação - ou a excelência como produto, só para alguns - que é aquela que permite o rating desejado? Até que ponto a investigação que sempre foi privilegiada na avaliação dos docentes, com os novos critérios bibliométricos de avaliação e a internacionalização e os múltiplos projetos ligados a redes, não levará os docentes a deixar para segundo plano o ensino, o acompanhamento da investigação e a atenção à formação humana dos estudantes com os quais contactam entre duas partidas de avião? Experimentam ou não dilemas e como se sentem quando têm que escolher entre a pertinência científica e social dos projetos e a possibilidade de eles serem confortavelmente subsidiados? E como podem os docentes, principalmente nas instituições que explicitaram publicamente a defesa da língua portuguesa, sem protestos veementes, pactuar com o critério de avaliação que leva a desvalorizar publicações na língua nacional, a esvaziar algumas boas revistas que ainda temos e a diminuir o impacto possível que os resultados de investigação poderiam ter na transformação da realidade que constituiu o seu campo de estudo?

São respostas que só os estudos empíricos sobre as posturas éticas dos docentes perante uma realidade que muitos sentem constrangedora da sua liberdade e dos seus princípios éticos poderão dar resposta, contribuindo ao mesmo tempo para que as instituições se conheçam a si próprias, reorientem as suas metas e melhor definam a sua identidade. 


\subsection{Referências bibliográficas}

Acker, S. (1995-1996), Gender and Teachers' Work. Review of Research in Education, 21, pp. 99-162.

Afonso, M. R. (2007), A responsabilidade por outrem na ética de Levinas. Obtido em 4 de maio de 2014 em http://www.pucrs.br/ffch/filosofia/pos/cebel/ArtigoMariaAfonso.pdf

Alakurt, T.; Bardakçi, S. e Keser, H. (2012), ICT Students teachers' judgements and justifications about the ethical issues. Turkish Online Journal of Qualitative Inquiry, 3(4), pp. 48-62.

Almeida, F.; Gama, P. e Peixoto, P. (2011), A Ética no ensino superior: um estudo exploratório sobre a fraude académica. Actes du XIX ${ }^{\text {ème }}$ colloque de l'AFIRSE. Deontologie, Ethique et Valeurs en Education - Utopie et réalité, pp.714-725. Lisboa EDUCA, CD, ISBN978-989-8272-14-0.

Alves, F. C. (2009), As conceções éticas dos professores do ensino superior e a influência do género. Atas do II Congresso Internacional CIDnE, Novos contextos de formação, pesquisa e mediação: Vila Nova de Gaia.

Baldi, E. e Barreto, M. A. (2011), Produtividade intelectual na docência universitária: um indicador de avaliação. Atas do xix Colóquio da AFIRSE Deontologia, Ética e Valores na Educação - Utopia e realidade, pp. 677-686. Lisboa: EDUCA. ISBN 978-989-8272-14-0.

Bauman, Z. (1997), Ética pós-moderna. São Paulo: Editora Paulus.

Boon, H. (2011), Raising the Bar: Ethics Education for Quality Teachers. Australian Journal of Teacher Education, 36(7), pp.76-93. Obtido em 9 de fevereiro de $2014 \mathrm{em} \mathrm{http://ro.ecu.edu.au/cgi/viewcontent.cgi?article=1531 \& context=ajte.}$

Chávez G. G. e Benavides, B. (2011), Los profesores universitarios: entre la exigencia profesional y el compromiso ético-social. Sinéctica, 37, pp. 1-13. Obtido em 25 de janeiro de 2014 em http://www.scielo.org.mx/pdf/sine/n37/n37a3.pdf.

Dubar, C. (1997), A socialização: construção de identidades sociais e profissionais. Porto: Porto Editora.

Ells, C. (2011), Communicating qualitative research study designs to research ethics review boards. The qualitative report volume, 16(3), pp. 881-891. Obtido em 7 de fevereiro de 2014 em http://www.nova.edu/ssss/QR/QR16-3/ells.pdf 
Estrela, M. T. (2010), Ética e Pedagogia no Ensino Superior. In C. Leite (Org.), Sentidos da Pedagogia no Ensino Superior, pp. 11-27. Porto: Livpsic.

Estrela, M. T. e Afonso, R. (2012), O pensamento ético-deontológico de docentes do Ensino Superior à luz das Atas do Colóquio da AFIRSE de 2010. Cadernos de Pesquisa, 7(16.) pp.13-57 [ISSN da versão on line: 217526123, consultável em http://www.utp.br/Cadernos_de_Pesquisa/EA/cad_pesq_16/index.html\#/1/].

Formosinho, M. D. (2007), Desafios a uma Ética Pós-Moderna. In J. Boavida e A. Garcia del Dujo, Teoria da Educação. Contributos Ibéricos, pp. 245-257. Coimbra: Imprensa da Universidade de Coimbra.

García López, R.; Ferrández, M. R.; Sales, M. A. e Moliner, M. O. (2005), El profesorado universitario ante la enseñanza de valores. Adenda do XXIV Seminario Interuniversitario de Teoría de la Educación "El Espacio Europeo de Educación Superior", pp. 1-7. Obtido em 8 de fevereiro de 2014 em http://pendientedemigracion.ucm.es/info/site/docu/24site/ad305.pdf

Gilligan, C. (1982/1997), Teoria psicológica e desenvolvimento da mulber. Lisboa: Fundação Calouste Gulbenkian.

Githui, D. (2011), Ethical Issues in Education and Training in Kenya: A Critical Analysis of Teaching Methodology. Journal of Education and Practice, 2,(3) pp. 86-103. Obtido em 1 de fevereiro de 2014 em http://www.iiste.org/Journals/index.php/ JEP/article/view/203/88

Gutiérrez, S. e Barrón,T. C. (2011), A responsabilidade social nos projetos de pesquisa educativa. Atas do xix Colóquio da AFIRSE Deontologia, Ética e Valores na Educação-Utopia.e realidade, pp.633-639. Lisboa: EDUCA. ISBN 978-9898272-14-0.

Hirsch, A. A. (2006), Construcción de un estado del conocimiento sobre valores profesionales en México. Revista Eletrónica de Investigación Educativa, 8(2). Obtido em 2 de fevereiro de 2014 em: http://redie.uabc.mx/vol8no2/contenido-hirsch2.html

Hirsch, A. A. (2009), Competencias y rasgos de ética profesional en estudiantes y profesores de posgrado de la UNAM. Sinéctica, revista virtual de educación, 32, enero-junio. Obtido em 7 de janeiro de 2014 em http://portal.iteso.mx/ portal/page/portal/Sinectica/Revista/SIN32_08/sin32_hirsh.pdf 
Hirsch, A. A. (2010), La formación en ética profesional y los profesores de posgrado de la Universidad Nacional Autónoma de México. Revista Eletrónica de Investigación Educativa [Número Especial]. Obtido em 10 de fevereiro de 2014 em http://redie.uabc.mx/NumEsp2/contenido-hirsch3.html

Hirsch, A. A. e Pérez-Castro, J. (2013), Estado de conocimiento sobre valores profesionales y ética profesional. Memoria de la IX Jornada Nacional de Investigadores en Educación y Valores. Obtido em 23 de janeiro de 2014 em http://www.iberopuebla.edu.mx/servicios/memorias/files/panel_estados_del_conocimiento/estado_del_conocimiento_sobre_valores_profesionales_y_etica_profesional.pdf

Jamil, M.; Shah, J. e Tariq, R. (2013), IT Ethics: undergraduates' perception based on their awareness. Journal of Education and Practice, 4(12), pp.110-123. Obtido em 8 de fevereiro em http://www.iiste.org/Journals/index.php/JEP/article/ view/6529/6487

Jonas, H. (1993/1998), Pour une éthique du future, Paris: Editions Payot e Rivage.

Levinas. E. (1982/2007), Ética e Infinito. Lisboa: Edições 70.

Loureiro, R. C.; Pequeno, H. S. L.; Pequeno, M.; Sarmento, W. W. F.; Silva, H.; Barone, N.; Vasconcelos, H. L. (2011), Avaliação de Conteúdos Educacionais Digitais: o modelo do Instituto UFC Virtual. Em: SBIE e $17^{\circ}$ WIE, 2011. Aracaju. SBIE e $17^{\circ}$ WIE, 2011. Aracaju: SBIE, v. 1.

Macfarlane, B. (2004), Teaching with integrity: The ethics of higher education practice. Londres: Routledge Falmer.

MacIntyre, A. (1986), Tras la virtud. Barcelona: Editorial crítica.

Marginson, S. (2007), Globalization, the "Idea of University" and its Ethical Regimes. Higher Education Management and Police, 19(1), pp. 31-45.

Mathenge, G. (2012), Ethical dimensions in responsible professionalism and accounting procedures in Kenya: a critical analysis of theory and practice. Research Journal of Finance and Accounting, 3(2), pp. 58-70.

Moore, G. (2006), Making ethics in higher Education: implementing a code or embedding virtue? Business Ethics: A European Revue, 15(4), pp. 407-418.

Murphy, M. S.; Pinnegar, E. e Pinnegar, S. (2011), Exploring ethical tensions on the path to becoming teacher. Teacher Education Quarterly, Fall 2011, pp. 97-113. 
Noddings, N. (2001), The caring teacher. In V. Richardson (Org.) Handbook of Research of Teaching, pp. 99-105. Washington D.C.: American Educational Research Association. Oghuvbu, E, P. e Okpilike, F. E. M. (2012), Common Ethical Issues in delta state Schools. An Emprical Analysis. Journal of Education and Practice, 3 (13). Obtido em 24 de janeiro de 2014 em http://www.iiste.org/Journals/index.php/ JEP/article/view/3055/3096. ISSN (On line) 2222-288X.

Oliveira, A. L. (2012), A presença da ética na formação inicial de professores. Atas do VI Colóquio Internacional "Educação e Contemporaneidade, pp. 1-11.

Oliveira, E. L.; Thomé, V. A. e Andrade, E. (2011), Comportamento ético de estudantes do ensino superior. Atas do xix Colóquio da AFIRSE, Deontologia, Ética e Valores na Educação - Utopia e realidade, pp. 802-815. Lisboa: EDUCA. ISBN 978-989-8272-14-0.

Poisson, M. (2011), Ethique et corruption dans l'éducation. Actes du xix ème colloque de l'AFIRSE, Deontologie, Ethique et Valeurs en Education - Utopie et réalité, pp.15-23. Lisboa: EDUCA, CD, ISBN ISBN 978-989-8272-14-0.

Ramos, K. (2011), Docência Universitária: uma reflexão sobre esta profissionalidade docente. Atas do xix Colóquio da AFIRSE, Deontologia, Ética e Valores na Educação - Utopia e realidade, pp. 167-180. Lisboa: EDUCA. ISBN 978-989-8272-14-0.

Ricoeur, P. (1990), Soi-même comme un autre. Paris: Editions du Seuil.

Rodrigues, K.; Matos, E. e Barni, E. (2011), A utilização de ambientes virtuais de aprendizagem na formação ética do professor. Atas do xix Colóquio da AFIRSE Deontologia, Ética e Valores na Educação - Utopia e realidade, pp.735-742. Lisboa: EDUCA. ISBN 978-989-8272-14-0.

Romanowski, J. e Martins, P. (2011), A contribuição das comissões de ética em pesquisa na formação ética do pesquisador. Atas do xix Colóquio da AFIRSE, Deontologia, Ética e Valores na Educação - Utopia e realidade, pp. 626-632. Lisboa: EDUCA. ISBN 978-989-8272-14-0.

Sabbe, E. e Aelterman, A. (2007), Gender in teaching: a literature review. Teachers and Teaching: theory and practice, 13(5), pp. 521-538.

Sadlak, J. e Ratajczak, H. (2004), Academic freedom, innovation, and responsibility: Towards an 'Ethical GPS' in higher education and science. Higher Education in Europe, Vol. XXIX,(4), pp.433-438. 
Sales C. A.; García L. R.; Moliner, O. e Fernández, R. (2007), El papel del profesorado universitario en el desarrollo de la competencia profesional ética. DIDAC. Formación por competencias, 49, pp. 28-32. Obtido em 7 de fevereiro de 2014 em http://www.uia.mx/web/files/didac/49.pdf

Sousa, S. (2011), Um pacto alicerçado no EDUCARE AD EDUCERE: moral versus indisciplina. Atas do xix Colóquio da AFIRSE, Deontologia, Ética e Valores na Educação - Realidade e utopia, pp. 792-801. Lisboa: EDUCA. ISBN 978-989-8272-14-0.

Szostek, A. (2004), Morality, Culture and Modernity: Challenges to the University. Higher Education in Europe, vol. XXVX(4), pp. 467-474.

Valentini, M. T. e Tsukamoto, N. (2011), Ética nos cursos de licenciatura: um desafio contemporâneo. Atas do xix Colóquio da AFIRSE, Deontologia, Ética e Valores na Educação - realidade e utopia, 784-791. Lisboa: EDUCA. ISBN 978-9898272-14-0.

Walker, M. (2011), Evaluating the intervention of an ethics class in student's ethical decision-make. Journal of Scholarship of Teaching and learning, 11(4) pp. 69-89.

Winder, B; Brunsden, V. e Farnsworth, B. (2007), Student research and ethics; contributing to the debate. Psychology Teaching Review, 13(1), pp. 48-50. Obtido em 6 de fevereiro de $2014 \mathrm{em} \mathrm{http://files.eric.ed.gov/fulltext/EJ876477.pdf}$

Wongchantra, P; Boujai, P.; Sata, W. e Neungchalerm, P. (2008), A Development of Environmental Education Teaching Process by Using Ethics Infusion for Undergraduate Students. Pakistan Journal of Social Sciences, 5(9) pp.941-944. Obtido em 5 de fevereiro de 2014 em http://docsdrive.com/pdfs/medwelljournals/pjssci/2008/941-944.pdf

\section{Documentos referidos}

Magna Charta Universitatum (1988), Obtido em 25 de fevereiro em http://www.bologna-bergen2005.no/Docs/00-Main_doc7880918_Magna_Charta_Universitatum.\%20pdf Ministério da Ciência, Tecnologia e Ensino Superior (2008), Despacho Normativo 43/2008, 168, 2. ${ }^{a}$ série. Obtido em 20 de dezembro de 2013 em http://www. uc.pt/assembleiaestatutaria/Estatutos_UC/Estatutos_-_Publicacao_DR.pdf 
Ministério da Ciência, Tecnologia e Ensino Superior (2009), Despacho normativo 18-A/2009, 93, 2. ${ }^{a}$ série. Obtido em 20 de dezembro de 2013 em https://www. ua.pt/ReadObject.aspx?obj=32481

Ministério da Ciência, Tecnologia e Ensino Superior (2009), Despacho normativo 18-B/2009, 93, 2. ${ }^{a}$ série. Obtido em 20 de dezembro de 2013 em http://sigarra. up.pt/fep/pt/legislacao_geral.ver_legislacao?p_nr=577

Ministério da Educação (1998), Despacho Normativo 11-A/98, 44, I Série B. Obtido em 20 de dezembro de 2013 em http://www.dre.pt/pdf1s\%5C1998\%5C02\%5C044B01\%5C00020012.pdf

Ministério da Educação e Ciência (2013). Despacho normativo 5-A/2013. In Diário da República, 77, 2. ${ }^{a}$ série. Obtido em 20 de dezembro de 2013 em www.ulisboa. pt/wp-content/uploads/Legislação_Final/estatutos_ULisboa_DR2.pdf

Provedor do estudante da Universidade de Aveiro (2013). Relatório anual 2012. Obtido em 20 de dezembro de 2013 em http://www.ua.pt/conselhogeral/PageText. aspx?id=15441

The Bucarest Declaration Concerning Ethical Values and principles for Higher Education in the Europe Region (2004), Higher Education in Europe, 29(4), pp. 503-507. Obtido em 25 de fevereiro de 2009 em http://dx.doi. org/10.1080/03797720500083922

UNESCO. (1998). World declaration on higher education for the twenty-first century: Vision and action. Obtido em 17 de novembro de $2008 \mathrm{em}$ http://www.unesco. org/education/educprog/wche/declaration_eng.htm

University of Bath Quality Assurance Code of Practice, "QA53 -Examination and Assessment Offences". Obtido em 26 de dezembro de 2013 em http://www.bath.ac.uk/quality/documents/QA53.pdf 
(Página deixada propositadamente em branco.) 


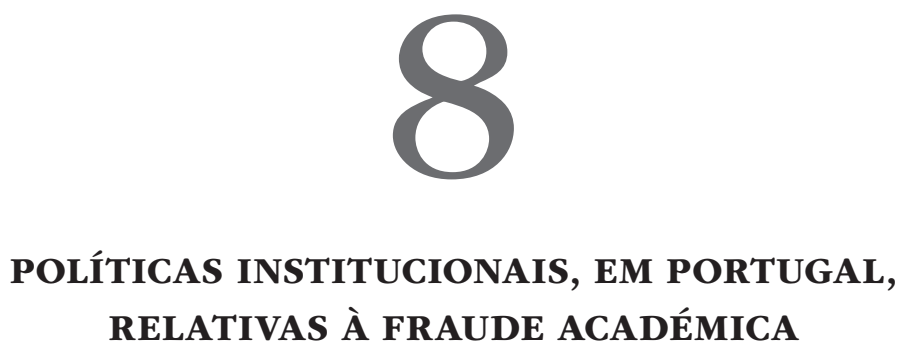

Paulo Peixoto

Denise Esteves

Ana Seixas

Filipe Almeida

Paulo Gama

Universidade de Coimbra

bttp://dx.doi.org/10.14195/978-989-26-1123-5_8 
(Página deixada propositadamente em branco.) 


\subsection{A cultura da integridade académica}

Em Portugal, o levantamento exaustivo da existência de códigos preventivos e punitivos da fraude académica está por realizar. Sabemos, todavia, que à volta desta questão emergem preocupações crescentes, não sendo de estranhar que, em parte, as mesmas resultem do facto de, no plano internacional, cada vez mais instituições se dotarem de códigos de ética ou de conduta; ou de, no mínimo, desenvolverem formalmente medidas preventivas que visam promover a integridade académica. As preocupações e as atitudes dos estudantes e dos docentes portugueses perante o fenómeno da fraude académica apelam também à existência de procedimentos formais que permitam às instituições enfrentar as práticas fraudulentas dos estudantes (Almeida et al., 2015). Porém, a inexistência de códigos formais não significa que as instituições estejam desprovidas de uma cultura ética. Pelo contrário. A cultura ética é algo que se forma gradual e situacionalmente, a partir de um conjunto diverso de fatores, específicos em cada instituição, precedendo a formalização escrita de regras e padrões comportamentais (Bergadaà, 2015). E, não raras vezes, as barreiras à adesão às regras formais escritas repousam, precisamente, numa cultura ética informal mas consolidada. Acreditamos, como sugerem Macdonald e Carroll (2006), que a formalização de procedimentos visando a promoção da integridade académica resulta da imposição gradativa de uma abordagem institucional mais holística que apela à necessidade de uma responsabilidade partilhada entre estudantes, docentes e instituições e devidamente caucionada por agentes externos. 
A integridade académica está longe de ser uma preocupação recente das instituições de ensino superior. Foram muitos os estudos que se debruçaram sobre o conceito e sobre a sua relação com códigos de conduta. ${ }^{22}$ Além disso, a integridade académica assume naturezas e alcances diferenciados, envolvendo questões muito variadas ao longo da história (Gallant, 2008). Ainda assim, é, pode dizer-se, uma das maiores e mais complexas preocupações e desafios do atual universo académico, pelo menos nas sociedades ocidentais desenvolvidas (Hallak e Poisson, 2002).

$\mathrm{Na}$ universidade que apenas formava elites, a integridade académica centrava-se na esfera pessoal e tinha, sobretudo, a ver com os valores de dever, honra e boa reputação pessoal. Porém, a partir do século $\mathrm{xx}$, particularmente com a diversificação dos papéis da universidade, e com a massificação e universalização do ensino superior, a integridade académica assumiu novas dimensões e ganhou novos contornos institucionais. Ainda mais recentemente, o uso crescente das novas tecnologias (Manly, Leonard e Riemenschneider, 2014), a competição gradual entre instituições (Heyneman, 2013) e a afirmação no mercado de trabalho por via da posse de um grau académico (Pedersen, 2015), conferem um novo alcance e uma nova profundidade ao conceito.

A integridade académica é um fenómeno transversal na medida em que pode ser ferida pelos estudantes, pelos docentes, por funcionários das instituições de ensino superior, por agentes externos, ou mesmo pelas próprias instituições quando definem e executam políticas educativas. Sublinhando esta complexidade, Gallant (2008) identifica quatro dimensões da integridade académica: uma dimensão interna (que remete para o caráter dos estudantes); uma dimensão organizacional (que tem a ver com normas que regulam as relações

22 Ver, por exemplo, McCabe, Treviño e Butterfield (2002); Macfarlane, Zhang e Pun (2014). 
entre pares e as dinâmicas das salas de aula); uma dimensão institucional (relativa aos sistemas académicos); e, por fim, uma dimensão societal (que tem a ver com dinâmicas externas). O que significa que a integridade académica não é um fenómeno individual e isolado, mas sim um facto social multifacetado, situando-se num enquadramento institucional e podendo a sua violação ser frequentemente impercetível. A fraude académica cometida por estudantes, tal como a consideramos em Almeida, Gama e Peixoto (2010) e em Almeida et al. (2015), é uma ilustração perfeita da dimensão oculta das formas de violação da integridade académica. A apropriação de trabalho de outra pessoa (com ou sem a colaboração ativa de outrem); a simulação de um trabalho não realizado (autoplágio ou falsificação de dados ou resultados); a facilitação da fraude a terceiros (com benefício próprio para quem a facilita, com risco de prejuízo próprio para quem a facilita ou com efeito neutro para quem a facilita); e a ocultação da fraude (não denúncia da fraude cometida por terceiros) são, todas elas, tipos de fraudes cometidas por estudantes que põem em evidência o alcance e a densidade do conceito de integridade académica. Essa densidade e alcance do conceito tornam-se, naturalmente, ainda mais consistentes na medida em que considerarmos, como deve ser feito, outros agentes além dos estudantes.

Em suma, uma cultura de integridade académica tem de ser desenvolvida num contexto societal e também no âmbito de uma estratégia institucional que procure identificar, prevenir e punir diferentes formas de violação da integridade académica. Nessa medida, não começa, nem acaba na academia. Além disso, pressupõe um nível adequado de formalização. Considerando o caráter amplo do conceito, Michelle Bergadaà (2013) propõe um projeto institucional integrado que seja capaz de operacionalizar a integridade académica. Esse projeto baseia-se num plano de ação com 12 medidas: envolver a gestão da instituição; constituir um grupo de trabalho; promover debates em torno do valor do conhecimento; fomentar as competências acerca 
do uso adequado da Internet; promover debates sobre ética; usar um software de deteção de plágio; elaborar um regulamento pedagógico e deontológico; formar e informar os estudantes; informar os professores; formalizar um sistema de queixas; fazer o acompanhamento de casos com os professores; e especificar e aplicar sanções.

\subsection{A integridade académica nos códigos das instituições de ensino superior em Portugal}

O enquadramento formal que as instituições de ensino superior fazem relativamente à integridade académica passa, genericamente, pela elaboração de códigos de conduta ou de regulamentos de enquadramento da fraude académica. Na sua natureza, são documentos de índole diferenciada, simbolizando a diversidade de políticas institucionais. Os primeiros tendem a ter um alcance mais formativo e preventivo, difundindo valores de honorabilidade e padrões éticos. Os segundos tendem a fixar dimensões disciplinares e punitivas da violação da fraude académica. Mas, na sua origem, os dois tipos de documentos têm também a ver com culturas académicas e com áreas e tradições disciplinares. E, no seu alcance, se os primeiros tendem a ser mais amplos em termos de abrangência de atores, os segundos tendem a ser mais restritos, dirigindo-se especificamente às condutas dos estudantes.

Conhecedores da amplitude dos códigos institucionais enquadradores das questões da integridade académica, e sabendo que nas instituições de ensino superior portuguesas as preocupações com a integridade académica entram marginal e genericamente nos documentos formais, considerámos, ainda assim, ser relevante proceder, nesta matéria, a uma análise documental dirigida à realidade nacional.

A operacionalização do levantamento e análise partiu de uma pesquisa realizada na Internet e nas páginas eletrónicas das instituições, 
complementada com consultas a instituições, agrupando-se os documentos selecionados por subsistemas de ensino (universitário público e universitário privado; ou politécnico público e politécnico privado). A tarefa de levantamento e análise foi efetuada entre 2011 e 2013.

Pretendeu-se, por um lado, dar conta das dimensões das políticas institucionais formalizadas que se reportam à integridade académica e, por outro lado, caracterizar com algum detalhe o contexto normativo, de modo a identificar práticas e princípios enquadradores da integridade académica no ensino superior português.

A partir de um olhar sistematizado, foi possível identificar, com base nos documentos consultados, as principais tendências e, em alguns casos, as inconsistências, presentes nas políticas internas das instituições portuguesas de ensino superior e de diferentes unidades orgânicas. Foi igualmente possível referenciar e explicitar os modos de atuação de diversas instituições de ensino superior perante questões inerentes à integridade académica, designadamente quando esta se relaciona particularmente com as práticas dos estudantes. A análise permite fazer inferências sobre a natureza das estratégias e a eficácia das medidas institucionais em matéria de promoção da integridade académica, numa perspetiva comparativa entre os sistemas (público e privado) e os subsistemas (universitário e politécnico) do ensino superior português.

A análise que em baixo se desenvolve focaliza-se na dimensão institucional da integridade académica. Estamos conscientes da importância do domínio do "informal"; isto é, da dimensão simbólica, das práticas não oficiais e dos significados construídos subjetivamente. Mas o domínio do informal não deixa de estar enquadrado por uma dimensão formal, que se começa a constituir com a autonomia disciplinar instituída pelo Regime Jurídico das Instituições do Ensino Superior (RJIES), que daí se transfere para os estatutos das instituições e, por fim, para códigos e regulamentos internos. É a partir desta última dimensão formal, composta por normas 
e por padrões, que se poderão problematizar as condutas individuais e subjetivas dos diferentes agentes. Questionando, designadamente, os sentidos e os significados que esses agentes atribuem às suas práticas; as racionalidades que se impõem em cada instituição; assim como as inconsistências entre a cultura organizacional formal e as "realidades vividas" pelos agentes no seio das instituições do ensino superior português.

Independentemente da eficácia desses códigos e regulamentos (que denunciam frequentemente a sua incapacidade operativa por serem elementos isolados, e instrumentos com um caráter pouco mais que o meramente formal, do que seria uma política integrada de promoção da integridade académica e de combate à fraude), a sua existência deve ser encarada como suporte de uma política institucional de promoção da integridade académica. Sendo necessários mas não suficientes, concorrem para a criação de uma cultura académica transversal baseada em princípios que devem regular os comportamentos da comunidade. Em teoria, implicam todos os atores da comunidade académica, e as instituições em primeiro lugar, na problemática da integridade e da fraude, assim como nas medidas a adotar nessas matérias.

Numa perspetiva institucionalista, o quadro normativo constituído por códigos e regulamentos formata e determina o funcionamento formal das instituições de ensino superior, particularmente na relação entre dois domínios cruciais desse tipo de instituições: o domínio administrativo-funcional (onde, predominantemente, emergem comissões de ética) e o domínio mais científico-pedagógico (onde emergem códigos de conduta e outros regulamentos de cariz disciplinar). Embora essa não seja a preocupação concreta deste texto, a questão que em última instância se coloca é a de saber em que medida o quadro normativo que envolve a problemática da integridade académica configura dinâmicas institucionais capazes de alterar as práticas dos principais agentes das instituições de ensino superior 
(em concreto, professores e estudantes). Importaria, no fundo, perguntar: i) quão efetivas são as políticas institucionais na promoção da integridade académica e no combate à fraude académica?; ii) como são encaradas e postas em prática essas políticas pelos diferentes agentes (estudantes, professores)?; iii) de que modo e até que ponto estão sintonizadas as políticas institucionais relativas à integridade e as realidades empíricas das instituições de ensino superior em Portugal?; iv) estarão os estudantes e docentes das instituições de ensino superior onde existe um código de conduta mais comprometidos com a manutenção de uma cultura de integridade académica? ${ }^{23}$; v) estarão os estudantes e os docentes das instituições que dispõem de códigos de conduta mais propensos a denunciar casos de fraude académica dos colegas? Embora as respostas a estas perguntas só sejam possíveis a partir de um estudo amplo e transversal sobre a integridade académica (combinando visões de estudantes, de professores, de responsáveis institucionais e de agentes externos), a análise da natureza e do alcance dos códigos e regulamentos é fundamental na medida em que os arranjos institucionais influenciam as condutas prevalecentes.

Referenciar a própria existência de documentos institucionais que enquadrem a integridade académica é uma tarefa tão árdua quanto tipificá-los. A divulgação pública de códigos e regulamentos não é uma prática generalizada das instituições de ensino superior portuguesas. Por si mesmo, esse fator é revelador do estatuto e das funções desse tipo de documentos. Existem, muitas vezes, porque têm de existir dentro da "política comunicacional" das instituições e não para consolidar uma cultura ampla de prevenção e de combate à fraude e

\footnotetext{
23 Para enquadrar esta questão, lembramos que em Almeida et al. (2015) verificamos serem muito significativas as percentagens de alunos e docentes que confessam não saber se a sua instituição dispõe ou não de um código de boas práticas ou regulamento disciplinar. Sendo igualmente significativas as proporções daqueles que, sabendo que existe na sua instituição um código de boas práticas ou regulamento disciplinar, confessa nunca o ter lido.
} 
um compromisso institucional com a integridade. Por outro lado, há uma clara tendência para que esses documentos se concentrem no sistema público de ensino superior, ou para que seja aí que eles se tornem objeto de maior divulgação. A tipificação torna-se, também ela, um desafio difícil, uma vez que, não existindo um enquadramento geral, e conferindo o RJIES uma autonomia declarada nessa matéria, cada instituição desenha e nomeia os documentos que enquadram a integridade académica da forma que bem entende. Ainda assim, foi possível e tido por útil elencar 7 tipos de documentos pertinentes (Cfr. Tabela 1), ainda que as fronteiras que os distinguem nem sempre sejam muito nítidas e que o tipo de medidas de promoção da integridade que encontramos num determinado tipo de documentos se encontre, por vezes, noutro tipo de documento. Uns comportam medidas mais gerais e outros incluem medidas mais específicas.

TABELA 1 - DOCUMENTOS CONSULTADOS POR TIPO E POR SUBSISTEMA

\begin{tabular}{|l|c|c|c|c|c|}
\hline TIPO DE DOCUMENTO & UPU & UPR & PPU & PPR & TOTAL \\
\hline CÓDIGO DE CONDUTA & 6 & 0 & 2 & 1 & 9 \\
\hline $\begin{array}{l}\text { REGULAMENTO ACADÉMICO } \\
\text { E PEDAGÓGICO }\end{array}$ & 9 & 3 & 12 & 1 & 25 \\
\hline $\begin{array}{l}\text { REGULAMENTO DISCIPLINAR } \\
\text { DOS ESTUDANTES }\end{array}$ & 6 & 1 & 1 & 2 & 10 \\
\hline $\begin{array}{l}\text { REGULAMENTO DO } \\
\text { FUNCIONAMENTO DOS } \\
\begin{array}{l}\text { CURSOS E REGULAMENTO } \\
\text { DE AVALIAÇÃO }\end{array}\end{array}$ & 29 & 7 & 38 & 3 & 77 \\
\hline ESTATUTOS & 17 & 2 & 8 & 1 & 28 \\
\hline $\begin{array}{l}\text { CARTAS DE DIREITOS E } \\
\text { DEVERES DA COMUNIDADE } \\
\text { ACADÉMICA }\end{array}$ & 1 & 0 & 0 & 0 & 1 \\
\hline GUIA DO ESTUDANTE & 0 & 2 & 0 & 0 & 2 \\
\hline TOTAL & 68 & 15 & 61 & 8 & 152 \\
\hline
\end{tabular}

\section{Legenda:}

UPU - Estabelecimento de ensino Universitário Público

UPR - Estabelecimento de ensino Universitário Privado

PPU - Estabelecimento de ensino Politécnico Público

PPR - Estabelecimento de ensino Politécnico Privado 
Globalmente, os 152 documentos recolhidos foram analisados de modo a referenciar: padrões comportamentais divulgados como adequados em contexto académico; definições conceptuais de comportamentos fraudulentos; estratégias institucionais para a prevenção desses comportamentos; estabelecimento de mecanismos de deteção de modalidades de fraude académica; sanções académicas e/ou disciplinares dos comportamentos inadequados ou fraudulentos. Esta primeira abordagem conduziu depois a uma análise mais detalhada dos documentos considerados mais relevantes (Tabela 2).

Uma caraterização sumária permite concluir que os documentos consultados remetem para um conceito de integridade académica vago e impreciso. Não foi possível encontrar documentos que, isolados ou combinados, cobrissem a questão da fraude académica em toda a sua complexidade e que apontassem para uma política integrada de prevenção e de combate. Ou seja, que não se limitassem a uma referenciação protocolar ou a uma circunscrição conceptual da fraude, e que instituíssem mecanismos de prevenção, estratégias de deteção e, por fim, um quadro de sanções a aplicar aos estudantes. É raro que a questão da integridade académica seja colocada no plano das condutas dos docentes e da atuação da instituição, o que denota a incapacidade ou a falta de vontade em atuar no contexto em que ela se concretiza e é infringida. A análise documental permite-nos perceber que, para a maioria das instituições de ensino superior, os comportamentos que configuram fraude académica são enquadrados apenas numa ou duas das dimensões em cima mencionadas (o mais comum é encontrar-se uma referência conceptual vaga e a previsão de mecanismos disciplinares nem sempre especificados). Como se pode ver na Tabela 1, onde os Estatutos e os Regulamentos de funcionamento dos cursos e de avaliação sobressaem como tipo de documento mais numeroso, a política institucional de promoção da integridade académica balança entre o caráter genérico dos estatutos 
e as normas a respeitar pelos estudantes no domínio do funcionamento dos cursos e das práticas de avaliação.

Associadas a códigos de conduta, as comissões de ética que, por regra, tendem a incluir questões relacionadas com a investigação, e não apenas com a docência; que atuam numa área cada vez mais estratégica para as universidades (as atividades de extensão); e que tendem a ser compostas por elementos internos e externos às instituições, promovendo um maior escrutínio do respeito pela integridade, são uma raridade no universo das instituições portuguesas de ensino superior, ainda que várias instituições tenham vindo a adotar este mecanismo. É, sobretudo, nas instituições onde são lecionados cursos na área da saúde e onde a experimentação laboratorial se constitui usualmente enquanto prática pedagógica e de investigação que maioritariamente encontramos comissões de ética e/ou códigos de conduta. Compete-lhes regular o funcionamento da atividade laboratorial e clínica e a conduta dos docentes, estudantes e investigadores. Contudo, a ação das comissões de ética não se esgota aí, considerando não só as questões éticas relacionadas com a investigação, nomeadamente na área das "biociências", mas também sobre eventuais casos de fraude académica protagonizados por estudantes, docentes ou investigadores; ou mesmo sobre "questões comportamentais", como "excessos de praxes académicas e assédio de diversos tipos" (e. g. Universidade do Minho). Compete-lhes ainda acompanhar projetos de investigação, sobretudo aqueles que envolvam temas sensíveis, nomeadamente, aqueles que incluam (sob qualquer forma) pessoas, animais ou material biológico proveniente de pessoas ou animais, além daqueles que são específicos às ciências sociais e humanas, às tecnologias e às artes (e. g. Universidade do Porto). Em algumas instituições, este órgão ressalva a missão de zelar pela observância e promoção de padrões de integridade, honestidade e responsabilidade na atividade das unidades de ensino e de investigação nas suas relações internas e externas, bem como na 
conduta dos seus membros (e. g. UTAD). Assim, são organismos que se manifestam sobre questões éticas suscitadas nas áreas do ensino, da investigação científica, da prestação de serviços à comunidade e do funcionamento da instituição (e. g. ISCTE-IUL). Estes organismos, bem como os seus membros, estão ainda intimamente ligados à planificação e execução dos códigos de conduta e de boas práticas. Neste contexto emergem documentos, regulamentos e recomendações que são disponibilizados a toda a comunidade académica.

Enquadrando esta dimensão da integridade académica, o RJIES estipula que "Para além das normas legais, estatutárias e regulamentares a que estão sujeitas, as instituições de ensino superior podem definir códigos de boas práticas em matéria pedagógica e de boa governação e gestão" (RJIES, $\mathrm{n}^{\circ} 7$, artigo $9^{\circ}$ ). Neste âmbito, várias instituições têm vindo a adotar códigos de conduta e de boas práticas. Os códigos de conduta e boas práticas existentes nas instituições de ensino superior portuguesas estabelecem um conjunto de normas que pretendem conduzir os comportamentos dos seus funcionários, professores e estudantes; bem como orientar a missão das instituições nos processos de ensino-aprendizagem, de formação e de investigação científica, em concordância com a lei geral e com os estatutos das instituições e demais regulamentos e legislação aplicável. Os códigos de conduta e de boas práticas consultados têm, portanto, um espetro alargado de destinatários, incluindo como alvo das suas normas, além dos estudantes, os docentes, os investigadores e restantes trabalhadores não docentes e não investigadores das instituições de ensino superior. São exemplos os códigos de conduta da Universidade Técnica de Lisboa (2009); Universidade do Porto (2010); Universidade da Madeira (2010); Universidade do Minho (2012); ISCTE-IUL (2008); Universidade de Aveiro (2008).

Deste modo, os códigos de conduta integram uma visão de responsabilidade e de conduta partilhada entre os estudantes, a restante comunidade académica e as próprias escolas/departamentos/ 
faculdades e/ou universidades nas questões relacionadas com a integridade académica. Outros códigos referem-se às normas que devem ser seguidas exclusivamente pelos trabalhadores que exercem funções nas respetivas instituições. São exemplos, os códigos de conduta do Instituto Politécnico de Lisboa e do Instituto Politécnico de Portalegre. Outras instituições, além destes códigos de conduta, elaboraram documentos exclusivamente orientados para tratar da questão da fraude académica entre estudantes, como, por exemplo, a Universidade de Aveiro (Carta de conduta dos estudantes da universidade de Aveiro) e a Universidade da Madeira (Despacho ${ }^{\circ}$ 140/R/2009 - Deteção de Plágio).

Enquanto instrumentos para a regulação de comportamentos concretos da comunidade académica, a maioria dos documentos consultados revela uma ineficiência regulamentar no domínio das medidas preventivas da fraude académica. Além disso, existem diferenças interinstitucionais sobre o que é considerado um comportamento íntegro, bem como sobre as medidas a adotar para a sua prevenção, deteção e punição. Uma orientação mais clara e definida dirigida às políticas institucionais, no sentido de delimitar o espectro da sua abrangência e de enquadrar diferentes formas e níveis de manifestação da fraude académica, está limitada pelo facto de o RJIES apenas sugerir, não impondo, nem circunscrevendo regulamentação específica. O que maioritariamente acontece é o desenvolvimento de distintas conceções de fraude académica e do que é um comportamento fraudulento no seio da comunidade académica, estando estas definições dependentes de circunstancialismos organizacionais e dos seus modelos pedagógicos. Estas conceções são altamente permeáveis à subjetividade de quem as avalia, produzindo respostas, muitas vezes individuais e ocasionais, dependendo da interpretação de cada unidade orgânica, departamento ou escola ou das motivações circunstanciais das lideranças institucionais. Estas diferentes interpretações introduzem subjetividade também na definição das 
medidas de prevenção e das sanções académicas e/ou disciplinares a aplicar em caso de fraude. Convém referir, relativamente às atitudes disciplinares, que o artigo $\mathrm{n}^{\circ} 75$ do RJIES concede autonomia disciplinar às instituições de ensino superior públicas, significando que cada instituição tem a capacidade de punir estudantes, docentes, investigadores e outros funcionários com algum grau de autonomia. No que concerne aos estudantes, o disposto nos números 4, 5 e 6 do referido artigo rege esse poder disciplinar, que está também abrangido por estatutos e regulamentos próprios das diversas unidades orgânicas das instituições de ensino superior, com aplicação subsidiária do estatuto disciplinar dos trabalhadores da função pública, aplicável aos docentes e investigadores da instituição. Isto poderá resultar numa aplicação inconsistente das políticas institucionais e num tratamento diferenciado dos estudantes.

\subsection{Natureza dos documentos analisados}

Tal como sistematizado na Tabela 1, para dar conta das dimensões da integridade académica plasmadas em documentos elaborados pelas instituições de ensino superior, foram consultados: códigos de conduta; regulamentos académicos e pedagógicos; regulamentos disciplinares dos estudantes; regulamentos do funcionamento dos cursos e regulamentos de avaliação; estatutos; cartas de direitos e deveres da comunidade académica; e guias do estudante.

Na Tabela 2 pode verificar-se que, para o subsistema universitário público foram analisados os códigos de conduta das universidades de Aveiro, do Instituto Superior de Ciências do Trabalho e da Empresa Instituto Universitário de Lisboa (ISCTE-IUL), da Madeira, do Minho, do Porto e da Técnica de Lisboa. Para o subsistema politécnico público foram consultados os códigos de conduta dos institutos politécnicos de Lisboa e de Portalegre. Sendo as únicas instituições a divulgar os 
códigos de conduta, nenhum dos documentos consultados faz referência à questão da fraude académica. Foram ainda consultados os documentos produzidos por cinco comissões de ética e deontologia ${ }^{24}$ das instituições de ensino superior. Abordamos mais adiante estas comissões e os documentos por elas produzidos e/ou divulgados. Por fim, no subsistema politécnico privado retemos o código de conduta do Instituto Superior de Administração e Gestão (ISAG).

Em relação aos regulamentos pedagógicos, examinamos documentos de 3 subsistemas. Para o universitário público, observamos os regulamentos pedagógicos das universidades do Algarve, de Aveiro, de Coimbra, de Évora, de Lisboa e do Porto. Os das universidades Portucalense e Fernando Pessoa para o universitário privado. E, por fim, para o politécnico público, os regulamentos pedagógicos dos institutos politécnicos de Beja, Bragança, Leiria, Lisboa, Santarém, Tomar, Viana do Castelo e Viseu.

Não sendo alvo de intensa regulamentação específica, os regulamentos disciplinares emergem no sistema público. Escrutinamos os regulamentos disciplinares das universidades de Coimbra, do ISCTE-IUL, da Madeira e da Técnica de Lisboa. E também os regulamentos disciplinares do Instituto Superior da Maia para o subsistema universitário privado; do Instituto Politécnico de Coimbra para o subsistema politécnico público; e, no caso do subsistema politécnico privado, os regulamentos disciplinares dos institutos superiores de Ciências da Administração e de Ciências Empresariais e do Turismo.

Os regulamentos de avaliação e de funcionamento dos cursos são o tipo de documento mais numeroso em termos de enquadramento de questões relativas à integridade académica. Selecionamos para uma

\footnotetext{
24 Referimo-nos nomeadamente à informação produzida pelo Conselho de Ética e Deontologia da Universidade de Aveiro e da Comissão de Ética da Universidade do Porto, bem como pelos documentos produzidos pela Comissão de Ética da Universidade do Minho e Comissão de Ética da Universidade da Madeira e, por fim, da Universidade de Trás-os-Montes e Alto Douro e que se encontram disponíveis nas páginas eletrónicas das respetivas instituições.
} 
análise mais detalhada documentos dos 4 subsistemas de ensino superior. Para o universitário público os documentos das universidades do Algarve, de Coimbra, do ISCTE-IUL, de Lisboa, da Madeira, do Minho, do Porto e da Técnica de Lisboa. Para o universitário privado, os regulamentos das universidades Autónoma de Lisboa, Lusíada, Lusófona de Humanidades e Tecnologias, Escola Superior Artística do Porto, Instituto Superior de Serviço Social do Porto e Instituto Miguel Torga. Para o subsistema politécnico público os documentos dos institutos politécnicos de Coimbra, Lisboa, Santarém, Setúbal, Viana do Castelo, Viseu e Escola Superior de Enfermagem de Lisboa. Para o subsistema politécnico privado os regulamentos da Escola Superior de Educação Paula Frassinetti; Instituto Superior de Ciências da Administração e Instituto Superior de Entre Douro e Vouga.

Os estatutos das instituições de ensino superior cobrem também questões inerentes à integridade académica. Para este tipo de documentos, cobrimos também os 4 subsistemas de ensino. No universitário público consultamos os documentos das universidades de Évora, ISCTE-IUL, Lisboa, Minho, Porto e Faculdade de Ciências e Tecnologia da Universidade Nova de Lisboa. No universitário privado os estatutos das universidades Atlântica e Católica Portuguesa. No politécnico público os documentos dos institutos politécnicos do Cávado e do Ave, de Setúbal, de Viana do Castelo, da Escola Superior de Educação de Castelo Branco, da Escola Superior de Educação do Instituto Politécnico do Porto, da Escola Superior de Enfermagem de Coimbra, da Escola Superior de Teatro e Cinema do Instituto Politécnico de Lisboa e do Instituto Superior de Engenharia de Coimbra. No politécnico privado os estatutos do Instituto Superior de Tecnologias Avançadas de Lisboa.

Dois outros tipos de documentos, o primeiro mais raro na designação que assume e o segundo por focar explicitamente a questão da fraude académica, são a "Carta de direitos e deveres da comunidade académica" (da Universidade do Porto) e o Guia do Estudante do Instituto Superior de Línguas e Administração. 
TABELA 2 - DOCUMENTOS CONSULTADOS POR INSTITUIÇÃO DE ENSINO SUPERIOR

\begin{tabular}{|c|c|c|c|}
\hline Subsistema & $\begin{array}{l}\text { Códigos de } \\
\text { conduta }\end{array}$ & $\begin{array}{l}\text { Regulamentos } \\
\text { académicos e } \\
\text { pedagógicos }\end{array}$ & $\begin{array}{l}\text { Regulamentos } \\
\text { disciplinares dos } \\
\text { estudantes }\end{array}$ \\
\hline UPU & $\begin{array}{l}\text { Universidade de } \\
\text { Aveiro; Universidade } \\
\text { do Minho; } \\
\text { Universidade do } \\
\text { Porto; Universidade } \\
\text { Técnica de Lisboa; } \\
\text { ISCTE-IUL; } \\
\text { Universidade da } \\
\text { Madeira. }\end{array}$ & $\begin{array}{l}\text { Universidade de Coimbra; } \\
\text { FCT da UC; FM da UC; } \\
\text { FF da UC; FCDEF da UC; } \\
\text { FFUL da Universidade de } \\
\text { Lisboa; FM da Universidade } \\
\text { do Porto; FCHS da } \\
\text { Universidade do Algarve; } \\
\text { FCHS da Universidade } \\
\text { de Évora; Departamento } \\
\text { de Engenharia Civil da } \\
\text { Universidade de Aveiro. }\end{array}$ & $\begin{array}{l}\text { Universidade da } \\
\text { Madeira; Universidade } \\
\text { Técnica de Lisboa; } \\
\text { ISCTE- IUL; } \\
\text { Universidade de } \\
\text { Aveiro } \\
\text { Universidade de } \\
\text { Coimbra. }\end{array}$ \\
\hline UPR & & $\begin{array}{l}\text { Universidade Portucalense; } \\
\text { Universidade Fernando } \\
\text { Pessoa. }\end{array}$ & $\begin{array}{l}\text { Instituto Superior da } \\
\text { Maia. }\end{array}$ \\
\hline PPU & $\begin{array}{l}\text { Instituto Politécnico } \\
\text { de Lisboa; } \\
\text { Instituto Politécnico } \\
\text { de Portalegre }\end{array}$ & $\begin{array}{l}\text { Instituto Politécnico de } \\
\text { Beja; Instituto Politécnico de } \\
\text { Bragança; Instituto Politécnico } \\
\text { de Leiria; Instituto Politécnico } \\
\text { de Lisboa; Instituto Politécnico } \\
\text { de Viana do Castelo; Instituto } \\
\text { Politécnico de Santarém; } \\
\text { Instituto Politécnico de Tomar; } \\
\text { Instituto Politécnico de Viseu }\end{array}$ & $\begin{array}{l}\text { Instituto Politécnico } \\
\text { de Coimbra; Instituto } \\
\text { Superior de Ciências } \\
\text { da Administração }\end{array}$ \\
\hline PPR & $\begin{array}{l}\text { Instituto Superior } \\
\text { de Administração e } \\
\text { Gestão }\end{array}$ & & $\begin{array}{l}\text { Instituto Superior de } \\
\text { Ciências Empresariais } \\
\text { e do Turismo }\end{array}$ \\
\hline
\end{tabular}




\begin{tabular}{|c|c|c|c|}
\hline $\begin{array}{l}\text { Regulamento do } \\
\text { funcionamento dos } \\
\text { cursos e de avaliação }\end{array}$ & Estatutos & $\begin{array}{l}\text { Carta de } \\
\text { direitos e } \\
\text { deveres da } \\
\text { comunidade } \\
\text { académica }\end{array}$ & $\begin{array}{l}\text { Guia do } \\
\text { estudante }\end{array}$ \\
\hline $\begin{array}{l}\text { FEUC, FLUC e FPCEUC da } \\
\text { Universidade de Coimbra; } \\
\text { Universidade da Madeira; } \\
\text { Faculdade de Motricidade } \\
\text { Humana, Faculdade de } \\
\text { Arquitetura, ISEG e ISCSP } \\
\text { da Universidade Técnica de } \\
\text { Lisboa; Instituto da Educação } \\
\text { da Universidade de Lisboa; } \\
\text { FLUP e Faculdade de Direito } \\
\text { da Universidade do Porto; } \\
\text { ISCTE-IUL; Faculdade de } \\
\text { Economia da Universidade } \\
\text { do Algarve; Universidade do } \\
\text { Minho; }\end{array}$ & $\begin{array}{l}\text { Faculdade de Ciências e Tecnologia e } \\
\text { Faculdade de Ciências Sociais e Humanas } \\
\text { da Universidade Nova de Lisboa; } \\
\text { Faculdade de Medicina, Faculdade de } \\
\text { Ciências e Faculdade de Psicologia e } \\
\text { Ciências da Educação da Universidade } \\
\text { de Lisboa; Faculdade de Ciências e } \\
\text { Instituto Biomédico Abel Salazar da } \\
\text { Universidade do Porto; Escola de } \\
\text { Tecnologias e Arquitetura do ISCTE- } \\
\text { IUL; Escola de Arquitetura, Escola de } \\
\text { Ciências da Saúde, Escola de Engenharia, } \\
\text { Escola de Psicologia, Instituto de Letras } \\
\text { e Ciências Humanas e Escola Superior de } \\
\text { Enfermagem da Universidade do Minho; } \\
\text { Universidade de Évora. }\end{array}$ & $\begin{array}{l}\text { Universidade } \\
\text { do Porto }\end{array}$ & \\
\hline $\begin{array}{l}\text { Universidade Autónoma de } \\
\text { Lisboa; Universidade Lusíada; } \\
\text { Universidade Lusófona de } \\
\text { Humanidades e Tecnologias; } \\
\text { Escola Superior Artística } \\
\text { do Porto; Instituto Superior } \\
\text { de Serviço Social do Porto; } \\
\text { Instituto Miguel Torga }\end{array}$ & $\begin{array}{l}\text { Universidade Atlântica; Universidade } \\
\text { Católica Portuguesa }\end{array}$ & & $\begin{array}{l}\text { Instituto } \\
\text { Superior de } \\
\text { Línguas e } \\
\text { Administração }\end{array}$ \\
\hline $\begin{array}{l}\text { Instituto Politécnico de } \\
\text { Coimbra; Instituto Politécnico } \\
\text { de Lisboa; Instituto Politécnico } \\
\text { de Santarém; Instituto } \\
\text { Politécnico de Setúbal; } \\
\text { Instituto Politécnico de } \\
\text { Viana do Castelo; Instituto } \\
\text { Politécnico de Viseu; Escola } \\
\text { Superior de Enfermagem de } \\
\text { Lisboa }\end{array}$ & $\begin{array}{l}\text { Instituto Politécnico do Cávado e do } \\
\text { Ave; Escola Superior de Educação de } \\
\text { Castelo Branco; Instituto Superior } \\
\text { de Engenharia de Coimbra; Escola } \\
\text { Superior de Teatro e Cinema do } \\
\text { Instituto Politécnico de Lisboa; Escola } \\
\text { Superior de Educação do Instituto } \\
\text { Politécnico do Porto; Instituto } \\
\text { Politécnico de Setúbal; Instituto } \\
\text { Politécnico de Viana do Castelo; Escola } \\
\text { Superior de Enfermagem de Coimbra. }\end{array}$ & & \\
\hline $\begin{array}{l}\text { Escola Superior de Educação } \\
\text { Paula Frassinetti; Instituto } \\
\text { Superior de Ciências da } \\
\text { Administração; Instituto Superior } \\
\text { de Entre Douro e Vouga }\end{array}$ & $\begin{array}{l}\text { Instituto Superior de Tecnologias } \\
\text { Avançadas de Lisboa }\end{array}$ & & \\
\hline
\end{tabular}




\subsection{O enquadramento institucional da fraude académica}

Para analisar mais detalhadamente os documentos referenciados, definimos 4 categorias analíticas que pretendem dar conta do enquadramento institucional que as instituições do ensino superior concretizam no domínio da fraude e da integridade académicas. Assim, as referências diretas ou indiretas à fraude ou a formas de fraude foram enquadradas em 4 dimensões analíticas:

- Definição conceptual de fraude académica;

- Elaboração de estratégias para a sua prevenção;

- Estabelecimento de mecanismos de deteção de fraude académica;

- Configuração de sanções académicas e/ou disciplinares dos comportamentos fraudulentos.

Entre os documentos consultados, são raros aqueles que explicitamente e de forma inequívoca referem a questão da fraude académica em toda a sua extensão e complexidade, promovendo uma abordagem integrada. Isto é, promovendo uma abordagem que tenha em consideração a fraude académica não só na sua delimitação conceptual, mas também na definição de mecanismos de implementação de medidas de prevenção, de estratégias de deteção e, por fim, na definição de sanções a aplicar aos infratores. A análise documental permite-nos perceber que, para a maioria das instituições de ensino superior, a fraude académica é abordada focalizando-se apenas em uma ou duas das quatro dimensões em cima mencionadas. Tornase, por isso, relevante perceber se as instituições de ensino superior contribuem para fazer emergir estratégias integradas de combate à fraude académica ou se, ao invés, lhe respondem de forma fracionada.

No que respeita à definição de fraude académica, procurámos averiguar em que medida os diferentes documentos institucionais permitem referenciar distintas conceções de fraude, conceptualizando e 
operacionalizando o fenómeno de forma mais abrangente ou, pelo contrário, de forma mais restrita. Em concreto, procurou dar-se conta da presença nos documentos analisados de vários tipos de fraude, da gravidade atribuída, do estabelecimento de relações entre a gravidade e o tipo de sanções, da relevância conferida ao contexto da fraude (dentro ou fora da sala de aula) e das formas de responsabilização (diretas - quando se considera apenas quem comete fraude - ou também indiretas - quando se considera quem facilita ou viabiliza a fraude).

Atendendo a que a menção, explícita ou mesmo implícita, em documentos institucionais, à integridade e à fraude académica constitui, ela própria, uma estratégia de prevenção, importa observar os documentos institucionais no sentido de dar conta de estratégias ou medidas preventivas. Procurando saber, por exemplo, se os documentos mais gerais (como os estatutos) preveem regulamentação específica no domínio da defesa e da promoção da integridade académica; ou se são criados órgãos ou estruturas que visem intervir nesse domínio.

Os documentos institucionais que procedem a uma regulamentação específica das práticas das instituições de ensino superior (como, por exemplo, os regulamentos pedagógicos) permitem, por regra, identificar mecanismos institucionais de deteção de fraude. A consulta dos documentos selecionados procurou dar conta de medidas de deteção de fraude, preocupando-se igualmente em referenciar os domínios em que essas medidas operam. Por exemplo, preocupam-se com o uso das novas tecnologias no domínio da violação da integridade académica? Preveem o uso de software de deteção de plágio? Institucionalizam mecanismos de denúncia?

Por último, uma quarta dimensão relevante para escrutinar os documentos institucionais tem a ver com a previsão ou a existência de sanções. Designadamente, é relevante saber se existe ou não um quadro diferenciado de sanções; se as sanções se estendem ou não do âmbito académico ao âmbito disciplinar; se está ou não definido um 
quadro institucional de gestão das fraudes detetadas (quem avalia a gravidade, quem aplica as penas, quais os mecanismos de recurso, etc.).

\subsection{Comissões de ética}

As comissões de ética são instrumentos que, muito frequentemente, enquadram as questões relativas à fraude e à integridade académicas. Contudo, em Portugal, a existência deste tipo de comissões é marginal. Nos subsistemas politécnico público e universitário privado somente duas instituições divulgam publicamente a sua existência, explicitando as principais funções e as atividades dos respetivos conselhos ou comissões de ética. Nomeadamente, a Escola Superior de Tecnologias da Saúde do Instituto Politécnico de Lisboa e a Universidade Fernando Pessoa. Já para o subsistema universitário público pudemos referenciar e analisar os documentos enquadradores das comissões de ética e deontologia da Universidade de Aveiro; da Universidade do Minho; da Universidade do Porto; da Universidade de Trás-os-Montes e Alto Douro; e do ISCTE- IUL. De referir que, apesar de não ter uma comissão de ética, o ISEG-UTL tem uma estrutura - Observatório Pedagógico - que desempenha funções de monitorização das metodologias de intervenção pedagógica, reportando aos Conselhos Científico e Pedagógico do ISEG, e encontrando-se em estreita articulação com alguns dos serviços tutelados pelo Conselho Diretivo. A sua missão não se aproxima das funções normalmente atribuídas às comissões de ética.

As comissões de ética são organismos que funcionam como órgão colegial, multidisciplinar e independente, ocupando-se da promoção de padrões éticos em todas as atividades académicas (docência, investigação e atividades de extensão, incluindo prestação de serviços à comunidade e divulgação da ciência) das diversas unidades da instituição de ensino e na conduta dos seus membros (docentes, funcionários 
ou estudantes). Nessa medida, são um instrumento fundamental de defesa e de promoção dos princípios que pautam as condutas definidoras da integridade académica. Ressalva-se o facto de a maioria das comissões de ética centrar as suas ações nas questões éticas relativas à investigação clínica e à ética na investigação experimental com animais, estando, por isso, tendencialmente circunscritas a instituições e unidades orgânicas que atuam na área da saúde. Compete-lhes regular o funcionamento da atividade laboratorial e clínica e a conduta dos docentes, estudantes e investigadores. Contudo, a ação das comissões de ética não se esgota aí, considerando não só as questões éticas relacionadas com a investigação, nomeadamente na área das "biociências", mas também sobre eventuais casos de fraude académica protagonizados por estudantes, docentes ou investigadores, ou mesmo sobre "questões comportamentais", como "excessos de praxes académicas e assédio de diversos tipos" (Universidade do Minho). Compete-lhes ainda acompanhar os projetos de investigação que acolhem, sobretudo aqueles que envolvam questões sensíveis, nomeadamente, aqueles que incluam (sob qualquer forma) pessoas, animais ou material biológico proveniente de pessoas ou animais, além daqueles que são específicos às ciências sociais e humanas, às tecnologias e às artes (Universidade do Porto).

Em algumas instituições, este órgão assume a missão de zelar pela observância e promoção de padrões de integridade, honestidade e responsabilidade na atividade das unidades de ensino e de investigação nas suas relações internas e externas, bem como na conduta dos seus membros (UTAD). Assim, são organismos que se manifestam sobre questões éticas suscitadas nas áreas do ensino, da investigação científica, da prestação de serviços à comunidade e do funcionamento da instituição (ISCTE-IUL). Estes organismos, bem como os seus membros, estão ainda intimamente ligados à planificação e execução de códigos de conduta e de boas práticas. Deste trabalho específico resultam documentos, regulamentos e recomendações que são disponibilizados a toda a comunidade académica. 
São ainda organismos constituídos por membros internos e externos às instituições, que integram docentes e não docentes, que têm como missão promover a reflexão e contribuir para a definição das diretrizes adequadas ao estabelecimento e consolidação de uma política de salvaguarda de princípios éticos e deontológicos, designadamente emitindo pareceres, quando tal thes for solicitado, ou propondo, por iniciativa própria, a adoção de códigos de conduta (Universidade de Aveiro). Algumas comissões de ética são organizadas em subcomissões, podendo integrar um ou mais elementos por unidade orgânica (Universidade do Porto). No caso da Universidade do Porto, cabe ainda a este órgão divulgar estudos científicos sobre fraude académica, relatórios finais de conferências internacionais sobre o tema em análise, bem como as principais diretrizes internacionais sobre o mesmo tema. No exercício das suas funções atuam com total independência relativamente aos órgãos de governo da instituição de ensino (ISCTE-IUL).

\subsection{Códigos de conduta}

Não existindo qualquer imposição legal que imponha este tipo de instrumento, ainda assim, algumas instituições de ensino superior têm vindo a adotar códigos de conduta e de boas práticas, sendo estes consentidos, e diríamos incentivados, pelo disposto no $\mathrm{n}^{\circ} 7$ do artigo $9^{\circ}$ do RJIES. Entre as instituições que dispõem deste tipo de instrumento de defesa e de promoção da integridade académica encontram-se 5 instituições universitárias e 1 instituição de ensino politécnico, possuindo todas elas um código de conduta e/ou de boas práticas no qual se enquadra a atuação dos estudantes em contexto académico (2011) ${ }^{25}$.

25 Referimo-nos concretamente à Universidade da Madeira; ao ISCTE-IUL; à Universidade Técnica de Lisboa; à Universidade de Aveiro (carta de conduta dos estudantes da Universidade de Aveiro); à Universidade do Porto; e ao Instituto Superior de Administração e Gestão. 
Apesar de numericamente menos expressivos comparativamente aos demais tipos de documentos que enquadram a fraude e a integridade académicas, os códigos de conduta e de boas práticas são muito relevantes, na medida em que fixam e desenvolvem padrões comportamentais que pretendem nortear a integridade académica (ainda que tendam a centrar-se nos estudantes). Entre os anos 2011 (quando iniciámos esta pesquisa) e 2013, uma instituição (Universidade do Minho) elaborou um novo código de conduta e de boas práticas.

Não se circunscrevendo exclusivamente à fraude académica, os códigos de conduta e de boas práticas estabelecem um conjunto de princípios e de normas que devem conduzir os comportamentos dos funcionários, dos professores e dos estudantes. Enquadram e orientam também a missão das instituições nos processos de ensino-aprendizagem, de formação e de investigação científica, em concordância com a lei geral e com os estatutos das instituições e demais regulamentos e legislação aplicável. Nessa medida, são um instrumento de operacionalização de princípios mais gerais, e frequentemente imprecisos, relativos à integridade académica. Os códigos de conduta e de boas práticas consultados têm, portanto, um espetro alargado de destinatários, incluindo como alvo das suas normas, além dos estudantes, os docentes, os investigadores e restantes trabalhadores não docentes e não investigadores das instituições de ensino superior. Deste modo, os códigos de conduta integram uma visão de responsabilidade e de conduta partilhada entre os estudantes, a restante comunidade académica e as próprias escolas/departamentos/faculdades e/ou universidades nas questões relacionadas com a integridade académica. São exemplos os códigos de conduta da Universidade Técnica de Lisboa (2009); da Universidade do Porto (2010); da Universidade da Madeira (2010); da Universidade do Minho (2012); do ISCTE-IUL (2008); e da Universidade de Aveiro (2008). Note-se que há aqui um claro efeito do RJIES (promulgado em 2007) na emergência deste tipo de documentos. 
Outros códigos igualmente referenciados e analisados referem-se às normas que devem ser seguidas exclusivamente pelos trabalhadores que exercem funções nas respetivas instituições. São exemplos os códigos de conduta do Instituto Politécnico de Lisboa e do Instituto Politécnico de Portalegre. Outras instituições, além destes códigos de conduta, elaboraram documentos exclusivamente orientados para tratar da questão da fraude académica entre estudantes, como, por exemplo, a Universidade de Aveiro (Carta de conduta dos estudantes da Universidade de Aveiro) e a Universidade da Madeira (Despacho $n^{\circ}$ 140/R/2009 - Deteção de Plágio).

Enquanto instrumentos que visam regular comportamentos concretos da comunidade académica, a generalidade dos documentos consultados revela insuficiências nítidas em matéria de regulamentação de medidas preventivas da fraude académica. Além disso, são também visíveis diferenças interinstitucionais sobre o que é considerado um comportamento íntegro, bem como sobre as medidas a adotar para a sua prevenção, deteção e punição. A operacionalização das políticas institucionais definidas nos códigos de conduta analisados é limitada e carece da previsão de organismos capazes de fomentar uma política integrada de promoção e de defesa da integridade académica, a exemplo daquele (o academic conduct officer) que é anunciado neste livro por Jude Carroll. A ausência desse tipo de organismos hipoteca a consistência das respostas produzidas em casos de fraude académica, prejudicando a equidade de tratamento. O que ocorre tendencialmente, quando, como parece ser o caso, este tipo de documentos são elaborados sob a perspetiva da sua autossuficiência é converterem-se em letra morta da instituição ou gerarem formas muito díspares de uso dentro da própria instituição, dificultando a consolidação de uma política institucional.

O desenvolvimento de distintas conceções de fraude académica e do que é um comportamento fraudulento no seio da comunidade académica, e sobretudo as formas como esse comportamento é enfrentado 
dentro de cada instituição, acaba por sujeitar a cultura da integridade académica a circunstancialismos organizacionais e a modelos pedagógicos ancorados em opções pessoais e diferenciadas. Neste contexto, o enquadramento dos comportamentos fraudulentos é altamente permeável à subjetividade de quem os avalia, produzindo-se frequentemente respostas particulares e que dependem da interpretação de cada unidade orgânica, departamento ou escola e, muitas vezes, em última instância, de quem lidera. Estas prováveis diferentes interpretações introduzem subjetividade sobretudo na definição das medidas de prevenção e das sanções académicas e/ou disciplinares a aplicar em caso de fraude académica. Convem referir relativamente às atitudes disciplinares, que o artigo ${ }^{\circ} 75$ do Regime Jurídico das Instituições do Ensino Superior concede autonomia disciplinar às instituições de ensino superior públicas, significando que cada instituição tem a capacidade de punir estudantes, docentes, investigadores e outros funcionários com algum grau de autonomia. No que concerne aos estudantes, o disposto nos $\mathrm{n}^{\circ} \mathrm{s} 4,5$ e 6 do referido artigo rege tal poder disciplinar, também abrangido por estatutos e regulamentos próprios das diversas unidades orgânicas das universidades, com aplicação subsidiária do estatuto disciplinar dos trabalhadores da função pública, aplicável aos docentes e investigadores da instituição. Esta solução, num quadro de ausência de instrumentos mais operacionais - como, por exemplo, apesar das suas limitações, são os códigos de conduta - poderá resultar numa aplicação inconsistente das políticas institucionais e num tratamento diferenciado dos estudantes.

Sendo estes instrumentos aqueles que mais concretizam uma política institucional vale a pena promover uma análise mais detalhada dos códigos de conduta. Fazemos esse exercício, de forma esquemática, na Tabela 3, partindo das 4 dimensões analíticas a que recorremos para recolher e caracterizar os documentos que enquadram a questão da fraude e da integridade académicas nas instituições de ensino superior portuguesas. Desenvolvemos posteriormente uma abordagem mais detalhada desse tipo de documentos. 
TABELA 3 - CÓDIGOS DE CONDUTA E DE BOAS PRÁTICAS CONSULTADOS POR INSTITUIÇÃO DE ENSINO SUPERIOR

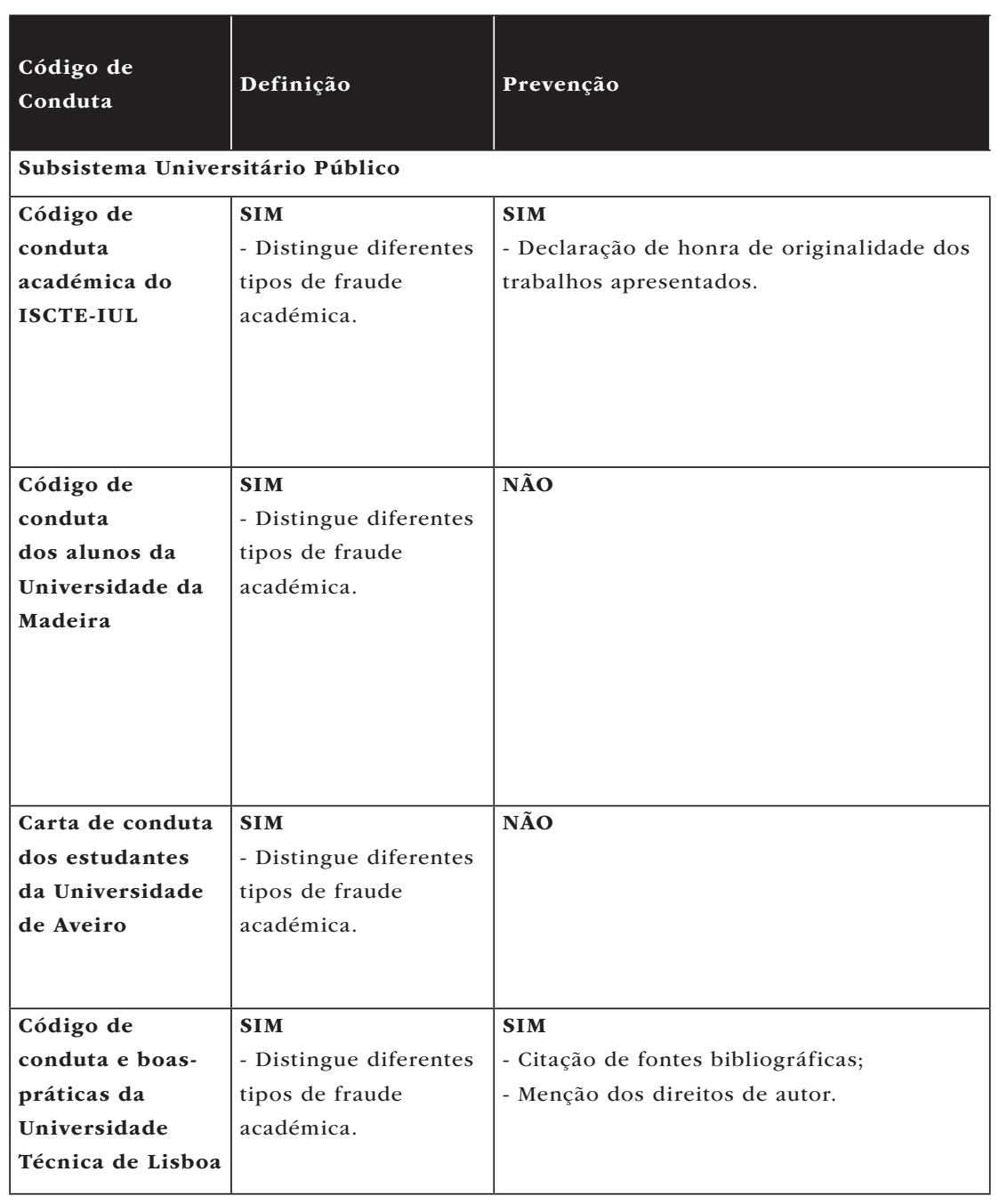




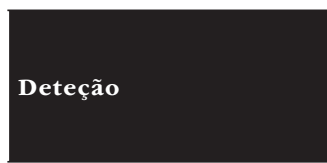

\section{\begin{tabular}{|l|l}
\hline Documentos & Documents
\end{tabular} Sanção \\ complementares \\ (que referem a questão da \\ fraude académica)}

\begin{tabular}{|c|c|c|}
\hline $\begin{array}{l}\text { SIM } \\
\text { - Utilização de software } \\
\text { antiplágio. }\end{array}$ & $\begin{array}{l}\text { SIM } \\
\text { - Remete para o regulamento } \\
\text { disciplinar dos discentes do } \\
\text { ISCTE; } \\
\text { - Contudo, enquadra as } \\
\text { sanções entre a advertência e } \\
\text { a interdição da frequência de } \\
\text { cursos do ISCTE. }\end{array}$ & $\begin{array}{l}\text { - Despacho reitor - Plágio; } \\
\text { - Regulamento disciplinar; } \\
\text { - Regulamento de avaliação; } \\
\text { - Estatutos. }\end{array}$ \\
\hline $\begin{array}{l}\text { SIM } \\
\text { - Utilização de software } \\
\text { antiplágio; } \\
\text { - Enuncia o dever que } \\
\text { cada um dos membros } \\
\text { da comunidade } \\
\text { académica tem de } \\
\text { comunicar todas as } \\
\text { possíveis infrações } \\
\text { cometidas por terceiros. }\end{array}$ & NÃo & $\begin{array}{l}\text { - Regulamento de avaliação } \\
\text { dos alunos; } \\
\text { - Regulamento disciplinar dos } \\
\text { alunos; } \\
\text { - Despacho no 140/R/2009 } \\
\text { deteção de plágio. }\end{array}$ \\
\hline NÃo & $\begin{array}{l}\text { - Remete para o regulamento } \\
\text { disciplinar dos discentes; } \\
\text { - Contudo, enquadra as } \\
\text { sanções entre a advertência e } \\
\text { a interdição da frequência de } \\
\text { cursos do UA. }\end{array}$ & NÃO \\
\hline NÃO & NÃo & $\begin{array}{l}\text { - Código de conduta; } \\
\text { - Regulamento disciplinar. }\end{array}$ \\
\hline
\end{tabular}


TABELA 3 - CÓdigos dE CONDUTA E DE BOAS PRÁTICAS CONSULTADOS POR INSTITUIÇÃO DE ENSINO SUPERIOR (CONT.)

\begin{tabular}{|c|c|c|}
\hline $\begin{array}{l}\text { Código de } \\
\text { Conduta }\end{array}$ & Definição & Prevenção \\
\hline $\begin{array}{l}\text { Universidade } \\
\text { e Integridade } \\
\text { Académica - } \\
\text { Universidade do } \\
\text { Porto }\end{array}$ & $\begin{array}{l}\text { SIM } \\
\text { - Distingue diferentes } \\
\text { tipos de fraude } \\
\text { académica }\end{array}$ & $\begin{array}{l}\text { SIM } \\
\text { - Remete para a necessidade de se } \\
\text { difundirem princípios éticos reguladores; } \\
\text { - Implementação de medidas que vão } \\
\text { para além do aspeto punitivo, sendo esta } \\
\text { uma tarefa inalienável dos seniores ou } \\
\text { responsáveis das unidades. }\end{array}$ \\
\hline $\begin{array}{l}\text { Código de } \\
\text { conduta } \\
\text { ética da } \\
\text { Universidade do } \\
\text { Minho (2012) }\end{array}$ & $\begin{array}{l}\text { SIM } \\
\text { Distingue diferentes } \\
\text { tipos de fraude } \\
\text { académica. }\end{array}$ & NÃo \\
\hline \multicolumn{3}{|c|}{ Subsistema Politécnico Privado } \\
\hline $\begin{array}{l}\text { Código de } \\
\text { boa conduta } \\
\text { académica do } \\
\text { ISAG }\end{array}$ & $\begin{array}{l}\text { SIM } \\
\text { Distingue diferentes } \\
\text { tipos de fraude. } \\
\text { Diferencia diferentes } \\
\text { graus de gravidade } \\
\text { da fraude académica } \\
\text { propondo diferentes } \\
\text { sanções conforme o tipo } \\
\text { de fraude em causa. } \\
\text { Particular destaque ao } \\
\text { plágio. }\end{array}$ & NÃO \\
\hline
\end{tabular}




\begin{tabular}{|c|c|c|}
\hline Deteção & Sanção & $\begin{array}{l}\text { Documentos } \\
\text { complementares } \\
\text { (que referem a questão da } \\
\text { fraude académica) }\end{array}$ \\
\hline NÃO & $\begin{array}{l}\text { SIM } \\
\text { - Remete para o regulamento } \\
\text { disciplinar } \\
\text { e eventualmente } \\
\text { consequências a nível penal. }\end{array}$ & $\begin{array}{l}\text { - Carta de Direitos e Deveres } \\
\text { da Comunidade Académica da } \\
\text { Universidade do Porto; } \\
\text { - Alteração do "Regulamento } \\
\text { geral para avaliação dos } \\
\text { discentes de primeiros } \\
\text { ciclos, de ciclos de estudos } \\
\text { integrados de mestrado e de } \\
\text { segundos ciclos da UPorto"; } \\
\text { - Regulamento de Avaliação } \\
\text { aplicável aos primeiros ciclos, } \\
\text { segundos ciclos e cursos de } \\
\text { doutoramento ( } 1^{\circ} \text { ano dos } \\
\text { terceiros ciclos) da FLUP, a } \\
\text { partir do ano letivo } 2010 / 2011 .\end{array}$ \\
\hline NÃO & $\begin{array}{l}\text { SIM } \\
\text { - Quanto à aplicação } \\
\text { das sanções, o presente } \\
\text { documento remete para a } \\
\text { lei geral, bem como para } \\
\text { o regulamento disciplinar } \\
\text { do estudante e demais } \\
\text { regulamentos pertinentes. }\end{array}$ & $\begin{array}{l}\text { - Regulamento disciplinar do } \\
\text { estudante; } \\
\text { - Regulamento sobre } \\
\text { Inscrições, Avaliação e } \\
\text { Passagem de Ano. }\end{array}$ \\
\hline NÃO & $\begin{array}{l}\text { SIM } \\
\text { - Anulação do trabalho em } \\
\text { causa, com consequente } \\
\text { reprovação na unidade } \\
\text { curricular, ficando o registo } \\
\text { do motivo da reprovação, } \\
\text { sem prejuízo de outras } \\
\text { consequências de natureza } \\
\text { disciplinar e criminal, face ao } \\
\text { grau de plágio detetado. }\end{array}$ & NÃO \\
\hline
\end{tabular}


TABELA 3 - CÓdIGOS DE CONDUTA E DE BOAS PRÁTICAS CONSULTADOS POR INSTITUIÇÃO DE ENSINO SUPERIOR (CONT.)

\begin{tabular}{|l|l|l|}
\hline $\begin{array}{l}\text { Código de } \\
\text { Conduta }\end{array}$ & Prefinição & \\
\hline \multicolumn{2}{|l|}{ Subsisão } \\
\hline $\begin{array}{l}\text { Código de } \\
\text { conduta do } \\
\text { IPL - Instituto } \\
\text { Politécnico de } \\
\text { Lisboa }\end{array}$ & NÃo & NÃO \\
\hline $\begin{array}{l}\text { Código de ética } \\
\text { do IPP - Instituto } \\
\text { Politécnico de } \\
\text { Portalegre }\end{array}$ & NÃO & NÃO \\
\hline
\end{tabular}

\subsection{Um olhar mais detalhado sobre os códigos de conduta}

O código de conduta do Instituto Superior das Ciências do Trabalho e da Empresa do Instituto Universitário de Lisboa (2008) refere que é expectável que os estudantes não cometam ilícitos académicos que evidenciem comportamentos fraudulentos (cópia em exame ou/e plágio), nomeadamente:

"A consulta de suportes ou recursos não autorizados pelo docente durante a realização de uma prova ou exame; cometam plágio ou práticas associadas à utilização ou reprodução de material não devidamente atribuído ao autor original, cumprindo escrupulosamente os princípios de honestidade 


\begin{tabular}{|c|c|c|}
\hline Deteção & Sanção & $\begin{array}{l}\text { Documentos } \\
\text { complementares } \\
\text { (que referem a questão da } \\
\text { fraude académica) }\end{array}$ \\
\hline NÃo & NÃO & $\begin{array}{l}\text { SIM } \\
\text { - Regulamento de avaliação } \\
\text { e frequência dos cursos do } \\
1^{\circ} \text { ciclo Escola Superior de } \\
\text { Educação - IPL; } \\
\text { - Regulamento de Avaliação } \\
\text { do Aproveitamento dos } \\
\text { Estudantes } 2010 / 2011 \text { - Escola } \\
\text { Superior de Tecnologia da } \\
\text { Saúde de Lisboa. }\end{array}$ \\
\hline NÃO & NÃO & NÃO \\
\hline
\end{tabular}

académica que o proíbem; esta disposição aplica-se a todo o tipo de trabalhos académicos (fichas de leitura, ensaios intercalares ou finais, exercícios em aula, testes, projetos de fim de curso, exames e dissertações)". [Sendo que por plágio, entende-se] “(...) a utilização de ideias, frases, parágrafos ou textos completos de outros colegas ou autores sem citar e creditar as respetivas fontes".

Outro instrumento produzido pelo ISCTE e que complementa a informação do Código de Conduta Académica do ISCTE-IUL é o despacho $n^{\circ} 45 / 2012$ do Reitor do ISCTE/IUL onde, além de se definir o que se entende por fraude académica, se definem mecanismos de prevenção e de deteção da fraude académica. Faz parte da estratégia 
de prevenção da fraude académica a obrigatoriedade de assinar uma declaração de compromisso de honra que confirme a autoria dos trabalhos académicos. Como mecanismo de prevenção e deteção, o ISCTE definiu ainda a utilização de software de deteção de plágio para os trabalhos produzidos pelos estudantes.

Quanto aos procedimentos disciplinares, refere-se que as sanções são definidas segundo o regulamento disciplinar do ISCTE-IUL, podendo variar entre a advertência e a interdição da frequência de atividades escolares no ISCTE.

A Carta de Conduta dos Estudantes da Universidade de Aveiro (2008) destina-se exclusivamente aos estudantes da mesma universidade, incidindo no dever de os estudantes não cometerem comportamentos fraudulentos, entre os quais: "Não recorrer à utilização de cábulas, plágio, fraude ou de materiais e de práticas não permitidas pelo docente no contexto do trabalho académico".

A regulamentação apenas define o conceito de fraude académica, não prevendo medidas para a sua prevenção ou deteção.

O código de conduta da Universidade Técnica de Lisboa (2009), que entretanto se fundiu com a Universidade de Lisboa, incide especialmente em duas das dimensões analíticas consideradas anteriormente. Foca, com particular detalhe, as questões relacionadas com a definição do conceito mas também incide nos mecanismos de prevenção da fraude académica para o contexto institucional. Considera-se fraude académica as seguintes situações:

"A apresentação seletiva de resultados, para publicação ou não, com omissão voluntária de resultados indesejáveis; A interpretação de resultados de investigação negligente ou deliberadamente falsa; A distorção intencional de métodos, nomeadamente métodos estatísticos, de forma a chegar a conclusões diferentes daquelas que os dados justificam; A 
apresentação como coautor de artigos ou de qualquer outra criação intelectual para os quais não tenha contribuído significativamente; A omissão de publicação de nomes de coautores ou então a inserção como coautores de quem não tenha contribuído.”

Esta linguagem, relativamente à referida para as duas instituições anteriores, dirige-se mais àqueles que estão envolvidos em formação pós-graduada e abrange também, de forma mais explícita, os universos da pesquisa científica e da docência. O documento confere especial relevância a dois tipos distintos de comportamentos, sendo ambos considerados fraudulentos: o plágio e a usurpação de criações intelectuais.

Assim, o plágio é definido do seguinte modo:

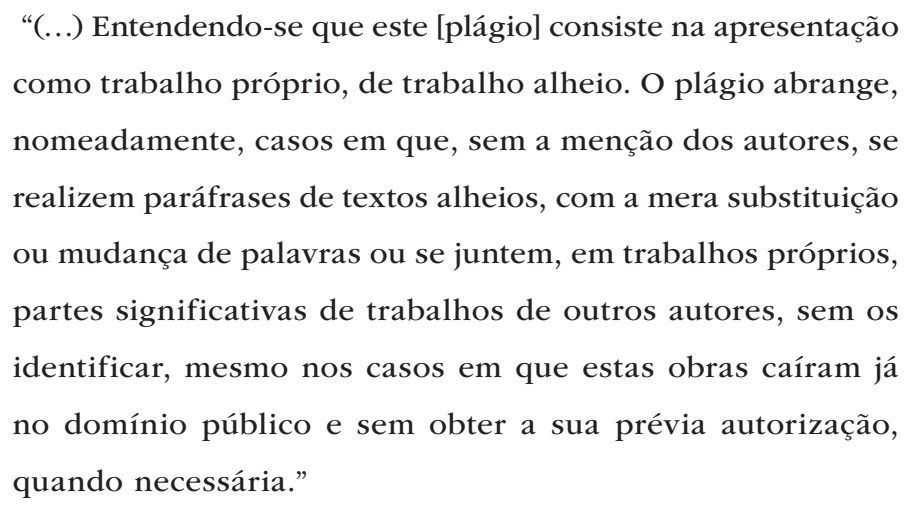

Distingue-se ainda, dentro da categoria de plágio, diferentes modos de incorrer neste comportamento fraudulento:

"A realização de atos de auto plágio, entendendo-se que este consiste na apresentação repetida do mesmo trabalho ou de porções importantes de trabalhos anteriores sem a adição de material significativamente novo feito com o propósito de o fazer passar como trabalho novo e original." 
A definição de fraude académica inclui ainda a usurpação de criações intelectuais:

\begin{abstract}
"A usurpação de criações intelectuais, entendendo-se esta pela utilização de criação intelectual alheia, sem prévia autorização do respetivo autor quando necessária por força de lei ou de convenção. Considera-se, designadamente, usurpação, a apropriação ilegítima de dados, de software ou de todas as demais criações intelectuais protegidas por propriedade intelectual mesmo que o usurpador não retire ou não vise retirar dessa apropriação qualquer vantagem económica, própria ou alheia. Consideram-se ainda abrangidas pela usurpação, todos os procedimentos, mesmo que na forma tentada, intencionalmente destinados a eliminar medidas legítimas de proteção de criações intelectuais protegidas por propriedade intelectual."
\end{abstract}

Este código de conduta exemplifica também quais os procedimentos a adotar para assegurar a ocorrência de comportamentos não fraudulentos (mecanismos de prevenção), exclusivamente no que diz respeito ao plágio. Assim, as boas práticas para salvaguarda da boa conduta do trabalho científico e no ensino assentam nos princípios seguintes:

"A citação das fontes usadas na elaboração de um trabalho deve ser rigorosa e exaustiva; Os direitos de autor tanto sobre as fontes usadas como sobre as discussões, debates, etc., que contribuíram para o trabalho final devem ser mencionados [...]" [destaque nosso].

O código de conduta da Universidade do Porto (2010) intitula-se "Universidade e Integridade Académica" e foi o documento mais 
completo encontrado durante a análise documental, sobre a questão em análise. Além de definir o conceito de fraude, tipificando as suas configurações, atribui diferentes graus de gravidade consoante o nível de ensino (pré-graduado ou pós-graduado) em que o aluno se encontra:

\begin{abstract}
"O muito banalizado recurso à "cópia" durante exames escritos (a partir de outros examinandos, ou de elementos furtivamente consultados, escritos ou obtidos por comunicação telefónica) enfileira ao lado da inclusão de textos ou fragmentos de outros autores, sem indicação da fonte consultada, em trabalhos escritos, apresentados a nível de pré-graduação ou, mais gravosamente ainda, de pós-graduação (mesmo em dissertações de mestrado ou de doutoramento) [destaque nosso].
\end{abstract}

A tónica incide ainda na necessidade da aplicação de medidas não só de deteção como de prevenção de fraude académica.

“ (...) É por isso vital que, a par das medidas disciplinares que a deteção do plágio possa suscitar (nos casos em que é detectado, provavelmente minoritários), se envidem todos os esforços para explicar, difundir e enunciar princípios éticos e ideais reguladores que configurem o insistente apelo para um comportamento responsável, até porque nem sempre os prevaricadores estão cônscios do alcance e gravidade destas práticas".

(...) Também aqui, como se fez notar a propósito do plágio, é indispensável ir além do aspeto punitivo (de que a desqualificação do(s) culpados(s) é mais significativa do que a cassação de graus ou títulos ou até a expulsão da instituição) para dar particular ênfase à difusão e ensino de princípios éticos reguladores, mormente na fase de formação dos jovens investigadores." 
Outro dos fatores diferenciadores deste documento em relação aos restantes diz respeito à explícita ampliação da responsabilização de toda a comunidade académica na prevenção da fraude:

\begin{abstract}
"Esta é uma tarefa inalienável dos seniores ou responsáveis das unidades: criar um meio que promova a conduta responsável e correta, vigiar e corrigir, dar o exemplo de honestidade intelectual e evitar comportamentos que, embora não sancionáveis, são eticamente reprováveis (tais como a inclusão na lista dos autores de um trabalho do nome de quem não teve interferência na respectiva elaboração).”
\end{abstract}

O código de conduta da universidade da Madeira (2010) apresenta, replicando em boa parte o código do ISCTE, uma definição bastante exaustiva do que é considerado fraude académica no que diz respeito ao comportamento dos estudantes. Considera-se fraude académica: praticar a cópia, o plágio ou de qualquer outro modo submeter de forma desonesta um trabalho para avaliação, incluindo, mas não se limitando a:

“i) Utilizar ou tentar utilizar materiais ou fontes não autorizadas em momentos de avaliação;

ii) Apropriar -se de textos, ideias, dados, ilustrações ou informação de outras fontes ou pessoas e apresentá-los como sendo seus;

iii) Forjar, falsificar, distorcer, escolher seletivamente ou omitir dados, resultados ou fontes nos seus relatórios, ensaios, monografias, teses ou outros trabalhos escritos;

iv) Comprar ou vender relatórios, ensaios, monografias, dissertações, teses ou outros trabalhos para uso fraudulento.

c) Aceder, ou tentar aceder, sem a devida autorização, qualquer que seja o fim, a material didáctico ou documentos oficiais da Universidade, tais como: 
i) Enunciados e resolução das provas de avaliação;

ii) Pautas, registos académicos ou histórico escolar;

iii) Documentos de trabalho e correspondência, independentemente da natureza do seu suporte, dos órgãos de gestão e representação da Universidade.

d) Fornecer informação falsa nos formulários e documentos da Universidade.

e) Utilizar o material informático para fins não autorizados, tais como:

i) Violações dos direitos de propriedade intelectual e de autor;

ii) Acesso ou tentativa de acesso não autorizado a sistemas informáticos;

iii) Alteração, manipulação, cópia ou destruição de dados informáticos, ainda que na forma tentada.

f) Transmitir a outrem o cartão universitário ou obter, com falsos pretextos, cópias do cartão.

g) Ordenar, ajudar ou ocultar, ainda que na forma tentada, atos de fraude académica.”

Um aspeto interessante que diz respeito ao regime disciplinar que regulamenta os procedimentos, em caso de violação ao código, refere o dever que cada um dos membros da comunidade académica tem de comunicar as possíveis infrações cometidas por terceiros, enquanto estratégia de deteção de fraude académica.

Por fim, o código de conduta mais recentemente elaborado no subsistema universitário público foi o da universidade do Minho (2012), onde se estabelecem quais os procedimentos que protegem a integridade do processo de avaliação de conhecimentos, salientando os seguintes:

“a) A utilização de cábulas, notas, textos, ou outros elementos não autorizados na prestação das provas; 
b) $\mathrm{O}$ ato de copiar o trabalho, ou parte dele, de outra pessoa ou permitir que outra pessoa copie o seu trabalho, ou parte dele, em provas de avaliação;

c) O recurso ao apoio de outra(s) pessoa(s), presente(s) no espaço do exame ou fora dele, à revelia das regras estabelecidas para o método de avaliação;

d) A assinatura, com o nome de outra pessoa, nomeadamente em testes, exames ou trabalhos sujeitos a avaliação;

e) A posse indevida, antes da prova de avaliação, de formulários, questionários ou outros elementos constantes da mesma prova de avaliação;

f) A utilização de meios tecnológicos não autorizados, capazes de facilitar o acesso a informação relevante para os exames ou outras provas de avaliação, em proveito próprio ou em benefício de outrem."

O plágio é tido em particular atenção, tal como noutros documentos regulamentares sendo um comportamento que merece distinção dos restantes tipos de fraude académica.

"Entende-se por prática de plágio quaisquer situações em que se usam ideias, afirmações, dados, imagens, ou ilustrações de outro(s) autor(es), sem o adequado reconhecimento explícito desse(s) autor(es). Consideram-se, assim, situações de fraude por plágio de um trabalho literário, artístico ou científico, adotando a forma de relatório, artigo, ensaio, tese ou dissertação, em formato de papel ou digital, no todo ou em parte, as que a seguir se explicitam, de modo não exaustivo:

a) A submissão de trabalho supostamente pessoal e original, elaborado total ou parcialmente por outrem, sem o respeito pelas normas de citação e referenciação bibliográfica de identificação do autor ou autores; 
b) A utilização incorreta de ideias ou de paráfrases do trabalho de outrem, quer pela sua extensão ou repetição abusiva de palavras e conteúdos, quer pela ausência de uma correta identificação dos seus autores;

c) A apresentação, como sendo trabalho original, de um trabalho que já haja sido por si apresentado ou publicado noutra ocasião, sem do facto se dar conhecimento explícito;

d) A apresentação de trabalho feito em conluio com outra pessoa, resultante de colaboração não autorizada."

São ainda definidas outras situações de fraude académica:

“a) A apresentação de trabalhos, ensaios, relatórios, teses ou dissertações com resultados falsificados, fabricados ou tendenciosamente interpretados;

b) A destruição ou alteração de trabalhos de outrem, em proveito próprio;

c) A compra ou venda, no todo ou em parte, de dissertações, teses, relatórios ou outros trabalhos académicos, utilizados em processos de avaliação;

d) A falsificação de informação em formulários ou outros documentos oficiais.”

São referidas algumas diligências a ser tomadas em caso de fraude académica, com o intuito de sancionar as práticas fraudulentas. Contudo, não se faz referência às medidas concretas que se devem aplicar, deixando estes procedimentos para outros regulamentos como, por exemplo, o regulamento disciplinar:

"Sem prejuízo de não se limitarem as violações ou infrações aos casos explicitados, fica ainda a advertência de que, em geral, qualquer ato desonesto e fraudulento que seja praticado 
para benefício direto ou indireto do infrator ou infratores, deverá ser considerado violação da integridade académica e sujeito a procedimentos sancionatórios".

São, além de definidas as situações consideradas de fraude académica, definidas quais as sanções que devem ser aplicadas.

\begin{abstract}
"As sanções disciplinares por atos de conduta académica ilícita, bem como a definição e regulamentação dos procedimentos a adotar, serão tratados em conformidade com a lei geral, com o regulamento disciplinar do estudante e demais regulamentos pertinentes".
\end{abstract}

No subsistema politécnico privado, o ISAG, através do seu código de boa conduta académica, define os princípios éticos e boas práticas nos trabalhos académicos e investigação. Dá-se particular destaque aos comportamentos de plágio e falsificação de resultados, sendo que estes comportamentos são considerados uma violação da propriedade intelectual.

Como consequências, são enunciadas medidas concretas sancionatórias nos casos onde se detetem comportamentos fraudulentos, não havendo qualquer referência aos mecanismos de prevenção ou deteção da fraude.

\title{
8.8. Considerações finais
}

As preocupações relativas à fraude e à integridade académicas estão dispersas por vários tipos de documentos institucionais. Esse é desde logo um indicador da diversidade de formas de enquadrar estas questões. Da ausência completa de referências a esse tipo de questões, passando pela sua enunciação genérica nos estatutos das 
instituições, e chegando até à sua inscrição específica nos códigos de conduta, a integridade e a fraude conhecem graus muito diferenciados em termos da importância que assumem na configuração das políticas institucionais.

É sobretudo no subsistema universitário público que a regulamentação da fraude e das questões relativas à integridade académica assume particular evidência. Isso é tanto mais verdade quanto deixamos as abordagens mais genéricas e circunstanciais para olharmos os documentos que se focam especificamente na fraude e na integridade académica. Sendo também verdade que o RJIES, ao incluir no seu articulado a proposta de regulamentação das boas práticas, fomentou a elaboração de documentos centrados nas questões da fraude e da integridade académicas. Na sequência da sua promulgação, em 2007, várias instituições universitárias públicas têm vindo a elaborar códigos de conduta e de boas práticas.

Além dos códigos de conduta e de boas práticas, as comissões de ética (particularmente concentradas nas instituições da área da saúde) e os regulamentos (regulamentos académicos e pedagógicos; regulamentos disciplinares dos estudantes; regulamentos do funcionamento dos cursos; e regulamentos de avaliação) estendem, além das preocupações plasmadas nos estatutos, quando elas existem, a agenda da fraude e da integridade para um plano de maior operacionalidade. Ainda assim, é muito nítido que quanto mais se sai dos documentos com pendor mais genérico para os que promovem uma abordagem focada na fraude e na integridade académicas, mais estas deixam de ser encaradas numa perspetiva que tende a restringi-las ao plágio e aos estudantes, para passarem a ser olhadas de um modo mais abrangente, abarcando também docentes e funcionários e considerando outras dimensões da fraude e da integridade além do mero plágio.

Ainda que sejam numerosos os documentos institucionais que referenciámos por se reportarem às questões da fraude e da integridade, 
são muito poucas as instituições que dispõem de instrumentos regulamentares concretos, designadamente códigos de conduta. Mesmo estes instrumentos regulamentares mais operativos carecem de uma abordagem mais abrangente e, sobretudo, de um nível de maior instrumentalização. Muitos deles encerram preocupações que raramente vão além do plágio. Vários não preveem sanções ou remetem a sua concretização para outros regulamentos (disciplinares, de avaliação, de frequência, etc.) que não existem ou que não preceituam. Nenhum deles cria organismos reais que concretizem uma política institucional integrada de combate à fraude. Embora a prevenção da fraude seja algo que não se regulamenta, a verdade é que uma política eficaz de combate à fraude e de promoção da integridade não pode abdicar da dimensão da prevenção, sendo sintomático que essa dimensão esteja ausente dos códigos de conduta.

\subsection{Referências bibliográficas}

Almeida, F; Gama, P. e Peixoto, P. (2010), "La ética de los alumnos de la enseñanza superior: un estudio exploratorio sobre el fraude académico en Portugal”. Coimbra: Centro de Estudos Sociais. Oficina do CES, $\mathrm{n}^{\circ} 348,18 \mathrm{p}$.

Almeida, F.; Seixas, A.; Gama, P. e Peixoto, P. (2015), A Fraude Académica no Ensino Superior em Portugal - um estudo sobre a ética dos alunos portugueses. Coimbra: Imprensa da Universidade de Coimbra.

Bergadaà, M. (2015), Le plagiat académique. Compreendre pour agir. Paris: L'Harmattan. Bergadaà, M. (2013), "Responsable". Obtido em 12 de janeiro de 2014 em http:// responsable.unige.ch/

Gallant, T. B. (2008), Academic integrity in the twenty-first century: a teaching and learning imperative. Association for the Study of Higher Education. Higher Education Report, 33(5), San Francisco: Jossey-Bass.

Hallak, J. e Poisson, M. (2002), Ethics and corruption in education: an overview. Results from the Expert Workshop held at IIEP, Paris. Policy Fórum, n ${ }^{\circ}$ 15. International 
Institute for Educational Planning/UNESCO. Paris: UNESCO. Obtido em 7 de março de 2009 em http://www.unesco.org/iiep/PDF/Forum15.pdf

Heyneman, S. P. (2013), "The University as Public Goods: Ethical Underpinnings". Knowledge Studies in Higher Education, 1, 205-213.

Macdonald, R. e Carroll, J. (2006), Plagiarism - a complex issue requiring a holistic institutional approach. Assessment and Evaluation in Higher Education, 31(2), 233-245.

Macfarlane B.; Zhang, J. e Pun, Annie (2014), "Academic integrity: a review of the literature". Studies in Higher Education, 39(2), 339-358.

Manly, T. S.; Leonard, L. N. K. e Riemenschneider, C. K. (2014), "Academic Integrity in the Information Age: Virtues of Respect and Responsibility". Journal of Business Ethics, 127(3), 579-590.

McCabe, D.; Treviño, L. K. e Butterfield, Kenneth D. (2002), "Honor Codes and Other Contextual Influences on Academic Integrity: A Replication and Extension to Modified Honor Code Settings". Research in Higher Education, 43(3), 357-378. Pedersen, H. S. (2015), "Are PhDs winners or losers? Wage premiums for doctoral degrees in private sector employment". Higher Education, Publicado online a 30 de maio, 1-19. 
(Página deixada propositadamente em branco.) 


\title{
ANEXO
}

Transcrição, abreviada e editada, mas mantendo o tom coloquial, dos debates do Colóquio

\section{“A ÉTICA DOS ALUNOS E A TOLERÂNCIA}

\section{DE PROFESSORES E INSTITUIÇÕES PERANTE A FRAUDE ACADÉMICA NO ENSINO SUPERIOR”}

\author{
Coimbra, Faculdade de Economia, 8 e 9 de maio de 2014
}


(Página deixada propositadamente em branco.) 
Ana Seixas: Muito obrigada. Passaremos, então, ao debate. Poderão colocar as questões em português porque haverá sempre tradução em francês.

Paulo Peixoto: A minha questão é dirigida a Michelle Bergadaà. A Michelle focou, concretamente, a questão da intencionalidade como um nível fundamental para avaliarmos o plágio. No projeto que desenvolvemos, trabalhámos com estudantes de graduação e fica... entre várias vontades... fica-nos a vontade de trabalhar, quer com estudantes de pós-graduação, mas também com alunos que estão abaixo do ensino superior. Porque, pelo menos para mim, há uma quantidade de comportamentos - que deveria ter uma resposta institucional diferenciada, que não olhe para todos os tipos de plagiadores e de plágios do mesmo modo - que são muito diferenciados se questionados a partir da questão da intencionalidade. Porque há também uma cultura de plágio que nós identificamos - e não vou agora falar dos resultados ou das observações a que chegámos -, mas há uma cultura de plágio que resulta, não da intencionalidade, mas da própria ignorância em relação ao que poderia ser uma boa conduta ética e que está muito presente na cultura que os alunos trazem quando chegam ao ensino superior. E a minha questão era concretamente essa, se nós adotarmos esta perspetiva da intencionalidade como é que lidamos com essa parte menos intencional? Não sendo propriamente um manipulador, onde encaixamos esse tipo de plagiador que tem de ser... sensibilizado para as questões da ética e do plágio? Outra questão que gostaria de levantar, mais geral, e que vocês poderiam pegar nela, como entenderem... nós, no estudo que fizemos, olhamos muito... e a Professora Teresa Estrela focou esse 
aspeto... e é uma das coisas que a mim pessoalmente me interessa... Nós decidimos conscientemente, quando fizemos o estudo, que não íamos abordar nem a fraude cometida pelas instituições de ensino superior, nem a fraude docente... nós íamos olhar só, exclusivamente, para a fraude cometida pelos estudantes. Mas, olhando para os códigos das instituições... a mim o que mais me espanta é que em Portugal, nos diversos códigos... códigos de ética... códigos disciplinares... qualquer que seja a sua natureza, a fraude cometida pelos estudantes é sempre algo de marginal, mas a fraude institucional e a fraude dos docentes nem sequer existe. Ou seja, a questão da ética vai existindo, ainda que marginal, mas as outras fraudes... cometidas por docentes e instituições não existem. A questão é: nós podemos realmente abordar a fraude dos estudantes sem abordar as outras duas em conjunto?

Michelle Bergadaà: Muito obrigada por esta questão. Não sou a única com capacidade de responder, mas vou inicialmente inverter os 4 pontos. Todos os estudantes consideram injusto se nos referimos à sua fraude, ao seu plágio, por exemplo, e que não digamos uma palavra sobre os seus professores. Não são, de todo, ingénuos. Vão à Internet, pegam nos PowerPoint dos seus professores e apercebem-se que são os PowerPoint de um outro professor ou traduzidos. Dizem-no. Escrevem-me e dizem-me "o meu professor é um plagiador". Consideram isto totalmente inadmissível. Em segundo lugar é evidente que são, se posso dizê-lo, os mesmos perfis. São as mesmas práticas. Portanto, abordar a questão dos estudantes e não a dos docentes é estúpido. São seres humanos que têm a mesma tipologia e as mesmas práticas. Em terceiro lugar, é verdade que na Universidade de Genebra temos agora.... abordamos agora as duas questões, mas não posso dizer "OK, temos um só regulamento". Temos, na verdade, dois regulamentos diferentes e duas práticas diferentes. Mas, pelo menos está no mesmo link onde está indicado "plágio". Sobre a intencionalidade dos estudantes. A intencionalidade 
dos estudantes... não seria professora se não gostasse de estudantes, gosto muito deles... e, por exemplo, ... no estudo que foi feito junto dos estudantes, é intencional, mas por razões admiráveis. Um disse: "plagiar é uma questão de circunstância. Plagiamos muito mais na Primavera e no Verão, quando está bom tempo, que durante o Inverno". É magnífico como... um outro diz "Eu agora montei um site onde tenho todos os trabalhos e onde posso explicar aos outros como fazer... e tenho bastante sucesso junto das raparigas, desde que sou um badboy", OK, OK. E então a intencionalidade... é verdade que os estudantes quando chegam à universidade, não aprenderam... tive, e vocês tiveram, forçosamente, todos os que têm filhos que um dia foram adolescentes, o meu filho teve que fazer um trabalho e... tinha-o copiado de documentos que eu própria tinha recolhido, sem citar. Era para o seu trabalho de BAC, fim de liceu. Mas eu disse: isto é plágio. Não podes fazer isto! — "Não, não. Não tenho tempo". E eu digo: "não podes. Não é possível". E eu tive... o meu filho é agora casado, adulto... tem uma ética irrepreensível, mas quando tinha 19 anos... era impossível para mim, mãe, explicar-lhe que o que estava a fazer era não ético. Que era necessário citar as fontes etc. Isto quer dizer que o filho de um trabalhador, cuja mãe não é professora, não tem tantas hipóteses de se aperceber de tal. E, agora, a última questão... o mais admirável... é que os nossos estudantes são muito maleáveis. Ainda são jovens, acreditam ainda no que lhes dizemos. Assim, se os fizermos participar... E recomendo a todos a apresentação amanhã de Christelle Cotton, sobre, precisamente, a abordagem participativa. Se os fizermos participar, eles encontram coisas fantásticas. No Québec, perguntaram aos estudantes "qual é a mensagem que é melhor para vocês?" Passaram diversas mensagens. Estudo experimental de Laval... não... E nas mensagens, havia: o medo, o "plágio-mau"... havia outra que era simplesmente "uau, é teu... e citei-te... e todos os estudantes reconheceram... Porquê? Porque funcionam na lógica do like...I like, I like.... OK, cito este texto, será que 
te posso citar? É necessário entrar nas mentalidades deles, é preciso trabalhar com eles... perguntar-lhes o que funciona melhor... não é de todo o que nós acreditamos... não é o medo... não é o facto de estar mal... não é o facto de que faria mal ao coração dos pais ou dos avós que pagaram os estudos... é o I like... uau é teu, logo, citei-te. Assim, é preciso perguntar aos estudantes... é necessário perguntar a esta geração o que é que lhes serve? E aqui penso que, efetivamente, a mensagem entre os professores-investigadores e os estudantes não é a mesma. Aqui afastamo-nos. Mesmo que tenham as mesmas práticas, a maneira de resolver o problema é muito diferente.

Público: Na universidade do Minho, o código da universidade também tem uma parte sobre professores.

Ana Seixas: Mais alguma questão?

Jude Carroll: Não se trata de uma questão. Estava só a dizer "esperem... talvez as pessoas possam pensar". Mas eu tenho uma questão. Se o problema é tão sério, o que podemos fazer para que a resposta das universidades seja tão séria quanto o problema? Como é que podemos ajudar as universidades, que têm tantas coisas em que pensar, a tratar este problema com a mesma seriedade com que outros assuntos são tratados pela universidade?

Jacques Hallak: Penso que esta é uma questão que se dirige à comunidade, à instituição universitária. Se me permite, levo 3 minutos a expor o meu sentimento. Primeiro, como sabe, vivemos fora de tudo o que declarámos até ao momento. Algo muito recente e devastador para certos casos, positivo para outros, é o que chamamos as "mouques"; ${ }^{26}$ é esta intrusão generalizada do ensino à distância apoiado sobre meios múltiplos, informáticos e outros... de acesso gratuito, com processos multiformes que nasceram em certos lugares nos EUA, que estão a espalhar-se um pouco por todo o planeta. A semana passada soube que na China há diversas universidades que se reuniram para

\footnotetext{
${ }^{26}$ MOOC - Massive Open Online Course
} 
fazer o seu "Mouque" também. Em França, ao nível do Ministério do Ensino Superior, lançámo-nos na questão. Então, há um primeiro problema: será que esta mudança, que em si mesma oferece oportunidades imensas, altera as situações de plágio, de fraude académica, de não respeito de toda uma série de normas... e códigos? Será que medimos, apreciámos, vimos, relativamente a isto, o que pode fazer a universidade, enquanto instituição formal, enquanto instituição? Penso que há algumas instâncias, nomeadamente ao nível da UNESCO... e mesmo fora da UNESCO, associações mundiais e regionais de Universidades, incluindo a "Association des Universités Novatrices" que está sob a égide de um grupo que se encontra em Barcelona, que se estão a aperceber deste problema... e é um problema que... que vai ser um problema muito preocupante para a universidade. Porque, verdadeiramente, aqui saímos dos muros, saímos praticamente de todas as convenções. Assim, há aqui um enorme desafio... enorme. Não falo da fraude, falo da organização em si. Da função mesma da Universidade. Segunda observação, e aqui falo sobretudo dos países em desenvolvimento e dos grandes países. As novas funções sociais da universidade não são mais, unicamente, a capacitação e a aquisição de saber... mas as de preencher funções políticas e sociais nos países em desenvolvimento. Chama-se desenvolvimento regional etc. Pode ser proteção da natureza, pode ser todo o tipo de funções... e face a estas funções... há muito trabalho a fazer, há muito trabalho começado, etc. Quando abordo a história da fraude académica, e não do plágio, não me permito comentar este problema que me parece a mim duvidável. Creio que devemos ir, forçosamente, a um sistema de rotulagem, pedindo perdão pela apropriação da palavra usada pela Michelle. Há cerca de 10 anos, quando começamos a fazer o primeiro trabalho na UNESCO, no Instituto Internacional de Planificação da Educação, tinhamos um conselho de docentes e professores de cerca de 20 universidades que nos pediam para trabalhar numa rotulagem. Mas tivemos, naturalmente, o cuidado de não nos lançarmos neste 
género de coisas, porque ao nível internacional coloca problemas questionáveis e aqui a corrupção política pode destruir todo o efeito e todos os efeitos em seguida. E creio que há pistas que a Michelle vai partilhar em seguida.

Michelle Bergadaà: Sim, obrigada. É uma bela interrogação. O que é claro é que quando... disse que estamos num mundo violento... no sistema universitário... num mundo informal... por ser informal é talvez ainda mais violento que o mundo formal. Fazemo-nos muito mal mutuamente. Algo que o Jacques disse agora é verdadeiramente fundamental e é preciso reter. Ao nível socioeconómico, se tomarmos a análise ao nível do sistema, já é demasiado tarde. Por exemplo, há em França uma universidade que se chama Paris VIII onde há um investigador que não pára, há anos, de provar que há plágios, que há teses de complacência; isto é, teses não merecidas. Mostra no seu blogue os exemplos de um Professor que fez plágio e a resposta desta Universidade na semana passada é a de ter estabelecido um Comité de Ética onde está presente o plagiador, o Professor Plagiador... Por que é que fizeram isto? Fazem dentro de 15 dias uma conferência sobre a ética onde ele vai igualmente estar. Não é para fazer pouco do sistema universitário. É porque custa incomparavelmente mais caro excluir um dos nossos pares do sistema... do que o deixar integrar-se e depois de o meter em qualquer lugar. Portanto, é tarde demais. O sistema basculou. É preciso compreender, desde logo, este facto. O que é que podemos fazer para ajudar? Neste momento é preciso mudar. Quer dizer ... é o que eu tentei dizer... com os estudantes, trabalhar com os estudantes... mas igualmente voltar à avaliação pelos nossos pares. Isto é, se os Presidentes de Universidade ou o sistema universitário não pode tratar o caso de todos os Professores que já cometeram fraude... entre nós... quantos são não sei e não me interessa... não me impede de dormir... mas o único meio é o de fazer avaliações entre pares. Isto é, talvez o sistema alemão, os alemães não hesitam colocar as teses na $w e b . .$. e qualquer um pode 
ir ver e detetar "ah sim, olha aqui é plágio, aqui há fraude". Quer dizer, voltar a um sistema que vai ser colaborativo. Servir-se da web para voltar ao colaborativo. É, penso, o futuro da web... e o nosso futuro comum para salvar a universidade. A partir do momento em que cada um de nós sabe que os seus escritos vão estar na web e vão poder ser analisados e criticados, isto vai fazer abrandar o sistema... a produção de fraude e de plágio. Querer lutar, hoje, pelo institucional, por alto, não é possível. Acabou. Estou totalmente de acordo com o que o Jacques disse.

Jacques Hallak: Digo aliás que no IPE, no instituto da UNESCO, todas as teses, antes de serem examinadas, passam pelos testes de plágio. Só quando passam os 3 testes podem ser defendidas. Portanto, vai ao encontro do que diz a Michelle. Na realidade... o que deve ser feito não é ao nível macrossocial e geopolítico. É ao nível de cada universidade, de cada instituição... de assumir que é... indo em direção a qualquer coisa verdadeiramente incontestável que se torna incontestada. E é sempre assim que para ser ser respeitado é preciso ser respeitável. Mas... é bom que saibamos, contudo, que nos encontramos frente a um problema de massificação e concorrência violenta, onde gira muito dinheiro, onde estão muitas coisas em causa e é o contexto no qual muitas universidades, no continente Europeu, estão a sofrer. Porque mesmo a ajuda à investigação que recebem está a tornar-se cada vez mais difícil de obter junto das autoridades públicas. Há uma privatização do financiamento. O privado não é mau, mas uma privatização condicional que vai em direção a qualquer coisa que mete em perigo a integridade, aí sim, há um problema. Assim, julgo que é preciso atuar, de forma pragmática, ao nível de uma faculdade de economia, de direito etc., ao nível de um pequeno instituto, como aquele ao qual pertenço e que aconselho, de modo a entrar neste sistema. Digo-vos que, atualmente, há sensivelmente 12 sistemas de controlo de plágio diferentes, 12! E gratuitos.....acessíveis. 
Hermano Thiry-Cherques: Eu gostaria de relatar a experiência que nós hoje estamos utilizando. É parecida com essa que o Jacques falou. Mas há uma coisa a assinalar. Uma coisa são as disciplinas ou faculdades das ciências exactas. A outra as das ciências humanas e sociais. Ou seja, é difícil fraudar um cálculo de resistência de uma ponte, não é? Um engenheiro vai trabalhar com isso. Também é difícil fraudar o cálculo de risco de um projeto. Isto do ponto de vista dos exames. Na parte da técnica, o que nós temos feito, com isto, é um sistema copiado dos alemães e que tem dado resultado, que são as provas, ou os testes de múltipla escolha... não é... eu, por exemplo, trabalho com 60 aulas e 58 testes. Há testes, toda a aula, sobre o tema anterior, 5 minutos. Mas não há como enganar ou fraudar esse tipo de coisa. E nas matérias de reflexão, se pede que reflitam. Ou seja, não é uma questão de citações ou de mostrar conhecimento, é uma capacidade do aprendizado aprender. Dou o exemplo de um teste recente, que a questão era uma só: o fiscal de rendas é um ser humano? Justifique a sua resposta. A pessoa tem que refletir. Não tem como se socorrer em outros autores, outros textos... ela ali tem que refletir. Em relação às dissertações de mestrado, aos trabalhos de mestrado, temos adotado a solução americana de que também falou o Professor Jacques Hallak, que é, simplesmente, não há teses, não há trabalhos de mestrado. Há uma prova. Uma prova de suficiência. É muito difícil de ser fraudado assim... e nas teses doutorais, a publicação da defesa online, as defesas de teses são sempre feitas via skype...ou seja, a defesa é pública e online, tanto para os examinadores como para quem quiser ouvir... e a publicação imediata na web. Ou seja, todo o mundo tem algum inimigo que vai querer provar que ele plagiou a sua tese. Como esse senhor da Paris VIII, que se dedica a isto. Em toda a rua, existe uma senhora que fica vigiando quem entra ou sai das outras casas. Isso é do ser humano e a publicidade é que vai fazer isso. Nós tivemos casos de dirigentes europeus que tiveram... até perderam o seu posto de mandato político, por haver 
plagiado na sua tese. Simplesmente porque ela é colocada de forma pública. Qualquer um pode ir lá e olhar. Claro, um político vai ter sempre quem... o inimigo, o adversário, o inimigo político, que vai ver que a sua tese não estava bem... ou que estava plagiada. Isso praticamente eliminou essa questão da cópia na tese ou das citações que fazem... que uma tese seja um bricolage. Uma tese é um conjunto de citações, de pensamentos alheios, não é? Porque a publicidade mata essa possibilidade. Isso faz com que a universidade tenha que se abrir para o mundo exterior.

Teresa Estrela: Isto pode ser um bocadinho de ingenuidade da minha parte, mas termino como comecei. A montante está a formação ética dos alunos e, portanto, penso que se as universidades querem tomar a sério o problema, devem começar por sensibilizar os professores. Para eles todos. Existir uma ação pedagógica nesse sentido... e, portanto, através... da transversabilidade dessas questões no currículo, através de um esforço permanente, podem sensibilizar os alunos. Porque quando as pessoas entram num certo hábito, às vezes não basta essa vigilância. Eu lembro-me de um caso que para mim é exemplar. Antigo orientando meu, que foi vítima de não sei quantos plágios.... e escreveu ao colega que o plagiou. A resposta do colega: que ele tinha que fazer carreira, simplesmente. Tinha que fazer carreira. E é interessante é que essa mesma pessoa apresenta a sua tese, plagiada, com o instituto de a publicar. Com muito pouca sorte veio ter comigo, que conhecia muito bem a tese e, portanto... mas foi uma lição de moral.

Michelle Bergadaà: Permito-me dizer, perdão, temos todos exemplos pessoais... mas o que é preciso ver é que, se mais de $50 \%$ dos nossos estudantes, fazem plágio, fraude, temos a mesma percentagem entre os nossos colegas. Então, por que é que um professor plagiador teria vontade de dar lições aos seus estudantes? Não o fará. Assim, é verdade que não é possível. Pensámos nisso. Mas não é mais possível, porque com a pressão para publicar, mais e mais 
investigadores e professores estão negligentes e, se são negligentes, não têm vontade de se ver ao espelho, lembrando as regras de plágio e ética aos estudantes. Porque se magoam psicologicamente a eles próprios. Assim, fazem como se não existisse. É importante admitir a percentagem. A percentagem é extremamente elevada. Perdão, $50 \%$... nos nossos países. Não fui ver na China, não fui ver à URSS, nem ao Congo-Brazzaville.

Jacques Hallak: É preciso dizer, sobre este tema... que nos nossos países, bom, estamos na Europa... assistimos há 20 anos... mas sobretudo há 10 anos a uma despossessão das responsabilidades universitárias mais elevadas dos pedagogos, dos académicos, em proveito dos responsáveis administrativos, da Governância etc. Segundo um estudo da OCDE que tem agora uns anos.... um estudo comparativo sobre certas universidades europeias, as propostas de trabalho para a função de responsáveis universitários, não se lhes pede que sejam doutores em tal ou tal especialidade... mas sim que sejam especialista de... É uma questão de negócio. Por outras palavras, a função gestionária das universidades separa-se cada vez mais, mesmo no recrutamento e acesso ao trabalho, do mundo académico. E assim, encontramo-nos numa realidade que, para um economista, é muito desastrosa. As medidas de incitação implícitas impedem os académicos de seguir de perto os seus estudantes para os encorajar a não serem fraudulentos e a não cometerem plágio. A única luta, simples, contra o plágio, é o acompanhamento. É dar tempo ao estudante. É seguir o seu trabalho. É verificar que ele avança. Assim, num mundo universitário que é cada vez mais gerido por não académicos, por uma separação das funções gestionárias com a parte pedagógica e académica, os responsáveis pela governação da universidade, por razões de gestão estratégica e outras, são levados a criar medidas de incentivo que estão totalmente em desfavor da luta contra o plágio e pela excelência. E isto passa-se na Europa. Então, temos aqui um desafio adicional a gerir. 
Paulo Peixoto: Gostaria só de fazer uma pergunta. Esta reflexão final, que fizeram agora, é interessante, do meu ponto de vista. Sou adepto de se acabar com os exames e partilho convosco um pouco esta perceção de que a solução mais adequada é a construção da relação pedagógica com os estudantes. Ou seja, nós sabemos que a falta de tempo dos professores, a fraude institucional, é muitas vezes a instituição que promete uma orientação que depois não dá ao aluno, não é? Sou adepto de se acabar com os exames mas não porque considere que acabando com os exames se vá acabar com a fraude. É que quanto mais se acaba com os exames, mais os professores se dão conta que o tipo de fraude que os estudantes cometem é também aquele tipo de fraude que os professores cometem. Colocar o nome num trabalho em que nós não participámos ou num texto em que nós não escrevemos. Apresentar o mesmo trabalho, com o mesmo texto, um pouco retocado, a várias disciplinas... e... acho que quanto mais... a questão que Jacques Hallak colocou, que para mim é relevante, é como é que nós combatemos aquele que é o poder mais desejado pelo professor. O professor gosta de avaliar. O professor vê-se como um avaliador. E tem muita dificuldade em se avaliar a si próprio com os mesmos padrões com que avalia os estudantes. E quanto mais os professores sujeitam os estudantes ao mesmo tipo de avaliações a que eles são sujeitos, mais me parece que eles são obrigados a reconhecer, e mais as instituições são obrigadas a reconhecer, que a fraude não é um problema dos estudantes. É um problema institucional. A razão pela qual nós também... e amanhã vamos ver isso... com a intervenção da Christelle Cotton, que traz o depoimento de uma intervenção institucional que nós conhecemos e que admiramos, ... a razão pela qual defendemos uma perspetiva de uma política integrada que não olha apenas para a fraude nessa perspetiva de que o problema está nos estudantes. Eu partilho muito esse sentimento que o fundamental é a relação pedagógica. Agora, as condições objectivas atuais das instituições para garantir essa relação 
pedagógica é que são muito difíceis de garantir, não é? cada um de nós sente as pressões de diverso modo... e isso é praticamente impossível, não é? Como é que hoje nós trabalhamos com as instituições para ultrapassar esse problema? Esse parece-me o grande desafio.

Jacques Hallak: Queria fazer um pequeno comentário sobre o que o Professor Hermano disse há pouco. Estou preocupado. Ouvi-o com muita atenção, quando falou da relativização... da transformação dos valores éticos, com a evolução tecnológica, científica etc. atual. E não sei se teremos oportunidade de discutir esta questão hoje... ou se é melhor deixar para amanhã. É que coloca-me, a mim, um grande problema... esta problemática da relativização dos valores éticos. Não porque não compreenda a fonte desta informação, mas porque não vejo onde se centra o ponteiro. Onde colocar o ponteiro da relativização? Porque posso especular... posso prever que com este método, arriscamos dirigir-nos para um caminho que pode ser desastroso para todos nós. Sei que não é o que pensa o Hermano.

Michelle Bergadaà: Eu sou igualmente contra a relativização... porque dentro de tudo o que é a fraude e a corrupção, relativizar... é verdade que podemos dizer que a criança indiana precisa de fazer sobreviver a sua família aos 11 anos a fabricar sapatilhas Nike... por exemplo... mas teoricamente deve estar implícito e não tido como um dado adquirido. Há outro termo que ouvi e me chamou a atenção... foi a Teresa que o disse, é a honra. Então é absolutamente incrível mas... devo ser muito velha... porque, para mim, a honra quer dizer qualquer coisa... para mim... a minha honra faz com que eu nunca tenha... quanto mais não seja por orgulho... roubado uma linha de outra pessoa. A minha honra é de conseguir deitar-me à noite e dizer que fui honesta durante o dia. Que talvez tenha sido severa com os estudantes mas... para o seu bem. A honra de uma profissão significa qualquer coisa. Agora, não é isso... falta um índice de citações... falta saber quanto são avaliados no índice de citações americano, digamos que é muito anglo-saxónico... com jogos verdadeiramente 
extraordinários, publiquei mais de 100 artigos. Comecei a colocá-los, não em open-Access mas em sites onde... se me citam ou me interrogam... aumentam o meu índice de notoriedade. E assim, certos colegas fazem-no... e em contrapartida, é suposto interessar-me nos seus artigos, descarregá-los e citá-los. Não para aumentar o meu índice... é totalmente artificial... mas porque assim eles vão fazer a mesma coisa por mim. Estamos num mundo onde já não há honra. É algo... não é que já não exista, ponto. Creio que faz 20 anos que deixei de ouvir o termo "honra". Então estou muito contente de ter vindo a esta conferência. É um prazer. Muito obrigada por terem utilizado este termo.

Coimbra, 8 de maio de 2014

Paulo Gama: Está aberto o debate, as vossas questões são importantes.

Jacques Hallak: Olá, obrigado pelas três apresentações. A sério que achei apaixonantes as três. Quero colocar 3 questões, mas vou colocá-las já. As duas questões prolongam as apresentações... isto é, não as interrogam, prolongam-nas. A primeira questão sobre o tema de Lovaina, de uma experiência apaixonante. A questão é a seguinte: houve já uma avaliação desta experiência em curso... e, por exemplo, será que temos uma indicação sobre a evolução de... um grande número de sanções... de... de casos um pouco duvidosos e não, para as 3 categorias... será que temos indicações de que se evoluiu, e em que direção? Se regredimos no caso mais grave para o caso médio, ou do caso médio para o caso menos grave? Fiquei bastante apaixonado pela primeira escala formativa, porque ela recorta ao nível macrossocial, macroeconómico, o conceito de luta contra a 
não ética... ou a fraude... de maneira participativa. E a abordagem participativa, parece-me a mim, cheia de potencial, e penso que o que se passa em Lovaina... e gostaria de saber se há qualquer coisa e se há uma avaliação, uma monitorização... do que se passou desde o início e se há números. A segunda questão prolonga igualmente a intervenção brilhante, mas verdadeiramente brilhante, deu-me prazer ouvir e agradeço-lhe Professor. Colocou o dedo sobre... que do ponto de vista político... é muito importante e sai mesmo do domínio da educação, que é finalmente aquele da concorrência na investigação científica. Sabia que em Singapura, votaram cartas éticas na investigação que infelizmente não resultaram em nada e isto lembra-me a história da descoberta... da SIDA e da luta contra a SIDA e da luta entre um investigador francês, que foi o primeiro a descobrir, e que viu ser roubada a sua investigação por laboratórios americanos, etc. Então chego à minha questão: a minha questão centra-se no cenário número $2 \ldots$ os 3 cenários, entre Fernandes... e o outro... como é que chama?

Luís Adriano Oliveira: É ficcional, ficção.

Jacques Hallak: A questão é a seguinte... é claro que no cenário 2 há um bloqueio assim que há avaliação pelos pares, porque os pares esperam-se próximos dos temas. E então sempre em concorrência com a equipa em causa. E a problemática da avaliação pelos pares, da validação pelos pares... é de uma natureza que não sei resolver... não sei como podemos resolver. E por que é que não a sabemos resolver? Porque, na realidade, podemos ter duas posturas. Uma postura, digamos à Max Weber: há uma ética de responsabilidade etc. que é partilhada... é um pouco ingénuo... desculpem que o diga, enquanto investigador e estudante e observador da cena académica, há anos. Portanto, esta postura um pouco romântica ou um pouco ideal, não é a realidade. Está longe da realidade. E estamos num problema difícil porque, quem pode validar senão as pessoas que estão no interior? Ora as pessoas do interior estão em competição com as pessoas que 
devem validar. Então como é que podemos, mais ou menos, abordar esta problemática e aqui vi que colocou a questão, tem vontade de ensinar a questão, colocando este problema ético aos estudantes e mesmo aos docentes e, creio que, para nós, investigadores que somos, é uma questão fundamental, sobretudo, no domínio das ciências exactas. Porquê? Porque aqui há imediatamente interferência da indústria... e da grande indústria. E diz respeito a tudo, incluindo a investigação ao nível dos softwares etc... e são milhões... que estão por trás. E então, há indústrias.... que estão à procura do mínimo progresso, de uma mini pequena start-up que faz investigação... e polui esta investigação. Estamos longe do plágio, estamos mais longe. Não quero ir às distinções que fizemos no início da noite.

Christelle Cotton: Ora, temos números, sim. Ora, antes de o projecto existir, tínhamos, em 2004-2005, um caso de plágio que tinha sido assinalado. No ano passado, no total, tínhamos cerca de 20 casos que foram assinalados, com níveis de sanção diferentes. Mas este é um dos agrupamentos sobre o qual, precisamente, o grupo de trabalho, se debruça.... Disse-o antes... agora este grupo tem um papel de vigilância e um papel de iniciativa para a manutenção da ação antiplágio... e na parte vigilância da missão há evidentemente uma vontade de poder monitorizar as coisas, mas leva bastante tempo... porque, primeiro colocámos em curso um procedimento para recuperar a informação diretamente através dos docentes e dos júris. Mas ainda não se tornou um hábito. E não queremos, as autoridades da universidade não querem, impor este procedimento de comunicação aos seus docentes e de acrescentar uma limitação complementar. Mas as coisas chegam suavemente. Porque sistematicamente há uma reação em relação ao docente e em relação ao estudante. E estamos bastante conscientes do facto de que esta monitorização é indispensável para o desenvolvimento. Depois, acho que a avaliação sobre 2 níveis pode ser quantitativa mas deve igualmente ir mais longe e quase descer ao nível do dossier de cada estudante, para verdadeiramente ter uma 
grelha de análise muito precisa. Casos presentes, como podemos agir face a estes diferentes casos? Então este campo está muito muito longe de estar encerrado.

Luís Adriano Oliveira: Obrigado, Professor Jacques Hallak. Se me permite, vou responder, usando o ponto de vista de um docente que se dirige aos seus estudantes, porque é o tema da comunicação. Então se... analiso esta questão desde o início... posso perguntar a um aluno, quem pode ser investigador? Quem pode fazer investigação? Quem tem qualidades? Evoluímos muito. A boa nova é que evoluímos muito desde... Leonardo da Vinci, Einstein, Professor Tournesol, genial e louco, um pouco, há esta caricatura... dos investigadores e... temos, hoje... os últimos séculos assistiram a uma profunda democratização do conceito de investigador. Agora, os estudantes da universidade podem ser investigadores, serem seres completamente normais como os estudantes e fazerem a festa à noite... garantindo que sejam apesar de tudo um pouco prudentes. Bom, mas a má notícia é que a demografia da comunidade científica "explodiu" e o financiamento da investigação não conheceu uma evolução paralela. $\mathrm{E}$, assim, toda a gente puxa pelo dinheiro para fazer investigação e competição, concorrência. É, portanto, uma realidade. Não podemos fazer nada, é assim. Quando se trata, então, de abordar o problema da concorrência entre pares, estou totalmente de acordo. Só as pessoas que estão no mesmo domínio é que têm as competências para desenvolver o trabalho que eu faço. Desde logo, há dois, a meu ver... há dois fatores de esperança. Vou talvez parecer-vos ingénuo mas penso que o espírito da investigação e da universidade... sei que nem todos estarão forçosamente de acordo... - foi mesmo dito, ontem, que a universidade é talvez um lugar de malformação-, mas vou talvez parecer ingénuo, mas a meu ver a universidade promove os bons valores e os investigadores fazem mesmo parte de uma classe que pode dar-se ao luxo de orientar a sua atividade em função de certos valores que estão de acordo com aquilo que entendemos pela 
ética da investigação. Assim, a meu ver... devemos esperar que as pessoas que têm o peso de avaliar um trabalho, em grande maioria, são pessoas que o vão fazer corretamente. Mas, há evidentemente exceções. Assim, uma medida possível para combater esta exceção é de colocar em questão o anonimato dos revisores. Há-os... bem... isto é totalmente discutível. Abordei um pouco a questão... sei que o anonimato é necessário por vezes... mas o anonimato protege este tipo de fraude sobre a qual falei há pouco. O cenário 2 e o cenário 1. Assim, há neste momento um certo número de revistas que exige que os examinadores... os reviewers, os pares... sejam identificados. Se não querem ser identificados, não serão convidados.

Michelle Bergadaà: Continuo então sobre este tema. Vou completar. Fizemos um estudo com os colegas sobre a minha base de dados... não apresentei ontem, não tinha tempo. Vai o plágio aumentar ou não nos anos que se seguem? De maneira muito clara nas ciências sociais, o plágio tinha aumentado em $70 \%$ e ficaria igual nos $20 \%$ e diminuiria em $10 \%$ e nas disciplinas científicas seria sensivelmente a mesma coisa. Iria aumentar unicamente $32 \%$. Então as questões em seguida seriam... porquê? $\mathrm{E}$ as respostas eram muito claramente... e isto é verdade, foi observado em todos os casos que estudo há 10 anos... são as revistas científicas de bom nível, sublinho "bom nível", onde há um redator chefe, que são unicamente "chefes de estação ferroviária”, que veem passar o pequeno comboio da revisão. Que são capazes de se envolver, que são capazes de escolher bons reviewers. Em todos os comités editoriais... faço parte de bastantes comités editoriais... se não fizermos bem o nosso trabalho, somos ejetados. Assim, guardo e conservo uma grande confiança no processo de revisão de revistas científicas que são capazes de colocar rapidamente processos de regulação, de "ejetar" maus reviewers, de receber queixas: para a semana vou falar, com redatores chefe, de comissões de ética sobre revistas científicas que puseram em prática processos. As revistas científicas, verdadeiramente científicas, não hesitam agora a dar-me 
o nome dos batoteiros. Isto é, de dizer "retiramos o artigo" e aqui está a infração cometida por tal e tal pessoa. Desculpabilizam-se junto dos leitores, o que é muito bem feito, e ainda por cima retiram o artigo. Neste momento tenho três casos a tratar, no qual um é um estudante que não foi incluído pelos chefes como autor do artigo... vai ter o direito, no mesmo momento em que o artigo vai ser publicado, de apresentar o seu quadro de tese e de dizer "mas é o meu quadro" que é reutilizado. Assim, temos no mundo científico uma regulação. Não acredito de todo, no entanto, e disse-o ontem... e permito-me reutilizar uma frase da Jude... o mundo universitário - onde são os não científicos, onde são os não pares que estão à cabeça dos estabelecimentos, ou são administradores ou "pares" que esqueceram o que é a investigação... - é um mundo complexo e é porque é complexo que não acredito que possamos encontrar soluções totais. Penso que cada laboratório, enfim, talvez me digam o contrário, mas é aqui que reentro na vossa abordagem que é individualista... penso que diz respeito a cada laboratório, a cada orientador de tese, a cada faculdade a decisão de quais são as melhores práticas numa ética prática. E ainda ao nível do sistema, penso que podemos fazer ainda bastante com as revistas científicas, porque, precisamente, estamos no controlo... enquanto que acho que o combate está perdido ao nível das instituições. Mas... lamento por Lovaina, mas penso que está perdido, porque nem toda a gente vai seguir. Tinha uma coisa a acrescentar sobre a última intervenção. Tentámos na Suíça fazer com que os estudantes de doutoramento se inscrevessem na disciplina "como fazer uma apresentação oral", "como melhor falar inglês"... como... tudo o que é imediatamente utilizado na prática. Mas quando lhes pedimos para seguir aulas de ética, temos 5 inscritos. Nas outras disciplinas (as do "como...") eles são 30. Assim, na conferência universitária das escolas suíças, abordámos todos os reitores dizendo: "tentem pedir aos professores que incentivem os estudantes a inscrever-se em aulas de ética”. Bom, o resultado é nulo. 
Luís Adriano Oliveira: É preciso colocar a ética no seu tema, é... é útil.

Michelle Bergadaà: Os professores não têm vontade e vão mesmo dizer "para que é que os meus estudantes vão perder o seu tempo a ir a esta aula"? Assim, falamos a mesma língua mas não vejo.... a minha questão aos 3 é: veem como incentivar os estudantes para a ética da responsabilidade? Sim, qual é a alavanca? Dirijo-me aos 3. Em Lovaina parece crerem que é o estudante. Mas, Jude, qual é a alavanca para...

Jude Carroll: Penso, penso que sei o que estás a perguntar.

Michelle Bergadaà: Quem é responsável pela introdução da ética nas nossas aulas? Para os nossos estudantes ao nível dos programas de doutoramento. Não sei porquê para os estudantes em doutoramento, não são as competências imediatas. Assim, o que é a ética? Não é importante para eles e para os seus professores. Não estão certos?

Jude Carroll: Penso que falar línguas diferentes é muito interessante e penso que o que pergunta é particularmente sobre estudantes de doutoramento e quem é responsável e escolheu um contexto particularmente difícil. Estudantes de doutoramento são realmente difíceis. Mas a razão pela qual são difíceis é porque estamos a mover-nos da área de estudantes para a área de profissionais, de colegas... de pessoas que são reconhecidas como académicos. Em todas as discussões sobre plágio, sobre copiar, sobre ética, há reais diferenças na discussão da responsabilidade dos estudantes e a responsabilidade dos colegas académicos e investigadores... e os estudantes de doutoramento são bastante difíceis porque estão numa linha fronteiriça. Estão entre os 2. Assim, neste domínio, tendo em conta que os estudantes de doutoramento são estudantes, as pessoas responsáveis são os supervisores. Recebo teses de doutoramento de universidades que não têm coragem e que dizem "isto é um doutoramento plagiado?" $\mathrm{E}$ eu, a trabalhar num tema que não conheço minimamente, demoro 20 minutos a dizer sim... e não é difícil. Quando este documento 
final é produzido e alguém me pergunta "isto é plágio?" ... e eu posso responder sim em 20 minutos, o que é que o orientador está a fazer? E por que é que o orientador não fez o mesmo trabalho que eu posso fazer? Assim, diria que, tendo em conta o facto de o estudante ser o estudante, o orientador é responsável e a universidade é responsável por permitir que o orientador faça este trabalho. Assim, há vários exemplos onde há demasiados estudantes para orientadores ou os orientadores não têm o tempo, a ajuda ou o apoio para fazer este trabalho, quando não lhes é dado um avanço profissional, etc. Assim, por exemplo, se está a supervisionar um estudante que está a escrever em inglês mas não é um anglófono nativo, então há várias competências específicas de que o orientador precisa para ajudar esse estudante a aprender a escrever em inglês, por exemplo. Mas se o estudante de doutoramento está a cometer fraude, fraude na investigação, fraude nos dados, fraude nos dois em conjunto, então temos que mudar da área do estudante enquanto estudante para área do estudante enquanto "praticante" e aí a universidade é responsável por gerir isso. Isto responde à sua pergunta? Mas penso que estudantes de doutoramento são muito difíceis porque estão entre os dois.

Luís Adriano Oliveira: Voltarei à sua intervenção, Michelle. Acrescentou algo que é, a meu ver, extremamente importante. Essa capacidade de autorregulação na comunidade científica, e é uma verdade. Aquele que faz algo "não-ético", pode talvez fazê-lo uma vez, mas não o vai fazer regularmente, porque é rapidamente descoberto. E uma vez que é descoberto, bom, é o fim e não falemos mais, será banido do sistema, muito simplesmente. Quanto à motivação para a ética, dou-vos... não quero apresentar-me como um exemplo, porque não é correto, mas, tenho vindo a orientar já há algum tempo uma disciplina que se chama, ministrada aos estudantes de todas as nacionalidades que vêm para a Uiversidade de Coimbra, na Faculdade de Ciência e Tecnologia, que se chama "Research Design and Methods"... e então, esta disciplina, não é totalmente centrada 
na ética. Não se chama "ethics on scientific research" etc. Não, não é isso. É uma disciplina sobre como fazer, porque falávamos há pouco... Bolonha acelerou tudo, agora é preciso fazer as coisas muito rapidamente. Assim, frequentemente, os estudantes sentem-se perdidos, verdadeiramente. Espera-se que façam investigação sem ter o hábito, as bases, o que quer que seja... logo estão perdidos. Assim, uma disciplina como esta "research design and methods" tem uma grande recetividade da parte dos estudantes. E eu entretive-me a fazer, falava com colegas recentemente, diverti-me a fazer conferências sobre o tema "como abordar o problema", a "problemática da investigação... como fazer uma tese, "como fazer isto e aquilo". E juro-vos, as salas estão muito mais cheias que neste instante... por estudantes. Mais ocupadas que agora. E assim, pergunto-me, se aproveitar, e faço-o, se aproveitar para deixar umas noções de ética, ao mesmo tempo que faço considerações sobre a revisão bibliográfica etc., tudo o que tenha a ver com a investigação... não é que se trate de dizer "não se deve copiar nos exames", não é a esse nível... mas ao nível da investigação, penso que esta mensagem, frequentemente, passa. Mas talvez tenha razão... nunca tentei fazer uma aula sobre a "ética", e ver quantos alunos virão. Isso francamente nunca fiz. Colocaria antes a questão em termos de inclusão da ética de modo implícito em diversos setores do ensino universitário, ou mesmo secundário. Os diferentes níveis, claro. Não sei se está de acordo.

Michelle Bergadaà: Estou bastante de acordo. Também dou aulas de metodologia da pesquisa em doutoramento e efetivamente tenho uma sessão sobre o plágio, inclusive sobre o conflito, porque somos também um mundo de conflitos universitários e os estudantes não sabem gerir o conflito... Assim, ensino-lhes também o conflito, porque... como é que se gere o conflito? Mas... é..., ao mesmo tempo, estamos na urgência, com o plágio, ou fraude científica, estamos numa situação que vai demasiado rápido e desmultiplica-se. Não de todo por haver esta pressão de publicação, mas porque o problema 
é este. Chegamos a um certo momento em que somos obrigados a dizer "OK, há riscos"... há verdadeiramente riscos. Se devesse mudar o nome e, ao invés de chamar a isto "seminário sobre a fraude científica e plágio"..., mudaria. Sou professora de comunicação e colocaria "como ser bem sucedido sem correr o mínimo risco?" Deu-me um título e acabo de tomar nota. Assim, adiro totalmente. A meu ver, como conseguir sem correr o mínimo dos riscos, vai fazer furor. Em todo o caso, muito obrigada.

Paulo Peixoto: Queria colocar uma ou duas questões. Desde logo uma questão diretamente a Cristelle Cotton, que é a seguinte: normalmente, por regra, não obstante os estudantes confessarem práticas de fraude, de diversos tipos de fraude, com valores muito elevados, com práticas muito elevadas, numa lógica participativa, ou seja, quando nós perguntamos aos estudantes quais deveriam ser as reações das instituições, os estudantes tendem a exigir com muita frequência medidas punitivas e medidas extremas... e poucas vezes medidas que sejam mais formativas, por exemplo a predisposição para a frequência de cursos de ética tende a ser muito baixa. O que queria perguntar era se nessa dinâmica participativa, os estudantes da UCL também reivindicam medidas mais punitivas ou se, pelo contrário, houve um tipo de reação diferente. Isto porque... uma questão que a Jude colocou que é a questão da simplicidade... a Jude disse que... os gestores universitários procuram sempre a simplicidade. A fraude e o plágio, muitas vezes, são também um resultado da simplicidade, não é? Os próprios professores, muitas vezes, mesmo quando existem respostas institucionais, quando existe enquadramento institucional, eles procuram a simplicidade; ou seja, a simplicidade, muitas vezes é, ainda que exista um enquadramento institucional, o professor preferir gerir a relação diretamente com o aluno. Pode estar previsto um tipo de sanção, que pode ser disciplinar ou académica, mas o professor muitas vezes sente essa sanção como injusta. Ou seja, se a sanção for sentida pelo 
professor como injusta, como demasiado pesada ou demasiado leve, o professor tende, ele próprio, a gerir a relação diretamente com o aluno. Até que ponto, no caso da universidade de Lovaina, há uma confiança no modo como o sistema está organizado? Por exemplo, um caso transita, e em que circunstâncias, daquilo que são as competências do professor para as competências do vice-reitor? Porque nós poderíamos aplicar isto um pouco ao contrário; ou seja, se nós... pegássemos na lei de Murphy da negligência, não é, o que é que acontece muitas vezes? Acontece aquilo que a Michelle referiu há pouco, que a Jude referiu, que é, por exemplo..., um outro exemplo, num doutoramento, a negligência é do orientador ou é dos membros do júri que não leram a tese em devido tempo, e depois só se dão conta do plágio na véspera ou no dia? Não estou a falar de nenhum caso concreto, mas... estas coisas acontecem. $\mathrm{E}$, nesses casos também, é demasiado tarde para ativar as reações institucionais, ainda que elas existam... e depois, mais uma vez, o que é que acontece? Precisamente o que a Jude acabou de referir: a instituição não tem coragem de pôr em causa os seus docentes, não tem coragem de pôr em causa os processos de atribuição de diplomas, e daí que eu, enfim, concorde e reitere mais uma vez que é absolutamente necessário construir estas políticas sobre a relação pedagógica e, a minha opinião muito concreta, só para terminar, é também essa; ou seja, eu também tenho hoje muitas dúvidas que os cursos exclusivos e centrados só sobre a ética tenham sucesso ou eficácia... mas acho imprescindível que, sobretudo depois de Bolonha, haja uma preocupação em que todos os professores e todas as disciplinas tenham uma pequena parte relacionada com o ensino da ética e da deontologia nas matérias que eles ensinam. $\mathrm{Eu}$ isso acho fundamental.

Público: Tenho uma pergunta dirigida à experiência de Lovaina... e que tem a ver com uma conversa que tive numa ocasião com os meus próprios alunos, numa aula. Eu gostaria de saber se em Lovaina 
notaram, durante as vossas iniciativas de combate ao plágio, que os alunos passaram a encarar o plágio como algo que tem um dano coletivo. Um dano para eles próprios. Eu digo isto porque em conversa... nessa conversa que tive com os meus alunos, fiz-lhes sentir que, quando um colega comete plágio, está a fazer concorrência desleal com os outros. Com aqueles que cumprem as regras e que, portanto, o problema não era só do aluno. Era de todos os outros. E, pelas reações deles, percebi que era algo em que eles nunca tinham pensado: o lado da concorrência desleal provocada por este comportamento disruptivo. E, portanto, gostaria de saber se a vossa experiência de Lovaina mostra que realmente os alunos se apropriaram da ideia de dano coletivo que o plágio também causa e se isso os motiva para agir combatendo essa prática. Obrigada.

Christelle Cotton: Vou responder de maneira conjunta às 3 questões que foram colocadas. Assim, sobre a primeira parte que consistia em saber se os estudantes eram eles próprios a favor de sanções relativamente fortes: sim e não. Os estudantes... trabalhamos também com estudantes representantes... estamos, portanto, perante estudantes que estão já politicamente envolvidos, que estão informados... estamos perante pessoas que têm matéria sobre o dossier que estamos a tratar. Assim, para eles era importante a existência de uma sanção, que possa ser gradual, que possa ser igualmente forte e alcançar a exclusão do estudante, para mostrar que a universidade não valida o plágio, que a universidade se oponha ao plágio. Para eles era verdadeiramente importante passar a mensagem "o plágio não é tolerado aqui... não o aceitamos e damos-vos utensílios para o evitar. Mas se, apesar de tudo, há um caso de plágio, grave...este tem que ser sancionado". Portanto aqui fomos bastante claros com os estudantes, por outro lado os estudantes estavam muito atentos aos utensílios que eram colocados à disposição e a todo o período de sensibilização e formação. Desde o início, com o trabalho que levámos a cabo, o seu discurso era "não queremos chegar à punição 
para punir, queremos que tal sirva para algo". Aqui era mesmo... o seu combate era este. Estávamos convencidos de que o combate era fácil. Sobre a confiança com os docentes, bom, constatamos que temos mais e mais respostas, mesmo informativas, das ações que são levadas a cabo pelos docentes. Portanto, pensamos que o tecido está a ser criado e que a confiança, precisamente neste domínio, avança e... mas não é fácil, porque, efetivamente, as políticas que são levadas a cabo neste domínio estão também ligadas às autoridades existentes, e as autoridades mudam também regularmente. Portanto, agora estamos no mandato durante o qual toda esta política foi levada a cabo. Um mandato que se queria particularmente centrado na lógica da abertura e particularmente da comunicação e envolvimento de todos os atores. Assim, conseguimos efetivamente fazer colaborar os diferentes atores, incluindo os docentes. Hoje quando uma sanção é tomada no quadro de um dossier que foi transmitido por um docente e em seguida por um júri académico, há uma resposta dirigida ao docente e tentamos justificar, ou pelo menos motivar, ao máximo, a decisão que foi tomada... e constituímos também uma jurisprudência, e este é um elemento muito, muito importante e relativamente confortável quando devemos tomar uma decisão. É poder justificar a decisão tomada, também relativamente a decisões que haviam sido tomadas anteriormente e garantir a equidade entre os estudantes. Assim, penso que há sempre professores para os quais é dificil assumir que, "por causa de", entre aspas, o estudante será punido e arrisca a exclusão ou perder o ano letivo... mas a nossa mensagem é "não é por vossa causa, docentes, que o estudante é punido. É por causa dele mesmo e do que ele fez. E vocês têm o dever também, perante o conjunto dos vossos estudantes, e do vosso próprio ensino, de assinalar os casos e... não podemos fechar os olhos”. A maneira como é feita a gestão, deixamos ao docente a possibilidade de fazer uma gestão própria, mas também de procurar apoio em outros níveis de decisão. Depois, evidentemente, haverá, sem dúvida, ainda, docentes que irão gerir 
isto com os estudantes sem passar desse nível. Não podemos chegar à consciência do docente. Isso não é possível. Sobre a concorrência entre estudantes, nunca vi a coisa assim. Talvez porque não há uma real classificação dos estudantes no nosso sistema, não sei se aqui há uma classificação mas... os estudantes recebem os resultados e não há verdadeiramente concorrência entre eles na base. Em contrapartida o que se destacava fortemente nos discursos dos estudantes era dizer que: quando perante um caso de plágio, este deveria ser seriamente tido em conta porque era digno de afetar, também, a imagem do conjunto da universidade, incluindo eles próprios, e que poderia também colocar uma dúvida sobre a qualidade da sua formação, mas não senti que havia verdadeiramente o fenómeno do qual falava há pouco.

Jude Carroll: Posso dispor de alguns elementos úteis. Um é relativo a uma questão do Jacques, colocada há pouco, sobre avaliação. Como é que a Cristelle avalia? Uma das tentações é a de avaliar olhando para o número de casos. Isto quase nunca é uma avaliação útil e... é certamente um longo projeto no qual a Christelle está envolvida e... as universidades implicadas... estão, na verdade, a alterar a cultura da universidade. É uma questão de mudança cultural. Não conheço nenhuma universidade que tenha mudado de "não fazer algo sobre plágio, fraude e cópia" para o sentimento de "temos um sistema ativo que é confiável, eficiente e do qual devemos estar orgulhosos". Não conheço nenhuma universidade que se tenha movido entre estes dois lugares em menos de 5 anos... e o grande desafio é o de manter o projeto em andamento. O grande desafio não é o de colocar em ação os vídeos, as sanções, os sistemas, os registos... isso não é difícil. Toda a gente pensa que é. Claro que é complicado. Claro que leva tempo. O grande desafio é mantê-lo em andamento. Foi dito, todos os anos novos estudantes chegam... todos os anos temos que os treinar/ensinar de novo. Esse é um verdadeiro desafio para as universidades. E quando as universidades centram 
a atenção nesta temática, o problema é que, às vezes, pensam, está feito. Resolvemos o problema e, assim, o real problema é mantê-lo em andamento. E... o lado deveras criativo é encontrar avaliações que digam o que queremos ouvir, a informação de que precisamos. $\mathrm{E}$ aquilo que realmente queremos saber é: são os nossos estudantes mais capazes de fazer o que queremos que eles façam? Estarão mais propensos a agir como queremos que ajam. Estamos nós a melhorar na identificação dos e na gestão dos casos? Casos de má conduta, de plágio, de cópia... Se os números começarem a subir um pouco, as pessoas não devem ficar preocupadas... devem ficar satisfeitas. Mas não devem ser ingénuas ao ponto de pensar que estão a dar conta deste problema de subdenúncia. Assim, deve continuar.

Jacques Hallak: Talvez sobre esse ponto, se me for permitido, isto é... eu não usei a palavra avaliação mas sim monitorização... e monitorização do processo em si... estou a falar do processo. Por falar nisso, devemos dessacralizar o tema do plágio. Se ouvirmos o que a Christelle disse, de 4000 estudantes que chegam todos os anos, ela disse... tivemos conhecimento de, talvez 20 casos... de que é que estamos a falar? 20 casos em 4000 é nada. Não somente a nível estatístico mas também em termos administrativos... é nada, tão-somente nada. O custo de gerir estes valores seria demasiado alto sendo o objetivo resolver estes 20 casos. O custo não é alto se mudarmos a cultura da universidade.

Jude Carroll: E 20 é provavelmente uma estimativa por baixo.... Jacques Hallak: Ora, esse é o ponto...

Luís Adriano Oliveira: Gostaria de retomar aquilo que dizíamos há pouco com a Michelle sobre a motivação para o ensino da ética. Ensino que não é provavelmente a palavra adequada para o momento. Vou colocar-lhe a si, Christelle, uma questão: Suponhamos que sou um dos 4000 alunos que entram pela primeira vez na universidade de Lovaina, que tem um prestígio enorme ao nível da ética universitária, sei... porque tem um site que é muito, muito visitado na matéria... 
suponha que sou um dos 4000 que se apresenta na universidade pela primeira vez. Que estratégia adotará para me motivar a fazer uma reflexão sobre problemas de ética? Como conseguirá despoletar a minha atenção, interesse e motivação para o problema da ética? Porque a priori não tenho esta consciência, estou-me nas tintas.... há aulas sobre a ética? Há clubes?

Christelle Cotton: Há aulas de metodologia, antes de mais... que abordam a questão da ética e que são propostas mesmo antes de os estudantes entrarem na universidade. Durante o verão... que são por um lado disciplinares... mas que englobam também uma parte de metodologia, e logo aí certos aspetos são abordados. Depois há módulos que são propostos aos estudantes à entrada.... e é também um dos objetivos da "jornada" do mês de novembro, de ir ter com estes estudantes e informá-los. Os estudantes recebem no início do ano académico uma carta personalizada que menciona, entre outras, os módulos de metodologia que são propostos... Assim que os estudantes se inscrevem nas bibliotecas para fazer o cartão para o empréstimo de livros, há novamente uma sensibilização e uma promoção destes cursos de metodologia... E a jornada do mês de novembro, na qual os estudantes dos anos superiores vão ao encontro dos estudantes mais novos visados por estes cursos de metodologia. Numa abordagem repetitiva de proposição temos também uma grande parte dos nossos professores que, no início do ano, como diziam há pouco, inserem nos seus cursos aspetos de ética. Ainda não chegámos ao ponto de dizer que um curso de ética deve fazer parte integral do primeiro ano dos estudantes e deve ser um curso acreditado. Ainda não pensámos na matéria mas não excluímos a hipótese. Sobretudo na nova paisagem do ensino superior que se está a desenhar na Bélgica...10 anos depois de Bolonha, temos agora uma nova estrutura em curso ao nível do ensino francófono e que nos vai deixar mais espaço para a construção de programas. Até ver estávamos muito limitados. Agora 
vamos chegar a um espírito de módulos, fornecedores de créditos ou não... Assim, a ideia ganha forma...

Luís Adriano Oliveira: Esta disciplina que poderia no futuro ser colocada em ação, teria um carácter de obrigação?

Christelle Cotton: Talvez. Em todo o caso, os estudantes com quem discutimos não se opõem a que seja obrigatório. Eles estimam que é mesmo uma mais-valia... porque no certificado, recebem a lista dos créditos obtidos por cada disciplina e ter um curso de ética é algo que os estudantes entendem como uma mais-valia no seu curso. E isto em todos os cursos. Sentimos os estudantes do setor médico menos sensíveis à questão... mas na maioria dos setores vemos que os estudantes, sobretudo do primeiro ano, estão muito menos.... eles estão muito mais na ideia deontológica ligada à disciplina, mais do que na ética de funcionamento e metodológica.

Jude Carroll: Só uma pequena ideia sobre... penso que é talvez útil ter uma disciplina sobre ética, mas não conheço nenhuma prova... onde os estudantes... isto é uma atitude, é um agrupamento de valores e ideias. E se se perguntar, como é que os estudantes aprendem a trabalhar com estes valores? Como é que eles obtêm estes valores? Não há quase nenhuma prova de que se possam ensinar atitudes e crenças, mas podem criar-se oportunidades onde os estudantes possam refletir e pensar. Falar entre eles sobre a forma como se comportam e o que vão fazer e como o vão fazer e podem gradualmente inserir-se nesses valores que queremos que adotem. Uma das razões pelas quais me envolvi na reflexão sobre plágio e fraude foi um excelente artigo, publicado em 1995, que analisava os comportamentos e valores dos estudantes. O que é importante? Quais são os valores éticos que seguem? O facto de que não sigam a nossa ética, não quer dizer que não sigam valores éticos. Eles têm diferentes atitudes, crenças e valores e para mudar de um agrupamento para outro é responsabilidade do estudante fazer isso. E é uma responsabilidade do Professor criar 
o ambiente onde essa mudança possa acontecer. Não tenho a certeza que sejam necessárias aulas, mas estou certa de que a reflexão, a discussão, a interação... e pensar sobre os seus próprios valores e crenças é o que é necessário que aconteça.

Christelle Cotton: Sobre a questão das aulas... nós trabalhamos muito também nas questões de transição entre o ensino secundário e o ensino superior no nosso domínio de atividades e é uma questão que trabalhamos também com os estabelecimentos secundários desde, faz agora, um ano... porque nos apercebemos que o estudante que chega no primeiro ano está completamente impreparado e que passa do nada ao tudo. E estamos assim, também, a tentar desenvolver estratégias com o ensino secundário, de construir pontes, não somente nas questões éticas... mas pensamos que há aqui uma parte da educação a ser desde logo trabalhada.

Luís Adriano Oliveira: Jude, só um pequeno comentário sobre o que disse, se posso. Penso que a ética é de facto um valor universal, em contraste com questões como a moral, que é muito mais subjetiva e muito mais dependente geograficamente e por aí fora. E é talvez por isso que penso que refletir sobre a ética em geral, é algo que, intrinsecamente, tende a ser universal, do meu ponto de vista. É o que a distingue da moral e de valores como esses.

Jacques Hallak: Só uma pequena ilustração para a Jude. Na Austrália, num Estado da Austrália... no ensino do código de conduta para professores, fazem exatamente o que a Jude está a dizer. Isto é, com vídeos, etc... colocam problemas éticos aos professores-estudantes e lançam o desafio de como resolver estes problemas éticos. Como interagir se, como professor, está frente a um grupo de estudantes. Como resolver este problema? E... há aqui uma experiência muito interessante e recomendo... e é por isso que a refiro, porque a achei extremamente convincente e tem vindo a ser usada na preparação de professores no tema "código de conduta e ética dos professores". Só isto. 
Michelle Bergadaà: Muito obrigada por esta apresentação. Queria que os colegas de Coimbra encarassem o que vou agora dizer como um símbolo de respeito e não porque nos pediram para estar aqui para fazer avançar o debate. Assim, vou agora mudar de "chapéu" e só vou falar de metodologia. Tenho um pouco de dificuldade, tenho que dizer, para já, quanto a uma investigação científica quantitativa. Damos opiniões pessoais que são certamente válidas, mas que devem ir para lá da apresentação científica. Queria relembrar o que foi disto esta manhã... que, antes de mais, quando nos reportamos a algo tão sério como a ética, é necessário distinguir muito claramente as definições conceptuais entre o plágio, a fraude e a cópia no exame. Quando percebemos bem o conceito fundamental que está por trás, em termos de ética, aí talvez possamos dizer como é a cópia no exame face ao plágio, mas é preciso antes de mais defini-las. O problema que tenho... é que eu sou tanto investigadora qualitativa quanto quantitativa. As análises qualitativas pedem uma análise por indução. Portanto, não 5 ou 6 exemplos. Uma verdadeira análise por indução pode ser feita tanto com softwares ou manualmente, mas é uma análise diferente do quantitativo. Portanto, não irei tratar da última parte que, a meu ver, merece aqui uma verdadeira investigação, se têm bastantes, verbatim como este, que deve ser tratado com especialistas por indução da análise qualitativa. Agora para a parte quantitativa. O que resta fazer a meu ver? Por ora, aquilo que apresentaram é excelente mais muito descritivo. Queremos chegar à parte analítica, certo? É verdade que não acredito, como vocês, nas variáveis antecedentes, do género, da disciplina, etc. Descobrimos ao longo destes 2 dias que há outras variáveis antecedentes a ter em conta e para simplificar vou falar das variáveis que entram.... "internal locus of control"... será que aquilo que fazemos é culpa de pessoa externa ou há uma outra culpa e responsabilidade? Há variáveis antecedentes que talvez não tenham medido e que 
merecem ser medidas. Nas variáveis antecedentes ligadas ao "locus of control" externo, disseram-no, "eu, estudante, tenho a sensação de que a carga de trabalho é excessiva. Tenho a sensação que são injustos comigo ao pedir-me tanto trabalho". Foi ainda a Jude que disse esta manhã: "tenho a sensação de que posso enganar o sistema porque o sistema não é objetivo comigo. A disciplina pede-me em demasia. Estou em medicina, pedem-me demasiada pressão de tempo em pouco tempo, não é a mesma coisa. Sempre no "locus of control" externo. Não há nenhum controlo. Toda a gente copia, por que é que eu não o faria? Então podemos assim listar 5 ou 6 fatores antecedentes ligados ao "locus of control" externo. É o sistema. Agora no "locus of control" interno, tenho o sentimento, é só em "Escala de Likert", tenho a sensação de que humilharia a minha família se copiasse. Tenho a sentimento de que não me reconhecerei a mim mesmo se plagiar. Isto é "locus de controlo interno". Tenho o sentimento que mereço mais do que copiar. Trata-se da apresentação de Lovaina. É a outra tradição. Uma vez que vocês têm o vosso bloco de variáveis antecedentes ligado ao locus de controlo externo e interno, fazem simplesmente uma análise multivariada. Não somente um teste mas também uma análise multivariada e terão um super-modelo. Não inventei nada. Só disse, as variáveis que foram dadas por uns e pelos outros durante estes 2 dias e eu só, se quiserem, os modelos são fáceis de fazer. É uma análise muito fácil de fazer. Estou convencida que se tiverem os meios e os investigadores, é a etapa extra que é necessária se tiverem os dados. Ou seja, duas análises: na análise qualitativa, uma análise mais estruturalista e do outro lado, também estruturalista mas com uma análise feita a partir de verdadeiras variáveis antecedentes. Porque na vossa análise vocês estão na perceção. Estão unicamente no subjetivo. O estudante diz, penso copiar. Não são factos objetivos.

Aurora Castro Teixeira: Concordo que estas análises são muitas vezes muito descritivas e... muito frias. É óbvio que a análise, mesmo 
das respostas dos estudantes, dos que comentaram, é uma análise muito rica e que pode ajudar a entender e a reforçar ou não aquilo que são os resultados dos modelos... mas concordo perfeitamente com o meu colega quando diz que é necessário ir buscar e tornar mais rigorosos os conceitos que estão subjacentes à ética, basicamente..., e, portanto, há muito trabalho ainda a fazer e agradeço bastante as sugestões que entendo que são muito interessantes para o desenvolvimento do trabalho.

Luís Adriano Oliveira: Não é tanto para... confesso que com tanto material e... consistente material é sempre óbvio que é possível criticar a forma como se constroi material desta natureza. Mas eu confesso que estou ainda um pouco confuso. Estou só a tentar desencadear as hostilidades, por isso vou avançar com um ponto ou dois mas que não seria necessariamente, que se refletisse um pouco mais... aquele por onde começaria. Só em termos provocatórios, a desconfiança na capacidade da instituição para reagir a uma eventual denúncia. Eu julgo que esse aspeto é muito real. Reflete uma realidade muito... tenho pena de o dizer... muito brilhantes colegas estrangeiros.... temos muita tendência para ficar muito chocados com o que é denunciado e amanhã já não nos lembramos. Isto é algo que tem... vive regularmente fora de portas... de um ponto de vista cultural que nós devemos fazer um esforço enorme para corrigir, como... também sermos mais pontuais. Culturalmente temos inúmeros valores mas..., provavelmente, também temos algumas fragilidades que se as admitirmos é interessante que possamos trabalhar um pouco sobre elas e tentar reagir. De facto, penso que... se olharmos para a tradição de resolução de problemas que tenham decorrido de denúncias dentro do tecido universitário, há uma tendência enorme para escamotear os problemas até para... não correr o risco de que 
o prestígio da instituição seja posto em causa. É uma espécie de um corporativismo que de algum modo traduz uma espécie de cobardia. Se mexermos muito no problema as consequências podem ser imprevisíveis. Portanto, há uma certa insegurança..., isto é provocatório..., que leva talvez a não reagir com a capacidade de reação que a gravidade do problema eventualmente aconselharia. Por outro lado, há também, ainda em relação à capacidade de reação, há uma certa desconfiança quanto à capacidade real que a instituição tem de evitar medidas de retaliação. A proteção, ou eventual ato de denúncia, depende.... há falta de denúncias... problema grave... a forma como se constroi uma denúncia com certeza que não consistirá em fazer rebentar uma bomba. Uma graduação de formas de reação... se a denúncia passar a escrito, os mecanismos de proteção quanto a eventuais ações de retaliação, mais uma vez entre nós... julgo que carecem de reflexão. Levantava só outro aspeto... pareceu-me que foi mencionada... diferença entre géneros a vários níveis. Bom, isto enfim... é uma coisa que nós não podemos controlar... os géneros são o que são... há homens e há mulheres e é o que é... do ponto de vista pessoal, creio muito que essa questão tem muitíssimo a ver com a cultura local. Portanto, há muita coisa que nós podemos e devemos fazer para que essas diferenças não sejam tão acentuadas. Nós, no fundo, somos muito mais parecidos do que intrinsecamente aparenta uma análise destas, a verdade é que do ponto de vista cultural, a prática não permite traduzir essa parecença, a meu ver.

Jacques Hallak: Antes de mais gostaria de dizer a que ponto estou satisfeito com a densidade e riqueza da informação que connosco foi partilhada. Peço desculpa, primeiro, porque conheço muito mal o sistema de ensino português... e segundo, tendo em conta a densidade da informação, creio ter absorvido elementos muito coerentes e coisas menos coerentes... mas deve-se ao facto de haver demasiada informação que não podia digerir nos tempos que me foram impostos. Assim, gostaria de fazer três comentários e, perdão, se estes 
não são pertinentes: o primeiro é, se interpretei bem os resultados apresentados, há uma falha do modelo transitivo/transitório do qual falei ontem. Isto é, do modelo onde há informação... sobre os riscos... deteção e depois sanção. E, este modelo, não funciona. Visto que... sobretudo... o que me chamou particularmente a atenção... é... o que encontraram ao nível da ética. Fizeram uma reflexão que agrupa tudo o que vi noutros países: é a ignorância do corpo docente, da realidade do funcionamento da instituição na qual trabalha. Há quem assine mesmo contratos e não saiba o que há no contrato, mesmo quanto ao seu código de trabalho ou código profissional. Não falo do código deontológico ou ético. Esta é a primeira observação. A segunda é... devo admitir que tenho alguma dificuldade... devo dizer que à partida sou de formação estatística... A minha primeira formação foi o INSEE e sou fraco no que toca a trabalhos estatísticos baseados sobre percepções e opiniões... sobretudo quando cruzadas entre elas. Devo colocar a questão porque nos pode levar muito longe. Mas, estaria muito interessado em saber se fizeram um trabalho de normalização dos dados, de estandardização dos dados, de divisão por tipos, enfim... de tornar os dados... de passar do ordinal ao cardinal..., etc... para poder avançar nas análises estatísticas. Não coloco a questão... é uma questão que coloco a mim mesmo, porque tive muita dificuldade, francamente... porque são coisas que são ao mesmo tempo opiniões e declarações... não é a mesma coisa. Declarativo 2 anos depois... e opinião 2 anos antes. E logo, encontramo-nos dentro de coisas assaz heterogéneas. O terceiro comentário é mais uma questão: citaram 3 países... Portugal, Espanha e Brasil e cruzaram 2 abordagens, com inquéritos presenciais e online. Estaria interessado... será que fizeram uma comparação entre os dados online e os dados presenciais e se tal foi convincente... se encontraram coisas significativas do ponto de vista da coerência... e da robustez dos resultados e conclusões. E enfim... é menos uma questão mas mais um desejo... penso que este trabalho é muito importante... não é um trabalho... que deve 
ficar entre as mãos dos investigadores... mesmo que haja desacordos na equipa de investigação. É um trabalho que deve ser exposto à comunidade universitária para começar, e depois ao nível da política de ensino superior....porque há bastantes elementos que tocam na política de ensino superior, na estratégia de formação, na gestão do tempo dos docentes e estudantes, no problema das medidas de incentivos. Não falo de sanções... de penalidades... de colocar na prisão ou de lançar pela janela as pessoas... mas de definir estratégias pedagógicas de gestão do tempo e de gestão do ensino superior que são interpeladas por estes resultados, pese embora o facto que possamos ter reservas... eu não as coloco porque não sei... podemos ter reservas sobre algumas das conclusões, assim... o meu último comentário é mais o comentário de um homem político que me diz... trabalho de investigação, central, importante... que interpela... será que o vosso trabalho... o que é que acontece depois? Onde é que vamos depois com este trabalho? Se o adaptarmos a um relatório é bom mas não é... será que vamos ter um relatório ou vamos mais longe? Isto é, está previsto que este trabalho possa ser resumido em 2 páginas? Porque os ministros não têm tempo para ler mais que duas páginas. E talvez 10 páginas para os presidentes de universidades, no qual se diga... fizemos este trabalho, discutimos, etc.... mas deste trabalho surge um certo número de questões que merece ser tratado ao nível da política de ensino superior. Não sei se estou a ser demasiado ambicioso nesta última reflexão, mas penso que tocam em muitos pontos que são.... que são... isto é, toda a análise que fazem por disciplina é fundamental, mais o trabalho... eu fiquei muito surpreendido, digo-vos francamente, toda a rubrica "formação dos docentes"... interpelou-me bastante... No que toca à medicina não me surpreendeu muito. O direito foi muito interessante. Não é o que está em primeiro lugar, mas muito interessante. Acredito que aqui, vocês têm uma série de dados... que não são reunidos para serem organizados num belo dossier de investigação. É importante refletir 
e perceber... o que surge daqui? Esta investigação tem uma função social, uma função política... tem... e talvez tenham já tudo isso em mente... mas como convidado estrangeiro que se sente lisonjeado com o facto de estar aqui, gostaria de obter informações, seja agora, seja mais tarde sobre o devir deste trabalho de investigação face à política de ensino superior em Portugal.

Aurora Castro Teixeira: Começaria precisamente pelo género. Porque de facto da forma como eu falei, não foi muito feliz... eu concordo com o que disse, que há de facto perfis diferentes entre os géneros que nós podemos e... agora... é uma temática muito complexa porque é cultural e demora muito tempo a alterar comportamentos que estão muito inseridos em termos de comunidades, em termos de interações. Portanto eu percebi que a minha mensagem foi percebida no sentido de que é uma fatalidade... e concordo com o que disse nesse aspeto. Relativamente à capacidade das instituições em vários... feliz ou infelizmente, na minha óptica infelizmente, porque constatei aquilo que nós todos acabámos por sempre dizer, de facto a capacidade institucional é muito grande e... nos vários episódios em que me vi envolvida... em termos de pessoa externa a comentar episódios de fraude... e que era necessário para a instituição existir uma comissão para avaliar em que medida e em que termos pudesse acionar a prática de plágio e... numa primeira fase as instituições mostram-se muito preocupadas porque... e normalmente porque os media estão em cima da instituição e portanto... há que urgentemente mostrar que a instituição está a fazer alguma coisa para acautelar... ou pelo menos tratar o problema. Mas, logo que os holofotes mudam, as comissões que são formadas e as respetivas conclusões são colocadas na gaveta... e portanto isso é... das várias que eu já estive, e não foram poucas, acontece sempre a mesma coisa: a primeira reunião é para ontem porque nós temos que dar uma resposta, mas passado dois dias já ninguém se lembra, e portanto os resultados que daí advêm são nulos em termos práticos e isso acaba por reforçar, a quem 
pratica o ato, a ideia de que nunca vai acontecer nada e, portanto, é pior a emenda que o soneto. E o que é que nós temos que fazer. No caso português, grande dificuldade nossa, queremos fazer muito de uma só vez... em vez de atuar em práticas simples, procedimentos simples e que toda a gente saiba... e às vezes é preferível atuar pequenino mas... ser claro naquilo que se possa fazer... do que querer fazer uma lei que cubra tudo que no fim não cobre nada. E portanto esta é a minha sugestão. E, respondendo também ao colega, nesta última parte, o que é que nós podemos fazer, por que é que estamos tão preocupados se temos os dados? O que é que vamos fazer com os dados? Da minha parte... que tenho andado um bocado isolada, tanto em equipa quanto em relação aos colegas de Coimbra, mas... agora que nos estamos a conhecer é um primeiro passo. Eu tento, de alguma forma, junto de tudo o que é, imaginemos... tenho estado a mostrar os resultados do trabalho junto das comissões de ética de saúde... junto das várias escolas. Todas as escolas que eu contactei para pedir colaboração, no sentido de fazer chegar o inquérito aos alunos... A posteriori, ofereci-me também, voluntariei-me para ir mostrar os resultados e para estar a conversar com os docentes, sobretudo, mais do que propriamente com os estudantes, sobre as questões... sobre o que é que estava a acontecer para a tal informação. É óbvio que quando estamos nessas comissões as pessoas mostram-se muito preocupadas, mas é um grupo relativamente reduzido de pessoas e normalmente as pessoas com responsabilidade nas escolas não estão lá. O que também dificulta esse trabalho. Para além desta sensibilização e divulgação é óbvio que em termos das autoridades de política - aliás, os colegas de Coimbra têm sido bem sucedidos nesta semana... têm surgido notícias sobre esta temática, que acaba por ter algum impacto social... - temos que fazer mais pressão sobre as instituições políticas por via institucional. Mas, no caso português, a classe política não é propriamente a classe mais exemplar em termos daquilo que são as práticas de plágio e as práticas das cópias, 
o que também dificulta, muitas vezes, uma conversa. E a ideia que passou, de que é preciso um texto muito curto e simples, etc... Mas, mesmo com esse texto simples, há sempre outras ou outros temas mais prioritários... que fazem com que estas questões sejam relegadas um bocadinho para segundo plano. Mas, dito isto, não quer dizer que deixemos de fazer e de, sempre que possível, nas várias sedes, nas equipas reitorais, etc. fazer pressão para que as instituições mudem um bocadinho. Só para finalizar chamo a atenção de uma coisa... que é... a minha amostra tem incluídos estudantes do $1^{\circ}, 2^{\circ}$ e $3^{\circ}$ ciclos..., o que faz com que as questões de preponderância do plágio surjam mais elevadas no meu estudo que no vosso... porque no vosso quando vocês seguem os estudantes... os estudantes estavam na licenciatura, possivelmente agora estão no mestrado e doutoramento, e dão mais importância às práticas mais dos trabalhos, mais associadas ao plágio do que propriamente às outras quando estavam no $1^{\circ}$ ciclo. Possivelmente há aí um efeito, de, quando nós estamos no mestrado ou doutoramento a componente de investigação ou trabalhos começa a ser mais relevada do que propriamente a cópia em exame. E nós achamos mais grave porque somos confrontados com a realização da dissertação, dos trabalhos, de ter essa concorrência um bocadinho unfair.

Filipe Almeida: Peço para responder ao Professor Jacques Hallak sobre a valência do modelo. Pessoalmente acho que estamos a viver o fim de um tempo. O que significa também que estamos perto do início de outro. E a instituição universitária terá que se repensar profundamente, e estes estudos que estamos a fazer agora e este encontro que estamos a ter aqui é bem representativo disso. Concordo inteiramente com a visão do Professor Hermano de que é necessário regenerar a universidade; ou seja, gerar uma nova universidade, porque esse sistema está moribundo. Este assunto é absolutamente fundamental. Sem bondade e inteligência não há saltos qualitativos na humanidade. E a fraude académica ataca precisamente estas duas 
coisas: a bondade e a inteligência. Este assunto é reconhecido por todos como sendo essencial e este auditório está praticamente vazio. É um dos sinais do fim dos tempos. E eu pessoalmente estou convencido que esta falência vai gerar um novo desenho. Nós estamos muito preocupados em tentar ajustar estas preocupações ao sistema que tem 30 anos. Portanto, o sistema tem que mudar. Provavelmente vai mudar até a forma como a universidade se organiza e a forma como os docentes atuam dentro da própria universidade. A universidade não nasceu assim. Os docentes davam aulas em casa no séc. xviII... e quem lhes pagava os salários eram os alunos, não era a Universidade, até serem catedráticos. E era para o aluno que existia. Ou seja, a universidade também se transforma. E este modelo está esgotado com o advento das novas tecnologias que não conseguimos combater. Com o derrube das fronteiras entre pessoas, entre países, e, portanto, desse ponto de vista, há uma falência mais geral. Nós somos apenas mais um elemento, estamos a fazer este estudo porque temos estas preocupações. Estou convencido de que daqui a 10 anos elas estão completamente desatualizadas, porque alguma coisa se transformou profundamente. Estou a tentar devolver uma resposta igualmente provocadora. Embora seja exatamente aquilo em que acredito... e que se consolidou com o que eu tenho ouvido do Professor Hermano. Em relação ao inquérito online vs presencial... nós não comparámos as diferenças porque não usámos esse método para a mesma amostra. A amostra portuguesa foi estudada em papel, presencial, e as outras, online. Portanto nós não comparámos amostras iguais... isso não aconteceu. Relativamente ao que o Professor Luís Adriano disse, vou só fazer dois comentários pequenos. Relativamente ao que está aqui exposto, os docentes sentirem que a instituição não responde à denúncia e terem medo de fazer essa denúncia... talvez isso seja, entre muitas outras coisa, fruto da dimensão do nosso país. Nós somos um país muito pequeno e... todos nós... ou somos primos ou somos vizinhos... é pequeno 
demais e falta-nos escala. Desse ponto de vista a comparação com o Brasil é interessante porque é um país onde essa proximidade não existe e necessariamente a realidade é diferente. Portanto, estou a avançar com... uma, só mais uma ideia para o ar. Relativamente aos homens e mulheres não tenho nenhuma explicação razoável... para um debate académico. Mas eu estou convencido que para estas duas questões, a contribuição dos antropólogos pode ser essencial para tentar entender por que é que, de facto, tanto no caso dos alunos como das mulheres, em Portugal, as mulheres são sensíveis à fraude, veem mais fraude que os homens.... os homens são mais predispostos a cometer fraude e menos predispostos a denunciá-la... e isto é transversal. Seja qual for a idade e o estatuto... seja professor ou seja aluno. E eu aproveito a deixa, que temos antropólogos na equipa de investigação... e eu, abria também a possibilidade de os meus colegas, que têm certamente opiniões mais interessantes do que eu sobre isto, possam também... responder a estas questões, para eu não esgotar as questões que foram colocadas. Vamos ouvir mais... mas o meu compromisso é que eu já não respondo. Eu peço aos colegas da equipa que ajudem... e também contribuam.

Público: Tenho que fazer mais um comentário do que uma pergunta. Se nós pudéssemos elencar todas as fontes externas de influência sobre o comportamento fraudulento dos alunos... no âmbito de sistemas de avaliação... isto porque, como sabem, a fraude pode ser vista como um comportamento estratégico em resposta a este ambiente de avaliação... um aspeto fundamental, que é ativamente negligenciado pelas instituições portuguesas, é a questão de falta de transparência naquilo que diz respeito aos critérios de avaliação e correção dos trabalhos, provas, etc. E o motivo pelo qual isso é relevante para a questão da fraude... é porque esse sigilo a respeito de como a nota é construída... nutre um ambiente de desconfiança sobre a honestidade do corpo docente. Esse mesmo corpo docente que, em seguida, constroi um discurso pregando um nível de padrão 
moral que os próprios alunos reconhecem. Em benefício desse argumento, gostaria de prevenir uma objeção que é muito comum quando se levanta qualquer sombra de dúvidas sobre a ética dos professores. Que é, se os alunos estão cientes de comportamentos antiéticos por parte dos professores, porque é que eles não denunciam? Por que é que eles não utilizam os ditos canais institucionais? Por um motivo óbvio... é por receio de retaliação. Mas o motivo menos óbvio é que... o próprio sistema não prevê nenhum tipo de evidência documental ou prova ou qualquer tipo de documento que possa dar suporte à queixa do aluno. E, como sabem, em Portugal, os alunos não ficam com a posse das provas. Então eles não têm como comparar com os seus pares os critérios. Da mesma forma, são raros os professores que divulgam os critérios de correção objetivos dos trabalhos e exames quando divulgam as notas. Ou seja, ao aluno só lhe resta a sua palavra quando algum excesso é cometido contra si e... essa é muito facilmente desacreditada dentro deste sistema, de modo que é um incentivo a nem tentar combater esta injustiça e a buscar outras estratégias, entre elas a fraude, para tentar sobreviver dentro de um sistema de avaliação que se apresenta mais como um oponente do que como um aliado do aluno. Esse é o meu comentário.

Michelle Bergadaà: Respondo ou faço um comentário, Filipe? É muito interessante. Estou de acordo com o que foi dito. Agora, voltando à falha do sistema. Tudo o que apresentámos, uns e outros, advem de uma abordagem analítica do problema. Mesmo eu, quando falei de normas ontem... as normas são uma lógica analítica que está dentro do sistema que está fora do sistema. Quem é o outsider? O problema é que, quando se atinge uma tamanha quantidade... para além dos $30 \%$ de atores no sistema que dizem cometer fraude ou protegê-la, não podemos mais utilizar uma abordagem analítica. Falou também de globalização e mundialização. Existe na Colômbia um pequeno povo de índios que se chamam os Kogui e os Indios Kogui sobrevivem porque têm uma lógica diferente da nossa. Não 
excluem os fraudulentos ou batoteiros, não os colocam na prisão, isolados, mas colocam-nos precisamente no centro da sociedade, porque consideram que se há um ladrão, um malfeitor... é uma falha coletiva. A partir desse momento já não serve de nada, depois destes dois dias de debate, tentar encontrar quais são talvez as causas... tentar criar regulamentos... mas acreditar que com regulamentos vamos indagar todo o fluxo... essaa barreira que já foi transposta. Não vamos maquilhar sistemas que têm mais de $30 \%$ de "batoteiros" entre eles. Se há $30 \%$ de estudantes fraudulentos, há $30 \%$ de professores fraudulentos. Os homens são os mesmos, qualquer que seja a sociedade. Se estamos a $30 \%$ é preciso admitir que temos que mudar. Portanto é isso, Filipe... a solução do futuro não está no analítico... podemos tentar compreender as razões, mas está numa abordagem muito mais holística do sistema e de admitir que é todo o sistema que é desde já fraudulento... e que a fraude deve ser vista de outra forma. Não digo que não seja necessário ser analítico, sou terrivelmente analítica... mas é preciso saber quando é preciso parar de ser analítico e mudar de modo de pensar. Se falamos do sistema, paramos de ser analíticos. Se falo do indivíduo, então sim, sou analítico, porque posso encontrar as razões, os motivos e posso, efetivamente, criar modelos. Mas se quero falar do sistema, então torno-me holista. Penso que é este o futuro. Mas é uma proposição, não é de todo uma certeza.

Aurora Castro Teixeira: Relativamente às questões dos alunos e da falta de transparência, é, portanto, um problema real. E várias escolas, pelo menos a escola onde eu leciono, desde há 3 anos a esta parte, todos os docentes são obrigados a publicar os critérios de correção, os tópicos pelo menos... e todos os alunos... portanto, existem inclusivamente períodos onde os testes têm que ser mostrados... têm que ser... se os alunos assim o entenderem, terão que ser discutidos. Isto é apenas um pequenino... não quer dizer que não vá existir o mesmo problema que tu referiste, que é, obviamente, há aqui uma relação de poder... que pode ser mais explícita ou mais 
implícita e que os alunos, regra geral, estão na parte mais frágil... seja... mesmo quando podem pedir revisão de prova. Podem... mas... na verdade não o fazem com... ou receio de retaliação... ou consciência de que o que possam fazer não vai trazer, a não ser muito desgaste psicológico, não vai trazer efeito prático. Não obstante, há também comportamentos e há tipificações. Há docentes que são sistematicamente conhecidos e reconhecidos pelos seus pares e também pelos estudantes como tendo comportamentos atípicos... e que poderiam perfeitamente ser... pelo menos mais chamados à atenção... e poderem corrigir o comportamento mas... na minha visão... as nossas práticas individualistas, não o permitem. Quando digo práticas individualistas quero dizer do ponto de vista quer dos docentes, que não querem se meter... quer do ponto de vista dos estudantes, que não se organizam de forma cooperativa para resolver um problema que é de todos, porque cada um vê o problema como sendo apenas dele. Porque os alunos são muito bons, regra geral em associar-se para determinados fins, mas não do ponto de vista, nem pedagógico, nem de coisas ligadas às questões quer de trabalhos, na pedagogia, quer na questão da investigação. E não é a questão da denúncia... é a questão de trabalhar para os outros no futuro não passarem por aquilo que eles passaram. Entretanto há aqui práticas que são características do nosso povo português... que é a individualidade nestas abordagens. Se se coordenassem em grupo e, de facto, fizessem uma exposição mais cooperante, as coisas teriam outros efeitos. Mas eu concordo contigo que, da nossa parte, existe um comportamento de... cobardia, por um lado... e de... não se querer comprometer com um problema que no final de contas é de todos. Mas as coisas tendem a mudar. Agora, é preciso que sejam umas mudanças que também ocorram do lado dos alunos e os alunos têm muito mais força que os docentes nessa parte.

Filipe Almeida: Vou só fazer um comentário ao comentário. Fazer a análise sistémica, do sistema... muito breve e superficial, em vez 
de falar de individuo. Por que é que os professores têm essa cobardia... e por que é que eles valorizam a prática fraudulenta do aluno? Por vários motivos... mas também... pelo menos... por um deles: a pressão sobre o professor incide essencialmente sobre a sua investigação e não sobre a sua vertente pedagógica. E nós estamos a falar de um assunto que é essencialmente relevante na vertente pedagógica da vida do professor. Mas quando o professor está na sala de aula, o que a instituição lhe cobra é a publicação de artigos... e a investigação... e eu não vejo as instituições igualmente preocupadas com o que se passa dentro da sala de aula. E o professor acaba por projetar essa desvalorização que a própria instituição porventura faz da vertente docente e projeta isso provavelmente na sua própria prática. E, porventura, fará a reflexão sobre... por que é que eu me vou desgastar com este assunto... se..., no fim do dia, o que me cobram é outro assunto que não consegui cumprir porque gastei o meu tempo e energia a tentar ser melhor professor e não melhor investigador. Isso é uma pressão dos tempos modernos e uma disfunção do sistema... porque todos reconhecemos que somos mais úteis à humanidade pelo contacto humano, dentro da sala de aula, do que pelo que escrevemos. Em média, alguns escrevem algumas coisas que transformam a humanidade... mas a maioria de nós terá uma maior oportunidade de deixar uma marca positiva pelo que faz dentro da sala de aula e não pelo que vai escrever. Mas a pressão é igual para todos e essa é uma das funções do sistema. Uma delas tem a ver com a passividade na instituição e com os sinais, porventura. Um professor que publica mas é mau professor dentro da sala de aula, em geral, tem uma carreira intocada e até elogiada. Um professor que é um excelente pedagogo e um transformador de consciências mas não publica tanto pode ter a sua carreira ameaçada. Esse é um dos problemas. Isto é a minha perspetiva que tenho 40 anos, portanto, vou a metade.

Aurora Castro Teixeira: Só uma pequena questão acerca disso. Isso é verdade mas está na consciência de cada um fazer o seu melhor. 
E da mesma forma como eu estava a dizer que os estudantes têm que se juntar para fazer valer aquilo que de facto é válido, também os professores devem-no fazer... nos sítios próprios. Ou seja, quando estamos a discutir nas nossas escolas sobre avaliação docente e sobre as componentes da avaliação docente, são os professores que decidem. Portanto, se são os professores que decidem, nós não podemos depois dizer que somos vítimas de uma coisa que decidimos, porque na prática, quando nós estamos a provar os diferentes sistemas, podemos ter, lá está, nós temos é comportamentos estratégicos, do estilo, portanto, vai ser mais fácil eu me afirmar por eventualmente publicar papers, porque isso é a quantidade e não a qualidade, porque nenhum júri, de saúde perfeita, consegue ler tanta coisa que a pessoa produz... vai apenas ao ISI e vai ver qual é o factor de impacto. Não interessa o que é que a pessoa escreveu, interessa onde publicou. E portanto apesar de admitirmos isso, nós somos reféns das decisões que nós tomámos. E portanto, ao contrário, às vezes, de muitos alunos que não têm essa hipótese, nós podíamos ter essa hipótese de fazer regulamentos que fossem mais... do estilo... vamos privilegiar a parte pedagógica e portanto, vamos, em vez de no regulamento ter $60 \%$ para a parte de investigação e $40 \%$ para a parte pedagógica, vamos fazer ao contrário. Mas da minha experiência isso não interessa. Ou seja, somos nós os primeiros a querer que o peso substancial esteja nessa parte da investigação, porque a outra... Eu, uma vez, estava num conselho científico e o presidente do científico disse-me, eu estava a dizer mal de um colega meu, pronto, não é muito ético, eu estava a dizer mal... Aurora, nós aqui somos todos bons professores. E eu, bem, estamos falados. Quando nós, nem é preciso estarmos dentro de uma sala de aula, para percebermos quem realmente faz a diferença perante os alunos... e eu não estou incluída aí, OK... e quem de facto se preocupa, e quem não faz diferença nenhuma. No entanto, para a maioria de nós é mais fácil ser avaliado por coisas mais objetivas do que ser avaliado pelos alunos. Aliás, 
da última alteração do regulamento de avaliação docente, simplesmente, na Universidade do Porto e na escola onde eu estou, a componente da avaliação dos alunos caiu; ou seja, já não entra para a avaliação docente, para nós percebermos como é que nós estamos. Mas quem é que decidiu isso? Nós.

Paulo Peixoto: Queria, enfim, justificar aquilo que vou dizer a seguir, dizendo.... duas coisas. Primeiro que é uma interpretação pessoal. E em segundo lugar que provavelmente no seio deste grupo, desta equipa, eu sou talvez o elemento das interpretações mais radicais, mais extremadas. Eu não vejo a questão dos abusos, em geral, na sociedade - e as diferentes formas de fraude académica e não académica são um tipo de abuso, mas poderemos falar dos abusos sexuais ou de outros tipos de abusos - não vejo, dizia, a questão dos abusos como uma questão que dependa do sexo, por exemplo. Nós podemos lê-las a partir da variável "sexo". Mas para mim a questão fundamental é sempre, neste caso, como em outros, a questão do poder... ou seja, na sociedade em que nós vivemos, os homens têm mais poder que as mulheres e portanto, eu vejo essa propensão dos homens, essa maior predisposição para a fraude, a partir dessa leitura do modo como o poder está distribuído. O próprio sentimento de impunidade está bem presente nos resultados. Ou seja, quem se sente mais impune, quem se sente mais protegido pelo poder que detem é quem tem... são os que têm mais recursos financeiros e sociais que têm maior propensão para a fraude. Aliás é curioso que a imprensa na última semana, pegou nesse dado mais do que nenhum outro, não é? E isso é relevante. É relevante, na minha perspetiva, que, num país como o nosso, em Portugal, não seja a fraude em si mesma que seja condenada mas... sobretudo as formas de fraude que não são democráticas. Ou seja, que não são acessíveis a toda a gente por igual. Ou seja, porque aquelas formas de fraude que são acessíveis a todos por igual, que os mais ricos e os mais pobres podem igualmente beneficiar, essas são socialmente 
mais exploradas. Portanto eu acho que essa é uma leitura incontornável, do meu ponto de vista, e que explica estas relações. Iria, às vezes, mais longe nesse meu radicalismo. Aquilo que o Filipe disse, ou seja, não estão aqui responsáveis institucionais das instituições de ensino superior, mas não é porque eles não saibam da existência deste estudo, não é porque eles não tenham sido convidados... é porque eles estão no poder e ao poder não lhe interessa discutir estas questões, desde logo. Na Alemanha, onde vários ministros perderam os seus diplomas por terem cometido fraude académica... é precisamente a exposição ao poder... a exposição que eles têm ao poder que os expõe enquanto alguém que teve comportamentos inadmissíveis... e nesse domínio, as instituições de ensino superior, sem querer aqui demonizar quem quer que seja, mas... há ocasiões onde isso deve ser falado e, no radicalismo que eu tenho muitas vezes em mim, eu tenho, particularmente neste contexto, a convicção que as instituições de ensino superior e os seus responsáveis não vivem num mundo à parte. Basta nós olharmos para aquilo que o regime jurídico das instituições de ensino superior fez nas instituições, que criou um novo órgão de governação nas instituições... e todas as instituições, sobretudo as maiores, as mais significativas em Portugal, colocaram... - o reitor não é mais a pessoa que formalmente tem o poder dentro das instituições... é o presidente do conselho geral, que é um membro externo - e todas elas colocaram homens do poder... banqueiros, não é? O ex presidente do BPI na Universidade de Coimbra, Santos Silva..., o Presidente do BPI, Fernando Ulrich, na Universidade do Algarve..., o... há pelo menos mais um... já me vou lembrar... o homem do Pingo Doce, na Universidade de Aveiro, o Presidente da Bial na Universidade do Porto e... em nenhum Conselho-Geral, ao longo do seu mandato, alguma vez estas universidades, que todas elaboraram planos estratégicos, que elaboraram as suas missões... as universidades não incluíram as questões da fraude nas suas agendas principais, nem nas grandes agendas, nem 
nas agendas do quotidiano. E a questão do poder, se virmos bem, ela é essencial para, quer nos pequenos comportamentos, quer nos comportamentos institucionais, ela é relevante. Quando entrei neste estudo... e estou muito, continuo muito nesta perspetiva... eu sempre tive e mantenho a esperança de poder transformar as instituições de ensino superior em Portugal no sentido de as ver desenvolver uma política integral de combate à fraude académica. Eu, enfim, algumas pessoas não sabem isso... eu estudei na Universidade de Lovaina, que foi o caso que nós trouxemos aqui para apresentar a sua política... fiz parte dos meus estudos aí... é um caso que venho acompanhando há algum tempo e que eu admiro enquanto política institucional e que eu gostaria de ver de alguma maneira adotado, aqui em Portugal, e penso hoje que, do ponto de vista da reflexão, temos muitas condições para o fazer. Agora, não vejo, do ponto de vista institucional, criadas as condições para que essas políticas possam ser desenvolvidas, não é? Portanto, acho isso... acho isso absolutamente relevante e olharmos para este módulo como a questão do poder, porque é essa questão do poder que depois nos faz ter aquelas desconfianças de que... se os médicos agem assim em contexto de formação, depois, como é que eles vão agir num contexto de exercício da profissão? E... sem estar aqui a enumerar, nós também sabemos que muitos dos casos da pequena e da grande corrupção da indústria farmacêutica à indústria médica, nestes anos, tem acontecido nessa área, não é? E portanto, uma sociedade que depois é o que é no seu quotidiano, terá muito pouco interesse em se transformar internamente e... e eu embora lendo as coisas com... embora lendo as coisas com, com esse pessimismo, continuo confiante de que é possível e desejável desenvolver políticas institucionais e acho que temos aqui bases para promover uma discussão que muito honestamente... eu sei que eu tenho que publicar... mas, para mim, tem muito mais impacto e muito mais relevância se quisermos discutir... uma questão que é fundamental, não só para a comunidade académica, para o país, para a sociedade 
em geral. Obviamente, a mim o que me vão perguntar no final, não é esse impacto... é outro impacto: é o fator de impacto. É uma fórmula que eu tenho na minha cabeça. Agora eu, pessoalmente, sinto-me muito mais realizado se de alguma maneira puder contribuir para essa discussão, para essa transformação. Agora, neste momento olho para isso com algum desconsolo mas não com desânimo, ao ponto de me sentir derrotado desde já.

Aurora Castro Teixeira: Há uma coisa que nós... portanto, tu focaste o caso alemão e os sucessivos escândalos. Mas há uma coisa que... a sociedade é importante. Ou seja, quando rebentou o primeiro escândalo em termos de fraude académica na Alemanha, todos os investigadores, ou uma grande parte dos investigadores, se insurgiram e assinaram uma petição para a demissão da pessoa. E portanto, houve uma mobilização social que eu... se o mesmo caso se passasse em Portugal, não existiria. A nossa sociedade, média, e nós próprios enquanto investigadores, nós não nos mobilizamos para essas causas, e, portanto, alguém que faça por nós mas... a causa é: a nossa sociedade é muito pouco interventiva para esse tipo de... se fosse um jogo de futebol, ou qualquer coisa assim... agora, para estar a mobilizar-se para alguém, isso eu não vejo... de facto somos muito pouco cívicos nessa componente. E nós somos uma sociedade baseada nos resultados e não nos processos. E isso é tão visível nas classes ditas mais altas... como nas mais baixas. Se nós formos a uma reunião de pais dos nossos filhos na escola, os pais em geral não querem saber se os filhos são bons alunos, maus alunos... se se portam bem ou não... o que querem saber é por que é que não tiraram tão boas notas como os outros, mesmo não estudando nada. E portanto, nós estamos sempre baseados nos resultados... seja... a esse nível... seja, ao nível das publicações... nós esquecemos o efeito aprendizagem, o efeito transmissão de conhecimento, a proximidade com os nossos pares. E é isso que acaba com o nosso modelo; ou melhor, se é que tínhamos algum modelo, e, portanto, essa base, não só de poder mas 
de um materialismo exagerado, de não olhar a meios para atingir fins, é isso que nos vai levar à ruína e que nos está a levar à ruína, em termos de sociedade. Agora, obviamente que isto é um discurso martirizante e fatalista... mas é o que está a acontecer. Cabe-nos a nós, por muito pequeno que seja o contributo, insistir, não desistir. OK, vamos... mesmo que os outros nos chamem demagogos, não temos nada para fazer na vida... mas é esse o nosso papel.

Luís Adriano Oliveira: A Professora Jude assumiu, numa troca de impressões que mantivemos num momento informal deste colóquio - naturalmente que estava a ter um discurso provocante, ou provocatório - mas... colocou uma questão perfeitamente legítima, colocada há pouco: OK, so what? Let's take action. Eu perguntei-lhe, de forma igualmente provocatória, então o que é que sugere? Quais seriam os seus passos? Vou reproduzir. O que ela estava a dizer, em termos de passos concretos, era que se constituísse uma comissão - não há português que quer que o problema se mantenha na mesma, que não constitua uma Comissão... não é nesse sentido que envolva uma percentagem suficientemente representativa de docentes dos vários departamentos da universidade. Mantenhamos para já, por exemplo, a nível de Coimbra, que envolva um conjunto representativo de alunos... e que... tome em consideração toda uma série de constatações que foram feitas, reflita sobre elas e proponha ação, com calendarização, no sentido de estabelecer ações de sensibilização, de alunos, de sensibilização de docentes, com um programa estabelecido, com, tipicamente, disse-me ela, sugeria, enfim... qualquer coisa como uma reunião de dois em dois meses! E digamos um horizonte temporal para apresentar conclusões... conclusões mas de ação, ativas, como por exemplo, eu estou a pensar na intervenção da Christelle, com ação efetiva que se possa depois traduzir no que ela mostrou... e, dizia ela, penso que com alguma lógica e legitimidade, nem sequer é preciso, neste momento, ser muito original. Porque há inúmeras universidades que estão nesse processo de forma mais ou 
menos avançada, mas estão nesse processo. Eu achei curioso este testemunho e esta provocação e... confesso que pegaria mais numa postura destas... embora ela seja relativamente vaga, reconheço, mas é, let's take action... mais do que propriamente ter... a postura, que compreendo perfeitamente, do colega Filipe Almeida, isto já não vai lá sem uma revolução estrutural. Porque essa revolução estrutural é provavelmente mais tentadora mas é também a solução mais arriscada... penso eu... e eu aderiria mais ao que disse o colega Paulo Peixoto: ainda não está tudo perdido, vamos ser positivos e vamos tentar take action. Só dizer uma outra coisa, muito pequena: nós temos na engenharia mecânica um núcleo de estudantes que é o NEMAC, que organiza regularmente, com uma periodicidade anual, semestral... umas jornadas pedagógicas... e as jornadas pedagógicas são levadas muito a sério, são muito participadas pelos alunos, que são capazes de encher um auditório pouco mais pequeno do que este e também conseguem mobilizar, não tanto os docentes mas muitos discentes, sobretudo aqueles que se interessam mais pela componente didática. E os alunos aí exprimem-se, com slides... exprimem-se sem grandes inibições... batem a sério... porque eles próprios fazem inquéritos internos, não são só os inquéritos oficiais mas também tomam naturalmente em consideração esses inquéritos, mas depois fazem uma análise muito objetiva, muito desinibida sobre as consequências e as conclusões que eles próprios tiram desses inquéritos, e criticam frontalmente os professores. O que é interessante depois, é que os professores, e eu sou conhecido por isso, criticam frontalmente os alunos. Eu não tenho inibição nenhuma de criticar frontalmente os alunos. Devo dizer que aqui em Coimbra há um grande hábito de boémia e uma grande falta de hábito de trabalho. A cultura de trabalho de Coimbra tem uma imagem de boémia, isso paga-se. Quando se diz que há uma carga enorme de trabalho... reconheço que exista e provavelmente advem até do que resulta da implementação da reforma de Bolonha... mas... se houvesse uma cultura de 
trabalho, penso que muita coisa poderia ser ultrapassada. Digo isso nas jornadas pedagógicas... mas, tudo isto para referir apenas que, o núcleo de estudantes de engenharia mecânica dinamiza reflexões que têm consequências práticas. No dia seguinte está toda a gente, no pequeno almoço, a discutir o que é que se passou nas jornadas pedagógicas e portanto isto implica ação concreta e eu julgo que se núcleos de estudantes fossem envolvidos na implementação de medidas que possam decorrer de conclusões tiradas de iniciativas nobilíssimas como estas, provavelmente teríamos uma cumplicidade muito importante desse tecido, que é fundamental, que são os estudantes.

Filipe Almeida: Não vamos perpetuar aqui o nosso encontro mas, em todo o caso, pergunto-me em silêncio, sem querer provocá-lo, como se não dissesse nada da boca para fora, se essas jornadas pedagógicas e outras iniciativas, não essa em particular, mas iniciativas como essas não são muitas vezes uma válvula de escape do sistema, que permite que ele se legitime e perpetue? Em relação ao facto de eu pensar que estamos no fim de um tempo, é fruto do meu profundíssimo optimismo. Profundíssimo optimismo. Porque para mim, é muito mais desgraçada a visão de que isto se vai perpetuar e apodrecer devagarinho ou melhorar devagar. $O$ optimismo de que o fim de um tempo é o princípio de outro que seja melhor. E, hoje em dia, estou mais convencido de que... uma ruptura disruptiva, passe a redundância, pode funcionar melhor. E essa disrupção pode ser, por exemplo, uma instituição de referência, inteira e de uma só vez, modificar a forma como atua, e isso pode ser radical e contagiante. Não antecipo detalhes mas é esse tipo de revolução de que estou a falar. Depois o modelo será outro, mas... perpetuar este com pequenas conjunções missionadas não me convence. Apesar da idade, tenho vindo a perder a fé numa certa dimensão da natureza humana, o que é bom, o que é bom. Vejo tudo isto de uma forma positiva. 
Aurora Castro Teixeira: Eu queria dizer: eu sou contra as Comissões. Começa logo por aí. Não acho que resultem, no caso concreto, na nossa cultura... sou totalmente favorável à questão bottom-up. Têm que ser as bases... mas as bases não têm que ser envolvidas, elas têm que se envolver, que é uma coisa diferente. Quando nós estamos a dizer, nós temos que fazer os alunos... eu acho que é exatamente os alunos que têm que trazer essa mudança e têm que envolver depois as bases acima e é nisso que também no nosso sistema, quando nós ouvimos falar da... dos códigos de conduta... eu estive presente num colóquio internacional de fraude e os colegas norte-americanos estavam a dizer que nos códigos de conduta e na formulação só os alunos é que entram. Não há aqui docentes... São geridos pelos próprios estudantes e são geridos pelas comunidades de estudantes. Depois podem ser chamados os docentes, como é óbvio que são, dado serem pessoas que estão intimamente envolvidas. Mas a base está precisamente em serem os estudantes os primeiros interessados em que o sistema seja... e portanto... muitas vezes nós temos essa atitude um bocado paternalista de... vamos envolver os estudantes... não... são eles que têm que criar essa geração de mudança e são eles que têm que se envolver. E é porque não se envolvem que muitas vezes nós estamos sempre nestas... e claro que cada um de nós... eu obviamente... nem tanto radical, nesta questão da disruptiva, mas eu defendo que... eu tenho a ideia romântica de que eu vou mudar o mundo e, portanto, eu nunca vou fazer grandes coisas bem. Mas posso fazer pequeninas coisas com grandeza e começo a atuar naquilo que eu posso atuar, que é a minha sala de aulas, que é a minha relação com os meus orientandos e... tento esperar que através desses exemplos, que as coisas também se possam encaminhar. E, por isso, sempre que eu tenho oportunidade, tento abanar as estruturas. Mas, dada a minha dimensão, a maior parte das vezes ignoram-me. Mas... eu tenho a profunda convicção que os estudantes, querendo e estando motivados, podem fazer essa mudança. E que 
não vai mudar... aí concordo com o Filipe que, dada a dimensão que isto... nomeadamente no $2^{\circ}$ ciclo alcançou, por força do sistema de Bolonha, os estudantes estão a sentir-se altamente injustiçados na forma como são tratados, como... as coisa estão a... e não vai... e, portanto, dada a massa de estudantes que está envolvida, o sistema vai implodir em pouco tempo, pelo menos naquilo que eu presencio. Portanto, eu também sou optimista nessa coisa da revolução, mas acho também que a sociedade e os estudantes em particular e nós docentes também, teremos que ser muito mais ativos do ponto de vista social, esquecendo um bocadinho a questão dos resultados, e eu estou a fazer isto porquê? porque isto me vai criar um incentivo, porque alguém vai reconhecer mais? Não, nós temos que fazer isto porque isto vale a pena fazer para mudar a sociedade para melhor. Não é porque eu vou ficar melhor do ponto de vista profissional... aí concordo com o Paulo. Eu vou ficar melhor do ponto de vista pessoal, sim. Porque o mundo vai ficar melhor. E não estou a ser nada utópica.

Coimbra, 9 de maio de 2014 
(Página deixada propositadamente em branco.) 
Filipe Almeida é docente da FEUC e investigador do Centro de Estudos Sociais e do Centro de Estudos Cooperativos e da Economia Social. É doutor em Administração pela EBAPE/FGV (Escola Brasileira de Administração Pública e de Empresas da Fundação Getúlio Vargas, Rio de Janeiro, Brasil) e doutor em Gestão de Empresas pela FEUC. É também mestre em Ciências Empresariais pela FEUC, tendo frequentado o programa de MBA na Virginia Polytechnic Institute and State University (EUA). É autor, entre outros, dos livros "Ética, Valores Humanos e Responsabilidade Social das Empresas" (Princípia, 2010) e "Organizações, Pessoas e Novas Tecnologias" (Quarteto Editora, 2002).

Ana Maria Seixas é doutorada em Ciências da Educação, área de especialização de Sociologia da Educação, pela Universidade de Coimbra. É professora auxiliar da Faculdade de Psicologia e de Ciências da Educação, onde exerce funções docentes desde 1987. É também investigadora no Centro de Estudos Sociais, onde integra o Núcleo de Políticas Sociais, Trabalho e Desigualdades e o Observatório das Políticas de Educação e Formação. Tem várias publicações nos domínios da sociologia da educação, ensino superior, educação comparada e políticas educativas.

Paulo Gama é doutorado em Gestão na especialidade de Finanças pelo ISCTE-IUL. Licenciado em Economia (Universidade de Coimbra) e Mestre em Ciências Empresariais (ISCTE-IUL). Ingressou na FEUC em 1992, onde tem lecionado unidades curriculares na área das finanças empresariais e mercados financeiros. Os seus interesses de investigação centram-se nos mercados de capitais internacionais e na relação entre características das empresas, incluindo PMEs, e desempenho. É co-autor do Manual de Gestão Financeira Empresarial e tem várias publicações em revistas internacionais.

Paulo Peixoto é doutorado em Sociologia pela Universidade de Coimbra e é investigador do Centro de Estudos Sociais.

É professor de Sociologia na Faculdade de Economia da Universidade de Coimbra. Integra o Grupo de Pesquisa Arte, Cultura e Poder (CNPq/UERJ) na Universidade Estadual do Rio de Janeiro, onde foi Professor visitante. Executa atualmente projetos de investigação sobre património e turismo e sobre ensino superior. Desenvolve atividades de extensão coordenando a avaliação de projetos de intervenção social e de políticas públicas.

Denise Esteves é licenciada em Antropologia e mestre em Sociologia pela Universidade de Coimbra. Tem integrado projetos de investigação científica sobre educação e sucesso académico, políticas educativas, ensino superior e avaliação internacional de adultos (PIACC- OECD) nas universidades do Porto, Coimbra e CIES-ISCTE em Lisboa. Foi investigadora do projeto "A ética dos alunos e a tolerância de professores e instituições perante a fraude académica no ensino superior", desenvolvido pelo CES. 
Série Investigação

Imprensa da Universidade de Coimbra

Coimbra University Press

2016

OBRA PUBLICADA

COM A COORDENAÇÃO

CIENTÍFICA

$P_{\text {ces }}$

Centro de Estudos Sociais

Laboratório Associado

Universidade de Coimbra

FCT

Fundação para a Ciência e a Tecnologia

\section{COMPETE}

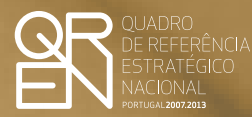

UNIĀO EUROPEIA UNIAO EUROPEIA 